\title{
A QUESTÃO AGRÁRIA NO BRASIL
}

CAMPESINATO, AGRICULTURA FAMILIAR E AGRONEGÓCIO
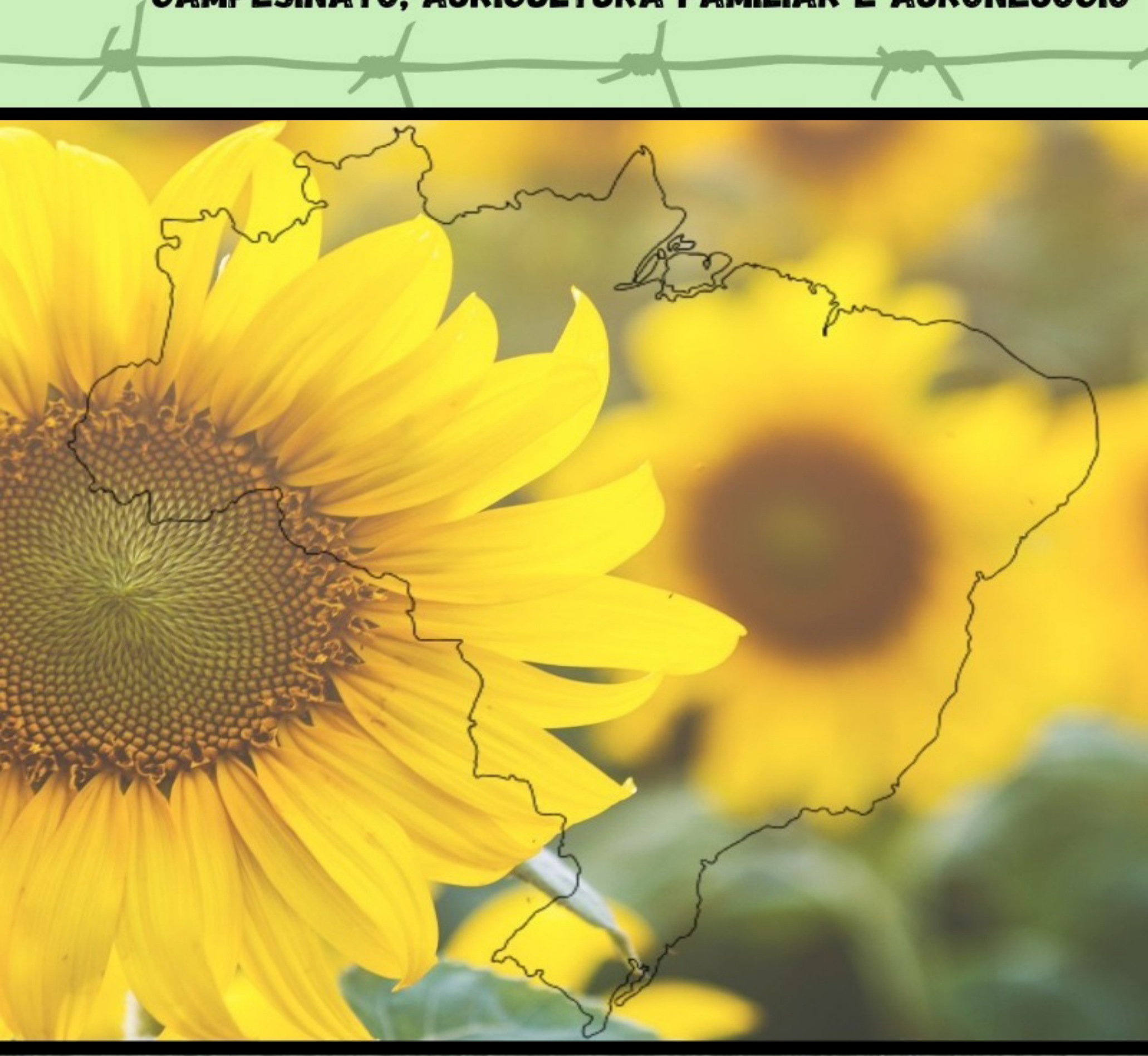

Adilson Tadeu Basquerote Silva

Ane Carine Meurer

Eduardo Pimentel Menezes

[Organizadores]

$A R<2$

EDITORES 


\section{A QUESTÃO AGRÁRIA NO BRASIL}

CAMPESINATO, AGRICULTURA FAMILIAR E AGRONEGÓCIO
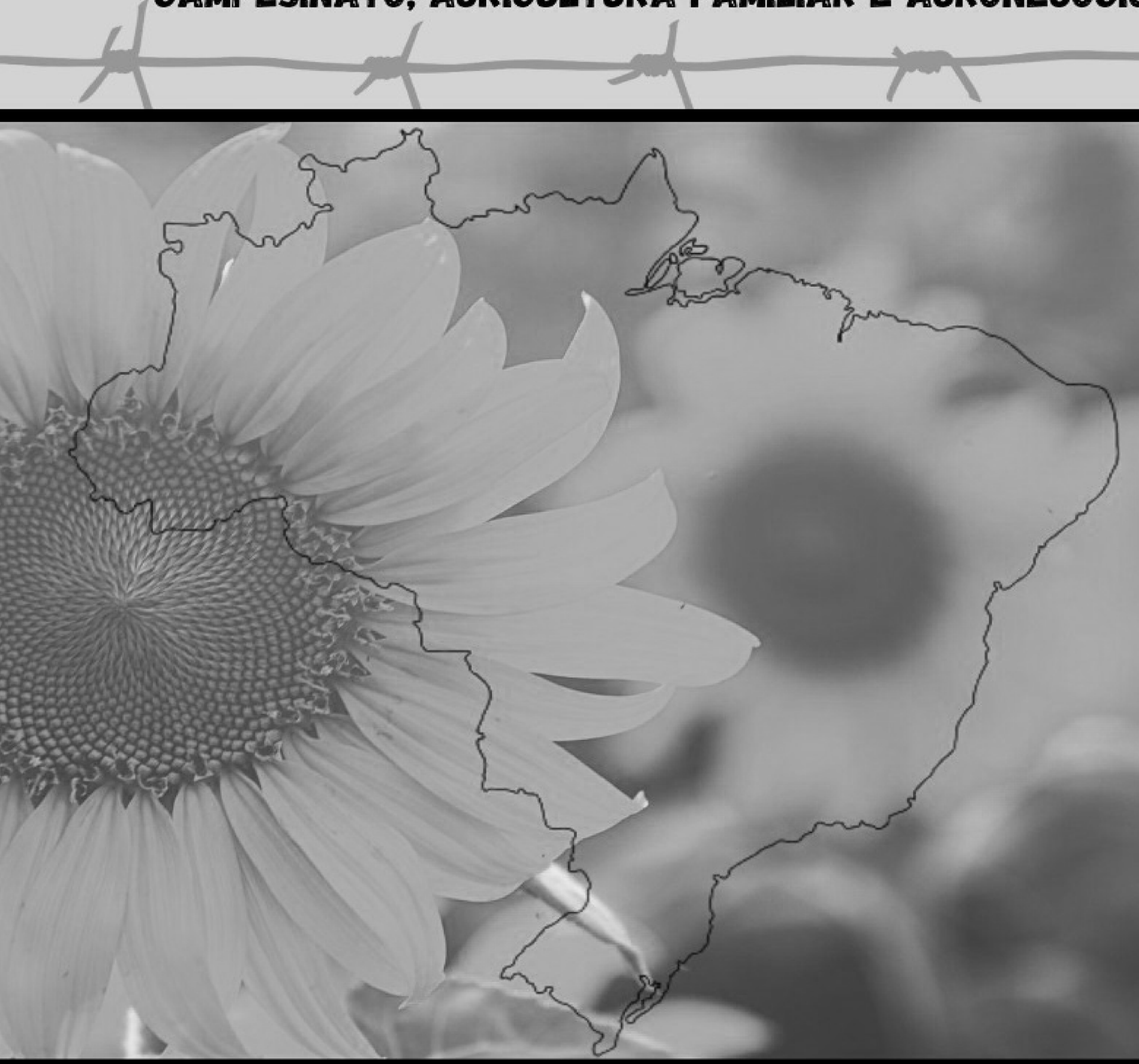

Adilson Tadeu Basquerote Silva

Ane Carine Meurer

Eduardo Pimentel Menezes

[organizaideres]

A $\mathrm{C} Q$

EDITORES 


\section{CONSELHO EDITORIAL}

Prof. Dr. Adilson Tadeu Basquerote

Silva

UNIDAVI/SC

http://lattes.cnpq.br/8318350738705473

Profa. Msc. Jesica Wendy Beltrán

UFCE- Colômbia

http://lattes.cnpq.br/0048679279914457

Profa. Dra Fabiane dos Santos Ramos UFSM- Santa Maria/RS

http://lattes.cnpq.br/0003382878348789

Dr. João Riél Manuel Nunes Vieira de Oliveira Brito

UAL - Lisboa- Portugal.

http://lattes.cnpq.br/1347367542944960

Profa. Dra. Alessandra Regina Müller Germani

UFFS- Passo Fundo/RS

http://lattes.cnpq.br/7956662371295912

Prof. Dr. Everton Bandeira Martins

UFFS - Chapecó/SC

http://lattes.cnpq.br/9818548065077031

Prof. Dr. Erick Kader Callegaro Corrêa UFN- Santa Maria/RS

http://lattes.cnpq.br/2363988112549627

Prof. Dr. Pedro Henrique Witchs

UFES - Vitória/ES

http://lattes.cnpq.br/3913436849859138

Prof. Dr.Thiago Ribeiro Rafagnin

UFOB

http://lattes.cnpq.br/3377502960363268
Prof. Dr. Mateus Henrique Köhler

UFSM- Santa Maria/RS

http://lattes.cnpq.br/5754140057757003

Profa. Dra. Liziany Müller Medeiros

UFSM- Santa Maria/RS

http://lattes.cnpq.br/1486004582806497

Prof. Dr. Camilo Darsie de Souza

UNISC- Santa Cruz do Sul/RS

http://lattes.cnpq.br/4407126331414

Prof. Dr. Dioni Paulo Pastorio

UFRGS - Porto Alegre/RS

http://lattes.cnpq.br/7823646075456872

Prof. Dr. Leonardo Bigolin Jantsch

UFSM- Palmeira das Missões/RS

http://lattes.cnpq.br/0639803965762459

Prof. Dr. Leandro Antônio dos Santos

UFU- Uberlândia/MG

http://lattes.cnpq.br/4649031713685124

Dr. Rafael Nogueira Furtado

UFJF- Juiz de Fora/MG

http://lattes.cnpq.br/9761786872182217

Profa. Dra. Angelita Zimmermann

UFSM- Santa Maria/RS

http://lattes.cnpq.br/7548796037921237

Profa. Dra. Francielle Benini Agne

Tybusch

UFN - Santa Maria/RS

http://lattes.cnpq.br/4400702817251869

Copyright (c) Arco Editora, alguns direitos reservados.

Copyright do texto (C) 2022 os autores e as autoras.

Copyright da edição ( 2022 Arco Editora. 
Diagramação e Projeto Gráfico : Gabriel Eldereti Machado

Imagen capa: www.freepik.com

Revisão: dos/as autores/as.

Dados Internacionais de Catalogação na Publicação (CIP) (Câmara Brasileira do Livro, SP, Brasil)

A questão agrária no Brasil [livro eletrônico] : campesinato, agricultura familiar e agronegócio / organização Adilson Tadeu Basquerote, Ane Carine Meurer, Eduardo Pimentel Menezes. -- Santa Maria, RS : Arco Editores, 2022. PDF.

\section{Bibliografia.}

ISBN 978-65-89949-59-6

1. Agricultura familiar 2. Agronegócio Brasil 3. Campesinato - Brasil 4. Ciências agrárias I. Basquerote, Adilson Tadeu. II. Meurer, Ane Carine. III. Menezes, Eduardo Pimentel.

$22-97723$ CDD -630

Índices para catálogo sistemático:

1. Ciências agrárias 630

Aline Graziele Benitez - Bibliotecária - CRB-1/3129 dol $10.48209 / 978-65-89949-59-6$

O padrão linguístico-gramatical, bem como o sistema de citações e referências bibliográficas são prerrogativas de cada autor. Da mesma maneira, o conteúdo e teor de cada capítulo é de inteira e exclusiva responsabilidade de seu respectivo autor. 


\section{APRESENTAÇÃO}

A questão agrária pode ser compreendida como um termo, uma temática ou um conceito (amplamente discutido no meio acadêmico brasileiro). Nesse livro, iremos tratá-lo como conceito e nele, foram reunidas várias áreas do conhecimento para tornar estava tonar sua leitura, o mais interdisciplinar possível. Nele, apresentamos conotações que possuem relação direta com o que acreditamos, com as experiências que temos, com as leituras que fazemos e, entre outras questões, com a capacidade que possuímos de descentrar a nossa reflexão do imediato e do vivido, ampliando o universo temático ou conceitual. No Brasil, o cenário agrário diz respeito a uma problemática que se articula a partir da disputa do território nacional mediado por distintos interesses, entre eles: dos camponeses (pois refere-se a sua vinculação a terra e a sua reprodução), do capital transnacional (detém o capital agrário, industrial e financeiro (bancos, fundos de investimento e pensão, ou empresa que recebe a matéria prima produzida na terra e a transforma, laboratórios, engenharia genética e tecnológica) ou dos proprietários de grandes extensões de terra (concentram grandes quantidades de terra promovendo e ampliando a concentração e expansão dos monocultivos de commodities). Segundo Stedile (2012, p. 641) ${ }^{1}$, a questão agrária refere-se ao "[...] uso, a posse e a propriedade da terra [...].

Sobre o exposto, é importante questionarmos se e como, o nosso país tem possibilitado por meio de políticas públicas, o acesso à terra, ou seja, para quem, como, quando, que produtos serão produzidos, seus impactos na natureza (implicações ambientais, na água, no solo, das florestas, do mar, entre outros), e nas pessoas (consumidores e trabalhadores do campo e da cidade). Envolvem-se aí, também as questões relacionadas a soberania e segurança alimentar. Entre os questionamentos que a temática nos promove, refletimos sobre: Quem são as pessoas que vivem nas terras agrícolas brasileiras? Como chegaram até elas?

1 STEDILE, João Pedro, Questão Agrária. In. CALDART, Roseli Salete et al. Dicionário da Educação do Campo. Rio de Janeiro, São Paulo: Escola Politécnica de Saúde Joaquim Venâncio, Expressão Popular, 2012. 
Em que aspectos a legislação brasileira privilegia e possibilita a quem o acesso à terra?

De antemão, afirmamos que o Brasil apresenta aspectos históricos e espaciais que revelam a construção de consensos sobre essa questão, determinando quem teve, quem têm e quem poderá usar, ter a posse e a propriedade da terra em nosso país. Esse aspecto, também possui íntima relação com quem os construiu, com os interesses que se explicitam na sua elaboração. Nesse sentido, temos participado de discussões que analisam a questão agrária brasileira a partir de dois consensos, elaborados e sistematizados por Fernandes $(2013)^{2}$ e que se apresentam a partir do paradigma da questão agrária e do capitalismo agrário. Será no cenário das discussões críticas relacionadas ao paradigma da questão agrária que se inseriram os vários autores que contribuíram com a escrita dessa obra. Contudo, com esse esclarecimento, não queremos organizar um novo consenso, e sim, fazer o que nos cabe como pesquisadores da área: trazer uma outra perspectiva sobre o que é hegemônico. Com efeito, apresentamos questões culturais e educacionais, que nos possibilitam refletir sobre a temática agrária em nosso país, da forma como a temos, ao pensar o uso, a posse e a propriedade da terra. Nessa perspectiva, devemos entendê-la como uma política pública que inclui camponeses Sem Terra, pequenos produtores de orgânicos, quilombolas, indígenas ou deve priorizar apenas os grandes empreendimentos e o agronegócio? Questionar sobre essa cultura e educação, é pensar na perspectiva ideológica que organiza a nossa forma de estruturar a nossa racionalidade.

Destacamos a necessidade de apresentar os conceitos discutidos na obra: o campesinato, a agricultura familiar e o agronegócio. O primeiro, refere-se a modos de vida, formas, normas desenvolvidas por famílias camponesas ao se relacionarem com o território, com a terra, com o ambiente, com a cultura, com o patrimônio, com a educação, com a economia, com os modos de produção e de

2 FERNANDES, Bernardo Mançano. Construindo um estilo de pensamento na questão agrária: o debate paradigmático e o conhecimento geográfico. 2013. 873f. Tese (Livre-docência) - Universidade Estadual Paulista Júlio de Mesquita Filho, Faculdade Ciências e Tecnologia, 2013. Disponível em: <http://hdl.handle.net/11449/106708>. Acesso em: 14 dez. 2021. 
consumo relacionados a sua reprodução. Articula-se aí a interculturalidade, por meio da formação das novas gerações, a partir de trocas estabelecidas e que garantam que os descendentes acessem os conhecimentos ancestrais (modos de fazer, modos de consumir, modos de ser, modos de se relacionar, em grande parte não capitalistas). Historicamente o campesinato, que varia na sua forma de organização de acordo com a sociedade em que se estabelece, procura construir uma identidade social, afirmando-se como classe social e apresenta-se na relação com os demais personagens (agricultores familiares e agronegócio) na disputa do território. Procura nas relações que estabelece, reproduzir-se e garantir a manutenção da segurança e soberania alimentar. Nesse sentido, são desenvolvidos vários aspectos relacionados a sua reprodução e articulação.

Os campesinos organizam-se a partir da terra, sua referência e segurança a partir da terra, sua referência e segurança. Em contexto semelhante, a denominação, agricultura familiar, tem relação com camponeses, que não necessariamente se organizam coletivamente, assim como no campesinato, mas vivem na e da terra, vendendo o excedente. Constituem-se em torno do estabelecimento rural familiar e se reproduzem, preponderantemente, a partir do trabalho familiar, desenvolvendo relação particular com a terra, seu local de trabalho e moradia. De modo geral, a gestão da propriedade é partilhada pela família e a agropecuária compõe a principal fonte geradora de renda. A diversidade produtiva também é uma característica marcante desse setor, pois muitas vezes alia a produção de subsistência a uma produção destinada ao mercado. No Brasil, a primeira política pública que contemplou a agricultura familiar, foi o Programa Nacional de Fortalecimento da Agricultura Familiar (PRONAF) no ano de 1996, no Governo

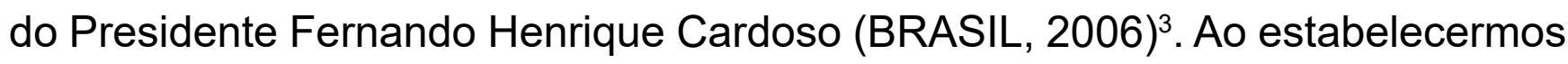
uma relação entre campesinato e agricultura familiar, podemos entender que na história da agricultura, eles se fundiam. No entanto, na atualidade, muitas nuan-

3 BRASIL. Lei 11.326, de 24 de julho de 2006. Estabelece as diretrizes para a formulação da Política Nacional da Agricultura Familiar e Empreendimentos Familiares Rurais. Diário Oficial da União, dia 25 de julho de 2006. 
ces precisariam ser analisadas para encontrarmos convergências. Portanto, é fundamental que as análises continuem sendo feitas com os sujeitos envolvidos, a fim de que não fiquemos idealizando projetos. Quanto ao conceito Agronegócio, é possível afirmar que o mesmo sofreu variações no decorrer da história do Brasil.

É importante ressaltar que as mudanças sempre estiveram diretamente vinculadas com questões econômicas, políticas, relações de trabalho, propriedade da terra, ambientais, entre outras. Nesse sentido, destacaremos a relação patrão e empregado, em que trabalhadores permanentes e temporários, por vezes são desassistidos de direitos trabalhistas, ou encontram-se em situação análoga à escravidão em algumas regiões do país.

Além do exposto, destacamos que no Agronegócio persiste a tendência de ampliar o controle de áreas produtivas, das sementes, da indústria química (biotecnologia), indústria mecânica e tecnológica (agricultura de precisão, monitoramento por satélite, entre outros.) e articular a produção em larga escala, a fim de honrar com contratos internacionais entre empresas estrangeiras produtoras dos insumos ou empresas agroindustriais, que controlam o armazenamento, beneficiamento e venda de sementes.

Ressaltamos que a maioria da produção de grãos, reconhecidos como commodities agrícolas, são exportados do Brasil sem nenhum beneficiamento, denotando assim, menor valor agregado. Nessa direção, o modelo agroexportador possui a necessidade de ampliar sua área de produção de maneira exponencial, promovendo devastação tanto em pequenas propriedades como nas florestas. Soma-se a isso, os conglomerados multinacionais com ou sem implicações com a agricultura, articulam-se as instituições financeiras que promovem uma outra organização econômica em nível transnacional. Por outro lado, em grande medida, o Estado Brasileiro, por meio de parcerias e concessões, fornece a infraestrutura para que o capital se reproduza, gerando mais riqueza para poucos 
em detrimento da exploração do trabalhador, seu adoecimento pela exposição a defensivos agrícolas (agrotóxicos) e ou jornadas extenuantes.

Em outra direção, embora haja contradições e embates, existem distintas experiências que visam uma outra forma de viver e estar no campo. Nelas para quem consegue, no encontro com o outro oprimido, reconhecer-se e solidarizar-se, encontra forças para resistir e manter o foco em um outro projeto de sociedade. Nessa direção, essa obra se apresenta como uma forma de resistência, que denuncia interpretações equivocadas e legislações descumpridas. Além disso, ela compreende que a mídia, as redes sociais e demais formas de organização e manipulação da comunicação, são usados para ludibriar e gerar falsas interpretações da realidade.

Ademais, denuncia a desigualdade, a dificuldade de organização, e ausência de educação de qualidade, que nos leva a sermos subordinados à cultura do opressor, como destaca Paulo Freire ${ }^{4}$. Ainda identifica o quanto teremos que continuar mobilizados para que os direitos e garantias fundamentais do povo sejam assegurados. Destaca a importância dos movimentos referentes ao esperançar, quando intelectuais orgânicos se formam através da ação e resistência dos movimentos sociais, quando os professores se transformam e efetivam projetos político-pedagógicos de escola, que se articulam com um outro projeto de sociedade. Por fim, referenda um movimento que necessita prosseguir e nessa direção, nós organizadores estendemos o convite a todos vocês para apreciarem a obra. Agradecemos e desejamos uma excelente leitura!

Dr. Adilson Tadeu Basquerote

Dra. Ane Carine Meurer

Dr. Eduardo Pimentel Menezes

4 FREIRE, Paulo. Pedagogia do Oprimido. 54. ed.rev.e atual. Rio de Janeiro: Paz e Terra, 2013. 


\section{SUMÁRIO}

\section{CAPÍTULO 1}

MINERAÇÃO, IMPACTOS SOCIOCULTURAIS E A RESISTÊNCIA DE COMUNIDADES QUILOMBOLAS A PARTIR DOS CONHECIMENTOS TRADICIONAIS E SOCIOAMBIENTAIS.

Antonio Eusébio de Sousa

doi: 10.48209/978-QR-89949-01-6

\section{CAPÍTULO 2}

A FALÁCIA DO DISCURSO DE MODERNIZAÇÃO NO CAMPO E A APROPRIAÇÃO DA TERRA E DA ÁGUA PELO CAPITAL NO PLATÔ DE NEÓPOLIS - SE. .28

Mara Íris Barreto Lima

Josefa de Lisboa Santos

Bruno Andrade Ribeiro

doi: 10.48209/978-QR-89949-02-6

\section{CAPÍTULO 3}

ESPAÇO AGRÁRIO, ASSENTAMENTO DO INCRA E PECUÁRIA: SE NÃO ERA PARA SER FAZENDA, TORNOU-SE FAZENDA DO MESMO JEITO .46

Mílvio da Silva Ribeiro

João Santos Nahum

doi: 10.48209/978-QR-89949-03-6

\section{CAPÍTULO 4}

NOTAS SOBRE O AGRONEGÓCIO DA PIMENTA EM SERGIPE: TERRA E TRABALHO SOB DOMINAÇÃO DO CAPITAL........................................65

Tiago Barreto Lima

Josefa de Lisboa Santos

Bruno Andrade Ribeiro

doi: 10.48209/978-QR-89949-04-6 


\section{CAPÍTULO 5}

FORMAÇÃO DE DOCENTES DA EDUCAÇÃO DO CAMPO: CONSIDERAÇÕES SOBRE AS EXPERIÊNCIAS DO CEGEO/PRONERA E DA LEDUC/PROCAMPO. .84

Rodrigo Simão Camacho

doi: 10.48209/978-QR-89949-05-6

\section{CAPÍTULO 6}

A ATUAÇÃO dAS CENTRAIS DE ABASTECIMENTO E DAS COOPERATIVAS NA COMERCIALIZAÇÃO DE PRODUTOS AGRÍCOLAS NO BRASIL

Larissa Oliveira Dionisio

Antonio Nivaldo Hespanhol

doi: 10.48209/978-QR-89949-06-6

\section{CAPÍTULO 7}

A COMPOSIÇÃO SOCIOESPACIAL DAS COMUNIDADES QUILOMBOLAS DE GARANHUNS E O SEU PROCESSO DE DELIMITAÇÃO TERRITORIAL

Wellington Cesar Barbosa de Lira

doi: 10.48209/978-QR-89949-07-6

\section{CAPÍTULO 8}

DENDEICULTURA E TRANSFORMAÇÃO DA PAISAGEM RURAL NA MICRORREGIÃO DE TOMÉ-AÇU.

Leonardo de Sousa Santos

João Santos Nahum

doi: 10.48209/978-QR-89949-08-6

\section{CAPÍTULO 9}

A CESTA AGROECOLÓGICA CAMPO CIDADE (CURITIBA/PR) E A CONSTRUÇÃO DE TERRITÓRIOS AGROECOLÓGICOS....................150

Nathalie Vieira Lucion

doi: 10.48209/978-QR-89949-09-6 


\section{CAPÍTULO 10}

DO CONSUMO SELETIVO À NECESSIDADE DE UNIVERSALIZAÇÃO DOS PRODUTOS ORGÂNICOS. 166

Geovânio Silva Santos

Josefa de Lisboa Santos

Tiago Barreto Lima

doi: 10.48209/978-QR-89949-10-6

\section{CAPÍTULO 11}

TRANSFORMANDO A TERRA EM HORTA ESCOLAR: A APLICAÇÃO DOS SABERES DOS JOVENS DO CAMPO NA ESCOLA ESTADUAL JOSÉ DE MATOS TELES EM JAPARATUBA- SERGIPE 185

Handresha da Rocha Santos

Hádrian George da Rocha Santos

doi: 10.48209/978-QR-89949-11-6

\section{CAPÍTULO 12}

TERRAS DEVOLUTAS E DISCRICIONARIEDADE ADMINISTRATIVA: ANÁLISE CRÍTICA DA SUPREMACIA DO INTERESSE PÚBLICO SOBRE O PRIVADO A LUZ DO CONSTITUCIONALISMO CONTEMPORÂNEO 197

Walder Araújo de Oliveira doi: 10.48209/978-QR-89949-12-6

SOBRE OS ORGANIZADORES 215 
dol 10.48209/978-QR-89949-01-6

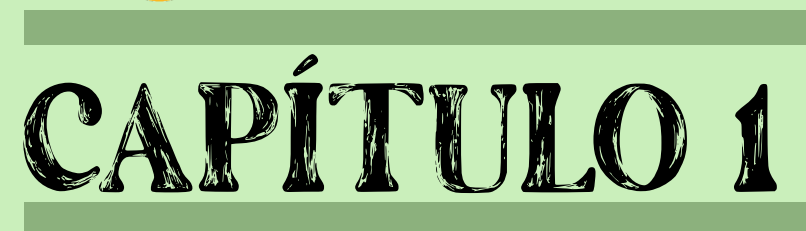

MINERAÇÃO, IMPACTOS SOCIOCULTURAIS E A RESISTÊNCIA DE COMUNIDADES QUILOMBOLAS A PARTIR DOS CONHECIMENTOS TRADICIONAIS E SOCIOAMBIENTAIS

Antonio Eusébio de Sousa 


\section{INTRODUÇÃO}

Historicamente, as comunidades rurais principalmente no semiárido foram vistas como lugar do atraso e, ao mesmo tempo, o espaço para o enriquecimento de outros povos. Tal fato foi se constituindo num espaço de dificuldade de as pessoas irem se afirmando como categoria própria. Isso está associado ao desenvolvimento do Estado brasileiro, que teve como pressuposto ser o único caminho para o conjunto da sociedade, a modernização pregando o mito do progresso, algo que no semiárido piauiense não é diferente.

Para a realização da proposta de desenvolvimento, o Estado do Piauí em parceria com um conjunto de empresas vem buscando instalar projetos do capital em diversos espaços, como foco para essa analise as relações entre os referidos projetos e as comunidades quilombolas, dessa forma foram surgindo um conjunto de contradições visto que se trata de comunidades protegidas pelos dispositivos legais.

Importante destacar que o governo do Estado vendeu a propaganda de uma região pobre atrasada que dispõe de grande potencial a ser explorado, necessitando de grandes empresas nacionais e internacionais, tal propaganda ou acordos foram sendo construído sem que as comunidades sejam consultadas que tipo de desenvolvimento as mesmas preferiam naquele período, sendo o único instrumento utilizado a audiência pública sendo realizada fora do município em que as famílias vivem, dificultando a participação dos mesmos.

Apresenta como discussão nesse estudo as contradições existente entre o projeto de mineração Massapê - Manga Velha, com pesquisa já realizada e catalogada pela Empresa Brasil Mineral S/A - BEMISA vinculado ao macroprojeto Planalto Piauí e as comunidades quilombolas Caititu e São Martins, somam nessa disputa os problemas enfrentados junto a implantação da ferrovia transnordentina onde a construção do trecho na região antecede o projeto em debate. 
O que se percebe nesse modelo em fase de implantação, são os desrespeitos aos conhecimentos tradicionais, porém, associado a tal fato, surge a resistência e a afirmação por parte das comunidades.

Os exemplos de resistência e as formas como as comunidades se afirmam como comunidades tradicionais, permite compreender que é baseado na cultura e nos fundamentos teológicos, que permite o cuidado como a natureza e com a vida humana e animal se constituem.

A pesquisa consistiu em aproximar o conhecimento tradicional do conhecimento acadêmico, a fim de reforçar a categoria de cada comunidade e contribuir para o fortalecimento de uma consciência sociocultural. Esse trabalho está estruturado em três partes. A primeira traz uma abordagem sobre mineração e impactos socioterritoriais, a segunda apresenta uma discussão sobre comunidades tradicionais quilombolas conhecimentos tradicionais e suas relações com a natureza e por último apresenta o resultado da pesquisa a partir dos exemplos de resistência das comunidades quilombolas Caititu e São Martins.

\section{DESENVOLVIMENTO}

A história da exploração mineral no Brasil começa praticamente junto com a chegada dos colonizadores. Os portugueses estavam interessados especialmente no ouro. A cobiça dos colonizadores foi intensa e insaciável. Pela busca de riquezas, devastavam o que encontravam pela frente e, ao mesmo tempo, escravizavam e exterminavam os povos indígenas, sem respeitar limites para tal exploração.

Nos últimos anos, o governo brasileiro elaborou o que foi chamado de Plano Nacional de Mineração (PNM - 2010-2030) com o objetivo de nortear as políticas de médio e longo prazos para tornar o setor mineral um alicerce para o desenvolvimento do país nos próximos 20 anos. O governo sustenta que o desenvolvimento depende, em boa parte, da exploração mineral. Com o referido 
Plano, o governo quer garantir o acesso aos obstáculos e às limitações impostas pela legislação.

Conforme documento da CNBB (2015, p. 105), a história da mineração, no Brasil é uma história de apropriação de terras, exploração do trabalho e deslocamento de pessoas pertencentes aos setores mais pobres da sociedade. Dessa forma, fica evidente que a preocupação do governo não é o impacto ambiental e social, mas o modo como vai expandir ainda mais a exploração mineral. O governo avalia que é necessário diversificar as exportações, porque, atualmente, as exportações estão concentradas num único minério, o ferro.

Por outro lado, a sociedade aponta um contraponto a essa ideia de desenvolvimento. Para Malerba (2014, p. 14), ao mesmo tempo, o caráter de prioridade concedido às atividades minerais também se sustenta em uma leitura, com tradição no pensamento de parte da esquerda brasileira, que reivindica que os minérios são bens estratégicos para o estabelecimento de um projeto de desenvolvimento soberano.

Dessa forma, Malerba, a partir de um trabalho que resultou no documento diferentes formas de dizer não, afirma que:

Já existem muitas evidências - no Brasil e em vários países da região como Peru e Argentina, para citarmos apenas dois - de que a mineração em larga escala gera contaminação, devastação e pobreza, e que seus impactos impossibilitam o desenvolvimento de outras atividades econômicas, além de comprometer as bases materiais necessárias para as gerações futuras. (MALERBA, 2014, p. 14).

No estado do Piauí, configura-se a mesma proposta do Governo Federal. O Plano se intensifica a partir do projeto Planalto Piauí e, ao analisar o mapeamento realizado, verificamos que as regiões mais atingidas com pesquisas minerarias, com potencial mineral já catalogado, é o município de Curral Novo, no centro do semiárido piauiense, como também diversos municípios do território Serra da Capivara. 
A QUESTÃO AGRÁRIA NO BRASIL: CAMPESINATO, AGRICULTURA FAMILIAR E AGRONEGÓCIO

Isso gera grande contradição no modelo de desenvolvimento denominado pelo capital e pelo Estado, visto que, no primeiro caso, o município está localizado na região com maior escassez de água, e a extração de minério de ferro necessita de muita água. No segundo caso, trata-se de uma região com a maior área de proteção ambiental, em que diversos espaços onde foram realizadas pesquisas encontram-se dentro da área denominada corredor ecológico, sendo que a atividade mineral causa grande destruição ambiental.

O Estado do Piauí tem sido considerado uma nova fronteira para a mineração devido a considerável variedade de minérios nele encontrados, como minério de ferro, diamantes, fósforo, níquel, mármore, calcário e argila. A região de Curral Novo do Piauí, detém uma das maiores reservas de minério de ferro do Nordeste e a maior do estado.

O macroprojeto Planalto Piauí, se encontra com estágio bastante avançado de responsabilidade da Brasil Exploração Mineral S.A. (BEMISA), empresa integrante do Grupo MT4 Participações e Empreendimentos S/A. O empreendimento, com custos de cerca de 3,4 bilhões de reais, prevê a instalação de uma indústria de exploração de mineração de ferro com sede no município de Paulistana e ações e impactos nos vizinhos municípios de Curral Novo do Piauí e Simões.

A área do projeto abrange os limites administrativos dos três municípios e concentra uma reserva de mais de 800 milhões de toneladas de minério de ferro. Nesse espaço encontra um conjunto de comunidades tradicionais camponesas, entre estas, diversas comunidades quilombolas, com destaque nesse estudo as de Caititu e São Martins, as quais, certamente, terão problemas socioculturais e, visto que o projeto prevê a produção anual de 15 milhões de toneladas de Pellet Feed Fine (minério de ferro de granulometria especial), qualidade Premium. Para tanto, o projeto utilizará a água da barragem Poço do marruá.

Esse caso se constitui em grande contradição, pois, ao mesmo tempo em que se constata que o Semiárido seco, vive buscando várias alternativas, o governo diz que a barragem poço do Marruá justifica o abastecimento de água 
dos municípios da região. Nesse sentido, a região se encontra ameaçada, pois a água, em uma eventual concretização do projeto, passará a ser utilizada em benefício dele, e, consequentemente, as famílias não terão mais acesso a ela.

Este Projeto se vincula à instalação da Ferrovia Transnordestina, que seu trecho passa pelos municípios de curral Novo e Paulistana. O empreendimento da BEMISA, localizado a seis quilômetros da Ferrovia, fará uso da estrada de ferro para escoar sua produção para os portos de Suape, em Recife e de Pecém, em Fortaleza, que têm capacidade de receber navios de grande porte. Já foram assinados termos de entendimento entre a BEMISA e a Transnordestina, além de já estar cadastrada a BEMISA como usuária-dependente da ferrovia junto à Agência Nacional de Transportes Terrestres (ANTT).

De acordo com documentos analisados, os trabalhos exploratórios de pesquisa vêm sendo realizados desde 2008, e seu relatório final foi aprovado no início de 2012. Para proceder à instalação do empreendimento, muitas famílias terão de ser removidas de suas casas; para tanto, está prevista a indenização, bem como a realocação das pessoas. Neste ponto começam os conflitos com as famílias, que temem a subavaliação de suas casas pelo governo e pela mineradora. A maior concentração de comunidades rurais atingidas se dá em Curral Novo do Piauí.

Desde 2007, a empresa mineradora BEMISA chegou à região de Curral Novo com o propósito de implantar o "Projeto Planalto Piauí", para exploração de minério de ferro, impondo aos moradores uma única alternativa: vender ou desocupar as terras para a referida mineradora executar a extração de ferro. As famílias que moram na área de mineração reclamam que estão sendo pressionadas por pessoas que se apresentam como representantes da BEMISA, insistindo para que vendam suas terras.

Fica evidente, a partir da análise da realidade do Semiárido, a existência de uma disputa territorial nesse espaço, surgindo os vários conflitos entre empresas e comunidades camponesas. Diante dessa realidade, surge a resistência das 
comunidades tradicionais como reação ao avanço do capital, tendo por base a luta pelos direitos territoriais e a resistência como elemento central da luta pela terra e na terra.

Assim, as famílias atingidas encontram-se sob ameaça de perda de suas terras, o bem que garante sua sobrevivência. Nesse contexto, vêm recebendo apoio da CPT - (Comissão Pastoral da Terra) e da Diocese de Picos. A igreja, a partir da publicação "Igreja e Mineração", faz algumas reflexões sobre a questão da implantação de projetos de mineração, abordando sobretudo a questão social das famílias impactadas, relacionando com aspectos econômicos.

No caso da mineração vê-se um histórico de violações no tocante a saúde dos trabalhadores e membros das comunidades atingidas, as relações de trabalho e a exploração das riquezas dos povos tradicionais e comunidades indígenas. Não é aceitável que o ser humano fique em segundo plano em nome do lucro. O serviço a vida, princípio estruturante da missão evangelizadora, começa pelo respeito a dignidade da pessoa humana, exigindo que ela seja tratada como fim e não como meio. (CNBB, 2015, p. 130)

Maior que o desenvolvimento econômico está a vida humana. Para a CNBB (2015), a defesa da dignidade humana compreende também a defesa da casa onde vive o ser humano, uma tarefa para a qual a teologia está convidada a participar.

As comunidades atingidas, em especial as comunidades quilombolas, resistem e enfrentam o projeto, impedindo até a realização de pesquisa em seus territórios, tendo por base os conhecimentos tradicionais, a cultura e, sobretudo a defesa da vida e de seus territórios.

A racionalidade econômica dominante desconsidera todos os processos que acontecem no meio ambiente, vendo-o apenas como meio de exploração. Isso é fruto de uma alienação ambiental causada pelo sistema econômico hegemônico vertical que se orienta apenas pelo lucro esquecendo-se do fator humanosocial. Essa postura capitalista ignora todos os valores e saberes entre o ser humano e meio ambiente, que não podem ser vistos isoladamente, uma vez 
que o homem é um animal que integra o meio ambiente e dessa relação surgem saberes, os quais Leff (2001) chama de saber ambiental, um conhecimento harmônico entre o homem e a natureza.

Essa é uma faceta do sistema: criar uma ideologia desenvolvimentista como justificativa para implantação de grandes empreendimentos e violação dos direitos humanos. Como diz ALMEIDA (2008), invocam o desenvolvimento como justificativa para menosprezar os atingidos pela implantação dos grandes projetos.

Nesse sentido, apontamos que, na implementação dos grandes empreendimentos, o capital não consegue enxergar a complexidade das comunidades tradicionais, sua cultura, sua história e a diversificada relação que mantém com a natureza. Na verdade, entendemos que o papel dessas populações é fundamental para a preservação da biodiversidade e conservação ambiental, pois a cultura delas provém dessa relação amistosa.

Para Sousa (2015, p. 55), o reconhecimento de conhecimentos tradicionais implica nova estratégia de luta e defesa das condições ambientais e sociais por parte das comunidades.

Para melhor compreensão dos estudos sobre comunidades tradicionais, mesmo considerando de fundamental importância o pensamento construído por Diegues (2004), buscamos unir um conjunto de elementos que reforçam e identificam as comunidades tradicionais.

A partir da vivência junto às comunidades tradicionais, especialmente as comunidades quilombola ${ }^{1}$, passamos a refletir sobre a dimensão adquirida pelos impactos socioterritoriais nesses agrupamentos humanos. O conhecimento e a identidade das comunidades tradicionais são necessariamente vinculados ao meio circundante, desse modo, quando se atinge o meio ambiente de algum modo se afetam na mesma proporção as populações, uma vez que o ambiente é base material para a cultura, identidade e conhecimentos das comunidades, ou seja, as comunidades tradicionais se identificam a partir desses elementos.

$1 \quad$ Constituídos pelos descendentes de pessoas escravizadas negras, formadas por grupos sociais que ocupam um território comum e compartilham características culturais 
O sistema econômico e o modo de vida que ele nos apresenta faz com que tenhamos uma visão de menosprezo pela natureza, considerando-a inferior ou em situação de "atraso" ou "decadência" todos aqueles povos que não obedecem a homogeneização. $E$ isso é usado como justificativa para a exploração e para evitar algum questionamento ao desenvolvimento e, consequentemente, "permitir" as violações dos direitos humanos.

A consciência ambiental que propomos aqui é uma visão socioambiental, que vislumbra a interação entre populações tradicionais e natureza, uma forma positiva de conservação, rica em memórias, identidades, diversidade que não podem ser ignoradas dessa forma autoritária como está sendo feita, deixando um prejuízo enorme e irreparável ao Patrimônio Imaterial, cujas consequências atingirão as atuais e futuras gerações.

Dessa forma as comunidades rurais da região dos municípios de Curral Novo do Piauí e Paulistana seguem se organizando para estabelecerem suas estratégias de enfrentamento ao avanço das mineradoras sobre suas terras. Esse nível de organização e enfrentamento está vinculado diretamente aos seus conhecimentos tradicionais e ocorre por diversos grupos, com destaque as ações concretas de enfrentamento das comunidades quilombolas São Martins e Caititu.

\section{RESULTADOS E DISCUSSÃO}

É perceptível que um dos principais motivos do distanciamento da população de questões complexas como a dos grandes empreendimentos é que possui teor técnico, ou seja, conteúdo não acessível à população. Além do não sentimento de pertencimento a causas que excedem o convívio direto da população, ignorase tudo aquilo que não é palpável ou que não é sentido de imediato.

É intrigante que exista uma associação tão estreita entre fatores tão importantes tal como política, economia e publicidade, podendo parecer impossível qualquer tipo de resistência contra tal organização. Seria infantilidade tratar a referida estrutura como algo simples de combater, mas seria tão ingênuo quanto afirmar a impossibilidade de se fazer. 
A realidade descrita acima é visível nas diversas comunidades quando da instalação de grandes projetos do capital, realidade percebida em parte das comunidades atingidas pelo projeto mineral em processo bastante avançado na região que compreende os municípios de Paulistana, Curral Novo e Simões.

Com isso as comunidades quilombolas Caititu e São Martins enfrentaram e resistiram à realização de pesquisa dentro de seus territórios por meio de mobilização social e pressão aos que se apresentavam como representes da empresa mineral BEMISA S/A, responsável pelo processo na região.

Descrever a história de uma comunidade é trazer presente sua memória, ocupação humana, avanços, desafios, limites e possibilidades. Caititu e São Martins são comunidades Quilombolas que, ao longo de sua história, convive com sérios problemas. Seu nível de organização e o seu reconhecimento como comunidade Quilombola permitiu o acesso a diversas políticas públicas, porém em meio a essas conquistas nos últimos anos as comunidades vivem em conflito devido a ameaça a chegada de projeto de extração de minérios na região.

Caititu tem esse nome devido a um animal da região, que anos atrás existiam muitos, porém, atualmente, está quase extinto. É uma comunidade Quilombola do município de Curral Novo Piauí. São Martins tem esse nome associado à religiosidade ao Santo padroeiro da comunidade e fica no município de Paulistana, situada na região sudeste do estado do Piauí, na região do semiárido no território Vale do Itaim.

Ao longo de sua história, as populações dessas comunidades se identificaram como quilombolas por reconhecer suas origens a partir da história repassada pelos seus ancestrais e, somente no ano de 2010 foi certificada pela Fundação Palmares como comunidade quilombola.

Atualmente são comunidades quilombolas certificadas pela Fundação Palmares e em processo de titulação pelo INCRA. A partir de suas lutas e mobilizações, elas dispõem de políticas públicas que atende parte das necessidades básicas. 
As famílias preservam os conhecimentos tradicionais a parir do cuidado com a natureza como bem sagrado, plantação e criação de animais apropriados para a região do semiárido e cuidado a preservação de seus conhecimentos a partir da medicina alternativa por meio das plantas medicinais, bem como de sua cultura, crenças e devoções.

As comunidades seguem sua luta e organização pela conquista de diversos direitos, entre os quais a regularização fundiária, como garantia dos direitos a suas terras e territórios e por políticas públicas, principalmente, na disputa com os projetos do capital. Esse direito à regularização das terras e territórios é garantido pela Constituição Federal de 1988, no ADCT 68, reconhece a propriedade definitiva das terras historicamente ocupadas por comunidades remanescentes de quilombos, como consta no Artigo 68. Zhouri (2018) destaca que a flexibilidade das normas e o retrocesso institucional colocam em questão a própria noção de democracia e configuram um dos "efeitos derrame da mineração".

Mesmo com todo o aparato jurídico, as comunidades necessitam permanecer na luta pela garantia de seus direitos, visto que a cada dia existe a flexibilidade das leis como forma de facilitar a implantação dos grandes projetos minerários.

Nos últimos, anos as lutas se intensificaram contra a implantação de grandes projetos do capital na região, merecendo destaque o projeto de pesquisa para extração de minérios (ferro).

Nessa linha de pensamento, Malerba (2014), contribui com esse entendimento ao afirmar

Portanto, diante das ameaças de retrocesso a direitos adquiridos e de expansão acelerada da mineração sobre novas fronteiras, está posto aos movimentos e organizações críticas o desafio de acumular subsídios que contribuam para disputar o sentido da prioridade dada pelos governos as atividades minerais em relação a outros usos econômicos e culturais dos territórios. (MALERBA, 2014, p. 17).

As comunidades tradicionais, que possuem uma relação histórico-cultural com o território do semiárido piauiense, torna-se, na conjuntura atual, alvo do avanço desse grande empreendimento inserido no modo de produção capitalista, 
o qual avança, desrespeitando inúmeros direitos abarcadas pelo poder constituinte de 1988, inclusive de as famílias optarem pelo tipo de desenvolvimento que preferem. Partindo da mesma compreensão, outro aspecto a ser destacado das comunidades está relacionado ao patrimônio cultural, a que se referem os artigos 215 e 216, reconhecendo a importância de preservar o patrimônio cultural, tratando até mesmo da democratização do acesso aos bens culturais.

Dispondo dos conhecimentos tradicionais já citados neste trabalho bem como dos conhecimentos acerca dos dispositivos legais, vão intensificando as lutas e resistências das famílias camponesas nos seus territórios contra as pesquisas e aquisição de terras para exploração mineral.

No tocante às ameaças dos grandes projetos do capital, podem-se destacar três pontos como forma de enfrentamento a eles pelas comunidades, com resultados positivos. O primeiro é a vigilância por parte das próprias famílias, não permitindo a entrada da empresa para a realização das pesquisas dentro da comunidade; o segundo, é o encaminhamento de processo via o INCRA, para impedir a pesquisa dentro da comunidade por se tratar de comunidades tradicionais, com resultado positivo ao pedido; e o terceiro ponto é a luta junto com as demais comunidades atingidas no seu entorno, já que integram também a categoria comunidades tradicionais. Além dos direitos de que elas dispõem, reconhecem que a extração de minérios prejudica comunidades vizinhas, dessa forma, as comunidades quilombolas onde não será extraído minérios também seriam atingidas.

Os resultados positivos são fruto de uma luta e enfrentamento ao longo de uma história, e não apenas de um momento pontual. Quanto a não permissão da realização das pesquisas na comunidade, inicia-se com a construção de mobilização e formas de enfretamento por se tratar de grande empresa com fortes influência nos diversos espaços, porém as duas comunidades mantêm uma regra que consiste em não permitir a intervenção de pessoa estranha antes de um amplo diálogo com a empresa. 
A QUESTÃO AGRÁRIA NO BRASIL: CAMPESINATO, AGRICULTURA FAMILIAR E AGRONEGÓCIO

Por fim, percebe-se a necessidade da continuidade da luta e do envolvimento das instituições parceiras para garantia dos direitos já conquistados, tais como os documentos que garantem a não realização da pesquisa nas comunidades quilombolas, sobretudo a suspensão definitiva das pesquisas nas demais comunidades que se encontram suspensas temporariamente. Entende-se que a concretização do projeto dentro das demais comunidades atinge diretamente as comunidades quilombolas.

\section{CONCLUSÃO}

O Brasil é um país com grande potencial de recursos naturais, em especial mineral, por sua grande diversidade geológica e extensão territorial, fato que leva ao grande interesse dos grupos empresariais para a exploração desses recursos, visando à concentração do capital em nome do desenvolvimento. Mas é importante ressaltar que a atividade da forma que está sendo desenvolvida pode gerar sérios impactos socioambientais e culturais.

O Estado do Piauí configura a mesma realidade das demais regiões do Brasil, por dispor de grande potencial mineral, destacando-se como mais agravante a relação que vem sendo construída entre o capital estatal e o capital empresarial para a implantação dos projetos.

Os grandes projetos para o setor, de imediato, preveem a geração de miIhares de postos de emprego, crescimento econômico e social para a região, no que diz respeito à infraestrutura, escolas, empresas, hotelaria, aeroporto, avanço dos meios de comunicação e de tecnologia empregada em todo o comércio local e industrial. Mas, em contrapartida, gera um acréscimo populacional desenfreado e uma diversidade cultural em virtude da grande quantidade de pessoas vindas de outras regiões; a expropriação da população local devido a exigência cada vez mais de uma mão de obra qualificada de que parte dessa população não dispõe.

Aqui cabe questionar a legitimidade desses projetos e a quem serve esse desenvolvimento, visto que não inclui nem beneficia a população, degrada os re- 
cursos naturais, prejudica a biodiversidade e o pior de tudo: muitas vezes, sequer fornecem informações ou realizam consultas com os indivíduos afetados.

Diante dessa realidade, as populações resistem ao projeto de desenvolvimento imposto pelo capital e utilizam seus conhecimentos e organizações para a garantia de seus direitos socioculturais. Os níveis de resistências bem como a conquista de direito tornam-se visíveis no conjunto de comunidades tradicionais, com maior visibilidade nas comunidades quilombolas.

A atuação das comunidades quilombolas Caititu e São Martins são exemplos de enfrentamentos para as demais comunidades atingidas, ao iniciar pelo enfrentamento direto à empresa no momento da realização da pesquisa, enfrentando obstáculos nos encaminhamentos de documentos como garantia efetiva dos direitos reivindicados.

Conclui-se que a promessa do desenvolvimento não envolve as comunidades rurais piauienses; o argumento da supremacia do interesse público é apenas uma desculpa para mascarar o interesse privado, que desconsidera o conhecimento tradicional presentes nas comunidades atingidas pelos já referidos projetos. A partir disso, infere-se, principalmente, que esses empreendimentos são ilícitos e ilegítimos, uma vez que não respeita a perspectiva dos atingidos, infringe a lei e prejudica as pessoas e o meio ambiente. Entende-se que é por meio da organização das comunidades, da luta e resistência que é possível garantir os direitos.

\section{REFERENCIAS}

ALMEIDA, Alfredo Wagner Berno de: Antropologia dos arehios da Amazônia..Rio de janeiro 2008. BRASIL. Constituição da República Federativa do Brasil. Brasília, DF, 1988.

CONFERÊNCIA NACIONAL DOS BISPOS. (CNBB). Conferência do Brasil. A Igreja e a questão agrária brasileira no século XXI. Edições CNBB, 2014. 
. A Igreja e Mineração - em defesa da vida e dos territórios. Edições CNBB, 2015.

DIEGUES, Antonio Carlos: O mito moderno da natureza intocada. HUCITEC, São Paulo, 2004.

DUPAS, Gilberto: O mito do progresso. Ed. UNESPI. São Paulo, 2006.

LEFF, Enrique: Epistimologia Ambiental. Cortez 2001.

LEFF, Enrique. Saber ambietal: sustentabilidade racionalidade, complexidade poder. 2.ed. Rio de Janeiro: Vozes, 2002..

MALERBA, Julianna (org.) Diferentes formas de dizer não: experiências de resistência, restrição e proibição ao extrativismo mineral. Rio de Janeiro: Fase, 2014.

Mineração: violências e resistências [livro eletrônico]: um campo aberto à produção de conhecimento no Brasil. / Andréa Zhouri (Org.); R. Oliveira et all._ 1.ed.- Marabá, PA : Editorial iGuana; ABA, 2018. 711 kb ; e-PUB .

SOUSA, Maria Sueli Rodrigues de. Desenvolvimento, conhecimentos tradicionais e direitos humanos: populações tradicionais e quilombolas do Estado do Piauí e a defesa do meio socioambiental. Teresina: EDUFPI, 2015. 
dol $10.48209 / 978-Q R-89949-02-6$

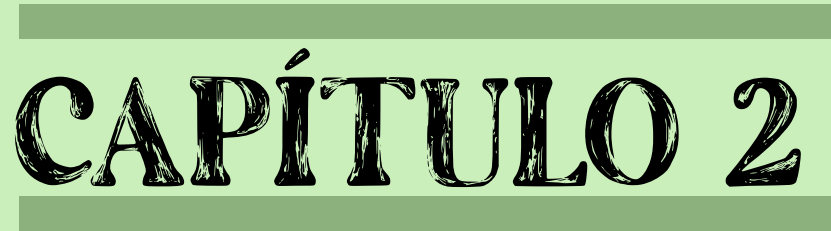

A FALÁCIA DO DISCURSO DE MODERNIZAÇÃO NO CAMPO E A APROPRIAÇÃO DA TERRA E DA ÁGUA PELO CAPITAL NO PLATÔ DE NEÓPOLIS - SE

Mara Íris Barreto Lima Josefa de Lisboa Santos Bruno Andrade Ribeiro 


\section{INTRODUÇÃO}

O objetivo deste artigo foi analisar as facetas do capital no campo, através de uma discussão acerca das contradições do Projeto Platô de Neópolis no Nordeste Sergipano, que mantém indicadores de pobreza mais longevos do estado, tal como desvelar a falácia de um projeto modernizador, que garantiria emprego e alimentos para a população ribeirinha. Desse modo, a fim de apreender o avanço do agrohidronegócio, as resistências camponesas via luta por terra eágua se constituíram fundamentais para compreender as formas de produção e reprodução do espaço agrário sergipano.

Neste ínterim, os trabalhos de campo, somados à leitura de livros e pesquisas, além dos registros fotográficos e a análise de relatos forneceram embasamento teórico-metodológico para que se desenvolvessem conhecimentos sobre a problemática permitindo revelar os falsos discursos de modernização e a territorialização do capital no campo. Diante disso, foi possívelanalisar que mesmo que as relações capitalistas avancem sobre o espaço agrário, através do agrohidronegócio com o aval do Estado, há permanência dos camponeses, pescadores artesanais e das comunidades quilombolas, com suas lutas e resistências históricas, as quais sevalorizam pela produção camponesa familiar - mais saudável e sustentável à sua plena reprodução social.

Às margens das águas do baixo curso do Rio São Francisco, no estado de Sergipe, engendrada por relações capitalistas de produção no campo, encontra-se uma área produzida por um processo de distribuição de terras reversa, conhecido como Projeto Platô de Neópolis, envolvendo os municípios de Neópolis, Japoatã, Pacatuba e Santana do São Francisco.

O referido projeto foi implantado no ano de 1992, por incentivos do Governo do Estado, responsável pela elaboração, planejamento e construção de infraestrutura e condições deoperacionalização dos processos de produção e de comercialização em diferentes escalas, além da fiscalização realizada pela em- 
presa estatal Companhia de Desenvolvimento de Recursos Hídricos e Irrigação de Sergipe - COHIDRO.

A área do projeto ultrapassa 10.000 hectares, com mais de 7.000 hectares irrigados, comaproximadamente $50 \mathrm{~km}$ de canais que bombeiam as águas do Rio São Francisco em quatro estações para o abastecimento do Platô. As terras foram divididas em 40 lotes para empresáriosintegrantes da Associação dos Concessionários do Distrito de Irrigação do Platô de Neópolis -ASCONDIR, a qual organiza a exportação da produção agrícola, com destaque para a produção de frutas comerciais, entre as quais se destacam a produção de coco verde, manga, maracujá, limão e dentre outros produtos além da produção de cana-de-açúcar e de grama (ASCONDIR, 2019).

A presença das empresas parceiras expõe a territorialização do capital no campo. Não obstante, essas terras encontraram-se disputadas e permeadas por conflitualidades, que envolvem de um lado, aqueles que lutam pelo acesso à terra e a legitimação de sua função social, e do outro lado, os que detém poder econômico e influenciam o poder políticocolocando-o a seu serviço. O reflexo disso é a presença de empresários do setor urbano assumindo o controle das melhores terras e se tornando agentes do agrohidronegócio com o apoio financeiro do Estado, validando a manutenção de privilégios enraizados.

Outrossim, acerca do agronegócio no Vale do Rio São Francisco, bem como os seus desdobramentos, Sousa (2013) pontua os discursos sobre a modernização do espaço agrário queestão engendrados a partir de interesses oriundos de uma elite política e econômica, "[...] a imposição velada reproduziu antigas relações de trabalho baseadas no domínio do trabalhador, tendo como resultado a perda da autonomia em produzir para suprir suas necessidades." (SOUSA, 2013, p. 72).

As estratégias encontradas pelo campesinato da região para se reproduzir e se ainda realizam lutas para conquistar esse território se constituíram centrais nessa pesquisa. Aprodução realizada nos lotes do Platô, ocupados pelas empre- 
sas, ao mesmo tempo expressa a simbiose entre o "moderno" ou "novo" e o "arcaico" ou "tradicional" no Baixo Vale do Rio São Francisco e está voltada para o comércio no estado e no exterior. Observa-se umaapropriação de terra e água por empresários capitalistas, com o aval do Estado, em um territóriocuja presença de camponeses pobres é visível. Dessa forma, é preciso questionar: como a ideologia do capital mascara suas ações para dissimular a realidade?

Assim, a partir da análise dos desdobramentos da modernização no campo e seu discursofalacioso de desenvolvimento na realidade observada no Platô de Neópolis, Sergipe, foi possível desvelar os impasses que ocultam tal problemática. Observa-se que o campesinato e as comunidades ribeirinhas do Baixo São Franciscoㄹ lutam para sobreviver do campo e no campo. Confrontam-se com os interesses do capital, ao reivindicar o acesso à terra e à água na região, com vistas a melhorar as condições de vida de todos os trabalhadores ribeirinhos, de modo a impulsionar a produção camponesa ${ }^{3}$ mais saudável e produtiva.

\section{ANÁLISE DAS CONDIÇÕES EDAFOCLIMÁTICAS DO TERRITÓRIO DO PLATÓ DE NEÓPOLIS - SE}

O referido projeto, conhecido como Platô de Neópolis, recebe este nome em virtude dascondições geomorfológicas da região, a qual se encontra dentro dos Tabuleiros Costeiros, à margem direita do Baixo Vale do Rio São Francisco - próximo à foz - no Nordeste do estado de Sergipe (figura 1).

2 Integra os municípios de Amparo de São Francisco, Brejo Grande, Canhoba, Cedro de São João, llha das Flores, Japoatã, Malhada dos Bois, Muribeca, Neópolis, Pacatuba, Propriá, Santana do São Francisco, São Francisco e Telha.

3 A partir da observação em campo, percebeu-se que a produção familiar camponesa proporciona a função social da terra, no entanto, concordamos com Ariovaldo U. de Oliveira (2016, p. 123-124) quando ressalta que, "a lógica neoliberal atua no sentido de tentar converter todo alimento produzido em mercadoria, não para ser consumido pelos que produziram, mas para ser adquirido por quem tenha dinheiro, onde quer que esteja no mundo". 
Figura 1 - Localização do Platô de Neópolis, Baixo São Francisco, Sergipe, 2019

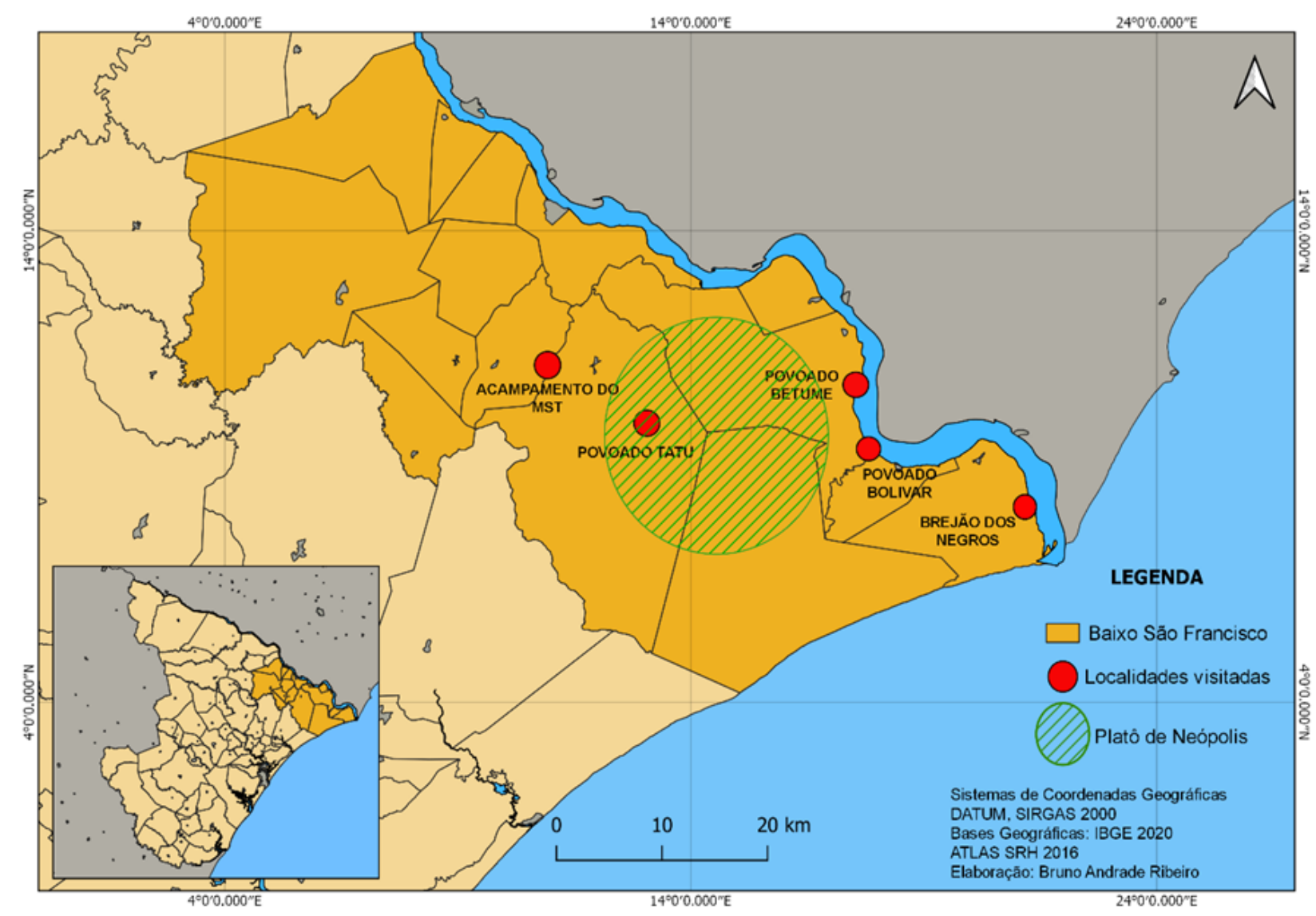

Fonte: SRH (2016).

Elaboração: RIBEIRO, Bruno Andrade (2019).

De acordo com informações da ASCONDIR (2019), o Platô tem uma área total de 10.432 ha, sendo aproximadamente 7.230 ha irrigados, considerando-se também a área destinada para reserva legal. Nestas condições, mesmo com o regime hidrológico pelas águas do Rio São Francisco, os solos da localidade apresentam baixa fertilidade e alta infiltração, cabendo assimo uso de técnicas avançadas e pesquisas para promover a produtividade, a partir do emprego dealtas tecnologias, instrumentos de correção e manejo do solo, uso de fertilizantes, herbicidas efungicidas contra as pragas e doenças que acometem os diferentes cultivos, como o exemplo da produção de coco verde nos lotes (figura 2). 
Figura 2 - Produção de coco verde em lotes do Projeto Platô de Neópolis: territorialização do capital no campo

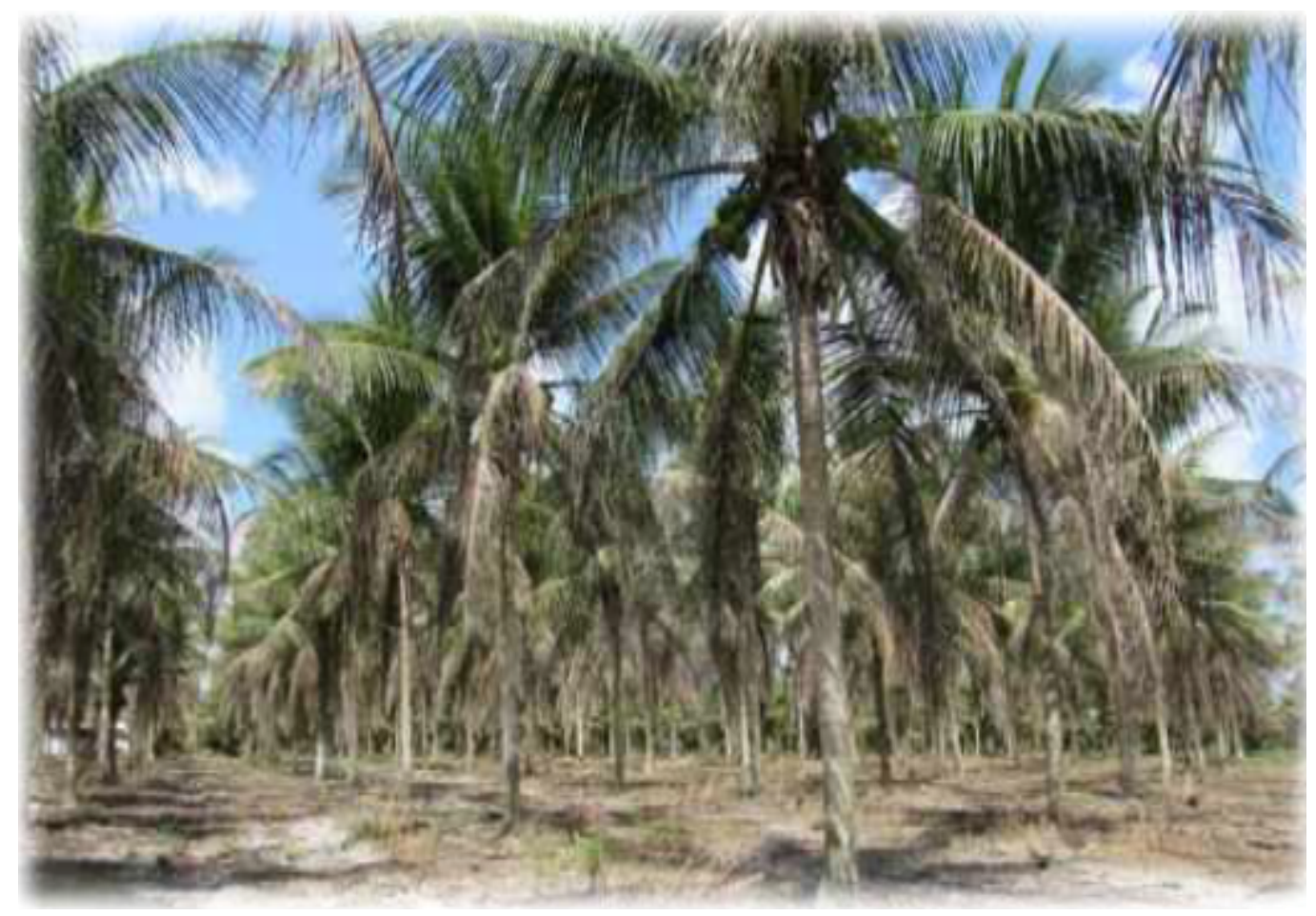

Fonte: LIMA, Mara Íris Barreto (2019).

De acordo com informações da Empresa Brasileira de Pesquisa Agropecuária (EmbrapaTabuleiros Costeiros), a pedologia do Platô de Neópolis, por apresentar uma baixa retenção deágua, caracteriza-se pela presença de solos com texturas arenosas e argissolos. O clima semi-úmido do litoral se apresenta muito importante no período de safra das diferentes culturas, comchuvas concentradas entre maio a agosto e temperatura média anual de $25,6^{\circ} \mathrm{C}$.

As informações das condições edafoclimáticas são importantes para mostrar os interesses do capital naquela área, pois o capital se apropria dessas riquezas naturais conformando agrohidroterritórios, terras ricas em solo e drenagem para assegurar-Ihe ganhos de produtividade. De acordo com Thomaz Jr (2017), o agrohidronegócio é a relação entre a busca do capital por terras férteis, com grande disponibilidade e capacidade hídrica, em que consiste numa lógica de acumulação do capital expropriando comunidades tradicionais, camponeses e demais sujeitos. 
O relevo plano e ondulado, circundado por encostas e solos de baixa capacidade de retenção de água e nutrientes, que constituem os tabuleiros costeiros de Sergipe foram beneficiados com a irrigação planejada (VASCONCELOS, 2015).

O intuito da diversificação da produção de frutas comerciais, tal como a monocultura da cana-de-açúcar e a produção de grama fomentaram diferenciados processos e estudos acercadas condições naturais no Baixo São Francisco, sobretudo as pesquisas sobre a capacidade hídrica da região, assim como as técnicas de melhoramento dos solos. Assim, utiliza-se de métodos e procedimentos que "racionalizam" os recursos hídricos no platô, tentando ainda minimizar os gastos por parte das empresas e do Estado.

\section{O AGROHIDRONEGÓCIO COMO CONDIÇÃO DA OFENSIVA NEOLIBERAL NO CAMPO}

A construção ideológica e materializada pela ofensiva neoliberal se exprime no campo,como motor imprescindível da acumulação do capital que tem o lucro como principal objetivo.A década de 1960 marca as dinâmicas das relações sociais no campo e o amadurecimento do Complexo Agroindustrial (CAI), em um contexto que concentra as tensões no campo gestacionadas pelos movimentos sociais de luta pela terra e pela eufórica elite urbana, preocupada em abrir o mercado gradativamente (CAMPOS, 2009).

Para Campos (2009, p. 24-25),

É importante destacar que no Brasil o conceito de CAl serviu de suporte teórico paradensas críticas ao processo de modernização da agricultura. Esses estudos não se restringiram a compreender o funcionamento das cadeias produtivas, englobaram os impactos socioeconômicos das mudanças (como por exemplo, na divisão do trabalho)bem como das permanências (concentração fundiária, por exemplo) (CAMPOS, 2009, p. 24-25).

O agronegócio é a expressão macabra de uma elite que controla não apenas os setores agropecuário e agroindustrial, mas também a comercialização 
A QUESTÃO AGRÁRIA NO BRASIL: CAMPESINATO, AGRICULTURA FAMILIAR E AGRONEGÓCIO

e o mercado, além de ser protegido pela grande mídia e exercer poder político. De acordo com Vasconcelos (2015), este modelo está "associado a novos empreendimentos técnico-científicos, de ideias criativas e inovadoras para um Novo Mundo Rural, o agronegócio se consolida como anunciador de transformações." (VASCONCELOS, 2015, p. 91).

Não obstante, Oliveira (2016) aponta em contraposição à mundialização do capital e que consequentemente, a produção familiar camponesa se transforma a partir dos interesses docapital, substituindo a ideia de soberania alimentar pela de segurança alimentar. Ou seja, com o processo de modernização da agricultura, segundo Oliveira (2016, p. 123), "a fome nãofoi erradicada do mundo, pois, em 2014, havia 805 milhões de pessoas passando fome no planeta", logo se compreende que o discurso capitalista de acabar com a fome por meio da Revolução Verde é uma verdadeira falácia.

Campos (2009) chama a atenção na modernização do espaço agrário engendrada a partir dos interesses das classes político-econômicas, controlada por empresas e pessoas físicas, as quais buscam o domínio dos territórios. Essa ofensiva se projeta dentro das políticaspúblicas do Estado, responsáveis por favorecer a iniciativa privada, como é expressivo no recorte geográfico do Projeto Platô de Neópolis, apreendendo-se que, desde a sua idealização até sua implementação, o capital se legitima contra a reprodução social das comunidades ribeirinhas, desassistidas e que ainda hoje lutam por seus direitos sociais.

Por sua vez, o reflexo disso é a presença de empresários urbanos assumindo o controle das melhores terras e se tornando agentes do agrohidronegócio no Baixo São Francisco (figura 3). Esse modelo de apropriação do agrohidronegócio - fruto de articulações de capitais que abarcam diversos setores da sociedade escamoteia as suas estratégias, com o apoio explícito do Estado, o qual tinha o discurso de acabar com o desemprego e com a pobreza.

Todavia, observa-se o seu contrário, o agrohidronegócio na região implica gradativamente os desmontes acerca das relações de trabalho, acentuando o 
desemprego como problema estrutural, bem como chama a atenção para a pobreza das comunidades que são alvos desse caráter predador da modernização do/no campo.

Figura 3 - Presença de empresa agrícola no Platô: apropriação de terra e água pelo capital no campo

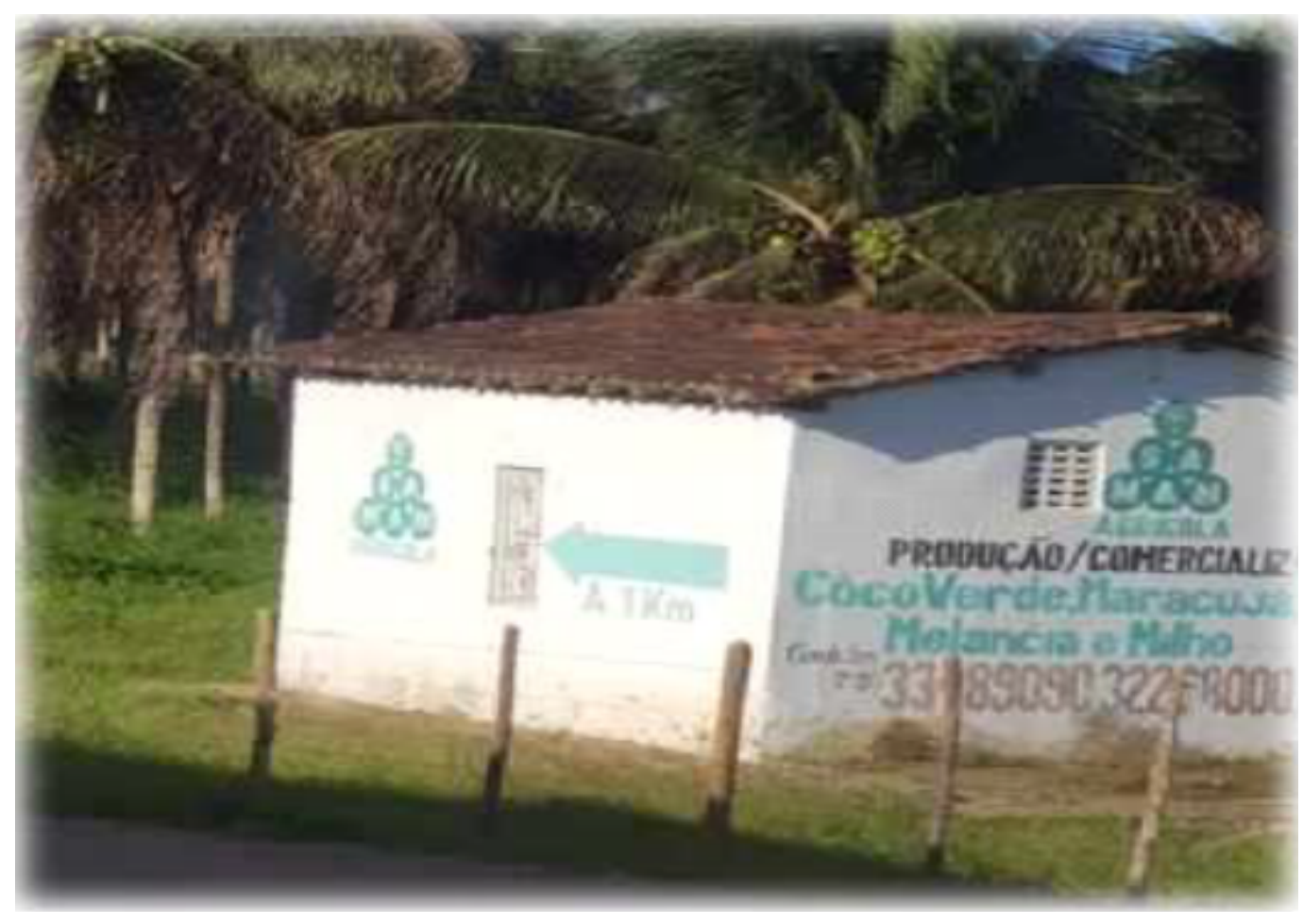

Fonte: SILVA, Daniel Almeida da (2018).

\section{RESULTADOS E DISCUSSÃO}

Outrossim, "o amplo apoio institucional que o agrohidronegócio recebe das mais distintas esferas governamentais e a difusão no imaginário social da representação doagrohidronegócio como corolário de desenvolvimento rural e de riqueza no país" (CAMPOS, 2009, p. 28), esconde os interesses dos representantes do neoliberalismo, enquanto umaorganização crucial, repleta de reformas que não beneficiam o povo, mas sim um pequeno grupoque subordina a maioria e se enriquece paulatinamente.

Por conseguinte, o Projeto Platô de Neópolis - SE, implantado em 1992, durante o governo de João Alves Filho (mandato de 1991 a 1994), desdobra-se 
através de um modeloinstitucional misto, em que o Governo do Estado firma parceria com diversos empresáriosadvindos do setor urbano, como a exemplo, da capital Aracaju - SE, além de outros municípios e fora do estado, segundo informações da ASCONDIR (2019).

Essa realidade mostra uma distribuição das melhores terras com perímetros irrigados, englobando a exportação da produção agrícola, principalmente a produção de frutas, como, por exemplos, coco verde, manga, limão e dentre outras e extensas faixas de terras destinadas à cana-de-açúcar e à produção de grama (figura 4).

É imprescindível explanar que os cultivos existentes antes da instalação do Platô estavam voltados para o consumo das famílias locais, uma agricultura de rica variedade e de subsistência aniquilada por mares de cana, grama e frutas comerciais. Tal situação é consequência do agrohidronegócio, porque mina as águas do Rio São Francisco com a finalidade de lucratividade e por não romper com as marcas das desigualdades alarmantes que assolam essa região. Este projeto de destruição consegue então envenenar a terra e a água que são bens preciosos para a vida de um povo.

Figura 4 - Apropriação da água: irrigação de grama com uso de pivô central no Projeto Platô de Neópolis - SE

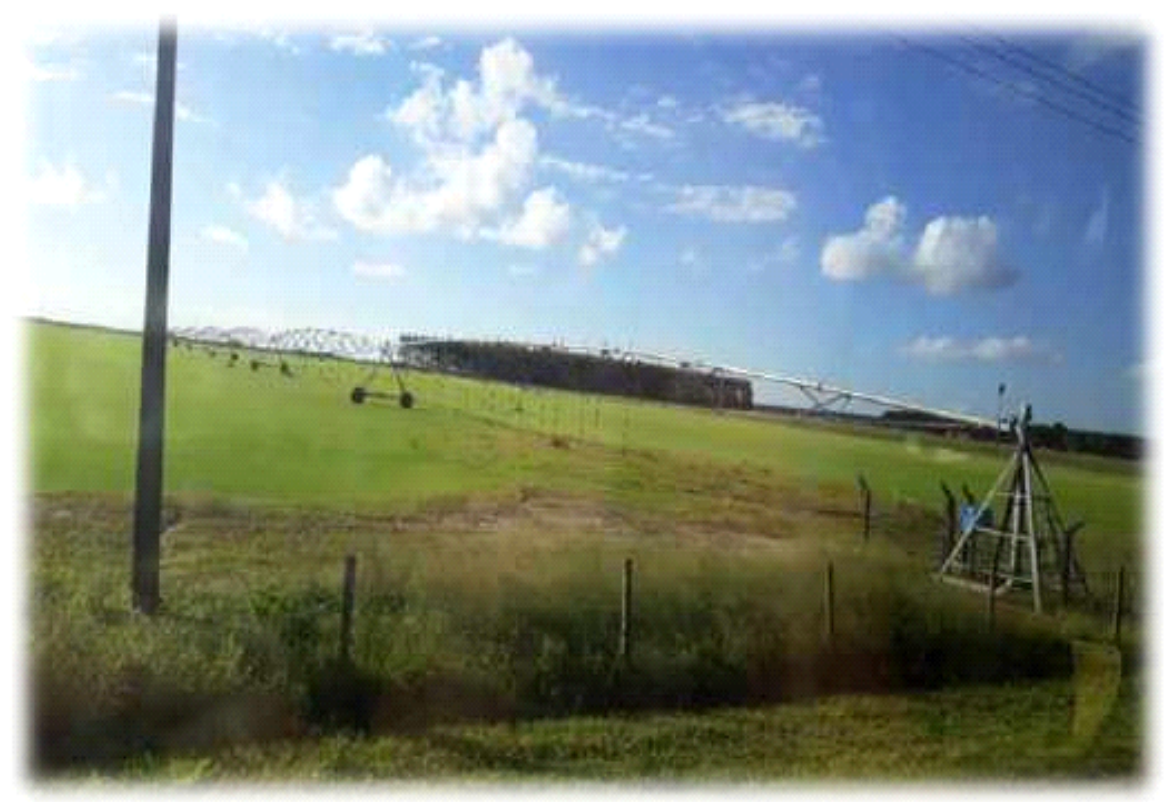

Fonte: LIMA, Mara Íris Barreto (2019). 
Os municípios que englobam o Platô de Neópolis estão situados na região de maior incidência de pobreza em Sergipe. Os baixos IDHs denunciam a atuação do Estado em uma região já assistida pela Companhia de Desenvolvimento do Vale São Francisco e do Parnaíba - Codevasf, com diferentes políticas públicas, mas que não conseguiram erradicar a pobreza.

Dentro dessa interpretação, Sousa (2013), expõe que a Codevasf foi

[...] criada em 1947, sendo reformulada no ano de 1967 para dar maior dinamização ao órgão e uma uniformização entre as agências governamentais de desenvolvimento. No ano de 1975, a mesma é reformulada dentro de uma filosofia empresarial, para atuar na politica de água e de irrigação, ou seja, criar projetos, implantá-los e fazer com que eles funcionassem com ampla produção para o mercado. Assim, o Perímetrolrrigado passa a ser uma realidade (SOUSA, 2013, p. 47).

A sede da Codevasf situada no povoado Betume em Neópolis - SE, atua de modo a mantera população local nos pequenos lotes de terras, compreendendo os destaques para a produção de arroz e a atividade pesqueira. Segundo relato do engenheiro de pesca da sede, este projeto -o Projeto Betume - é referente às políticas públicas de cunho social oriundas dos impactos da construção de hidrelétricas do Vale São Francisco a partir da década de 1970. Essas medidas mitigadoras implicaram em financiamentos para promover a construção de perímetros irrigadosna década de 1980, mitigando a situação para as comunidades ribeirinhas. Para Sousa (2013), a necessidade disso, acontece na medida em que:

Nesse percurso, de forma imperativa, os países pobres, entre eles o Brasil, deveriam adquirir financiamentos como uma condição necessária ao desenvolvimento rural. Deposse desses financiamentos, o Governo brasileiro passou a planejar e executar um "novo" modelo de agricultura para a Região Nordeste, sobretudo no Sertão Nordestino, tendo como base a irrigação possibilitada pelas águas do rio São Francisco (SOUSA, 2013, p. 47).

Nessa lógica, as particularidades do recorte geográfico explicitam a organização de sindicatos, associações, cooperativas e demais coletivos que lutam e resistem pela terra e pelaágua como condição de reprodução socioespacial. Contra a ofensiva neoliberal pregada pelosagentes do agrohidronegócio, 
tal como contra a posição do Estado, compreende-se a nítidahistória de subordinações e readequações por parte desses sujeitos excluídos, que sentem napele os rebatimentos da apropriação da água pelo capital, bem como de suas terras e produções.

Assim, Vasconcelos (2015) observa que o processo de expropriação da população da região que engloba o platô deixou "[...] de fora a maioria dos trabaIhadores e onde a pobreza continua inabalável sem alterar sua marca histórica da permanência da exploração" (VASCONCELOS, 2015, p. 53).

Outra questão de destaque é referente aos impactos ambientais que acometem a produção agrícola, com o uso desenfreado de venenos com a finalidade de aumentar a produtividade, e em contrapartida, aumentando a dependência dessas substâncias no campo ocasionando impactos na saúde dos trabalhadores ribeirinhos, na terra e na água.

As comunidades ficam submetidas a um espetáculo desumano por parte de uma elite exploradora que impulsiona a espacialização de conflitos no entorno do Platô. São variados impactos socioambientais que afetam os mais desfavorecidos e enriquecem e mantém os privilégios enraizados de grupos que dominam distintos setores da economia, tanto no campo quanto na cidade, e em diferentes escalas.

No bojo dessas relações contraditórias, tem-se dimensão da situação que se encontra a população local: uma extrema subordinação aos ditames dos empresários capitalistas, assim como a situação de dependência dos meios de trabalho que estes indivíduos têm ao seconfrontarem como a única saída em prol da própria sobrevivência. Logo, fica claro conforme depoimento do técnico L. R. de uma das empresas que é beneficiada com lotes do Platô:

Aqui próximo tem um assentamento, que é o Pindoba, tem um outro que é o Betume.Assim, geralmente esses assentamentos é tudo legalizado pelo governo, o governo pega uma terra, não que eles entram e invadem, não ocorre isso, e a própria mão de obra deles é aproveitada aqui, é tanto que temos vários funcionários desses assentamentos aqui (Trabalho de campo, Ago/2019).

4 Pesquisa de campo na disciplina Geografia Agrária realizada no Platô de Neópolis SE. Entrevista com técnico de uma das empresas presente no Platô em Agosto de 2019. 
A população torna-se, como é explícito no relato, força de trabalho que não tem garantiaalguma de seus direitos sociais, mas sim subordinada aos trabalhos temporários/parciais, ou como são conhecidos por "funcionários safra" na região. Não são funcionários fixos que, por sua vez, não possuem carteira de trabalho assinada e melhores garantias de vida. Desse modo, as comunidades locais se tornam submissas a estas amarras, ao mesmo tempo em que se ampliam as suas expressões de resistências, ocupações e lutas.

É seguindo essa linha de pensamento que se tem verificado que as comunidades englobadas no Platô de Neópolis se encontram permeadas por conflitualidades e pelos intensosataques do agrohidronegócio. Desde uma população que teve suas terras desapropriadas pelo projeto e que ainda resiste, como o exemplo da comunidade do povoado Tatu, nos limites do Platô, no município de Japoatã - SE, aos que se encontram acampados e assentados nas proximidades do projeto disputando a posse da terra em lotes ociosos, onde não existe nenhum tipo de produção (figura 5), expressando assim as contradições do capital no campo.

Figura 5 - Acampamento de famílias pelo MST nas proximidades do Projeto Platô de Neópolis: condição de luta e reprodução pela terra

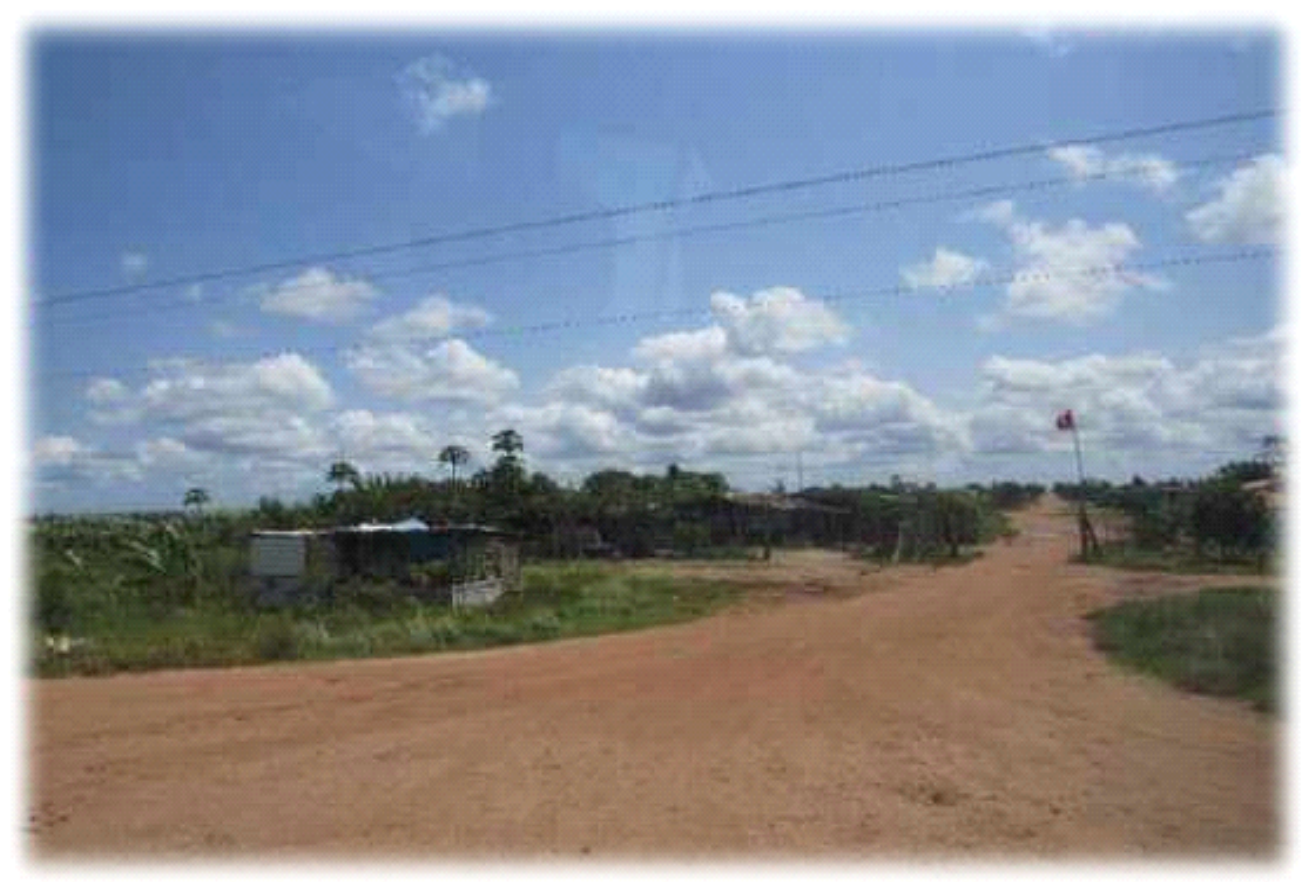

Fonte: LIMA, Mara Íris Barreto (2019). 
As lutas incessantes de movimentos camponeses, entre eles o Movimento dos Trabalhadores Rurais Sem Terra (MST) - integrado à jornada Mundial das lutas da Via Campesina, cobram e protestam por ações do Estado, enquanto o agente que deveria garantir direitos fundamentais, entre eles a alimentação, atua para expandir o agrohidronegócio de empresários do campo, o que se reflete na manutenção de grandes lotes de terra, além de corroborar com o uso intensivo de venenos que poluem os solos e os lençóis freáticos.

Ademais, de acordo com Sousa (2013, p. 72):

É importante mencionar que a materialização dos Perímetros Públicos Irrigados se deu pela expropriação dos que lá exerciam a posse da terra pelo trabalho. Se ali eles quisessem ficar, teriam de concorrer com outros trabalhadores de toda a Região Nordeste e fora dela. Contraditoriamente, o que seria um espaço público se transformou em um espaço privado ocupado pelos "melhores" trabalhadores dotados de disposição para cumprirem as regras criadas e ditadas pelo Estado como condiçãode sua permanência no lote (SOUSA, 2013, p. 72).

Dito isto, acerca dos desdobramentos socioambientais que acometem os ribeirinhos, apreende-se que, em prol do mercado há a captura das formas de subsistência, desde a produção agrícola de autoconsumo, aos recursos pesqueiros das comunidades que retiram destes a sua renda, ao mesmo tempo em que amplia cada vez mais o avanço das empresas em territórios de resistência de tais sujeitos históricos e políticos.

Tais observações são imprescindíveis ainda ao compreender que, tanto as famílias dos assentamentosque estão às margens do Platô quanto às outras comunidades sofrem com os avanços do capital com a modernização no campo. Haja vista, a população ribeirinha do Rio São Francisco atualmente se encontra desamparada pelo governo, tendo em vista também as intensas perseguições e ataques às lideranças dos movimentos organizados.

O discurso de modernização na região envolve também as comunidades quilombolas, como o exemplo das comunidades de Brejão dos Negros e de Resina. Com destaque para Brejãodos Negros, no município de Brejo Grande - SE, 
destacaram-se a apropriação do território quilombola (como direito seguindo a Constituição Federal de 1988), suas fontes de renda, pautada principalmente na pesca de peixes e camarões e também pela agricultura de subsistência, onde há um cercamento por parte dos grupos dominantes. Nessa realidade se vislumbra a agressividade dos representantes do agrohidronegócio que não se cansam de tentar destruir o modo de vida desses sujeitos, como énotório na fala de um integrante, M. A. S., da comunidade supracitada:

A gente podia encostar um barco, podia saltar, chegava no muro a gente fazia um fogoe podia assar um peixe né, hoje em dia nem um barco você pode encostar, porque o cara chega com uma 12 e diz: caia fora porque o dono não quer ver ninguém aqui não,aí você tem que sair, é uma coisa que no tempo de meu pai não existia, mas agora é isso que a gente tá vendo... A comunidade se cria da luta e vive da luta (Trabalho de campo, Ago/2019).

É mediante tal compreensão que se esclarece, objetivamente, a necessidade da luta desses trabalhadores, independentemente de suas singularidades. Neste sentido, mostrou-se que são famílias que lutam pelo direito à terra e pelo direito à água, todavia, são alvos do caráterameaçador de grupos dominantes, os quais pressionam e perseguem constantemente essas comunidades que vivem às margens do Rio São Francisco. Elas se encontram desnorteadas, tentando resistir de diversas formas, recorrendo à justiça e aos demais meios, tendo em vista que pelas contradições do capitalismo, o Estado Brasileiro não soluciona os problemas referentes à concentração de terras, os conflitos socioambientais que envolvem esses sujeitos e a própria mercantilização da Natureza.

A partir de variados relatos, pode-se afirmar segundo uma das representantes da comunidade Brejão dos Negros, M. I. S. S., que:

As comunidades quilombolas elas não era reconhecidas como público da Reforma Agrária, apesar da gente tá no plano, estava no plano, mas a gente não era reconhecido, o Incra não reconhecia as comunidades quilombolas, só reconhecia os assentados e aífoi uma briga né, foi uma luta muito grande, começamos a reunir os dados né, fazer os movimentos e nós tivemos que fazer isso quase que formando um grupo secreto pra discutir secretamente, isso partiu daqui de Sergipe, o menor Estado, fomos os primeiros a fazer isso (Trabalho de campo, Ago/2019). 
A QUESTÃO AGRÁRIA NO BRASIL: CAMPESINATO, AGRICULTURA FAMILIAR E AGRONEGÓCIO

A partir dessas análises, torna-se essencial discutir e desvelar todos os pseudodiscursos empregados no campo, como uma clara tentativa de destituir a maior arma detodas as comunidades visitadas: a capacidade de lutar. Apoiado na leitura desses espaços, terra e água ganham diferentes simbologias, concomitante ao processo de modernização e mecanização do/no campo, as marcas do cansaço na pele, o carimbo dapersistência desse povo, que se constrói e se reconstrói em suas múltiplas territorialidades, enquanto se confrontam com a latente apropriação do Estado e das empresas em parceria, desses detentores de capital que controlam as melhores terras e os recursos hídricos.

\section{CONCLUSÃO}

Como analisar a produção do espaço agrário sergipano entendendo os avanços e as amarras do capital? Qual a finalidade das estratégias do Estado juntamente com as empresas, ao concretizar um projeto que não soluciona o problema da pobreza da região? São indiscutíveisquestões acerca dessa problemática, tendo em vista o caráter predador do capital no espaço agrário.

No período de criação do referido projeto, a população ribeirinha, os que viviam nas terras ocupadas antes da instalação do Platô, àqueles que atualmente se confrontam com os interesses e ofensivas do capital, reivindicaram e reivindicam uma maior participação na divisão dos lotes, tendo em vista a realização de uma Reforma Agrária Popular tão urgente para a garantia da autonomia das comunidades.

A realidade refletiu a importância da terra e da água para o campesinato e para a subsistência de um povo. O que se constatou é a manutenção das relações de poder no espaço agrário do Baixo São Francisco, a partir do avanço das relações capitalistas de produção que tentam negar a luta histórica do campesinato e das comunidades tradicionais por sua permanência na terra, em um conjunto de municípios em que a pobreza é a marca mais gritante.

A nova lógica do capitalismo, em sua fase mais selvagem, é capturar o trabalho (concreto) e as riquezas naturais, para que assim o seu ciclo vicioso tenha 
êxito, mesmo que destrua direitos sociais, tais como o direito à alimentação, à moradia, ao acesso à terra e à água para a produção camponesa, mais saudável e produtiva, que pode propiciar um desenvolvimento socioeconômico pleno e concreto para estas famílias.

Por sua vez, o que se apreende e se reproduz no campo é o seu contrário, a presença daagricultura tecnificada, moderna, que utiliza água do Rio São Francisco para o enriquecimento de grupos empresariais, demonstrando dessa forma um novo reordenamento do espaço agrárioa serviço do capital, apoiado descaradamente pelo Estado, ampliam as expressõesda luta por terra na região, representada por trabalhadores e trabalhadoras exaustos de tantas perseguições e explorações.

Portanto, vislumbrar esta realidade nos obriga a ler a totalidade sem esquecer suas particularidades, sem dissociar das diferentes formas de resistências e existências no campo, ancoradas emvalores e coletividades na reprodução de um povo que se afirma enquanto luta num espaço-tempo de forças, apreendendo-se que os seres campesinos e ribeirinhos se reafirmam na defesa de seus territórios, territórios transbordados de práticas emancipatórias, memórias e de vida.

\section{REFERENCIAS}

ASCONDIR. Associação dos concessionários do distrito de irrigação Platô de Neópolis. Disponível em: http://www.ascondir.com.br/. Acesso em: 02 out. 2019.

CAMPOS, Christiane Senhorinha Soares. Pobreza e exclusão feminina nos territórios do agronegócio - O caso de Cruz Alta/RS. 2009. Tese (Doutorado em Geografia) - Universidade Federal do Rio Grande do Sul - UFRGS, Porto Alegre, 2009.

OLIVEIRA, Ariovaldo Umbelino de. A mundialização da agricultura capitalista no Brasil. In: OLIVEIRA, Ariovaldo Umbelino de. A Mundialização da Agricultura Brasileira. São Paulo: landé Editorial, 2016, p.123-390. 
SOUSA, Raimunda Áurea Dias. O agro-hidronegócio no vale do São Francisco: território de produção de riqueza e subtração da riqueza da produção. 2013. 356 f. Tese (Doutorado em Geografia) - Universidade Federal de Sergipe - UFS, São Cristóvão, 2013.

THOMAZ JR, Antônio. Degradação Sistêmica do trabalho no agrohidronegócio. Revista Mercator, Fortaleza, v. 16, e16020, 2017. Disponível em: http://www. mercator.ufc.br/mercator/article/view/2082. Acesso em: 21 out. 2019.

VASCONCELOS, Jordana Santana de Oliveira. Das Interfaces do Projeto de Irrigação Fruticultura Platô de Neópolis ao Agronegócio da Cana de Açúcar. 2015. Dissertação (Mestrado em Geografia) - Universidade Federal de Sergipe, São Cristóvão, SE, 2015.

\section{Entrevistas}

L. R.. Produção agrícola. Trabalho de campo [ago. 2019]. Entrevistadora: Mara Íris Barreto Lima.Neópolis, 1 arquivo, Transcrito. 2019.

M. A. S.. Comunidade Quilombola. Trabalho de campo [ago. 2019]. Entrevistadora: Mara Íris Barreto Lima. Brejo Grande, 1 arquivo, Transcrito. 2019.

M. I. S. S.. Comunidade Quilombola. Trabalho de campo [ago. 2019]. Entrevistadora: Mara Íris Barreto Lima. Brejo Grande, 1 arquivo, Transcrito. 2019. 


\section{CAPITULO 3}

\section{ESPAÇO AGRÁRIO, ASSENTAMENTO DO INCRA E PECUÁRIA: SE NÃO ERA PARA SER FAZENDA, TORNOU-SE FAZENDA DO MESMO JEITO ${ }^{1}$}

Mílvio da Silva Ribeiro João Santos Nahum

$1 \quad$ O artigo foi apresentado no XIV Encontro Nacional de Pós-graduação e pesquisa em Geografia - ENANPEGE, 2021, Grupo de Trabalho (GT 41), intitulado de "Dinâmicas globais do agronegócio na Amazônia e no Matopiba: escalas, conflitos e projetos" 


\section{INTRODUÇÃO}

Partimos da hipótese que a apropriação da terra, enquanto sucessões e coexistências, fundamenta a produção do espaço agrário na Amazônia paraense. Espaço agrário, assentamento e pecuária são termos com os quais se trabalha as compreensões de apropriação da terra nesse texto. Na dinâmica da pecuária bovina em Novo Repartimento-PA é importante observar como a terra é apropriada para a referida atividade. Assim, pensamos com Santos (SANTOS, 2009 [1996]5; 2014 [1988]), a concepção de sucessão e coexistência. No que concerne à expansão da pecuária na Amazônia, utiliza-se as formulações de (CHAPUI-POCCAR, 2014).

Na Amazônia paraense um assentamento tem a possibilidade de apropriação e distribuição de terra, diferente do que comumente se tem quando a terra é ocupada por criadores de gado. Porém, nos assentamentos do INCRA em Novo Repartimento, os lotes de terras de assentados têm se tornado em fazendas. $A$ compreensão da situação atual dos Assentamentos do INCRAé dada por sujeitos assentados que se tornam, trabalhadores das fazendas. Em Novo repartimento, o Espaço agrário e a política de assentamentos reverberam-se no lugar onde não era para ser fazenda, mas que foi transformado em fazenda.

O tema do presente artigo é a apropriação da terra de assentados do INCRA no município de Novo Repartimento-PA. Observa-se como são os processos de sucessão de apropriação da terra e como coexistem os sujeitos no espaço agrário. Os assentamentos do INCRA no município, a cada período, estão intrinsecamente relacionados com a pecuária bovina.

O estudo se faz necessário à geografia agrária, tendo como relevância o fato de refletirmos a relação de assentamento do INCRA à pecuária, a partir da expressão: "se não era para ser fazenda, se tornou fazenda do mesmo jeito". Trata-se de uma informação verbal de um sujeito que não conhece o agrário pela leitura acadêmica, mas pela vivência no processo de como ocorrem a apropriação da terra no município de Novo Repartimento-PA.

$5 \quad$ Ano da primeira edição da obra. 
A literatura tem discutido a concepção de uma Amazônia paraense como frente de expansão, frentes pioneiras, fronteira agrícola, dos grandes projetos, e, ainda como circuitos da economia da pecuária. A noção de apropriação da terra que se aborda, considera as perspectivas anteriores de como ocorrem os processos de sucessão de uso da terra, porém, na área do maior assentamento da América Latina denominado de Tuerê I e II situados em Novo Repartimento, instituída pelo Estado, para assentar na terra as pessoas que precisavam dela para trabalhar e produzirem a sua existência. Que apesar disso, passou a abrigar a pecuária bovina como a principal atividade econômica. A nível estadual, a produção da pecuária ocupa o segundo lugar no ranking de produção de bois. A área que consiste na localização sudeste do estado do Pará, há muito que havia sido vocacionada para produção de gado entre as influências, identificamos o programa Grande Carajás (PGC).

As vastas áreas de florestas, ainda que de assentamentos são objeto de apropriação e são destinadas para a pecuária. Assim, mostramos como são os mecanismos de uso que fazem com que a terra e floresta estejam objetivadas por forças motrizes. Tal força motriz, em nossa observação, é composta basicamente, por mercados de proteínas e grandes centros urbanos que dependem da produção de gado da Amazônia. Diante disso, o objetivo do trabalho é mostrar como se estruturam a dinâmica da pecuária bovina em Novo Repartimento-PA e como se dá o processo de apropriação de terras de assentados do INCRA. A metodologia consiste basicamente no levantamento da literatura pertinente ao tema, sem, contudo, exauri-la, seguindo-se de pesquisa de campo, tendo principal instrumento a observação e entrevistas semiestruturadas.

O foco do texto reside no fato de que o Assentamento do INCRA é uma forma de apropriação de áreas já consolidadas. Consolidar a terra na ideia do marco regulatório do meio ambiente de 2008, este regulamentado em 2012, o qual trouxe na sua letra, a recomendação de que todas as áreas já antropizadas fossem consideradas como áreas consolidadas (Portaria $n^{\circ} 28$ de 2008 e Lei $n^{\circ}$ 12.651 de 2012). 
Nesse aspecto, o assentamento é uma forma de sucessão do uso da terra. O outro ponto de vista é dado e obtido nas entrevistas em que as áreas são consolidadas, pelo mecanismo de corte e queima da florestada expressada da seguinte forma: "já fiz uma boa abertura, e meu pasto é novo". Nisso é demonstrado que a finalidade do uso da terra é para fazenda de gado. Em terceiro ponto, a predominância da paisagem se dá em forma de pastos, mas o fazendeiro diz: “aqui não há desmatamento, há pasto".

É nessa premissa que o texto está elaborado, com essa introdução, em seguida dos procedimentos metodológicos do trabalho. Na sequência indicamos os referenciais teóricos e conceituais do trabalho, à luz de categorias e conceitos. Posteriormente, apresenta-se os resultados e discussões do trabalho, mostramos a dimensão areal do município de Novo Repartimento-PA, representando as áreas de assentamentos do INCRA e discutimos o tema à luz de informações Instituto Nacional de Pesquisas Espaciais (INPE), dados do Instituto Brasileiro de Geografia e Estatística (IBGE), entre outros e sintetizamos em forma de gráfico o desflorestamento no município entre 2000 e 2019. Em seguida, como ponto principal dos resultados mostramos a partir de trabalho de campo os processos de sucessão de uso da terra, usando informações de atores entrevistados e finalmente mapeamos a sucessão e o uso da terra nos assentamentos identificando os principais alertas de incêndio nas áreas de assentamento do INCRA, até junho de 2021. Em última elaboração, apresenta-se a considerações finais. Em síntese, os dados confirmam que onde não era para ser fazenda tronou-se fazenda do mesmo jeito.

\section{METODOLOGIA}

Metodologicamente a pesquisa tem como contexto de sua realização o município de Novo Repartimento-PA, situado na porção sudeste do estado do Pará com uma área territorial de $15.398,723 \mathrm{~km}^{2}$ (IBGE, 2010). As primeiras observações revelam as paisagens no espaço agrário formadas predominantemente por pastagem. Conforme o Instituto Nacional da Colonização e Reforma Agrária (INCRA, 2018), o município de Novo Repartimento-PA, comporta 35 as- 
sentamentos em parte de sua área territorial, dimensionada em 5.723,4453 Km², dentre eles, está um dos maiores da América Latina, o Tuerê, com 2.408,955 km² de extensão.

A pesquisa abrange o período de 2019 a 2020, com trabalhos de campo, primando-se especialmente, por observações e entrevistas, no que se refere aos sujeitos entrevistados, esses por cuidados, não permitiram o uso de seus nomes, e por isso, identifica-se por numeração. O objeto da pesquisa é caracterizado, essencialmente, na captura do entendimento do espaço agrário, considerando de um lado os assentamentos do INCRA, a condição dos assentados, e sobretudo, como as terras de assentados são apropriadas pelos fazendeiros.

As coletas dos dados foram realizadas a partir de literaturas levantadas, com as quais situamos a pecuária e o seu desenvolvimento em Novo Repartimento-PA e como as florestas são transformadas em pastagem. Para pensar a dimensão da paisagem no espaço agrário primamos pela observação em trabaIho de campo. Assim, considera-se que, "a primeira atividade científica é a observação de fatos" (SEVERINO, 2007, p. 103). A observação conduz à reflexão, de modo que é o estágio final do processo de conhecimento, momento em que sujeito e objeto fundem-se (VITTE, 2007). Conforme Christofoletti (1985), a observação é instrumento de análise, que se produz na forma de saberes e se fundamenta por reflexão e reinspeção das coisas antes observadas, e que por via da experiência adquirida da intimidade destas observações vem a comparação e a síntese.

A análise de dados considera o assentamento do INCRA, florestas, apropriação da terra e fazendas de gado. As informações foram examinadas à luz da literatura, das observações, dos dados levantados e em consideração à metodologia. Nesse sentido, que os procedimentos de análises triangularam dados de campo, observação e as concepções teóricas. De modo que com isso foi possível traduzir que uma área que não era para ser fazenda do ponto de vista da sua criação institucional, tornou-se em fazenda. 
A QUESTÃO AGRÁRIA NO BRASIL: CAMPESINATO, AGRICULTURA FAMILIAR E AGRONEGÓCIO

\section{REFERENCIAL TEÓRICO}

As formulações referentes à concepção de sucessão e coexistência, são de (SANTOS, 2009; 2014), usadas para o entendimento de espaço agrário quanto ao uso e apropriação da terra. Ao se considerar as múltiplas determinações em virtude da pecuária bovina, e essa em forma de sucessão e coexistência de ações, é que o espaço agrário se configura como uma categoria política e, distingue-se de meio rural, espaço rural ou campo.

Sucessão e coexistência de política e espaço resultam em dinâmicas agrárias no município de Novo Repartimento. Considera-se que políticas de planejamento regional não têm em si, a sua força de uso da terra, mas tem como ponto de partida os interesses exógenos ao lugar (mercado e consumo).

A apropriação da terra na Região de Integração do Lago de Tucuruí é explicada na lógica de uma situação geográfica de sucessão e coexistência de ações no lugar, como a construção da UHE de Tucuruí e os eventos organizacionais como a produção de energia e distribuição via linhões de transmissão de energia para atender interesse exógeno ao lugar.

Considera-se que espaço agrário seja caracterizado por variáveis resultantes de sucessões e coexistências, não lineares, e, constitui-se tanto por materialidade quanto por imaterialidade, mas que o torna singular, a apropriação da terra (NAHUM, 2019; SANTOS, 2009).

Neste raciocínio, o espaço agrário de Novo Repartimento, que antes, estava simplesmente como espaço e natureza, foi aprendido pela política e a partir daí a natureza passou a ser socializada, visto que "é na esfera política e nas relações de poder que encontramos o sentido da distribuição dos sistemas de energia, transporte, comunicação, informação, abastecimento, dentre outros que assumem a forma de objetos geográficos pelo espaço" (NAHUM, 2019, p. 27)

Rememorando o Plano de Valorização Econômica da Amazônia (SPVEA) criado pela Lei 1.806/1953. Os argumentos da SPVEA giraram em torno de: ocu- 
pação territorial, construção de sociedade econômica e o seu desenvolvimento para cumprir uma função de subserviência ao Brasil. Tais argumentos são elaborados a fim de assegurar a ocupação e uso territorial da Amazônia como se fosse espaço sem gente, onde os planos de desenvolvimento da Amazônia, como sempre, refletem a personificação da ideia de região tão somente oculta os interesses que presidem, sustentam e estruturam. (NAHUM, 2012).

Para Chapui-Poccar, (2014), a concepção da pecuária na Amazônia discutida como circuitos econômicos e o desenvolvimento de frentes pioneiras. A pecuária é oriunda dos interesses do mercado e consumo, objetivadas no plano de suposto desenvolvimento de uma região, em seguida se transforma em fazenda, essas se resumem como diz Veiga, et. al (2004) a ideia de expansão e trajetória da pecuária na Amazônia. Trajetória que pensamos não apenas na distribuição especial da pecuária em áreas da região, mas em uma escala de mundo. Como é elaborado por Martins (1996) que o tempo da fronteira, é como um retorno a controvérsia sobre a frente de expansão.

A propriedade da terra é um obstáculo à expansão das relações capitalistas de produção, não porque o proprietário deva necessariamente converter-se em burguês, em capitalista, mas porque, como dizia Marx, a propriedade da terra, na figura do proprietário, ergue-se diante do capital para cobrar um tributo, para cobrar uma renda, sem o que esse capital não poderá expandir-se na agricultura e dominar o trabalho no campo. O proprietário da terra não uma figura de fora do capitalismo, mas de dentro. (MARTINS, 1981, p. 170) grifo do autor.

É a partir desses autores que se elabora as compreensões da relação da pecuária e os assentamentos em Novo Repartimento-PA.

\section{RESULTADOS E DISCUSSÃO}

De imediato destaca-se a paisagem do espaço agrário de Novo Repartimento caracterizada, predominantemente, por pastagem. O segundo dado é conforme o Instituto Nacional da Colonização e Reforma Agrária (INCRA, 2020), o município de Novo Repartimento-PA, comporta 35 assentamentos em parte de 
sua área territorial, dimensionada em $5.723,4453 \mathrm{Km}^{2}$, dentre eles, está um dos maiores da América Latina, o Tuerê, com 2.408,955 km² de extensão.

Tem-se os assentamentos Tuerê, Rio Gelado, Sagitário, Redenção, José Martins Pessoa, Cocalãndia, Jaguatiara, Manuelito, Serra Quebrada, Santa Amélia, Cigana, São Gabriel, Pajeú, Santa Izabel, Mineiro Preto, Alto Pacajá, Boca Larga, Jacaré-açu, José Cirilo Gomes, Rio Preto, Santa Maria, Santa Liduina, Iolanda, Alto Amazonas, Cachoeirinha, São Geraldo Do Repartimento, Nossa Senhora Da Guia, Vale Do Aratau, Cocalândia II, Sunil, Jordão, Carajás, Monte Das Oliveiras, Cachimbão, Água Da Saúde.

Os dados do INCRA informam que a capacidade de famílias no assentamento é de 8.817, e desse total, 7.839, já foram assentadas (MAPA, 2021). Os assentamentos foram constituídos originalmente por famílias organizadas pelo movimento dos trabalhadores rurais sem-terra (MST), dos sindicatos e da comissão pastoral da terra. A seguir o mapa 1, a localização dos assentamentos do INCRA, que totalizam 376768,1 ha, desse total 102578,1 ha e a dimensão areal do Assentamento Tuerê I e II.

Mapa 1: Localização dos assentamentos do INCRA em Novo Repartimento-PA

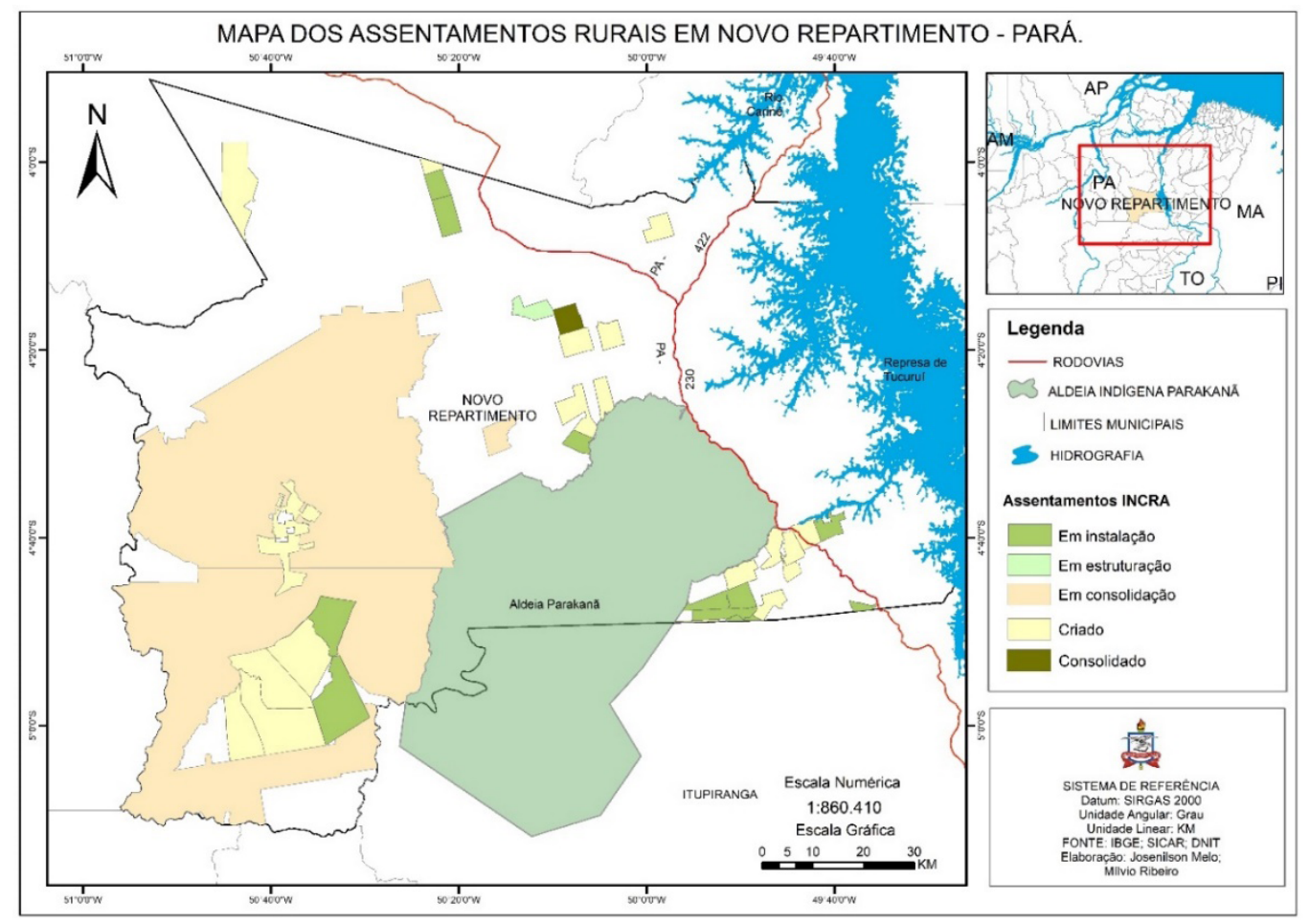

Fonte: IBGE; SIRGAS; DENIT, 2020 
A QUESTÃO AGRÁRIA NO BRASIL: CAMPESINATO, AGRICULTURA FAMILIAR E AGRONEGÓCIO

Registram-se, entre os assentados, famílias sobreviventes do massacre da Curva do "S" na BR 155, em Eldorado dos Carajás em 1996, no qual 21 pessoas foram tombadas pela Polícia Militar (PEREIRA, 2020). Esse episódio marca uma geografia da Amazônia paraense de transição como expressão da luta de classes no estado do Pará, onde os comandos (forças exógenas) ao lugar determinam o modus operandi de apropriação dos trabalhadores rurais no contexto da luta pela terra.

Nos assentamentos de Novo Repartimento, as famílias sobreviventes do massacre de Eldorado dos Carajás em 1996 foram realocadas pela pastoral da terra para uma área da união, à $100 \mathrm{~km}$ de distância da sede do município, localizado no Assentamento Carajás, as margens do Rio Pacajá. As famílias permaneceram acampadas por algum tempo, até o INCRA do município de Tucuruí demarcar o assentamento e inseri-las na Relação de Beneficiários (SILVA; RIBEIRO, 2017).

Das paisagens do assentamento, como dos outros locais no espaço agrário do município, são marcadas por pastos para a criação de gado, onde as cercas de arame sinalizam limites entre grandes fazendas. Nessas fazendas a metamorfose é que as terras dos lotes do INCRA foram apropriadas por usos diferentes aos que caracterizam a política de reforma agrária, repercutindo a maneira como a produção do espaço agrário ocorre. Silva; Ribeiro (2017) afirmam que, "durante implantação do Projeto de Assentamento Tuerê, ocorreram sucessivas invasões sob o comando de lideranças político-partidárias". Tais percepções dos moradores do lugar, ocorrem em virtude da existência de madeiras nobres, o que influenciou aberturas das vicinais provisórias para retirá-las, em seguida, o desflorestamento, aliado à plantação de capim para formação de pastos, mas é apenas a ponta de um "iceberg", pois, as pressões são oriundas de grandes comandos, promovido no âmbito da política exógena ao lugar.

No município de Novo Repartimento a extensão territorial, localização e produção de bovinos associada ao mercado exportador são fatores que impulsionam a apropriação da terra. Nesse sentido, a distância entre esse município e 
Belém-PA (capital do estado do Pará) é de $441 \mathrm{~km}$, e até o porto de Barcarena-PA é cerca de $428 \mathrm{~km}$. Situamos o município com relação ao porto de Barcarena, por ser um dos grandes produtores de gado e está relativamente perto dele. $\mathrm{O}$ porto movimenta significativo embarque de bois vivos para abastecer o mercado de proteína animal em escala internacional.

Isso é observado por Poccar-chauir (2004, p. 30) quando escreve que "Nas frentes amazônicas, a indústria de carne bovina compreende diretamente os mundos dos produtores de gado vivo, transportadores, comerciantes de gado vivo, abatedouros, atacadistas de carne bovina e distribuidores de varejo". Nesse sentido, tem-se que as forças motrizes (mercado e consumo) mais o balizamento institucional e jurídico dados pelo Estado com os promotores da produção de gado na Amazônia Paraense, por conseguinte, são os responsáveis pelo desmatamento na Amazônia, porém, não são localizados no âmbito das jurisprudências como culpados.

A relação entre o consumo de proteína animal e o desmatamento pode ser observada em dados do Programa de Monitoramento da Floresta Amazônica Brasileira (PRODES) de toda extensão territorial de Novo Repartimento, tem-se que, até o ano de 2000, foram desmatadas uma área de $3.105 \mathrm{~km}^{2}$, equivalente a $20,1 \%$. Nesse período, iniciou-se, no Brasil, o Programa Avança Brasil estimulou o avanço da agropecuária no município.

Observa-se o registro elevado de desflorestamento até 2019, apesar da incorporação dos incrementos de florestas realizados no município, só restam $38.85 \%$ de floresta. Em duas décadas, foram desmatados $9.432 \mathrm{~km}^{2}$, correspondendo a $61,82 \%$ da área total do município. (PRODES, 2019).

Segundo o IBGE, (2017, Censo Agropecuário) da dimensão areal do município de Novo Repartimento, 8.652,31 km² são ocupados por estabelecimentos agropecuários, desse total, 5.743,06 km² são de pastagens, deve-se considerar que esses dados são do ano de 2017, e isso sugere que já tenha sido ampliado a área de uso para a pecuária. 
A QUESTÃO AGRÁRIA NO BRASIL: CAMPESINATO, AGRICULTURA FAMILIAR E AGRONEGÓCIO

Os dados extraídos do INPE (2020) no âmbito do PRODES (2021), no gráfico 01 , a seguir, esclarecem que o desflorestamento no município acompanha a evolução ou implantação das políticas públicas no Brasil, situando-se os Planos plurianuais dos grupos no poder do mesmo período. As ações dos grupos no poder com concepções distintas, a tendência de uso da terra, e das florestas se materializaram numa escala de crescimento semelhante. Primeiro, observa-se que até o ano 2000 o acúmulo de desflorestamento na área é de $3.105 \mathrm{~km}^{2}$, e a existência de $11.157 \mathrm{~km}^{2}$ de área com florestas naturais, porém a partir do ano 2000 o desflorestamento é ascendente, em menos de vinte anos, a uma inversão, pois o total de floresta natural é próximo do que em 2000 era de desflorestamento.

Como discussões, consideram-se que além dos objetos geográficos como as estradas federais, BR 230 (Transamazônica), a BR 422 (Transcametá), usinas hidrelétricas como a de Tucuruí-PA que impulsionaram a apropriação da terra, desmatamento e criação de gado nessa porção da Amazônia Paraense, mais as políticas de incentivos fiscais e de créditos no âmbito dos programas de governos proporcionaram as condições ideais para fazer avançar as fazendas de gado sobre as florestas. Nesse sentido, os objetos geográficos como as estradas e a usina hidrelétrica são componentes resultantes das políticas instituídas nos planos e programas para favorecer os usos do território. E, posteriormente, como uma espécie de ponto de partida do que viria ser essa área geográfica, como produto da relação entre política e espaço agrário, ter-se-ia como a grande influenciadora à frente de expansão da pecuária.

Partindo dos dados do INPE/PRODES no de 2004, a área desmatada de Novo Repartimento cresceu para $4.986 \mathrm{~km}^{2}$, equivalente, a $32.3 \%$ de todo o território. Em 2007, a área de desflorestamento mapeada chegou a $6.006 \mathrm{~km}^{2}$, o que corresponde a 38.92\% (INPE/PRODES, 2007). Em 2010, cerca de 7.002km² foram desmatados, totalizando $45.37 \%$ da área do município. Em 2013, o crescimento do desmatamento subiu para $7.455 \mathrm{~km}^{2}$, e chegou a $48.31 \%$ da área de florestas extintas. Em 2016, o desmatamento já atingiu $7.831 \mathrm{~km}^{2}$ ultrapassando mais da metade de todo o território, chegando em torno de $50.75 \%$ da área des- 
matada. Em 2019, atingiu-se a marca de $8.267 \mathrm{~km}^{2}$ de áreas de florestas desmatadas, atingindo o percentual de 53.58\%. (dados do PRODES, entre 2007 e 2019).

Segundo o PRODES, na tabela a seguir, tem-se o monitoramento do nível de desmatamento em Novo Repartimento-PA entre 2000 e 2019.

Gráfico 1 - Desflorestamento em Novo Repartimento entre 2000 e 2019

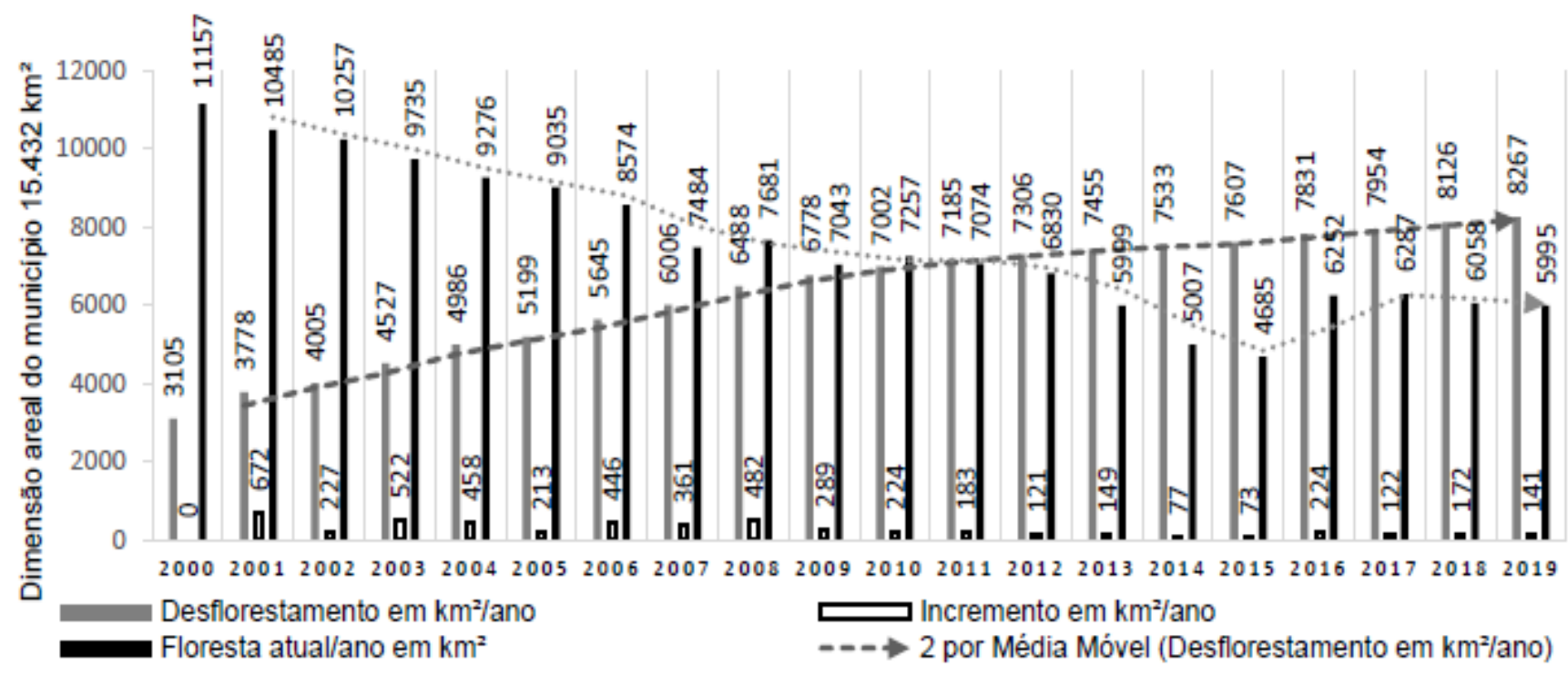

Fonte: PRODES - http://www.dpi.inpe.br/prodesdigital/prodesmunicipal.php (2000 a 2019)

Para conferir o desflorestamento e sua substituição por pastagem, percebeu-se que a paisagem na área é composta por pastos, cercas, vicinais e tranqueiras, entre outros. Em itinerário de um dos trabalhos de campo, partiu-se da sede do município de Tucuruí, seguindo a BR 422 (Transcametá), na direção da sede de Novo Repartimento-PA, a $70 \mathrm{~km}$ de distância. O tempo de viagem, em estrada de chão, é em torno de uma hora e trinta minutos, onde foi feito o primeiro ponto de localização. A partir daí, seguiu-se a BR 230 (Transamazônica), até a Vila Pacajá/Novo Repartimento-PA, a 106km com relação a sede do município, situado na localização, 4 8' 48" S; 50¹3'11" W.

Nesse trajeto, as observações trouxeram à memória lembranças do que a literatura e os dados oficiais reportam acerca do fato de o município ser reconhecido pela grande produção de gado bovino. A paisagem da estrada é marcada por 
bois pastando, cercas de arame, porteiras, tranqueiras e essas, como sinônimo de apropriação da terra e expressam o "proibido entrar[...] propriedade privada", pois, por detrás delas, encontram-se as sedes das fazendas, no sentido expressivo do domínio da frente de expansão, como "realidades sociais substantivas, modos singulares de organização da vida social, de definição dos valores e das orientações sociais (MARTINS, 1996, p. 29).

Adentrando as áreas de assentamento, a partir da Vila Pacajá/Novo Repartimento-PA, a trajetória foi seguir a estrada de acesso ao Assentamento Tuerê I e II, com parada no cruzamento da estrada do Rio Gelado no ponto (4 $22^{\prime} 12^{\prime \prime}$ S; $\left.50^{\circ} 19^{\prime} 19^{\prime \prime} \mathrm{W}\right)$, o ponto seguinte foi na vicinal 2 do Tuerê ( $4^{\circ} 21^{\prime} 48^{\prime \prime}$ S; $50^{\circ} 26^{\prime} 45^{\prime \prime}$ W).

As apreensões do assentamento Tuerê revelam a proatividade quanto à dimensão espacial, ao se encontrar as pessoas, e quando era possível estabelecer diálogos com elas, obteve-se as expressões: "A pecuária é boa. A gente ganha com ela e não tem outra renda melhor, ainda mais agora[...] ( $N^{\circ} 01,2020$, informações orais). Na fala, "ainda mais agora" o interlocutor está se referindo aos preços praticados na venda e compra de boi nas fazendas, no ano de 2020.

O assentamento não responde aos objetivos da política que o instituiu, mesmo que se encontre ainda algumas pessoas assentadas na área, por exemplo, na localização da vicinal 3, na qual, ainda se tem presente a cultura de cacau, encontrou-se um senhor (Entrevistado $n^{\circ} 02$ ) que relatou ser natural do estado do (PA). Quando questionado acerca da relação entre o pequeno (agricultor/pecuarista/assentado) e o grande fazendeiro, disse: "Não tem conflito na minha área de moradia. Aqui tá manso agora, já foi mais complicado, aqui".

A pecuária toma conta do assentamento sufocando a esperança dos que vieram para o lugar alimentados pelo sonho de ter um lote de terra para trabalhar e produzir a vida. O entrevistado salientou que sua vinda para tal localização se deu em virtude de aquisição de terra. Esse comprou 50ha inicialmente, e, posteriormente adquiriu mais 100ha. Nas palavras desse pequeno pecuarista, é dito, 
"que não há trabalhadores suficiente para os trabalhos da pecuária, principalmente, os trabalhos da juquira".

A dinâmica migratória revelada por meio das informações orais colhidas revela o processo de imigração de outros estados em relação ao estado do Pará ou de outros municípios deste. A motivação sempre indica que é a aquisição de mais terras, para praticar a pecuária, pois de onde vieram não a tinham ou não era suficiente para criar gado. De modo que, no Assentamento Tuerê, foi encontrada terra suficiente ou de fácil aquisição para tal atividade. "aqui, [vicinal 3, do Tuerê I], já fiz uma boa abertura, e meu pasto é novo". Nesse fragmento, está claro que o desmatamento é recorrente. Entretanto, o entrevistado parece ter recorrido a uma retórica de justificativa quando diz: "aqui não há desmatamento, há pasto”.

As atividades do pequeno pecuarista dão-se em sua própria área, ou ele dar de meia ('meia' é expressão que se usa para qualificar a forma como desenvolve a pecuária, criando gado de outro pecuarista ou dando gado a este). A expressão "aqui há pasto" segundo o entrevistado, significa "já é área com bastante tempo que estão preparadas" (Entrevistado, $n^{\circ} 03$ ). Isso, traz ao debate o fato que se estruturou no âmbito do chamado Marco legal da proteção florestal no Brasil, fundamentada na Lei $n^{\circ}$ 12.651, de 25 de maio de 2012, conforme entendimento dado pela lei, essas áreas, mesmo tendo passado por fortes transformações antrópicas, são consideradas, consolidadas, o que é legitima o desmatamento até a presente data.

No mapa 2 temos os focos de desmatamento até o mês de junho de 2021. A partir dele é possível notarmos que a principal incidência de incêndio ocorre sobre as áreas dos assentamos do INCRA. No mapa os dados são separados: a primeira representação à direita superior representa o tracejado numeroso de vicinais no interior do município, no segundo dado, são representadas as alertas de desmatamento correspondentes entre 50 e 100(ha). O terceiro dado é a representação do desmatamento correspondentes de 100 a 852 (ha) sobre o qual é verificada a maior concentração de desmatamento. 
Mapa 2. Mapa de alertas de desmatamento até junho de 2021

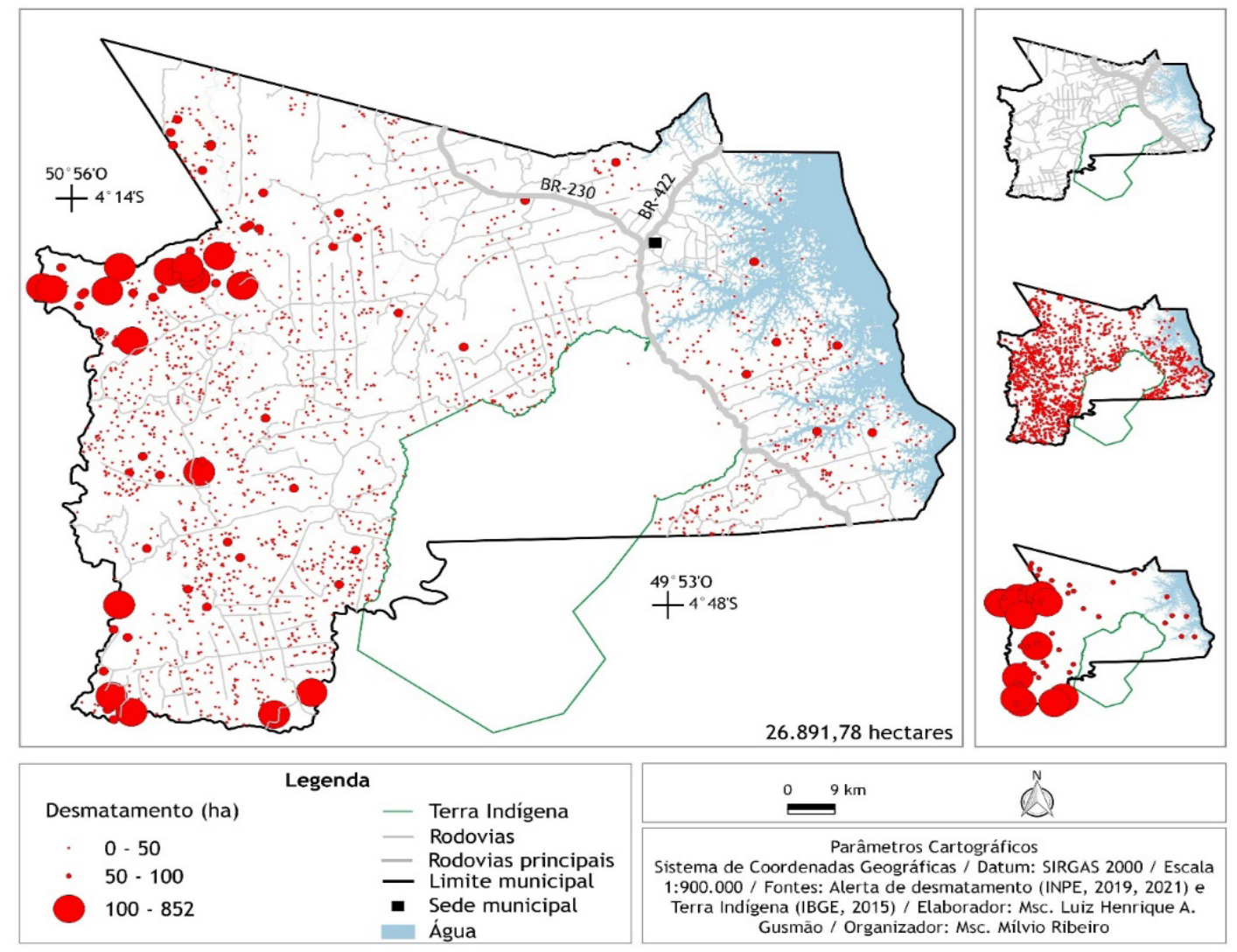

Fonte: INPE (2019-2021); Mapbiomas (2021). Link: https://alerta.mapbiomas.org/

As representações de alerta de desmatamento são até o final de junho de 2021. Nas direções Oeste e Sudoeste estão as maiores concentrações de alerta de desmatamento que, coincidem com a terra dos Assentamentos do INCRA. Na direção norte do mapa, atualmente não são representados alertas atuais de desmatamento, mas são áreas localizadas nos corredores das BR 230 (transamazônica) e BR422 (Transcametá) que já foram consolidadas em termos de ocupação com a pecuária e outras formas de uso. Na porção Leste, localiza-se o lago da Hidrelétrica de Tucuruí, área com uma Unidade de Conservação abrangendo $222.072,64$ (ha) representa $39,18 \%$ do total de 1.539.871,60(ha) da área do município. Nessa área tem havido a incidência de desmatamento.

A única área no mapa que ainda consta preservada é a terra da etnia Parakanã, na porção Sul. Mas que, na qual, há á indício de alertas de desmatamento. O avanço do desmatamento está associado às políticas de Estado, a cada tempo a ampliação da pecuária é ligada aos planos plurianuais dos governos no 
A QUESTÃO AGRÁRIA NO BRASIL: CAMPESINATO, AGRICULTURA FAMILIAR E AGRONEGÓCIO

poder. À medida que há pressão causada pela pecuária no espaço agrário, novos estados naturais são criados e o resultado disso se evidencia como impactos sobre a população da área.

Outros aspectos são extraídos do mapa é que o cenário de desmatamento do qual Novo Repartimento acompanha a mesma perspectiva do município de São Felix do Xingu-PA, ao qual é limítrofe na porção de sua área. São Felix do Xingu-PA tem o maior índice de desmatamento, e por isso também é o maior produtor de bovinos no Brasil. Atividade que ali nascem no bojo do Grande Projeto Carajás. É a partir daí, que Novo Repartimento vai ser dinamizado como um dos grandes produtores de gado do Brasil. Assim, junto com outros municípios são listados como os de maiores incidência de desmatamento.

Essas são as apreensões que se tem do estudo, "onde não era para ser fazenda, tornou-se fazendo do mesmo jeito é corroborado na comparação dos dois mapas apresentados no texto. No mapa um, mostramos a localização dos Assentamentos do Incra. Sobre os assentamos, identificamos como ocorrem a sucessão da apropriação da terra, suma síntese afirma-se que as áreas eram de posseiros, foram repatriadas pelo INCRA e distribuições para os assentados, esses por conta da chegada dos fazendeiros, compraram os lotes dos assentados e o que era lote de terra de assentamentos tornaram-se fazendas. No mapa dois, os principais focos de incendia coincidem com as áreas dos assentamentos do INCRA. As distribuições dos maiores focos de Incêndio, isto é, queimadas na floresta são localizadas na direção Oeste e Sudoeste. É preciso considerar que nas outras áreas representadas no mapa, a incidência de focos de Incêndio não se dá na mesma proporção, pois já as consideram como áreas consolidadas.

\section{CONSIDERAÇÕES FINAIS}

Em Novo Repartimento a terra é objeto de posse que se dá em forma de sucessão e coexistência. A terra passa por apropriações, em que um dia eram terras devolutas do Estado, que foram ocupadas por posseiros sob várias possibilidades. Em seguida, a terra, torna-se novamente objeto de uso do próprio 
Estado, e esse a distribui a assentados, os quais, por sua vez, passam a compor um território onde o fazendeiro é que tem poder para uso da terra.

Os sujeitos que outrora assentados coexistem com os fazendeiros, mas, como subservientes das fazendas, porém sem a posse da terra, pois elas já foram incorporadas às fazendas. As fazendas compõem as paisagens dos assentamentos. Elas foram construídas sob a forma de pressões e expressam a forma e o conteúdo do espaço agrário. Reúnem-se no processo de sucessão e coexistência. O dinheiro, a terra, a política, o sonho pela terra, o sonho de ser fazendeiro, o medo, o conflito que geram a norma. A norma do estado que se metamorfoseia em números. Os números não dizem muito, porque escondem a face real.

O texto foi construído com introdução, com procedimentos metodológicos do trabalho, com os referenciais teóricos e conceituais e os resultados e discussões do trabalho. De modo geral, mostramos a dimensão areal do município de Novo Repartimento-PA, mapeamos de modo específico as áreas de assentamentos do INCRA, e discutimos o tema à luz de informações INPE, dados do IBGE, entre outros e sintetizamos em forma de gráfico o desflorestamento no município entre 2000 e 2019. Identificou-se que os processos de sucessão de uso da terra, dão-se em forma de compra e venda, da grilagem, do assédio dos grandes fazendeiros aos pequenos produtores e assentados. As práticas que corroboram a forma de ocupação são mostradas no texto a partir dos alertas de incêndio nas áreas de assentamento do INCRA, até junho de 2021. E, a síntese revelada nos dados confirma a fala de um entrevistado, que diz: "onde não era para ser fazenda, tronou-se fazenda do mesmo jeito".

Considera-se que da apropriação a terra em Novo Repartimento está em pleno vigor, visto que, as políticas de Estado, especificamente, com os grupos no poder são assediadas pelos mercados e grandes centros, e assim, legitima as áreas de terra na Amazônia para a produção de commodities, inclusive nas áreas de assentamentos do INCRA. Pondera-se que o artigo tem limites no que tange 
a uma expressão conclusiva do tema. Pois muito se tem a explorar, já que, a expressão da pecuária em novo Repartimento não decorre de um único interesse. O que outras incursões de pesquisa poderão mostrar, sendo assim, esse texto pode ser desdobrado em uma agenda de pesquisa.

\section{REFERENCIAS}

BRASIL. Lei $\mathbf{n}^{\circ} \mathbf{1 2 . 6 5 1}$, de 25 de maio de 2012. Institui o novo código florestal brasileiro.

CHRISTOFOLETTI, Antônio. As perspectivas da nova geografia. In: Perspectiva da geografia. Antônio Christofoletti (org.). - Campus de Rio Claro: $2^{\mathrm{a}}$ ed. Difel, 1985.

INSTITUTO DE PESQUISAS ESPACIAIS - INPE. Terrabrasilis/PRODES Disponível em: http://www.dpi.inpe.br/prodesdigital/prodesmunicipal.php. Acesso em: 28 Dez de 2020.

INSTITUTO BRASILEIRO DE GEOGRAFIA E ESTATÍSTICA - IBGE. Censo agropecuário, 2017. Série histórica. Disponível em: https://www.ibge.gov.br/estatisticas/economicas/agricultura-e-pecuaria/21814-2017-censo-agropecuario. html?edicao=25743\&t=series-historicas. Acesso em: 05 mar. 2021.

INSTUTO NACIONAL DE COLONIZAÇÃO E REFORMA AGRÁRIA - INCRA. Sistema Nacional de Cadastro Rural (SNCR), 2018. Disponível em: < http:// www.incra.gov.br/maraba> Acesso em, 01 de jun de 2019.

MAPA - Ministério da Agricultura, Pecuária e Abastecimento. Projetos de Reforma Agrária Conforme Fases de Implementação Nome do Projeto. 2021. Disponível em: file://C:/Users/M\%C3\%ADlvio/Dropbox/PC\%20(2)/Downloads/ assentamentosgeral.pdf. Acesso em 15 nov 2021.

MARTINS, José de Souza. O tempo da fronteira. Retorno à controvérsia sobre o tempo histórico da frente de expansão e da frente pioneira. Tempo Social; Rev. Sociol. USP, S. Paulo, 8(1): 25-70, maio de 1996.

NAHUM, J. S. <b>Região, discurso e representação: a Amazônia nos planos de desenvolvimento</b\&gt; - doi: 10.4025/bolgeogr. v29i2.11001. Boletim de Geografia, v. 29, n. 2, p. 17-31, 20 abr. 2012. 
POCCARD-CHAPUIS, $R$. Les réseaux de la conquête: rôle des filières bovines dans la structuration de l'espace sur les fronts pionniers d'Amazonie orientale brésilienne. Paris: Universe de Paris X - Nanterre, 2004. 435 p. + annexes. Thèse de doctorat engéographie.

SANTOS, Milton. Espaço e Método. 5. ed. 2. reimp. São Paulo: Edusp, 2014[1985].

SEVERINO, Antonio Joaquim. Metodologia da Pesquisa. 23. ed. ver. Atual. São Paulo: Cortez, 2007.

VEIGA, J. B, et.al. Expansão e trajetória da pecuária na Amazônia: Pará, Brasil / Jonas Bastos da Veiga (el. al.]. - Brasília: editora Universidade de Brasília, 2004.

VITTE, Antonio Carlos. O desenvolvimento do conceito de paisagem e sua inserção na geografia física. Mercator - Revista de Geografia da UFC [en linea]. 2007, 6 (11), 71-78 [fecha de Consulta 18 de Febrero de 2021]. ISSN. Disponível em: https://www.redalyc.org/articulo.oa?id=273620627008. Acesso em: 26 dez. 2020. 
doi $10.48209 / 978-Q R-89949-04-6$

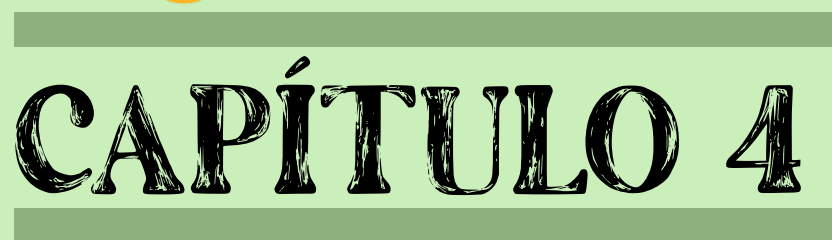

\section{NOTAS SOBRE 0 AGRONEGÓCIO DA PIMENTA EM SERGIPE: TERRA E TRABALHO SOB DOMINAÇÃO DO CAPITAL}

Tiago Barreto Lima Josefa de Lisboa Santos Bruno Andrade Ribeiro 
RESUMO: O Agronegócio é entendido, na presente pesquisa, como uma interrelação entre o capital industrial e financeiro no campo, a partir da subordinação da terra e do trabalho; devendo ser distinguido da agricultura capitalista e dos complexos agroindustriais (CAls). Esse modelo de produção, subsiste a partir da substituição de trabalho vivo por trabalho morto, através de um processo concomitante de especialização da força de trabalho, no manuseio de distintos aparatos tecnológicos e precarização contínua, com a presença de trabalhadores em situações similares à escravidão nos latifúndios produtores de commodities, em grande medida. Nesse sentido, a fundamentação teórica contribuiu para o entendimento de que, a partir da década de 1990, com o advento do neoliberalismo no Brasil, a integração entre o capital agrário, industrial e financeiro adquire os contornos do que se entende como o agronegócio enquanto modelo hegemônico de produção. Com o discurso de desenvolvimento e progresso para as regiões, o que se assiste é um processo de expansão da pobreza e miséria no campo brasileiro. Nesse sentido, o presente trabalho analisou os rebatimentos socioambientais da expansão do agronegócio da pimenta no estado sergipano, sobremodo, nos municípios de Itabaiana e Lagarto, bem como buscou explicar a relação entre a expansão da pimenta nos referidos municípios e o destino da terra para a produção e os nexos causais entre produção de pimenta em Sergipe e adoecimento do trabalhador. A pesquisa adotou uma abordagem quanti-qualitativa, considerando a área ocupada pelos empreendimentos produtores de pimenta, quantidade e valor de produção, número de produtores; e qualitativa, observações in loco e entrevistas estruturadas com grupos focais. Desse modo, a produção de pimenta nos municípios de Lagarto e Itabaiana em Sergipe pode ser desvelada a partir de elementos que consideram a dimensão mundializada do capital: a expansão de monopólios territoriarizados em terras camponesas, cujo exemplo do Grupo Maratá é emblemático no quadro do campesinato sergipano. Quanto a subordinação dos trabalhadores e trabalhadoras do campo, observou-se que o agronegócio da pimenta é responsável pela destituição da autonomia camponesa, com a substituição da produção de alimentos para a imposição do então produto a ser manufaturado pelo conglomerado agroindustrial.

\section{INTRODUÇÃ $0^{6}$}

O presente artigo versa sobre os rebatimentos na produção do espaço agrário decorrentes do agronegócio da pimenta. O ponto de partida para a con-

6 O presente trabalho versa sobre as considerações finais do Projeto de Iniciação Científica (PIBIC/UFS/CNPq) - PIE9492-2020 - Expansão do Cultivo de Pimenta em Sergipe e Rebatimentos na Produção do Espaço Agrário, correspondente ao edital n. ${ }^{\circ}$ 01/2020 COPES/ POSGRAP/UFS. A referida pesquisa corresponde ao plano de trabalho 'Estudo Sobre o Cultivo de Pimenta em Sergipe'. Foi primeiramente apresentado e publicado no VI ENGPECT e XII Fórum Estado, Capital, Trabalho - 31 de AGOSTO a 03 de SETEMBRO de 2021 - UFS Campus São Cristóvão. 
secução da pesquisa foram os Perímetros Irrigados Jacarecica I e Piauí, nos municípios de Itabaiana e Lagarto, respectivamente, no estado de Sergipe.

Para tal, objetiva-se explicar a relação entre a expansão da pimenta nesses municípios e o destino de área para a produção de alimentos; bem como, discutir os nexos causais entre produção de pimenta em Sergipe, condições de trabalho e adoecimento do trabalhador (THOMAZ JUNIOR, 2009; 2017; 2018). Ao longo das entrevistas aos trabalhadores e trabalhadoras, debruçou-se no entendimento sobre as mudanças oriundas da expansão do agronegócio em diferentes regiões do país, sobremodo, no estado de Sergipe, a partir do agronegócio da pimenta.

A realidade do trabalho nas produções de pimenta desvela um panorama de precariedade social na reprodução de relações não-capitalistas de produção sob o signo da subordinação capitalista (OLIVEIRA, 2016). Para além da expropriação da terra, substrato fundante da vida humana, o capital se vale dos mecanismos de subordinação da força de trabalho e da renda camponesa, através das associações existentes entre Estado e capital financeiro (CAMPOS, 2011; DELGADO, 2016).

A fertilidade do solo somada à disponibilidade hídrica do Perímetro Irrigado do Rio Piauí e do Perímetro Irrigado do Rio Jacarecica I são fatores de interesses para a extração de lucro. Das propriedades visitadas no município de Itabaiana, a maior parte faz uso de irrigação proveniente do Perímetro Irrigado do Rio Jacarecica I, o mesmo ocorre em Lagarto, onde todos os produtores entrevistados disseram que se utilizam de irrigação advinda do Perímetro Irrigado do Rio Piauí. As figuras a seguir (Figuras 01 e 02) apresentam a área de estudo do referido plano de trabalho: 
FIGURA 01 - Perímetro Irrigado Jacarecica I, Itabaiana, Sergipe

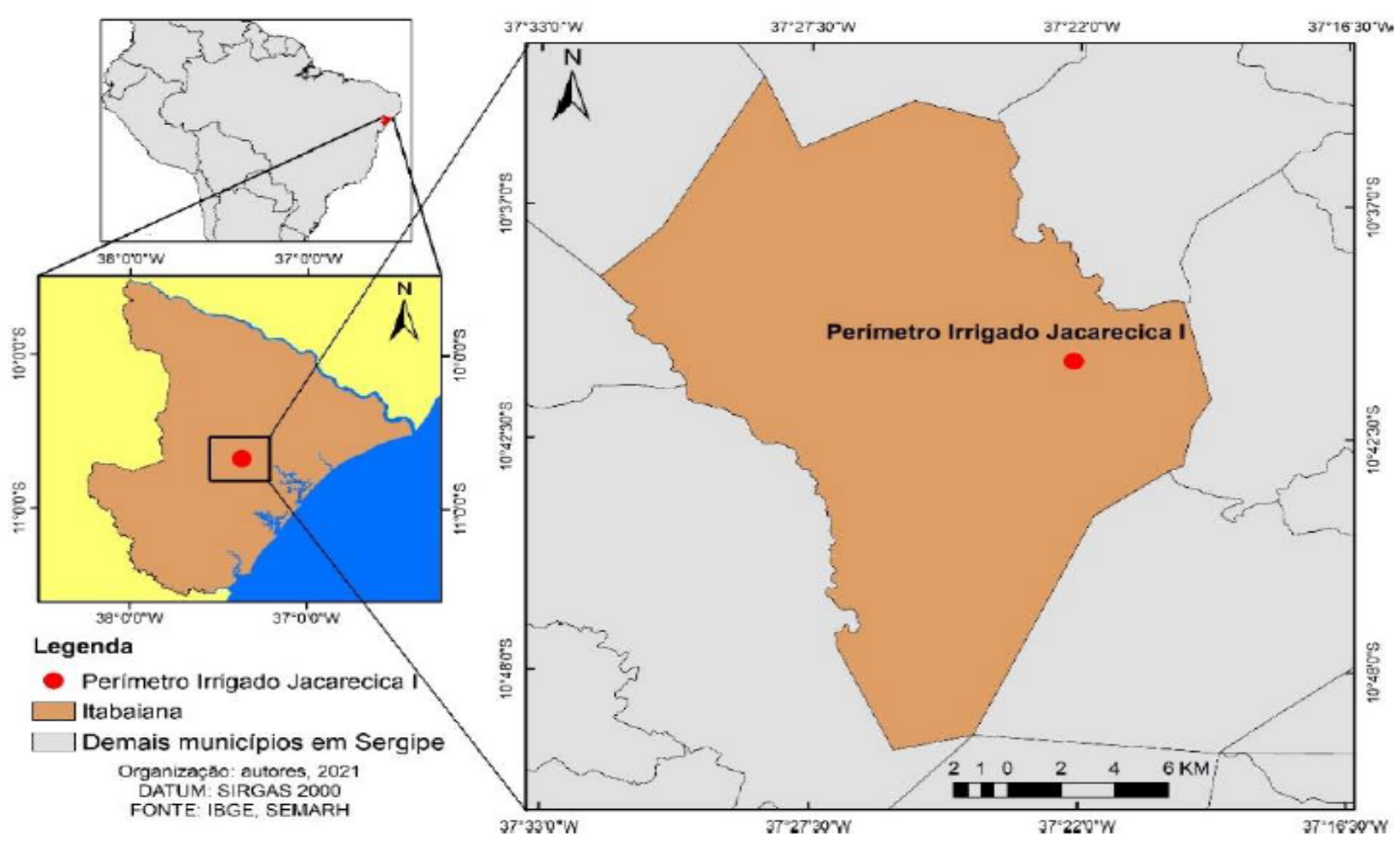

Fonte: autor, 2021

FIGURA 02 - Perímetro Irrigado do Rio Piauí, município de Lagarto, Sergipe

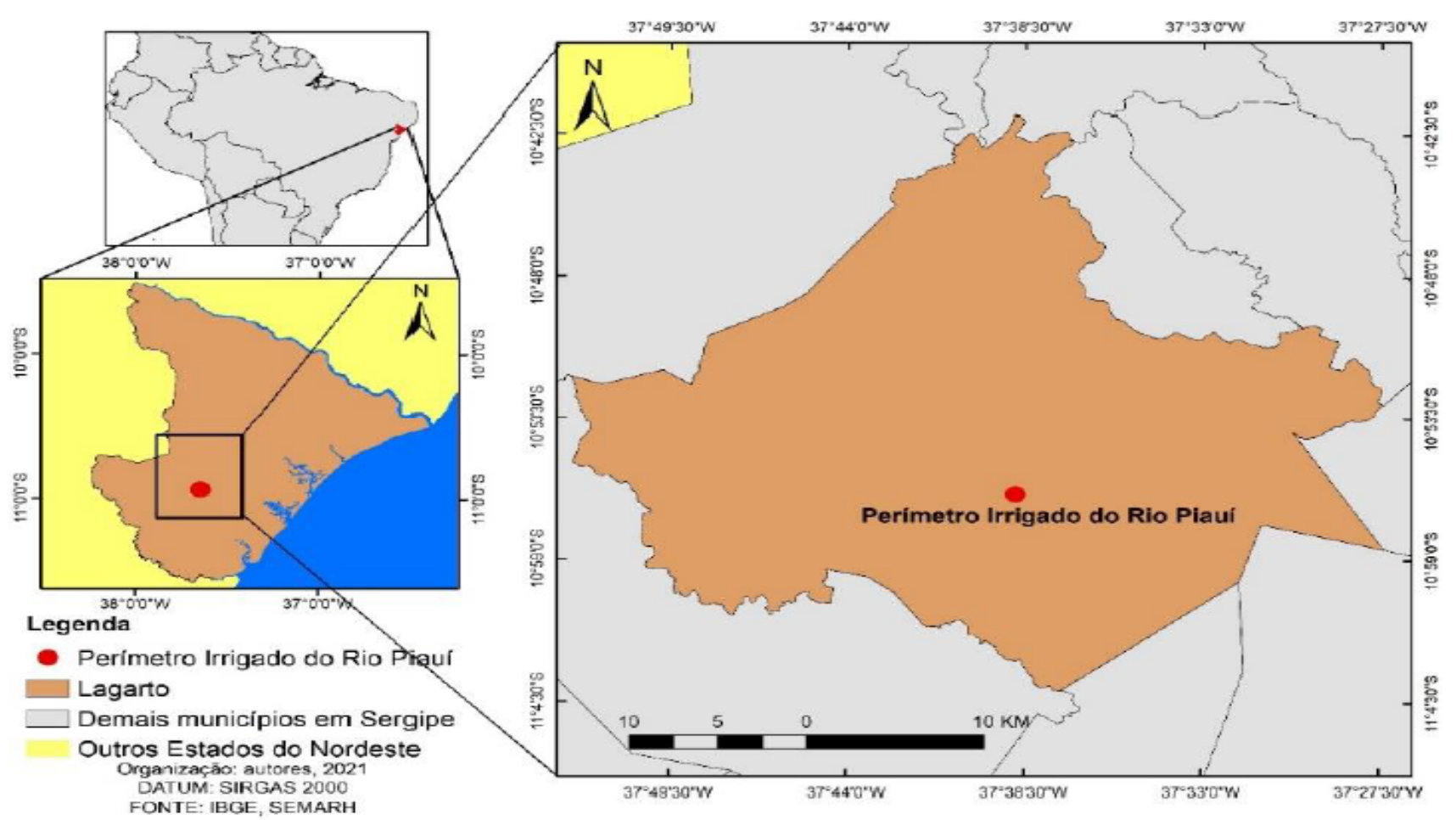

Fonte: autor, 2021 
No quadro da economia sergipana, de acordo com o Censo Agropecuário de 2017 , aumentou-se a produtividade média dos monocultivos de cana de açúcar (primeiro lugar no Nordeste), laranja (segundo lugar no Nordeste) e milho, cujo boom foi impulsionado a partir de 2007, pelos bons preços no mercado em decorrência do aumento da demanda regional por ração animal (IBGE, 2017). Tratam-se de cultivos considerados estratégicos na incorporação de Sergipe no circuito da produção e comercialização do agronegócio brasileiro, sendo seus rebatimentos problemáticos para o conjunto da agricultura camponesa do estado, entre outros aspectos em virtude da redução de área destinada à produção de alimentos e pelo processo de redução do trabalho agrícola (LISBOA, 2007; OLIVEIRA, 2007).

Nesse ínterim, outro cultivo que entra em pauta no agronegócio sergipano é a pimenta (OLIVEIRA, 2011). A produção de pimenta ganha expressão na pauta do agronegócio em função da crescente participação do Grupo Maratá no processo de produção e comercialização de produtos derivados desse vegetal para a produção de molhos. A sua produção foi introduzida em áreas tradicionalmente produtoras de alimentos e se expande pelo Oeste sergipano e municípios alagoanos e baianos.

A partir dos mecanismos de subordinação camponesa de incentivo à produção desse cultivo, em substituição às produções policultoras, alguns rebatimentos socioespaciais são explicitados: a espacialização das produção de pimentas em direção aos Perímetros Irrigados como processo de associação dos interesses do Grupo Maratá ao aparato estatal fornecido a partir de parcerias e concessões; o adoecimento dos trabalhadores em jornadas de trabalho intensificadas e marcadas pelo uso de agrotóxicos para atender às exigências de qualidade do Grupo; e a precarização das relações de trabalho, com a gradativa diminuição da renda e a estrutural desproteção trabalhista no campo. 


\section{DESENVOLVIMENTO}

Foram realizadas visitas técnicas nas áreas de estudo dos municípios correspondentes, quais sejam: os perímetros irrigados do Jacarecica I, em Itabaiana e o perímetro irrigado do Piauí, em Lagarto. Foi possível conhecer a realidade vivenciada pelos sujeitos do campo a partir do cultivo da pimenta em suas pequenas propriedades rurais.

Esta pesquisa esteve fundamentada a partir dos pressupostos do materialismo histórico dialético, como método que possibilita desvelar as contradições engendradas pelo processo de monopolização de territórios produtores de alimentos para a produção de pimentas no Agreste Central Sergipano e no Centro Sul Sergipano, mais precisamente, nos municípios de Lagarto e Itabaiana. Compreendeu-se a necessidade de apreender o objeto em estudo em suas múltiplas determinações, atentando-se para as variadas interrelações e uma compreensão pautada pela totalidade, ou seja, na não dissociação entre o particular-universal.

Nesse sentido, a metodologia teve abordagem quanti-qualitativa, garantindo o levantamento de informações junto a órgãos oficiais, que ajudaram na caracterização da área de estudo, considerando a área ocupada pelos produtores de pimenta, quantidade e valor de produção, número de produtores nos municípios em questão e no estado de Sergipe; e qualitativa, a partir dos trabalhos de campo, com entrevistas semiestruturadas com grupos focais, que contribuíram para a compreensão de como se desenvolve o trabalho agrícola dos produtores da pimenta e trabalhadores temporários, as doenças presentes causadas no desenvolvimento da atividade e os rebatimentos da expansão da área para a produção desse cultivo.

Entre os meses de março e junho de 2021 foram realizados trabalhos de campo com produtores de pimenta residentes em povoados no município de ltabaiana, a citar: Agrovila, Barro Preto e Lagamar, bem como, com uma produtora que trabalha na condição de feirante no Mercado de abastecimento de frutas, verduras e legumes da cidade, residente em outro município, a saber: Moita Bonita, também no Agreste Central Sergipano. Além disso, foram realizadas entre- 
vistas, entre os meses de abril, maio e junho de 2021, via rede social WhatsApp, com representante do Grupo Maratá. Para o município de Lagarto, procedeu-se a revisão de dados encontrados durante trabalho de campo realizado no mês de outubro de 2019, retificados com informações repassadas por 6 entrevistados por telefone e via WhatsApp, além de informações e dados de produção, produtividade e comercialização repassados pelo representante da Maratá, em planilha de Excel.

Como resultados da expansão do cultivo de pimenta em Sergipe tem-se a ocupação de áreas antes destinadas à produção de alimentos subordinadas ao agronegócio da pimenta; uso intensivo de agrotóxicos, sem quaisquer equipamentos de proteção individual (EPIs), com no máximo a utilização de um tecido para cobrir boca e nariz; substituição de trabalho vivo (força física e mental humanas) pelo trabalho morto (máquinas e insumos); apropriação de recursos hídricos para atender ao interesse da produção para a empresa, a citar: uso das águas do Perímetro Irrigado do Rio Jacarecica I e do Perímetro Irrigado do Rio Piauí, em Itabaiana e Lagarto, respectivamente.

Desse modo, entende-se que o agronegócio da pimenta subordina a terra e o trabalho camponês. Os trabalhadores e trabalhadoras são forçados a adaptarem-se à lógica capitalista de produção, em um contexto de jornadas de trabalho extenuantes e insegurança em relação à garantia de uma renda suficiente para a reprodução societal (ALENTEJANO, 2018; MARQUES, 2008). Nesse sentido, os camponeses passam a produzir o que é demandado pela empresa, nesse caso, o Grupo Maratá, deixando de produzir outros tipos de alimentos, a saber: abóbora, feijão, macaxeira e hortaliças.

Para o período correspondente a 2020-2021, o Grupo Maratá espera conseguir com a produção de pimentas do tipo Biquinho, Habanero, Jalapeno e Malagueta um total de 3.916.500,00 quilos de pimenta, numa área de aproximadamente 87,79 hectares de terras. Dividido da seguinte forma: Biquinho - 68.000,00 kg, numa área de 1,4 hec; Habanero - 1.270.000,00 kg, numa área de 39,69 hec; Jalapeno - 1.349.500,00 kg, numa área de 44,98 hec; Malagueta - 1.299.000,00, numa área de 87,79 hec. 
De acordo com seu representante, o Grupo Maratá (T. de Campo realizado via WhatsApp, 31 mai. 2021) informa que os contratos têm validade até setembro do presente ano e, que o acordo estabelecido entre empresa e produtores (133) pode ter o valor alterado para mais ou para menos, mas não abaixo do valor posto no contrato, cujo valor é definido por tipo de pimenta, a saber: malagueta - 8,00 kg; jalapeno - 1,5 kg; habanero - 3,00 kg; biquinho - 6,00 kg. A título de exemplo, a referida fonte conta que no momento - data do trabalho de campo - o quilo da pimenta malagueta estava cotado em doze $(12,00)$ reais.

Os municípios que fazem parte do rol de produção da empresa incluem tanto aqueles que já iniciaram a produção, a partir da década de 2000 , até uma espacialização mais recente, segundo dados da empresa, o município de Lagarto (ver Figura 03) deve fornecer até o fim de setembro, $68.000,00 \mathrm{~kg}$ de pimentas biquinho, $714.000,00$ de pimentas habanero, 455.000,00 de pimentas jalapeno e $435.000,00$ de pimentas malagueta. Em relação a Itabaiana (ver Figura 04) são $20.000,00 \mathrm{~kg}$ de pimentas malagueta.

FIGURA 03 - Localidades no município de Lagarto, Sergipe
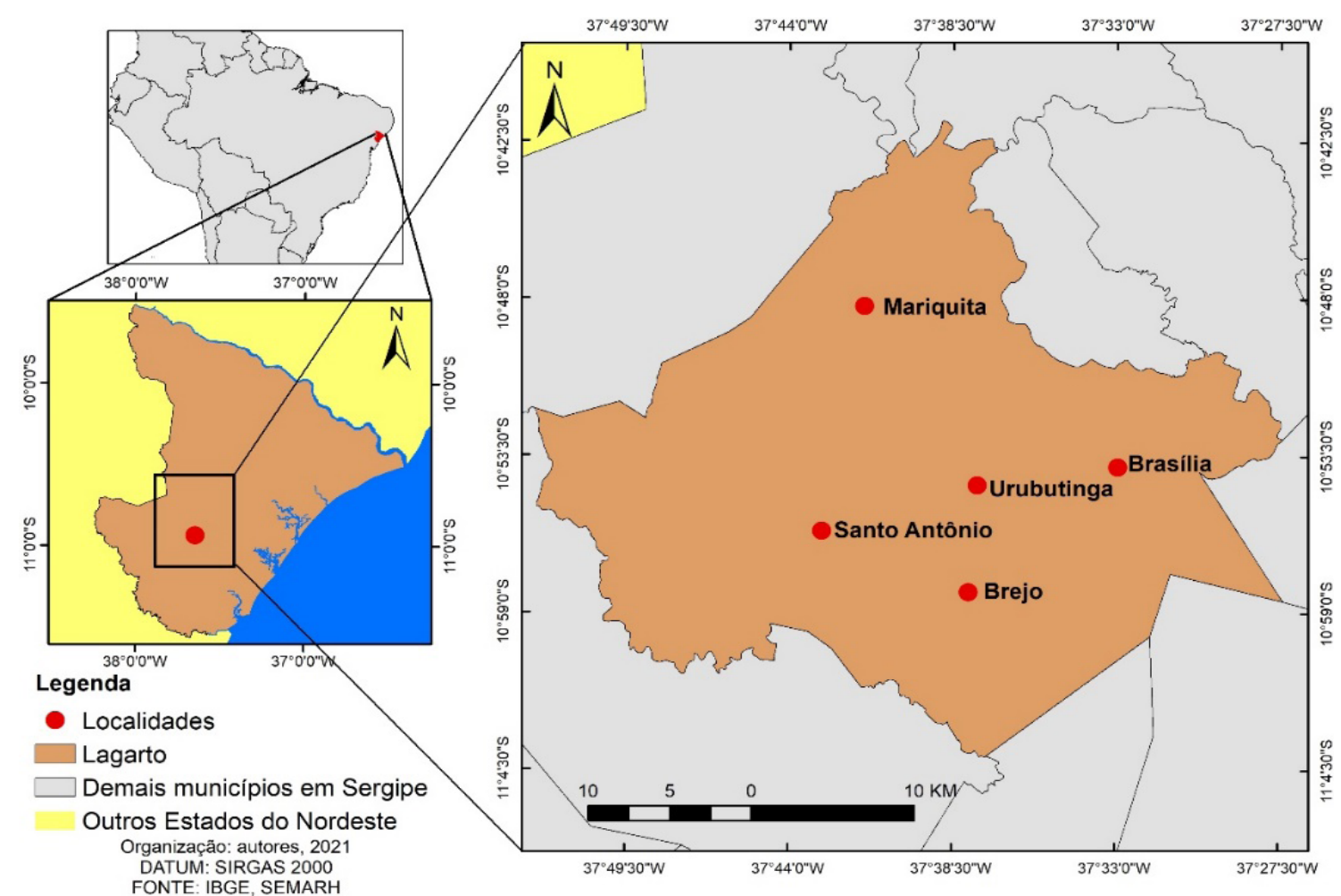

Fonte: autor, 2021 
FIGURA 04 - Localidade da Agrovila, município de Itabaiana, Sergipe
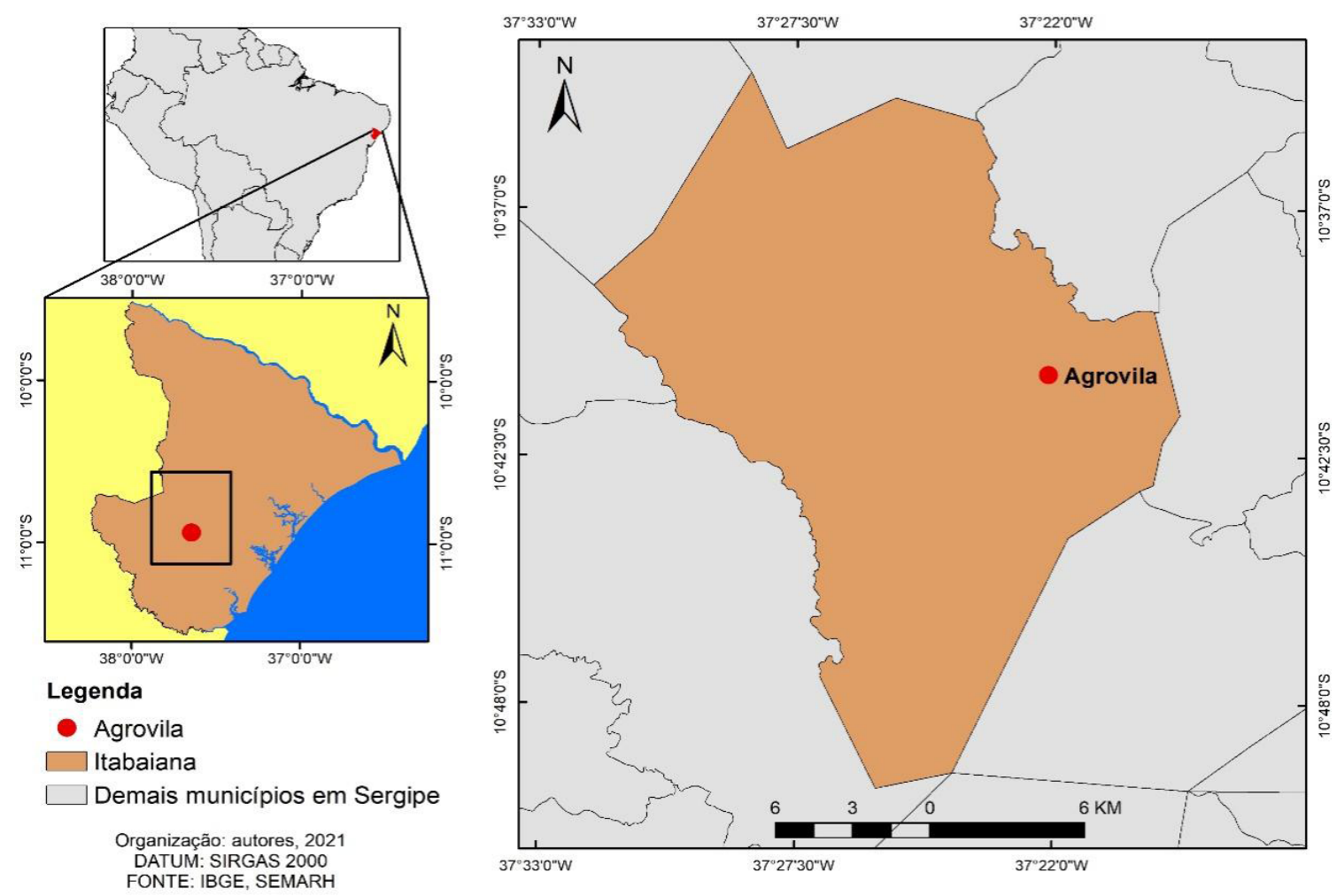

Fonte: autor, 2021

Observou-se que o Grupo Maratá não possuía contratos vigentes com produtores do município de Tobias Barreto, mas que já possuíram há alguns anos. Os trabalhadores são "produtores avulsos", ou seja, camponeses que não têm contrato com a empresa, mas que fornecem suas produções em períodos específicos. Baseado nessa informação, constata-se que é crescente essa parcela, tendo em vista que muitos produtores não possuem contratos assinados com o Grupo Maratá, sendo o caso da entrevistada (M. C. dos S., 50 anos, T. de Campo, Feira de Itabaiana - SE, 24 mar. 2021), a mesma nos informa que entrega mensalmente na Feira de Itabaiana de 3 a $4 \mathrm{~kg}$ da pimenta malagueta a um funcionário da própria empresa, recebendo um valor em torno de 40,00 reais pelo produto (ver Figura 05). 
FIGURA 05 - Variedade de pimentas comercializadas na Feira semanal de Itabaiana, 2021

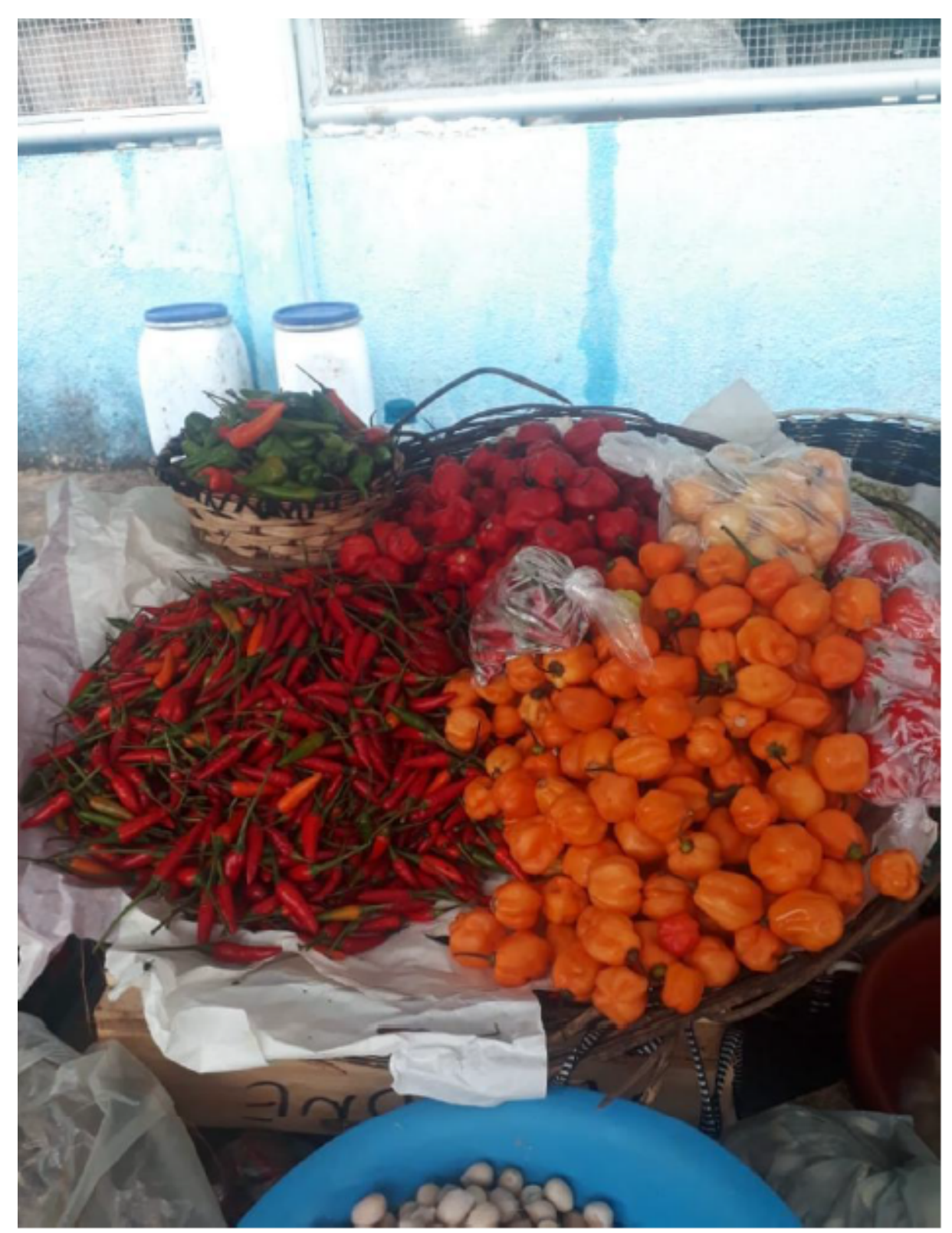

Fonte: autor, 2021

Como forma de controlar todo o percurso da produção, o Grupo Maratá realiza acompanhamento nas propriedades, a fim de averiguar se o que foi solicitado pela empresa está realmente sendo cumprido, caso contrário, os produtores podem ter suas produções dispensadas em caso de falhas nesse processo. $O$ acompanhamento consiste em duas visitas técnicas feitas por um engenheiro agrônomo, a primeira para saber se o camponês realizou a produção e a segunda, geralmente entre 60 a 90 dias, com o objetivo de fornecer uma projeção de colheita para a empresa. 
Trata-se de um quadro que expõe a subordinação dos espaços de produção camponesa, tendo em vista que as áreas agricultáveis destinadas ao plantio de pimenta, perdem sua autonomia, ficando seu controle sob as diretrizes do sistema de produção requerido pelo grupo empresarial.

Percebe-se que a maior parte da produção é passada para atravessadores que tem como destino o mercado baiano, na cidade de Salvador. A senhora M. J. (45 anos, T. de Campo, Pov. Barro Preto, 04 mar. 2021) relata que trabalha no campo desde a infância, fazendo o que gosta, mas que os tempos estão mudado. A entrevistada planta e colhe as pimentas durante todo o ano na propriedade da sua irmã, recebendo uma diária que varia entre 25/30 reais a depender da quantidade colhida naquele dia, geralmente é pago 2,00 a 3,00 por quilo, colhendo em torno de 12 a $15 \mathrm{~kg}$ diariamente. A mesma destaca que eles fazem uso de agrotóxicos na produção. Quando questionada sobre o uso EPIs, disse que não o fazia. Por fim, M. J. conta que as águas do Perímetro Irrigado do Rio Jacarecica I são usadas na irrigação da produção de pimenta.

O caso citado é semelhante a muitos outros encontrados durante a realização de pesquisa, por exemplo, o camponês E. dos S. M. (41 anos, T. de Campo, Pov. Zanguê, 04 mar. 2021) ressalta que cultiva em sua propriedade batata doce, amendoim e pimentas. O entrevistado exemplifica que o processo se inicia com o trato da terra, sendo utilizado um trator para arar, logo depois é feito plantio, durante o período de crescimento da planta, é feito uso de vários tipos de agrotóxicos, a saber: Vertimec, Gramocil, Cypitrin e um popularmente denominado de "mineirinho" - usado nas folhas da planta, além de irrigação do Perímetro Irrigado do Rio Piauí. Todo o processo de colheita emprega em torno de 5 a 6 pessoas, que realizam uma nova colheita a cada 15 dias. A produção é passada para um atravessador que entrega uma parte para o Grupo Maratá, sendo a outra parte mandada para Salvador.

Nos últimos anos, a diminuição nos preços médios da produção é responsável por consecutivos prejuízos para a renda dos trabalhadores. Ademais, ao cansaço somam-se adoecimentos devido a exposição aos agrotóxicos, em que 
A QUESTÃO AGRÁRIA NO BRASIL: CAMPESINATO, AGRICULTURA FAMILIAR E AGRONEGÓCIO

um dos entrevistados ter ido para o hospital, com "sensação do rosto queimando e tontura".

Os produtores de pimenta têm reclamado dos baixos preços pagos na aquisição do produto; para o produtor M. dos S. (51 anos, T. de Campo. Pov. Agrovila, 04 mar. 2021) são poucos os ganhos com a produção de pimenta malagueta, suficiente apenas para complementar a renda da família. Para além da pimenta, o senhor M. dos S., cultiva maxixe e quiabo. O mesmo diz que faz uso de irrigação proveniente do Perímetro Irrigado do Rio Jacarecica I, bem como, de agrotóxicos na produção de pimentas. Por semana, é colhido em torno de $150 \mathrm{~kg}$, sendo que o valor do $\mathrm{kg}$ é de 3,00 reais. A produção final é entregue para dois atravessadores que escoam o produto para o mercado baiano, na cidade de Salvador. Mesmo com todas as dificuldades expostas pelo produtor, quando questionado sobre o sentido da terra para ele e para a família, a resposta é enfática, "Eu me realizo enquanto camponês. Consigo sobreviver com o trabalho no campo, aqui nós temos muita água para plantar" (M. dos S.; 51 anos, T. de Campo. Pov. Agrovila, 04 mar. 2021).

A jovem N. N. S. (24 anos, T. de Campo. Pov. Lagamar, 21 mai. 2021) explana que abandonou os estudos na sexta série, atual sétimo ano, e que se dedica às atividades agrícolas. No seu sítio, são produzidos: batata-doce, quiabo, feijão de corda e pimenta malagueta. Sobre a produção de pimenta, a entrevistada conta que é um produto rápido e que, por isso, decidiu realizar o plantio. Questionada sobre o processo, a mesma relata que emprega de uma a duas pessoas no período de colheita, e faz uso de irrigação proveniente de poço "artesiano", além de usar agrotóxicos nas fases de plantio e de colheita da pimenta, ressaltando que o descarte das embalagens é feito através do serviço de coleta de lixo do próprio município, ou seja, os funcionários dessa atividade são expostos aos vasilhames que contêm restos de produtos químicos de alta periculosidade. A produtora explica que já teve alguns casos de adoecimento de trabalhadores por causa da atividade da pimenta, e que nesses casos, o médico recomendou o afastamento imediato dessa prática laboral, devido a recorrência de "alergia no corpo". 
A QUESTÃO AGRARIA NO BRASIL: CAMPESINATO, AGRICULTURA FAMILIAR E AGRONEGÓCIO

O senhor D. P. dos S. (35 anos, T. de Campo. Pov. Agrovila, 04 mar. 2021) relata que na sua propriedade são cultivados: batata doce, o quiabo, amendoim e pimenta malagueta. Sobre a pimenta, a colheita ocorre durante todo o ano, com uma produção em torno de 300 a $400 \mathrm{~kg}$ por colheita, que é transferida para três atravessadores, que exportam para o mercado de Salvador. O entrevistado não faz uso de agrotóxicos, explanando que tem conhecimento sobre a nocividade desses produtos, tanto para os sujeitos do campo quanto para os que estão na cidade, enfatizando que prefere aderir a práticas alternativas. Para isso, o produtor participou de um curso oferecido pela Companhia de Desenvolvimento de Recursos Hídricos e de Irrigação de Sergipe (COHIDRO), no ano de 2020, tendo acesso a como realizar plantios sem a necessidade de fazer usos de venenos. $\mathrm{Na}$ sua terra, o mato funciona como adubo, bem como, os instrumentos para trabalhar a terra, a saber: enxada e cavador, o esterco de animais também utilizado para fornecer fontes de minerais para as plantas em desenvolvimento.

A permanência camponesa é desvelada na fala do camponês D. P. dos S. "A terra é vida. A terra produz para a gente, fornece alimentos que garantem a nossa sobrevivência, mesmo com todas as dificuldades, eu não penso em deixar a vida no campo" (D. P. dos S. 35 anos, T. de Campo. Pov. Agrovila, 04 mar. 2021).

Diante do exposto, portanto, nota-se que o camponês é subordinado ao ser forçado a mudar as suas práticas agrícolas em detrimento de demandas estabelecidas no bojo das relações capitalistas de produção. Nesse sentido, terras destinadas à produção de alimentos, com o objetivo de atender tanto o consumo dos trabalhadores rurais, quanto a comercialização de seu excedente como parte da possibilidade de perpetuar sua permanência no campo, são condicionadas à produção em larga escala de uma única produção, a pimenta, cuja lógica capitalista está intrínseca ao processo de valorização de valor.

Para Campos (2011, p. 111): “O agronegócio se viabiliza por meio da apropriação de espaços nos estados para garantir recursos e condições políticas e jurídicas favoráveis às suas atividades". Com o apoio do poder estatal, financei- 
ro e midiático, o agronegócio da pimenta no estado de Sergipe aparece como uma atividade que promove desenvolvimento e qualidade de vida digna para os agricultores que se inserem no circuito de produção. Através do discurso de um mercado certo para escoar a mercadoria, os camponeses passam a produzir o que é solicitado pelo mercado, deixando de cultivar feijão, abóbora, inhame, macaxeira, quiabo, maxixe, batata doce, hortaliças e etc., em detrimento de um único produto - a pimenta - que serve de matéria base para a produção de moIhos industrializados.

Todavia, com poucos anos de mudança no processo de cultivo, os trabalhadores compreendem que o processo de subordinação destituiu a relativa autonomia sobre a própria produção, diante da satisfação do lucro (FABRINI; PAULINO, 2008; PAULINO, 2008). As precárias condições de trabalho espelham a precariedade da vida, inseridos como produtores "avulsos", cujo fardo expressa-se nas reclamações, que apontam os baixos preços pagos pela Maratá; pragas recorrentes - intensificando o uso de agrotóxicos; adoecimento no desenvolvimento da atividade laboral; empobrecimento da terra devido ao plantio de apenas um cultivo, não havendo uma rotatividade de culturas agrícolas. Tem-se, pois, a transformação de lugares de sociabilidade camponesa em territórios da subordinação capitalista. Enquanto nos lugares existe a manutenção de um modo de vida intrínseco à produção de alimentos e, dessa forma, a geração de renda para a unidade familiar camponesa e a comunidade - povoado -; os territórios constituídos pela subordinação são resultantes da espacialização da produção capitalista, ou seja, do mundo da mercadoria, expresso pelo atendimento aos interesses do capital no campo:

Um determinado espaço torna-se território do agronegócio quando nele os seus segmentos têm o domínio, ou seja, condicionam os usos do espaço; utilizam do poder econômico para adequar as decisões políticas a seus interesses; controlam o mercado de trabalho estabelecendo as condições e as remunerações. (CAMPOS, 2011, p. 113).

Com a espacialização do agronegócio da pimenta em lugares de permanência camponesa, os sujeitos também passam a fazer parte de uma cadeia pro- 
dutiva ampla, para além das mudas e da própria força de trabalho, grande parte dos produtores são levados a adquirirem produtos químicos - agrotóxicos - para gerar uma mercadoria de melhor qualidade, haja vista que os compradores observam a textura, cor e tamanho das pimentas, sendo descartadas todas aquelas que não se enquadram como "um produto bonito". Das seis (6) propriedades visitadas entre os meses de março a maio de 2021 no município de Itabaiana, em Sergipe, cinco (5) faziam uso de insumos químicos durante o período de plantio, crescimento e colheita das pimentas. Em Lagarto - SE, nas visitas a três (3) propriedades no mês de outubro de 2019 , todos disseram que usam algum tipo de agrotóxico. A justificativa é a mesma para os dois grupos, caso as pimentas não estejam apresentáveis, os compradores não aceitam a produção. Sobre essa questão, o representante do Grupo Maratá informa que a empresa pede para que os produtores não façam uso desses produtos, sendo o ideal desenvolverem medidas alternativas. Segundo representante do Grupo Maratá:

A empresa não faz a orientação para produtos químicos, geralmente a gente indica a utilização de produtos alternativos. Quando existe a necessidade de utilizar um produto químico, eu sempre indico um técnico da região, mas a gente não se compromete com a indicação, porque tem que ter o receituário agronômico, toda essa parte sistemática (Representante XX do Grupo Maratá, T. de Campo realizado via WhatsApp, 16 jun. 2021).

Todavia, os produtores L.; D.; e G. (T. de Campo, 24 out. 2019, Lagarto $\mathrm{SE})$ que têm propriedades em povoados localizados no município de Lagarto, disseram que já tiveram ou conhecem alguém que teve suas produções consideradas incompatíveis pelo Grupo Maratá, como o uso dos agrotóxicos um mecanismo de conseguir um produto em quantidade e qualidade suficientes para o conglomerado.

Nesse sentido, o Grupo se exime de possíveis problemas que possam afetar a saúde dos trabalhadores diante do uso exacerbado de venenos agrícolas, tendo em vista que, para além do risco de utilizarem esses produtos com todo o aparato de segurança, dos onze (11) produtores entrevistados, tanto no município de Itabaiana quanto no município de Lagarto, dez (10) disseram que utilizam 
os produtos químicos sem quaisquer uso de EPIs, fazendo uso apenas de camisas de mangas longas para proteger braço e antebraço, e de um pedaço de tecido para cobrir boca e nariz, deixando expostos os olhos.

No município de Itabaiana, três (3) produtores relataram que já tiveram ou conhecem alguém com problemas de saúde decorrentes do manejo com a pimenta, os sintomas mais recorrentes são: dores na lombar - devido a posição que os trabalhadores ficam durante a colheita (ver Figura 06), alergia nos olhos e pele, sensação de ardência no rosto e tonteira.

FIGURA 06 - Trabalhadores na colheita de pimenta, Lagarto, Sergipe, 2021

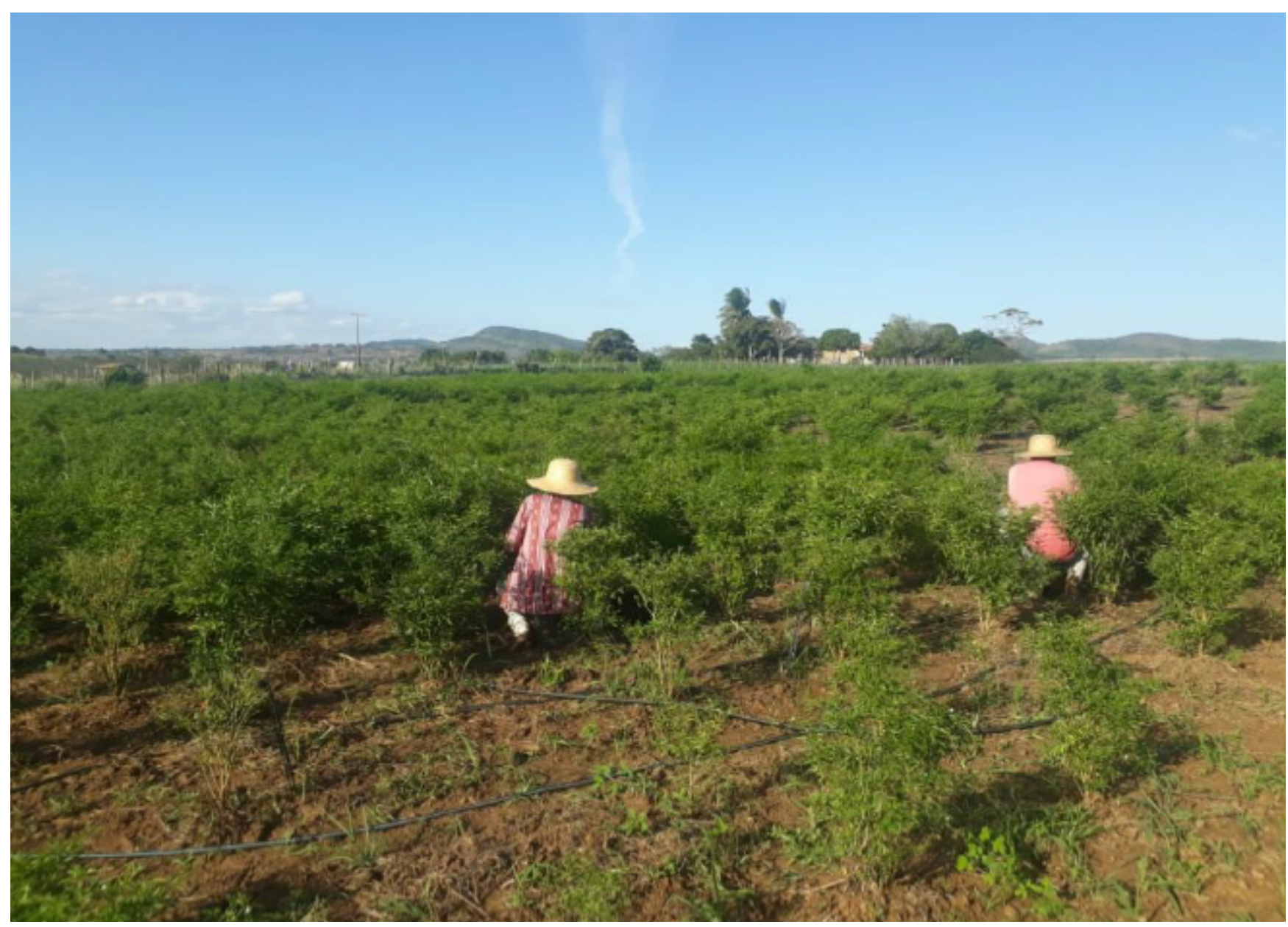

Fonte: autor (2021)

Para além dos casos de doenças decorrentes do manejo de agrotóxicos, os produtores têm perdido espaço no campo com a inserção de novas tecnologias, responsáveis tanto pela tecnificação agrícola, quanto pela disseminação 
do desemprego estrutural no campo. Com a utilização em massa de insumos químicos; tratores - fornecidos a partir do financiamento, que envolve o aparato estatal, bancos e linhas de crédito; e outras técnicas (trabalho morto/capital constante/, os trabalhadores rurais (trabalho vivo/capital variável) são forçados a migrarem para as cidades, passando a ocupar as áreas periféricas e subempregos. Dessa forma, dos seis (6) produtores entrevistados no município de Itabaiana, todos disseram que a vida no campo é cada vez mais difícil, por conta da ausência de trabalho, mas contraditoriamente, afirmam que não existe força de trabalho suficiente para as funções. A partir dos relatos, a realidade se revela: o trabalho camponês é cada vez mais abarcado pela introdução de novas técnicas de aumento da produtividade, em um contexto de acirramento da competição intercapitalista e da queda geral nas taxas médias de lucro.

\section{CONCLUSÕES}

A partir dos resultados da pesquisa, diante dos objetivos propostos, chegam-se às seguintes conclusões: 1. A subordinação camponesa acompanha um processo atual de destituição do sentido de soberania alimentar de comunidades de camponeses em Sergipe, a partir das realidades dos povoados e dos trabalhadores pesquisados; 2. O monopólio agroindustrial do Grupo Maratá está historicamente vinculado à exploração da terra e do trabalho em Sergipe, seja com a expropriação de terra, ou com as estratégias de compra de uma produção determinada a partir de seus interesses de lucro; 3. Dissemina-se, a partir da modernização da produção, os discursos de inserção no mercado capitalista, pautados na adequação tanto das técnicas, quanto da própria força de trabalho - agrotóxicos, maquinário, tempo de trabalho, etc.; 4. O cotidiano dos trabalhadores e trabalhadoras da pimenta é marcado pelo adoecimento físico e mental, com as jornadas extenuantes de labor e a contaminação pela utilização de venenos agrícolas e o manuseio com as pimentas; bem como, pela instabilidade laboral, sem proteção trabalhista ou garantia de uma renda estável. 
Além disso, esse contexto de intensificação do fardo laboral está intrínseco à mobilidade campo-cidade, em grande parcela dos jovens camponeses, que adentram uma situação marcada pela informalidade. Com uma ideologia que o campo é arcaico, devendo modernizar-se, os camponeses são subordinados a um contexto de destituição da autonomia vinculada à produção de comida para a mesa dos brasileiros e brasileiras. Os trabalhadores com maior tempo de vida ressaltam a seguridade repassada pela terra, ou seja, explicitam a importância do plantar para comer. Portanto, reafirmam nas palavras e no modo de vida campesino, a esperança de uma permanência que possa se constituir em possibilidade de luta contra o capital.

\section{REFERENCIAS}

ALENTEJANO, Paulo. A política agrária no Governo Temer: a pá de cal na agonizante reforma agrária brasileira? Revista Okara: Geografia em debate, v. 12, n. 2, p. 308-325, 2018. ISBN: 1982-3878.

CAMPOS, C. S. S. A face feminina da pobreza em meio a riqueza do agronegócio: trabalho e pobreza das mulheres em territórios do agronegócio no Brasil. 1. ed. Buenos Aires: CLACSO, 2011.

DELGADO, Guilherme Costa. Heranças e perspectivas de desenvolvimento da agricultura brasileira. 2016.

COHIDRO. Perímetro Irrigado Piauí. Disponível em: https://cohidro.se.gov. br/?page_id=21. Acesso em: 22 de mai. de 2020.

MARQUES, M. I. M. A atualidade do uso do conceito camponês. Revista Nera. Presidente Prudente, $\mathrm{n}^{\circ}$ 12, p. 57-68, jan.-jun. 2008.

FABRINI. J. E. PAULINO. E. T. (Orgs.). Campesinato e territórios em disputa. $1^{\circ}$ ed. Editora Expressão Popular: São Paulo, 2008.

INSTITUTO BRASILEIRO DE GEOGRAFIA E ESTATÍSTICA (IBGE). Censo agropecuário 2017 - resultados preliminares. Rio de Janeiro: IBGE, 2017. 
LISBOA, Josefa. A trajetória do discurso do desenvolvimento para o Nordeste: políticas públicas na (dis)simulação da esperança. Tese de Doutorado. Programa de Pós-Graduação em Geografia/UFS, 2007

OLIVEIRA, A. U. de. A mundialização da agricultura brasileira. São Paulo: lãnde Editorial, 2016.

OLIVEIRA, E. R. S. dos. S. A dinâmica do Agronegócio em Lagarto/SE: limites, impasses e alcances. 2011. 145f. Dissertação de Mestrado - Universidade Federal de Sergipe, São Cristóvão, 2011.

OLIVEIRA, V. D. de. As tecnologias e suas interfaces no campo como estratégia de controle do capital. 2007. 220f. Dissertação de Mestrado - Universidade Federal de Sergipe, São Cristóvão - SE, novembro de 2007.

PAULINO. E. T. Território e campesinato: da teoria à práxis. Terra Plural, Ponta Grossa, 2 (1): 199-211, jul./dez., 2008. Acesso em: 04 nov. 2019.

THOMAZ JUNIOR, A. Degradação sistêmica do trabalho no agrohidronegócio. Revista Mercator. Fortaleza, v. 16, p. 1-20, 2017. ISBN: 1984-2201

, A. O agrohidronegócio no centro das disputas territoriais e de classe social no Brasil do século XXI. 2009.

tóxicos. 2017.

A. Trabalho rural, degradação ambiental e contaminação por agro- 


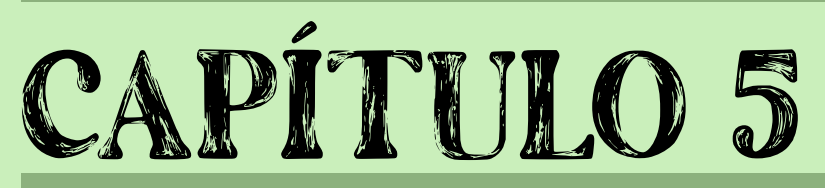

\section{FORMAÇÃO DE DOCENTES DA EDUCAÇÃO DO CAMPO:} CONSIDERAÇÕES SOBRE AS EXPERIÊNCIAS DO CEGEO/PRONERA E DA LEDUC/PROCAMPO'

Rodrigo Simão Camacho

$1 \quad$ Artigo teve uma primeira versão publicada nos ANAIS do Simpósio Internacional de Geografia Agrária - (SINGA), Recife, PE, nov. 2019. Disponível em: https://singa19.files.wordpress.com/2020/10/versao-final-anais-ix-simposio-internacional-de-geografia-agraria-e-x-simposio-nacional-de-geografia-agraria-2019.pdf. 


\section{INTRODUÇÃO}

O objetivo deste artigo é o de analisar duas experiências de formação de educadores por meio de políticas públicas emancipatórias, uma pelo Programa Nacional de Educação na Reforma Agrária (PRONERA) e outro pelo Programa de Apoio à Formação Superior em Licenciatura em Educação do Campo (PROCAMPO).

As políticas públicas fazem parte da construção de uma concepção de igualdade jurídico-política presente em nossa sociedade atual. Elas significam a materialização dos direitos contidos no artigo $6^{\circ}$ da Constituição Federal brasileira de 1988. Dentre estes direitos constitucionais está a educação (MOLINA, 2012).

É de fundamental importância que as universidades possam formar educadores-professores preparados para compreender a realidade do campo. Temos a necessidade urgente de pensar os direitos dos sujeitos concretos com suas especificidades: classe, culturais, identitárias, territoriais, gênero, étnicas ou raciais. Isto significa pensar em políticas focadas nessas especificidades. O caso da formação de professores-educadores das escolas do campo é uma formação específica que se faz necessária para garantia dos direitos nas especificidades territoriais de seus povos.

A história da Educação do Campo está diretamente relacionada com a conquista de políticas públicas. A primeira grande conquista da Educação do Campo foi o PRONERA. O Programa nasceu em 1998 da luta das representações dos movimentos sociais e sindicais do campo. Sob influência teórica-política-ideológica do PRONERA se origina o Programa de Apoio à Formação Superior em Licenciatura em Educação do Campo (PROCAMPO).

O Curso Especial de Graduação em Geografia é um curso construído junto com os militantes dos movimentos socioterritoriais camponeses, estabelecendo-se uma relação entre a Universidade, os Movimentos Sociais e o Estado por meio do PRONERA. Neste curso se formaram 46 camponeses-assentados licenciados e bacharéis em geografia. 
No Curso de Licenciatura em Educação do Campo (LEDUC) na Universidade Federal da Grande Dourados (UFGD), o grau acadêmico conferido é de Licenciado em Educação do Campo com Habilitação em Ciências da Natureza ou Licenciado em Educação do Campo com Habilitação em Ciências Humanas.

Partimos do princípio de que um dos objetivos do curso é o de compreender as diferentes formas de reprodução dos sujeitos do campo e a multidimensionalidade de seus territórios (política, econômica, cultural, ambiental), seus diálogos e conflitualidades, para, a partir dessa reflexão, pensar os projetos político-pedagógicos, os conteúdos programáticos e as metodologias de ensino-aprendizagem nas escolas do campo.

As experiências de Educação do Campo que estão sendo desenvolvidas a partir do PRONERA e PROCAMPO permitem que visualizemos o protagonismo da sociedade civil organizada, por meio dos movimentos socioterritoriais camponeses, na elaboração de uma política pública que está construindo uma nova visão sobre o Estado, o Campo/Campesinato, a Educação, a Universidade e a Democracia.

Possibilitam a formação de um intelectual orgânico com instrumentos suficientes para contribuir para o desenvolvimento socioterritorial junto a sua comunidade por meio da elaboração de políticas públicas, no planejamento socioterritorial do assentamento, na prática docente em sala de aula, na militância dos movimentos socioterritoriais.

Para a construção desse artigo utilizamos como instrumento metodológico a revisão bibliográfica em diálogo com a análise do documento "Manual de Operações do PRONERA" de 2011, do Projeto Político-Pedagógico (PPP) do Curso Especial de Graduação em Geografia (CEGeo) da UNESP e o Projeto Pedagógico Curricular (PPC) do Curso de Licenciatura em Educação do Campo (LEDUC) da UFGD, a observação participante e as entrevistas com educandos e professores dos cursos. 


\section{DESENVOLVIMENTO}

\section{A FORMAÇÃO DE EDUCADORES DO CAMPO}

O marco inicial na história da Educação do Campo é quando, em 1997, o Movimento dos Trabalhadores Rurais Sem Terra (MST) realizou, em conjunto com a Universidade de Brasília (UNB) e o Fundo das Nações Unidas para a Infância (UNICEF), o I Encontro Nacional de Educadores de Reforma Agrária (I ENERA). O tema central era "Com escola, terra e dignidade". O segundo marco histórico da Educação do Campo foi Conferência Nacional Por uma Educação Básica do Campo. Foram os parceiros: a Conferência Nacional dos Bispos do Brasil (CNBB), a Universidade de Brasília (UNB), a Organização das Nações Unidas para a Educação, a Ciência e a Cultura (UNESCO Brasil), e o Fundo das Nações Unidas para a Infância (UNICEF), com apoio do Grupo de Trabalho e Apoio à Reforma Agrária (GTRA). Foram mil participantes reunidos em Luziânia-GO, de 27 a 31 de julho de 1998. Neste encontro, formaram a Articulação Nacional Por Uma Educação Básica do Campo (CALDART, 2004; CAMACHO, 2014).

No caso específico da formação de educadores-professores na Educação do Campo, este processo é pensado tendo como pressuposto a perspectiva de educação freireana (FREIRE, 1983), o professor-educador deve ter consciência de seu papel de romper com a dominação do passado e contribuir para construir um presente livre da ideologia dominante que mantém a opressão e a desigualdade social e econômica. Todavia, partindo do princípio que a educação não muda o mundo, a educação muda às pessoas que, por sua vez, criam/recriam o mundo, a formação de educadores para a mudança ou para a manutenção é um território em disputa (CAMACHO, 2014).

Para a consolidação de uma formação acadêmica articulada com as lutas sociais, é necessário que disputemos com a ideologia dominante o significado do campo. A produção teórico-acadêmica numa perspectiva emancipatória pode contribuir com a formação de intelectuais das classes subalternas que vão fazer esta disputa hegemônica (SÁ; MOLINA, 2010; CAMACHO, 2014). 
Para engendrar este debate contra-hegemônico acerca do campo é necessário que tenhamos professores-educadores-camponeses formados pela lógica da Educação do Campo fazendo a disputa com a ideologia dominante. Todavia, as condições históricas ainda são precárias para a consolidação deste objetivo, as escolas do campo hoje são constituídas por profissionais com falta de conhecimento e de engajamento com os princípios da Educação do Campo, que desconhecem a realidade de onde estão lecionando (BATISTA, 2007; CAMACHO, 2014).

É necessário um profissional capaz de conhecer a multidimensionalidade da realidade em conflito no campo, que compreenda a infância e a juventude camponesa, que ele irá educar e o próprio destino e permanência das escolas do campo, tendo em vista que de acordo com dados do próprio INEP, mais de 32 mil escolas rurais foram fechadas nos últimos dez anos, passando-se de 102 mil escolas, em 2002, para 70 mil em 2013 (MOLINA; ANTUNES-ROCHA, 2014).

Temos a necessidade urgente de pensar os direitos dos sujeitos concretos com suas especificidades: culturais, identitárias, territoriais, étnicas ou raciais. Isto significa pensar em políticas focadas nessas especificidades. Os princípios, normas e políticas generalistas não têm garantido o direito às diferenças de gênero, classe, raça, etnia, território etc. O protótipo de cidadão universal ignora as alteridades, as diferenças de gênero, classe, raça, etnia e território. Com a intenção de formar um profissional único de educação, num sistema único, com currículos e materiais únicos, orientados por políticas únicas, os direitos às diferenças continuam não garantidos. Por isso, não temos, historicamente, uma tradição de formulação de políticas públicas, bem como de teorias e práticas, que tenha a formação de professores-educadores do campo como preocupação central. O caso da formação de professores-educadores das escolas do campo é uma formação específica que se faz necessária para garantia dos direitos na especificidade de seus povos (ARROYO, 2007). 
A QUESTÃO AGRARIA NO BRASIL: CAMPESINATO, AGRICULTURA FAMILIAR E AGRONEGÓCIO

É de fundamental importância que as universidades possam formar educadores-professores preparados para compreender a realidade do campo, por isso, estes educadores-professores devem ser oriundos dessa realidade. Camponeses-militantes que se tornam camponeses-militantes-estudantes na universidade e, em seguida, camponeses-militantes-professores nas escolas dos assentamentos (CAMACHO, 2014).

Existem três vantagens estratégicas para a formação de professores oriundos dos próprios assentamentos. A primeira é a elevação do grau de instrução dessa população. A segunda é o envolvimento desses profissionais com a comunidade. E a terceira é a melhoria de qualidade de ensino nas escolas do campo tendo em vista a utilização de conteúdos e metodologias específicas para realidade dos assentados (ANDRADE; DI PIERRO, 2004; CAMACHO, 2014).

A proposta de formação de professores-educadores assentados não se trata apenas de uma solução pragmática para a escassez de educadores habilitados nos assentamentos, mas também de uma aposta na hipótese de que o processo de ensino-aprendizagem será favorecido pelo fato de os educadores compartilharem com os educandos a mesma linguagem, cultura e histórica de luta, o que Ihes possibilita assumir o papel de agentes dinamizadores da vida cultural das comunidades. (ANDRADE; DI PIERRO, 2004, p. 28).

Os movimentos socioterritoriais camponeses propõem que nos cursos de formação de educadoras e educadores do campo estejam incluídos conhecimentos que dizem respeito às especificidades dos camponeses. A terra-território deve ser a temática central, pois lhe é inerente às questões relativas ao modo de vida, a cultura, a identidade etc. Temáticas como: o conflito e as disputas territoriais entre o campesinato e o agronegócio, a concentração fundiária, a reforma agrária, a territorialização-desterritorialização-reterritorialização dos povos do campo, os movimentos socioterritoriais do campo etc. devem fazer parte do currículo da formação específica de educadoras e educadores do campo (ARROYO, 2007; CAMACHO, 2014). 
A QUESTÃO AGRÁRIA NO BRASIL: CAMPESINATO, AGRICULTURA FAMILIAR E AGRONEGÓCIO

\section{AS POLÍTICAS PÚBLICAS DE FORMAÇÃO DE EDUCADORES}

Para pensarmos a formação de educadores do campo, temos que refletir acerca da conquista e ampliação das políticas públicas. A história da Educação do Campo está diretamente relacionada com a conquista de políticas públicas. A primeira grande conquista da Educação do Campo foi o PRONERA. Mas, o tema de políticas públicas adquire caráter central a partir da II Conferência Nacional de Educação Básica do Campo, quando se consolida com a expressão Educação do Campo: direito nosso, dever do Estado (MOLINA, 2012).

As políticas públicas fazem parte de uma construção de concepção da igualdade jurídico-política que está presente em nossa sociedade atual. Elas significam a materialização dos direitos contidos no artigo $6^{\circ}$ da Constituição Federal brasileira de 1988. Dentre estes direitos constitucionais está a educação. O Estado é obrigado, devido a Constituição Federal, a implantar ações que sejam capazes de criar condições de garantirem a igualdade de direitos a todos os cidadãos. Os direitos são universais, e somente o Estado tem condições de instituí-los mediante suas ações, ou seja, por meio de políticas públicas. Pelo fato de as desigualdades existentes no acesso à educação pública no campo serem muito grandes, isto obriga o Estado, respeitando a constituição, implantar políticas específicas que sejam capazes de minimizar os prejuízos já sofridos pela população do campo por terem sidos privados historicamente do direito à educação escolar (MOLINA, 2012).

No território das políticas públicas de Educação do Campo, temos o PRONERA. De acordo com o Manual de Operações do PRONERA, o Programa Nacional de Educação na Reforma Agrária é uma política pública de Educação do Campo desenvolvida nas áreas de Reforma Agrária. Seu principal objetivo é fortalecer o meio rural enquanto território de vida em todas as suas dimensões: econômicas, sociais, políticas, culturais e éticas. O Programa nasceu em 1998 da luta das representações dos movimentos sociais e sindicais do campo. A implantação deste programa permitiu que milhares de jovens e adultos, trabalhadores 
A QUESTÃO AGRÁRIA NO BRASIL: CAMPESINATO, AGRICULTURA FAMILIAR E AGRONEGÓCIO

das áreas de Reforma Agrária tenham o direito do acesso a diferentes níveis de ensino (BRASIL, 2011).

O PRONERA compreende hoje as ações de alfabetização de jovens e adultos, escolarização nos níveis fundamental, médio, superior e pós-graduação, formação continuada de professores, formação técnico-profissional para a saúde, a comunicação, a produção agropecuária e a gestão do empreendimento rural. Todas estas modalidades de educação estão pautadas em metodologias de ensino adequadas a realidade sociocultural do campo (ANDRADE; DI PIERRO, 2004).

Sob influência teórica-política-ideológica do PRONERA se origina o Programa de Apoio à Formação Superior em Licenciatura em Educação do Campo (PROCAMPO). Surge como apoio à implantação de cursos regulares de licenciatura em Educação do Campo nas instituições públicas de ensino superior para a formação de educadores para a docência nos anos finais do ensino fundamental e ensino médio em escolas do campo. A oferta de cursos de licenciatura específicos para a qualificação dos professores do campo começou em 2006, com um projeto-piloto desenvolvido pelas universidades federais de Minas Gerais (UFMG), da Bahia (UFBA) e de Sergipe (UFS) e da Universidade de Brasília (UnB) (BRASIL, 2018)

Estes programas são a construção teórico-prática da Educação do Campo. Ele está vinculado ao Movimento da Articulação Nacional por uma Educação do Campo, atualmente, Fórum Nacional de Educação do Campo (FONEC). Os dois movimentos fazem parte do mesmo tempo histórico. Funciona como uma espécie de indutor da própria reflexão e de muitas ações da Educação do Campo. $O$ objetivo central é a construção de uma educação adequada à lógica do trabalho e da cultura nos territórios dos povos do campo em busca de outra forma de desenvolvimento (MOLINA, 2004; CAMACHO, 2014).

É uma experiência inovadora na medida em que foi implantada num território marcado historicamente pela exclusão social e ausência de políticas públicas na 7 Disponível em: http://portal.mec.gov.br/component/tags/tag/32257. 
área da educação. Podemos afirmar que o mesmo auxilia como instrumento para a construção de outra forma de desenvolvimento territorial no campo com mais equidade e sustentabilidade, tendo em vista que este já propiciou a formação educacional de milhares de jovens no campo (BRASIL, 2011; CAMACHO, 2014).

Esta política pública é constituída numa parceria entre universidades, movimentos sociais e governo federal, representado pelo Instituto Nacional de CoIonização e Reforma Agrária (INCRA), ou seja, este programa se constrói por meio de um modelo de gestão tripartite. Demonstrando um avanço na gestão democrática das políticas públicas no país. Seus projetos se orientam por cinco princípios fundamentais: a inclusão, a participação, a interatividade, a multiplicação e a parceria (BRASIL, 2011; CAMACHO, 2014).

\section{RESULTADOS E DISCUSSÃO}

\section{A FORMAÇÃO DE EDUCADORES DO CAMPO PELO CEGEO/PRONERA E LEDUC/PROCAMPO}

Uma experiência importante de formação de educadores do campo foi o Curso Especial de Graduação em Geografia (CEGeo). Este curso foi construído junto com os militantes dos movimentos socioterritoriais camponeses, estabelecendo-se uma relação entre Universidade, Movimentos Sociais e o Estado por meio do PRONERA. O PRONERA foi a política pública que permitiu a materialização na prática da Educação do Campo. Uma conquista da luta dos movimentos socioterritoriais camponeses.

Este curso foi organizado a partir de uma parceria construída entre a Via Campesina - Brasil; a Escola Nacional Florestan Fernandes (ENFF); a Faculdade de Ciências e Tecnologia da Universidade Estadual Paulista "Júlio Mesquita FiIho" (UNESP - Campus de Presidente Prudente); o Ministério do Desenvolvimento Agrário (MDA) e Instituto Nacional de Colonização e Reforma Agrária (INCRA) por meio do Programa Nacional de Educação na Reforma Agrária (PRONERA). 
A QUESTÃO AGRÁRIA NO BRASIL: CAMPESINATO, AGRICULTURA FAMILIAR E AGRONEGÓCIO

A turma nomeada pelos educandos-camponeses de Milton Santos, contava inicialmente, em 2006, com 60 estudantes, no qual destes se formaram 46 em 2011. Todos representando movimentos sociais ligados a Via Campesina - Brasil: Movimento dos Trabalhadores Rurais Sem Terra (MST), Movimento dos Pequenos Agricultores (MPA), Movimento dos Atingidos por Barragens (MAB), Movimento de Mulheres Camponesas (MMC), Pastoral da Juventude Rural (PJR), Rede de Amigos e Colaboradores das Escolas Família Agrícola do Espírito Santo (RACEFAES), Movimento dos Trabalhadores Sem Teto de São Paulo (MTST SP), Educação e Cidadania de Afrodescendentes e Carentes (EDUCAFRO) e o Movimento Consulta Popular (MCP).

Este curso teve como metodologia a Pedagogia da Alternância, ou seja, alternava o entre os territórios educativos (ANTUNES-ROCHA; MARTINS, 2012) do Tempo Escola (TE) ou Tempo Universidade (TU) com o Tempo Comunidade (TC). Sendo que os Tempos Escolas ocorriam em janeiro e fevereiro na Universidade Estadual Paulista em Presidente Prudente/SP e em julho e agosto na Escola Nacional Florestan Fernandes - ENFF em Guararema/SP.

Caracterizado por uma gestão interinstitucional na forma e no conteúdo, nos cursos do PRONERA, os pressupostos pedagógico-metodológicos são definidos a partir de um tripé: a demanda dos movimentos sociais, a colaboração proposta pelas instituições de ensino superior e a definição de uma política pública encaminhada para responder a essa demanda. A formulação e a prática dos cursos devem estar vinculadas aos princípios da participação, cooperação, responsabilização, diálogo, avaliação e autoavaliação contínuas (UNESP, 2005).

Na perspectiva dos cursos do PRONERA, os princípios presentes no Projeto Político-Pedagógico do CEGeo foram: a docência como princípio articulador das atividades pedagógicas, a sólida formação teórica, o compromisso profissional com a realidade, a experiência prática como princípio articulador das atividades, a pesquisa como princípio formativo e a educação como estratégia para o desenvolvimento sustentável. 
A QUESTÃO AGRÁRIA NO BRASIL: CAMPESINATO, AGRICULTURA FAMILIAR E AGRONEGÓCIO

A análise do Projeto Político-Pedagógico do Curso Especial de Graduação em Geografia, juntamente com o trabalho de campo que fizemos, com a observação participante e com as entrevistas com monitores, coordenadores, professores etc., nos permite afirmar que o CEGeo segue a lógica dos cursos superiores do PRONERA, com uma característica muito marcante de participação dos movimentos sociais na tomada de decisões.

Os conhecimentos adquiridos no CEGeo formaram: educadores-professores que vão auxiliar no desenvolvimento territorial de sua comunidade, refletindo acerca das problemáticas sociais e ambientais; professores-assentados militantes dos movimentos sociais, ou seja, sujeitos com a dimensão de intelectual orgânico; professores que trabalharão na perspectiva do Paradigma da Educação do Campo;

No Curso de Licenciatura em Educação do Campo (LEDUC) na Universidade Federal da Grande Dourados (UFGD), o grau acadêmico conferido é de Licenciado em Educação do Campo com Habilitação em Ciências da Natureza ou Licenciado em Educação do Campo com Habilitação em Ciências Humanas (UFGD, 2014).

O Projeto Pedagógico Curricular (PPC) do curso traz como princípios: a "Pedagogia da Alternância", a organicidade com os movimentos socioterritoriais camponeses e o contexto local. A perspectiva teórico-metodológica tem como base as experiências de Educação Popular embasadas, principalmente, na Pedagogia Freireana, que trazem como preocupação pedagógica o vínculo às comunidades camponesas, e os conhecimentos pedagógicos locais como ponto de partida do processo formativo, estabelecendo-se, assim, uma relação dialógica com o saber técnico-científico.

O PPC também traz a preocupação do desenvolvimento territorial com sustentabilidade no campo em todas as suas dimensões: ambiental, econômica, política, cultural e social em oposição ao modelo de desenvolvimento econômico hegemônico (UFGD, 2014). Os objetivos do curso são: 
Formar licenciados/as em Ciências da Natureza e Ciências Humanas com uma sólida formação humanística, que sejam capazes de atuar como profissionais críticos/as da realidade multidimensional da sociedade brasileira, do processo educacional e nas organizações dos movimentos sociais, habilitando-os/as a produzir conhecimentos que resultem em práticas de docência, lideranças de movimentos sociais, pesquisas e intervenções sócio educacionais.

Para conhecermos uma parte dos resultados dessa formação de educadores-camponeses, vejamos o que a educanda-camponesa do CEGeo, militante do MST e professora-coordenadora, conta como é a sua experiência na escola estadual de seu assentamento, a E.E Valdício Barbosa dos Santos, no estado do Espírito Santo. Ela diz que é uma escola que busca a interação com toda a comunidade. Lá, eles conseguiram implantar a proposta de educação do MST, metodologia do plano de estudos e dos temas geradores.

Todas as escolas de assentamento do norte do Espírito Santo, a gente trabalha através do plano de estudo, que é a metodologia da proposta de educação do MST na escola, e a gente trabalha através dos temas geradores. [...]. (Rn, ENFF, jul. 2010).

Ambas experiencias demonstram a importância de formação específica de educadores para lecionar nas escolas de Educação Básica do Campo.

\section{CONCLUSÃO}

As experiências de Educação do Campo que estão sendo desenvolvidas a partir do PRONERA e PROCAMPO permitem que visualizemos o protagonismo da sociedade civil organizada que está construindo uma nova visão sobre o Estado, o Campo/Campesinato, a Educação, a Universidade e a Democracia.

Permite a formação de um intelectual orgânico com instrumentos suficientes para contribuir para o desenvolvimento socioterritorial junto a sua comunidade por meio da elaboração de políticas públicas, no planejamento socioterritorial do assentamento, na prática docente em sala de aula, na militância dos movimentos socioterritoriais etc. 


\section{REFERENCIAS}

ANDRADE, Márcia Regina; DI PIERRO, Maria Clara. A construção de uma política de educação na reforma agrária. In: ANDRADE, Marcia Regina; PIERRÔ, Maria Clara Di; MOLINA, Mônica Castagna; JESUS, Sonia Meire Santos Azevedo de et al (Orgs.). A educação na Reforma Agrária em perspectiva. São Paulo: Ação Educativa; Brasília: PRONERA, 2004a. p. 19-54.

ANUNES-ROCHA, Maria Isabel; MARTINS, Maria de Fátima Almeida. Tempo Escola e Tempo Comunidade: territórios educativos na Educação do Campo. In: ANUNES-ROCHA, Maria Isabel; MARTINS, Maria de Fátima Almeida; MARTINS, Aracy Alves (Orgs.). Territórios Educativos na Educação do Campo: escola, comunidade e movimentos sociais. Belo Horizonte: Autêntica, 2012. p. 21-36. (Caminhos da Educação do Campo, 05).

ARROYO, Miguel G.; CALDART, Roseli S.; MOLINA, Mônica C. Apresentação. In: (org.). Por uma educação do campo. Petrópolis: Vozes, 2004. p. 7-18.

ARROYO, Miguel Gonzalez. Políticas de formação de educadores (as) do campo. Cad. Cedes, Campinas, vol. 27, n. 72, p. 157-176, mai./ago. 2007. Disponível em: <http://www.cedes.unicamp.br>. Acesso em: 09 jul. 2012.

BATISTA, Maria do Socorro Xavier. Movimentos sociais e educação popular do campo $(\mathrm{Re})$ constituindo Território e a Identidade Camponesa. In: JEZINE, Edineide; ALMEIDA, Maria de Lourdes Pinto de. (Orgs.). Educação e movimentos sociais: novos olhares. Campinas: Alínea, 2007. p. 169-190.

BRASIL. Ministério do Desenvolvimento Agrário - MDA. Instituto Nacional de CoIonização e Reforma Agrária - INCRA. Programa Nacional de Educação na Reforma Agrária (PRONERA). Manual de Operações do Pronera. Brasília: MDA/ INCRA, 2011.

CALDART, Roseli Salete. Educação do campo: notas para uma análise de percurso. In: MOLINA, Mônica Castagna (Org.). Educação do campo e pesquisa II: questões para reflexão. Brasília - DF: MDA/MEC, 2010. p. 103-126. (Série NEAD Debate, 20).

CALDART, Roseli Salete. Pedagogia do Movimento Sem Terra. 3. ed. São Paulo: Expressão Popular, 2004. 
CAMACHO, Rodrigo Simão. Paradigmas em disputa na educação do campo. 2014. 806 p. Tese (Doutorado em Geografia) - Faculdade de Ciências e Tecnologia, Universidade Estadual Paulista "Júlio Mesquita Filho", Presidente Prudente, 2014.

FREIRE, Paulo. Pedagogia do oprimido. 13. ed. Rio Janeiro: Paz e Terra, 1983.

MOLINA, Mônica Castagna. Políticas Públicas. In: CALDART, Roseli Salete et al. (Orgs.). Dicionário da Educação do Campo. Rio de Janeiro: Escola Politécnica de Saúde Joaquim Venâncio; São Paulo: Expressão Popular, 2012. p. 587-596.

MOLINA, Mônica Castagna. Pronera como construção prática e teórica da educação do campo. In: ANDRADE, Marcia Regina; PIERRÔ, Maria Clara Di; MOLINA, Mônica Castagna; JESUS, Sonia Meire Santos Azevedo de et al (Orgs.). A educação na Reforma Agrária em perspectiva. São Paulo: Ação Educativa; Brasília: PRONERA, 2004. p. 61-85.

MOLINA, Mônica Castagna; ANUNES-ROCHA, Maria Isabel. Revista Reflexão e Ação, Santa Cruz do Sul, v.22, n.2, p.220-253, jul./dez.2014.

SÁ, Lais Mourão; MOLINA, Mônica Castagna. Políticas de educação superior no campo. In: MOLINA, Mônica Castagna (Org.). Educação do campo e pesquisa II: questões para reflexão. Brasília - DF: MDA/MEC, 2010. p. 74-83. (Série NEAD Debate, 20).

UFGD. FAIND. Curso de Licenciatura em Educação do Campo - Habilitação em Ciências da Natureza e Ciências Humanas. Projeto Pedagógico Curricular, Dourados: [S.N], 2014.

UNESP. Faculdade de Ciências e Tecnologia. Universidade Estadual Paulista. Curso de geografia: licenciatura e bacharelado. Projeto Político-Pedagógico. Presidente Prudente, 2005. (não publicado). 


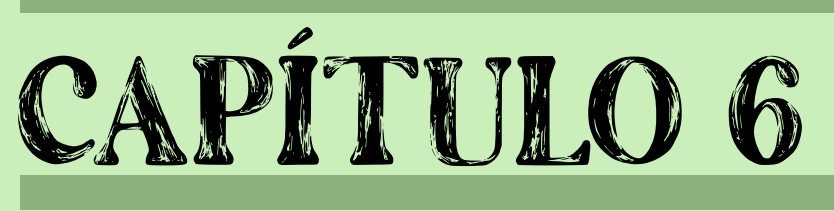

\title{
A ATUAÇÃO DAS CENTRAIS DE
}

\section{ABASTECIMENTO E DAS} COOPERATIVAS NA COMERCIALIZAÇÃO DE PRODUTOS AGRÍCOLAS NO BRASIL1

\author{
Larissa Oliveira Dionisio \\ Antonio Nivaldo Hespanhol
}

$1 \quad$ Este artigo foi apresentado e publicado em Anais do IX Simpósio Internacional e X Simpósio Nacional de Geografia Agrária. 


\section{INTRODUÇÃO}

A ruína do comércio mundial e a queda das oligarquias brasileiras provocadas pela crise de 1929 levaram o Estado brasileiro a incentivar as cooperativas agrícolas, por meio do Decreto 22.239 de 1932. O referido decreto estabeleceu que as cooperativas em formação teriam sua fundação facilitada e que as que já existiam, passariam a ser isentas do pagamento de alguns impostos. As cooperativas de cafeicultores, especificamente, transformaram-se em instrumentos da política agrícola do Estado, deixando de ser um movimento legítimo dos produtores, já que para serem contempladas com investimentos públicos, tiveram que se sujeitar a um maior controle estatal.

As centrais de abastecimento foram criadas nos anos 1960 com o objetivo de facilitar a distribuição e regular os preços dos alimentos, promovendo a ligação direta entre os produtores e consumidores finais. Atualmente, entretanto, as centrais de abastecimento são utilizadas predominantemente por intermediários que comercializam alimentos em grandes quantidades. Já as cooperativas foram criadas como alternativa para a superação da crise econômica da década de 1930, sendo que o seu principal efeito foi reduzir a atuação do capital mercantil na comercialização de produtos agrícolas.

O objetivo do trabalho é analisar as vantagens e desvantagens das centrais de abastecimento e das cooperativas na comercialização de produtos agrícolas, estabelecendo comparação entre ambas.

Para o desenvolvimento da pesquisa foram realizados os seguintes procedimentos metodológicos: levantamento bibliográfico sobre a história das centrais de abastecimento e das cooperativas. Levantamento de dados constantes em publicações da Associação Brasileira de Centrais de Abastecimento (ABRACEN); da própria Companhia de Entrepostos e Armazéns Gerais de São Paulo (CEAGESP); da Companhia Nacional de Abastecimento (CONAB); bem como de dados e informações constantes em documentos do Instituto Brasileiro de Geo- 
A QUESTÃO AGRÁRIA NO BRASIL: CAMPESINATO, AGRICULTURA FAMILIAR E AGRONEGÓCIO

grafia e Estatística (IBGE); do Portal do Cooperativismo Financeiro (COOP); da Organização das Cooperativas Brasileiras (OCB) e da Organização Internacional do Trabalho (OIT).

\section{A Atuação das Centrais de Abastecimento}

Gazolla (2018) salienta que os sistemas de provisão alimentar evoluíram da escala local para a global ao longo da história, nas sociedades constituídas por camponeses, estes tinham a função do abastecimento de vilas, povoados e pequenas cidades e as etapas da produção eram locais. Contudo, principalmente com o crescimento populacional, houve a ampliação da agricultura modernizada resultando no aumento da produtividade e entrada de intermediários nas cadeias de distribuição, devido à necessidade de abastecer um grande número de pessoas, de forma eficaz.

Ocorreram três grandes crises no setor agroalimentar do Brasil, sendo a primeira em 1918, a segunda em 1937 e a terceira em 1962, resultando na adoção de medidas de reestruturação do sistema pelo Estado. Conforme Serra (2013), a crise econômica de 1930 impactou o comércio mundial, por conseguinte sua ruína, e a queda da oligarquia agrária brasileira. A crise internacional foi superada somente na década de 1950, quando o Brasil se adequou ao novo modelo econômico vigente à medida que sua economia foi alterada para se moldar ao mercado externo, direcionando-o para a substituição de importações, definido pela acumulação de capital internacional e estímulo ao desenvolvimento do Complexo Agroindustrial (CAI).

A crise na distribuição dos alimentos motivou a instalação das centrais de abastecimento (CEASA). Queiroz (2014) salienta que a criação das CEASAs se deu em 1968, a partir do Grupo Executivo de Modernização do Abastecimento (Gemab). O advento das centrais de abastecimento se deu por iniciativa governamental. Para Medeiros (2013) as políticas públicas vão muito mais adiante do que as políticas governamentais, já que as políticas públicas visam solucionar um 
problema público e que o governo não é a única instituição a elaborá-las, podendo ser traçadas pelo Estado e/ou por instituições privadas.

Foram as dificuldades na constituição dos preços e na distribuição dos produtos que levaram o Governo Federal a criar as centrais de abastecimento, o que culminou na amplificação da demanda por produtos hortifrutigranjeiros. Santos (1988) ressalta que a modernização acelerada e o incremento da produtividade e do volume produzido requereram a ampliação da capacidade de armazenagem.

Segundo Santos (2000), a agricultura demandou técnica, informação e ciência, resultando na elevação dos níveis de produtividade, pois as mudanças no capitalismo provocaram alterações nas formas de produção, bem como no perfil do mercado consumidor.

Gazolla (2018) evidencia que os problemas do sistema alimentar concentrado pelas cadeias longas começaram a aparecer com o passar do tempo, destacando-se: a instabilidade dos preços, a não identificação da origem, qualidade duvidosa dos alimentos e o excesso de processamentos dos produtos alimentícios. De acordo com Belik e Cunha (2015), os governos militares visavam estabelecer a promoção da integração entre consumidores finais, produtores rurais e varejistas, bem como facilitar o abastecimento das grandes cidades, incentivando os mercados atacadistas.

A Companhia Brasileira de Alimentos (COBAL) e o Sistema Nacional de Centrais de Abastecimento (SINAC) viabilizaram a implementação de 21 unidades da CEASA em diversas cidades do país. As primeiras CEASAs foram criadas entre os anos de 1972 e 1974, no âmbito do I Plano de Desenvolvimento Nacional (I PND). No período de vigência do II Plano Nacional de Desenvolvimento, entre 1975 e 1979, foram instalados outros 19 entrepostos das CEASAS, conforme se verifica no quadro 1. 
Quadro 1 - Ano de instalação das primeiras centrais de abastecimentos nas cidades brasileiras

\begin{tabular}{|c|c|}
\hline Ano & Cidades que foram implementadas a CEASA \\
\hline 1972 & $\begin{array}{c}\text { Brasília - DF } \\
\text { Fortaleza - CE } \\
\text { Recife - PE } \\
\text { Rio de Janeiro - RJ } \\
\text { São Gonçalves - RJ }\end{array}$ \\
\hline 1973 & $\begin{array}{c}\text { Aracaju - SE } \\
\text { Porto Alegre - RS } \\
\text { Salvador - BA }\end{array}$ \\
\hline 1974 & $\begin{array}{c}\text { Belo Horizonte - MG } \\
\text { João Pessoa - PB }\end{array}$ \\
\hline 1975 & $\begin{array}{c}\text { Belém - PA } \\
\text { Campinas - SP } \\
\text { Goiânia - GO } \\
\text { Maceió - AL } \\
\text { Manaus - AM } \\
\text { Natal - RN }\end{array}$ \\
\hline 1976 & $\begin{array}{c}\text { Campina Grande - PB } \\
\text { Curitiba - PR } \\
\text { Teresina - PI } \\
\end{array}$ \\
\hline 1977 & $\begin{array}{c}\text { Mossoró - MA } \\
\text { São Luís - RN } \\
\text { Vitória - BA }\end{array}$ \\
\hline 1978 & $\begin{array}{c}\text { Anápolis - GO } \\
\text { Florianópolis - SC } \\
\text { Foz do Iguaçu - PR } \\
\text { Novo Hamburgo - RS }\end{array}$ \\
\hline 1979 & $\begin{array}{c}\text { Campo Grande- MS } \\
\text { Campos - RJ } \\
\text { Juiz de Fora - MG }\end{array}$ \\
\hline
\end{tabular}

Fonte: Abracen (2011). 
A QUESTÃO AGRÁRIA NO BRASIL: CAMPESINATO, AGRICULTURA FAMILIAR E AGRONEGÓCIO

Em 1982 ainda foram implantadas unidades da CEASA em Cascavel e Londrina, no Estado do Paraná, além de Caxias do Sul, no Rio Grande do Sul, e Macaé, no Estado do Rio de Janeiro.

Na década de 1990, segundo a Companhia Nacional de Abastecimento CONAB (2017), a maior parte das CEASAs passou a ser gerida pelos estados e municípios, enquanto apenas as centrais de Minas Gerais (CeasaMinas) e de São Paulo (CEAGESP) ficaram sob responsabilidade federal.

Queiroz (2014) salienta que as centrais de abastecimento são instituições integradas por um conjunto de intermediários, visto que são firmas atacadistas e de atravessadores hortifrutigranjeiros. Carvalho e Pinheiro (2010) enfatizam que as centrais de abastecimento são instituições baseadas em experiências europeias, sobretudo espanhola e francesa.

De acordo com dados da CONAB (2017), os agricultores que mais operam nas CEASAs são de pequeno porte ou em sistema familiar, ao passo que as CEASAs constituem-se em plataformas logísticas de comercialização. No entanto, a figura do atravessador ou intermediário é muito presente, em razão de transportar e fornecer alimentos.

As centrais de abastecimento possuíam como missão possibilitar a comercialização direta de produtos agrícolas pelos produtores rurais, contudo em "São Paulo e Rio de Janeiro a maioria da comercialização é feita por atravessadores" (MAZON, 2010, apud VEDANA, 2012, p. 2).

Anjos e Becker (2014) ressaltam que até meados da década de 1970, os produtores familiares possuíam acesso facilitado aos mercados locais pela venda direta aos consumidores em feiras regionais ou por meio de atravessadores, que compravam dos produtores. Belik e Cunha (2015) evidenciam que esse era o papel original das centrais de abastecimento, isto é, possibilitar a comercialização direta de hortifrutigranjeiros pelos produtores.

Ainda que os atravessadores estejam muito presentes, as centrais de abastecimento propiciaram a maior integração de pequenos produtores rurais ao 
mercado, possibilitando a comercialização direta, conforme enfatizam Gomes e Antonialli (2005).

Bengozi et al. (2007) evidenciam que as centrais de abastecimento oferecem estabilidade na quantidade comercializada, sua produção provem de hortas, pomares e demais empreendimentos agrícolas. Lorenzani e Silva (2004) apud Firetti et al (2011), por sua vez, ressaltam que a maior parte dos produtos hortícolas é comercializada por intermédios que atuam nas centrais de abastecimento, as quais são responsáveis pelo suprimento de cozinhas industriais, hotéis, penitenciárias e supermercados.

As centrais de abastecimento favorecem as cadeias produtivas, visto que, de acordo com a Associação Brasileira das Centrais de Abastecimento (ABRACEN, 2011), em virtude de oferecerem um conjunto de serviços até então inexistente e desestruturado, como a capacitação de agentes, informações de mercado, padronização e classificação dos produtos, incentivo à produção para a exportação etc. Carvalho e Pinheiro (2010) salientam que as centrais de abastecimento devem ser tratadas como componente operacional do sistema, já que nelas ocorrem a armazenagem, manuseio e movimentação dos produtos hortifrutigranjeiros, havendo grande fluxo de veículos.

Santos (2008) evidencia que no estado de São Paulo, as grandes transformações na organização do espaço foram resultado da expansão da agroindústria, da rápida substituição de cultivos e das novas localizações das indústrias.

Segundo Santos (1988), a produção direta ocorre localmente, já que as agroindústrias introduzem a possibilidade de participar de uma lógica extralocal, tendo em vista que tais empresas necessitam de tecnologias, informações, capitais e altos lucros, relacionando-se com grandes centros em vínculos cada vez mais extralocais.

Segundo Muller (1993) a modernização agrária diz respeito à alteração no modo de produzir tradicional para o modo industrial, bem como na sociabilidade. Ainda que com um caráter de segregação, as centrais de abastecimento foram 
importantes agentes desse processo de modernização ao estipular quantidades mínimas para serem comercializados nas suas unidades, tendo, contudo, um viés que colocou os pequenos produtores à margem do sistema.

\section{A Atuação das cooperativas}

De acordo com Rocha (1999), o movimento cooperativo teve seu advento em movimentos sociais, no período do liberalismo econômico, no século XVIII, influenciado pela Revolução Industrial. Seu principal pressuposto se assentava no trabalho em grupo e na equidade e na liberdade, sendo que a cooperação surgiu como uma alternativa, cujo objetivo era combater as injustiças sociais, em razão da competição que era um dos princípios do liberalismo econômico. A primeira cooperativa da história foi fundada em 1844, por um grupo de tecelões de Rochdale, na Inglaterra, denominada "Rochdale Quitable Pioneers Society Limited" ou "Sociedade dos Probos Pioneiros de Rochdale".

De acordo com o Portal do Cooperativismo Financeiro (COOP, 2019) foi estabelecido um estatuto social para a primeira cooperativa, o qual regulamentava normas igualitárias e democráticas para sua constituição, princípios estes que são seguidos até hoje de forma adaptada. Atualmente os princípios que regem o cooperativismo são os seguintes:

1. Adesão voluntária e livre - As cooperativas são abertas para todas as pessoas que queiram participar, estejam alinhadas ao seu objetivo econômico, e dispostas a assumir suas responsabilidades como membro. Não existe qualquer discriminação por sexo, raça, classe, crença ou ideologia.

2. Gestão democrática - As cooperativas são organizações democráticas controladas por todos os seus membros, que participam ativamente na formulação de suas políticas e na tomada de decisões. E os representantes oficiais são eleitos por todo o grupo.

3. Participação econômica dos membros - Em uma cooperativa, os membros contribuem equitativamente para o capital da organização. Parte do montante é, normalmente, propriedade comum da cooperativa e os membros recebem remuneração limitada ao capital integralizado, quando há. Os excedentes da cooperativa podem ser destinados às seguintes finalidades: benefícios aos 
membros, apoio a outras atividades aprovadas pelos cooperados ou para o desenvolvimento da própria cooperativa. Tudo sempre decidido democraticamente.

4. Autonomia e independência - As cooperativas são organizações autônomas, de ajuda mútua, controladas por seus membros, e nada deve mudar isso. Se uma cooperativa firmar acordos com outras organizações, públicas ou privadas, deve fazer em condições de assegurar o controle democrático pelos membros e a sua autonomia.

5. Educação, formação e informação - Ser cooperativista é se comprometer com o futuro dos cooperados, do movimento e das comunidades. As cooperativas promovem a educação e a formação para que seus membros e trabalhadores possam contribuir para o desenvolvimento dos negócios e, consequentemente, dos lugares onde estão presentes. Além disso, oferece informações para o público em geral, especialmente jovens, sobre a natureza e vantagens do cooperativismo.

6. Intercooperação - Cooperativismo é trabalhar em conjunto. É assim, atuando juntas, que as cooperativas dão mais força ao movimento e servem de forma mais eficaz aos cooperados. Sejam unidas em estruturas locais, regionais, nacionais ou até mesmo internacionais, o objetivo é sempre se juntar em torno de um bem comum.

7. Interesse pela comunidade - Contribuir para o desenvolvimento sustentável das comunidades é algo natural ao cooperativismo. As cooperativas fazem isso por meio de políticas aprovadas pelos membros (Organização das Cooperativas Brasileiras, 2019).

Segundo Serra (2013), foi a partir da década de 1930, quando houve a devastação do comércio mundial, bem como o declínio da oligarquia agrária, decorrente da crise, que o Estado brasileiro teve que transformar seu modelo de desenvolvimento econômico. Uma das iniciativas adotadas pelo Estado brasileiro foi incentivar o funcionamento de cooperativas agrícolas, a partir do decreto 22.239, de 1932.

O referido decreto estipulava que as cooperativas em formação teriam sua fundação viabilizada e que as que já existiam, teriam isenções de impostos. Para Serra (2013), principalmente as que tinham relação com a cafeicultura, transfor- 
mar-se-iam em instrumentos da política agrícola do Estado, deixando de ser um movimento legítimo dos produtores, já que para se sujeitar aos investimentos do setor industrial, as cooperativas dependeriam mais do Estado. Assim, o Estado aplicaria recursos públicos nas cooperativas, promovendo a sua transformação em empresas agroindustriais, no entanto, exerceria maior controle sobre elas.

(...) as cooperativas efetivamente se integram ao Complexo Agroindustrial, tornam- se eficientes no papel de agentes modernizadores da agricultura, passam a se sobrepor ao capital internacional no setor agroindustrial, mas perdem uma nova fatia de sua autonomia (SERRA, 2013, p. 18).

A Organização Internacional do Trabalho (OIT) divulgou em 2002, a recomendação 193, definindo cooperativa como: "associação autônoma de pessoas que se unem voluntariamente para atender a suas necessidades e aspirações comuns, econômicas, sociais e culturais, por meio de empreendimento de propriedade comum e de gestão democrática" (OIT, 2002).

As cooperativas deveriam ser

Altamente eficientes, acompanhando e alavancando a eficiência do pró-
prio setor agrícola que passa a se modernizar com a incorporação dos
bens gerados pela indústria à sua montante e, ao mesmo tempo se es-
truturando para garantir a fatia de mercado no setor agroindustrial, à sua
jusante. Em relação à agricultura propriamente dita, o papel das coopera-
tivas passa a ser estruturado em função da orientação e assistência téc-
nica aos agricultores associados, ao fornecimento de sementes e outros
insumos agrícolas, ao recebimento da produção colhida e à proposta e
defesa de políticas agrícolas. Em relação ao setor de transformação, a
participação vai além de uma simples prestação de serviços: passa a
depender de pesados investimentos para a implantação de indústrias,
cujos montantes em muitos casos superavam a capacidade econômica e
financeira das empresas e, algumas vezes, seu próprio patrimônio (SER-
RA, 2013, p. 17-18).

De acordo com Serra (2013), em 1969 o Ministério da Agricultura organizou o IV Congresso Brasileiro de Cooperativismo, sendo que ao final do evento foi criada a Organização das Cooperativas Brasileiras (OCB) e extintas a Aliança Brasileira de Cooperativas (ABCOOP) e a União Nacional das Associações Cooperativas (UNASCO). Isto fez com que as cooperativas tivessem uma represen- 
tação unificada, ainda que a ingerência do Estado continuasse significativa na definição das políticas agrícolas envolvendo a participação das cooperativas.

No decorrer dos anos 1970 foram feitos grandes investimentos na modernização da agricultura brasileira, por meio principalmente da concessão de empréstimo para investimento e o custeio das safras, o que favoreceu também as cooperativas, sendo a elas disponibilizadas linhas especiais de crédito para investimento.

Segundo dados da OCB (2019), em 1971, com a lei 5.764, foram estabelecidos os preceitos para a criação das cooperativas, com regime jurídico próprio que viabilizou a atuação das cooperativas como empresas. A referida lei permitiu a estruturação das cooperativas em treze ramos, cobrindo, assim todos os setores, quais sejam: agropecuária, consumo, crédito, educacional, especial, habitacional, infraestrutura, mineral, produção, saúde, trabalho, turismo e lazer e transporte.

Com a promulgação da nova Constituição Federal no ano de 1988, a interferência do Estado nas cooperativas foi bastante reduzida, iniciando-se, a partir daí, a chamada auto administração das cooperativas, ou seja, elas deixaram de ser fiscalizadas e tuteladas pelo Estado, ao mesmo tempo em que deixaram de ter acesso a recursos públicos em condições altamente favoráveis.

As cooperativas, segundo a OCB (2019), são classificadas de acordo com a dimensãoe os objetivos da organização, existindo três categorias de sociedades cooperativas: a) as de $1^{\circ}$ grau ou singular; b) as de $2^{\circ}$ grau, que são as centrais ou federações de cooperativas; e c) as de $3^{\circ}$ grau ou confederações.

As de $1^{\circ} \mathrm{grau}$ devem ser constituídas por, no mínimo, 20 cooperados, tendo como finalidade o fornecimento direto de serviços aos associados e é permitida a adesão de pessoa jurídica desde que não atue no mesmo âmbito econômico da cooperativa. As de $2^{\circ}$ grau são formadas por no mínimo três cooperativas singulares ou de $1^{\circ}$ grau e têm por objetivo regular a escala de serviços da filiada, 
A QUESTÃO AGRÁRIA NO BRASIL: CAMPESINATO, AGRICULTURA FAMILIAR E AGRONEGÓCIO

auxiliando na utilização dos mesmos. Por fim, as de $3^{\circ}$ grau também visam facilitar a escala de serviço das filiadas, a diferença principal entre as sociedades cooperativas de $2^{\circ}$ e $3^{\circ}$ graus é que as de $3^{\circ}$ grau são formadas por três cooperativas centrais ou federações, isto é, três cooperativas de $2^{\circ}$ grau de qualquer ramo.

De acordo com Rocha (1999), as cooperativas têm buscado cada vez mais a diversificação, bem como agregar valor aos produtos dos associados. Contudo, a associação cooperativa estabelece uma valorização mais ampla do homem em relação ao capital, ainda que, como empresa, as cooperativas atuem nas dimensões social e econômica, fazendo operações comerciais e industriais com os produtos captados e prestando serviços ao seu corpo associativo.

\section{CONCLUSÃO}

A crise na distribuição de alimentos estimulou a criação das centrais de abastecimento pelo governo federal, na década de 1970, com o objetivo de fazer a ligação entre consumidores e produtores. Atualmente as centrais de abastecimento se constituem numa importante plataforma logística de comercialização, bem como oferecem estabilidade nas quantidades comercializadas e promovem o controle sobre o abastecimento alimentar dos governos, resultando na facilidade de fiscalização, na implantação de políticas e na regulação da circulação de mercadorias.

As centrais de abastecimento seriam vantajosas aos pequenos produtores se estes conseguissem superar a pequena escala de produção, a falta de padronização e a sazonalidade na produção, ou seja, ainda que seja um elemento fundamental para a circulação, escoamento e distribuição alimentar, as centrais de abastecimento não resolvem o problema dos pequenos produtores, à medida que favorecem e ratificam a presença do intermediário na comercialização dos produtos. Ainda deve ser salientado que nem todos os produtores possuem meios para levar sua produção as centrais, reafirmando a necessidade da presença do atravessador. 
As cooperativas, por sua vez, são empresas que possuem natureza jurídica diferente das demais empresas, sendo que o seu advento se deu fundamentalmente voltado para o consumo. As cooperativas foram responsáveis por organizar a captação de grande volume de produção, combatendo os estrangulamentos na comercialização, por meio da eliminação da figura do intermediário. Algumas cooperativas passaram a agregar valor aos produtos dos seus associados, por meio da industrialização, além de favorecerem o acesso a linhas de créditos específicos ao seu corpo associativo.

Ademais, as cooperativas usufruíram de sua relação umbilical com o Estado, constituindo grandes parques industriais que contribuíram para solidificar os complexos agroindustriais por meio da captação, transferência e transformação de matérias primas em produtos industrializados, ratificando-se como empresa agroindustrial, já que seguem a lógica de mercado, ou seja, comprando em grandes quantidades a preços menores e vendendo em grandes quantidades, agregando um preço maior ao produto.

As cooperativas apresentam maior vantagem aos seus associados do que as centrais de abastecimento em relação aos seus permissionários. As cooperativas, além de eliminarem a atuação dos intermediários, organizam e agregam valor a produção dos associados. No entanto, ao se transformarem em grandes empresas capitalistas, as cooperativas seguem a lógica de mercado e provocam o afastamento dos seus associados, especialmente dos pequenos produtores rurais.

\section{AGRADECIMENTOS}

Agradeço à Fundação de Amparo à Pesquisa do Estado de São Paulo (FAPESP) pela concessão da bolsa de pesquisa que possibilitou a elaboração do artigo. 


\section{REFERENCIAS}

ANJOS, F. S.; BECKER, C. Agricultura Familiar e Mercados Institucionais: o desenvolvimento como liberdade. Revista Econômica. Fortaleza, v. 45, p. 92-101, 2014.

BELIK, W.; CUNHA, A. R. A. A. Abastecimento no Brasil: o desafio de alimentar cidades e promover o desenvolvimento rural. In: GRISA, C.; SCHNEIDER, S. (Org.). Políticas públicas no desenvolvimento do Brasil. Porto Alegre: Editora da UFRGS, 2015, p. 217-235.

BENGOZI, F. J. Análise do mercado de abacaxi comercializado na CEAGESP São Paulo. Revista brasileira de fruticultura. Jaboticabal, v. 20, n. 3, 2007, p. 494-499.

CARVALHO, M. V. G. S. A.; PINHEIRO, A. M. G. S. A logística do abastecimento na RMB: o caso CEASA. In: TOBIAS, M. S. G.; NETO, B. C.. (Org.). Grande Belém: faces e desafios de uma metrópole insular. $1^{\mathrm{a}}$ ed. Belém: Ponto Press Ltda., 2010, v. 01, p. 25-48.

COOP - Portal do Cooperativismo Financeiro, 2019. Disponível: https://cooperativismodecredito.coop.br/. Acessado em: 11 de Jun. 2019.

FIRETTI, R.et al. Participação de organizações sociais na gestão de entrepostos de abastecimento: o caso da Ceasa/PR em Londrina. Informações Econômicas, São Paulo, v. 41, n.4, 2011, p. 64-72.

GAZOLLA, M. Devemos ir para casa comer? As possibilidades do abastecimento local. 2018. Disponível em: https://www.sul21.com.br/colunas/coluna-do-gepad/2018/05/devemos-ir-para-casa-comer-as-possibilidades-do-abastecimento-local/. Acessado em: 29 de Mai. 2019.

GOMES, M. E. S.; ANTONIALLI, L. M.; COSTA, C. C. Caracterização dos produtores rurais de Minas Gerais ofertantes da CEASA. In: CONGRESSO DA SOBER, 43. , 2005, Ribeirão Preto. Anais... Ribeirão Preto: SOBER, 2005.

HARVEY, D. A globalização contemporânea. In: Espaços de esperança. São Paulo: Edições Loyola, 2004, p. 79 - 103.

HESPANHOL, A. N. Políticas públicas, modernização e crise da agricultura brasileira. Faz ciência. Francisco Beltrão, FACIBEL, v. 1 n. 1, p. 38-49, 1997. 
MEDEIROS, A. M. Políticas Públicas, 2013. Disponível em: http://www.portalconscienciapolitica.com.br/ci\%C3\%AAncia-politica/politicas-publicas/. Acessado em; 29 de Abr. 2019.

MÜLLER, G. Brasil agrário: heranças e tendências. São Paulo em Perspectiva, São Paulo, v. 7, n. 3, Jul-Set 1993, p. 11-20.

OCB - Sistema OCB. Disponível em: https://www.ocb.org.br/o-que-e-cooperativismo. Acessado em: 30 de abr. 2019.

OIT - Organização Internacional do Trabalho. R193-Sobre a Promoção de Cooperativas. Disponível em:<< http://www.ilo.org/brasilia/convencoes/WCMS_242764/ lang--pt/index.htm. Acessado em: 15 de Jun. 2019.

QUEIROZ, T. A. N. A CEASA-RN e os circuitos da economia urbana: a circulação de hortifrutigranjeiros em Natal-RN, 2014, 148 f. Dissertação (Mestrado em Geografia) - Universidade Federal do Rio Grande do Norte, Universidade do Rio Grande do Norte, Rio Grande do Norte.

SANTOS, M. Metamorfoses do espaço habitado: fundamentos teóricos e metodológicos da geografia. Hucitec. São Paulo, 1988, 124 p.

SANTOS, M. Por uma outra globalização: do pensamento único à consciência universal. $6^{a}$ ed. Rio de Janeiro: Record, 2000, 174 p.

SANTOS, M. O espaço dividido: Os dois circuitos da economia urbana dos países subdesenvolvidos. Trad. Myrna T. Rego Viana. $2^{a}$ Ed., $1^{a}$ reimpr. São Paulo: Editora da Universidade de São Paulo, 2008, 440 p. (Coleção Milton Santos4) (Primeira Edição, 1979)a.

SERRA, E. A participação do Estado na formação e desenvolvimento das cooperativas agrícolas no Brasil. CAMPO-TERRITÓRIO: revista de geografia agrária, v. 8, n.16, ago. 2013, p.6-37.

VEDANA, V. Trabalhado e abastecimento urbano: pesquisa etnográfica sobre o trabalho no comércio de alimentos na CEASA/RS In: ENCONTRO ANUAL DA ANPOCS, 36. , 2012, Águas de Lindóia, Anais... Águas de Lindóia: Associação Nacional de Pós-Graduação e Pesquisa em Ciências Sociais, 2012, p. 1-20. 
dol 10.48209/978-QR-89949-07-6

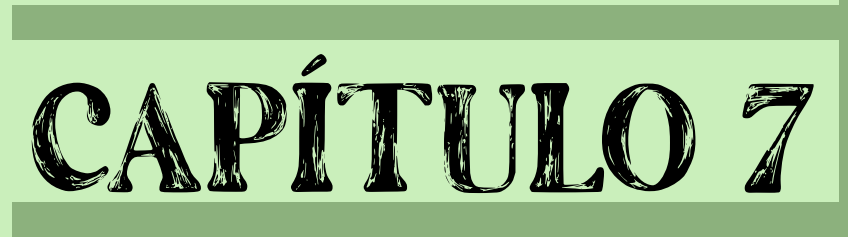

\section{A COMPOSIÇÃO SOCIOESPACIAL} DAS COMUNIDADES QUILOMBOLAS DE GARANHUNS E 0 SEU PROCESSO DE DELIMITAÇÃO TERRITORIAL

Wellington Cesar Barbosa de Lira 


\section{INTRODUÇÃO}

Encravada entre sete colinas numa região planáltica do Agreste Meridional Pernambucano, com aproximadamente mil metros de altitude, apresentando um clima mesotérmico, comparado com a região sul do mediterrâneo, encontra-se a cidade de Garanhuns. Distante $225 \mathrm{Km}$ da capital pernambucana, rica em belas paisagens e fontes de água mineral, é conhecida como a cidade das flores. É também um centro polarizador da região abrigando um diversificado comércio e sendo referência regional nas áreas de saúde e educação.

Contemporânea do período da guerra holandesa e da guerrilha do Quilombo dos Palmares, Garanhuns é marcada pela forte presença de negros fugidos, pois por ordem do Rei todos os quilombos deveriam ser destruídos. Com a forte presença das tropas no litoral esses negros foram cada vez mais adentrando aos agrestes e sertões do nordeste brasileiro, buscando refúgio, principalmente, nas áreas planálticas.

Dessa maneira, nas áreas planálticas do agreste pernambucano, passam a existir redutos de resistência, em similaridade a Palmares. Esses novos quilombos que surgiam nestas áreas, descritas como áreas de florestas e altas serras, serão também alvos das tropas do Rei, que também conseguiu exterminar os quilombos encontrados nas terras de Unhanhu, entre estes o Magano, que hoje dá nome a um bairro de Garanhuns. É nesta fase que se originam as comunidades de Castainho, Caluete, Estivas, Estrela, Timbó e Tigre, não existe definição da data, mas se sabe que é inegável a íntima relação da formação desses com o Quilombo dos Palmares.

É pelo reconhecimento dos seus territórios que as comunidades quilombolas de Garanhuns vem lutando, a busca da definição do seu espaço, e com isso, conseguirem, além da sua autoafirmação enquanto grupo social, demonstrar para o restante da sociedade que eles existem, e são componentes ativos na configuração de todo o complexo social existente. 
A QUESTÃO AGRÁRIA NO BRASIL: CAMPESINATO, AGRICULTURA FAMILIAR E AGRONEGÓCIO

Dessa forma, tem-se como objetivo central desta pesquisa analisar o processo de identificação e delimitação de territórios quilombolas, realizado pela Fundação Cultural Palmares e pelo INCRA no município de Garanhuns-PE, relacionando com a questão identitária e dinâmica socioespacial.

Em virtude de um processo de imediatização e difusão dos meios informacionais atuarem na dinâmica e estruturação da configuração espacial e social recente. Esta se torna uma abordagem relevante, uma vez que se toma como referencial a identificação espacial da sociedade, compreendendo, de modo geral, que sua identidade territorial não está vinculada apenas ao Estado-nação, que atrelada ao efeito da globalização proporciona uma padronização territorial da sociedade.

Neste sentido se pretende contribuir para questões pertinentes ao conceito de identidade, território, e para a questão do processo de delimitação e demarcação dos territórios quilombolas, além de trazer a luz questões de cunho social e prático envolvendo não só as comunidades envolvidas no processo, mas também os agentes operadores da questão do campo no Brasil contemporâneo.

Dessa forma, o processo planejamento, identificação e delimitação dos territórios das comunidades quilombolas de Castainho, Caluete, Estivas, Estrela, Timbó e Tigre se apresentam como um intrigante objeto de análise, uma vez que todo o seu processo de reconhecimento socioespacial encontra-se em construção, tornando-as um elemento desencadeador para a compreensão da dinâmica, territorial e social existente, não só no município de Garanhuns, mas em todo o Agreste Meridional Pernambucano.

Quanto a abordagem, esta pesquisa se classifica como qualitativa, uma vez que se busca analisar as relações sociais estabelecidas entre diversos agentes em meios diferentes. No tocante aos procedimentos, esta pesquisa se classifica como estudo de caso. Em relação ao delineamento da pesquisa, a mesma se classifica como descritiva quanto aos objetivos, uma vez que irá avaliar relacionamento entre duas variáveis e seguirá com a apresentação dos resultados. 
Para a execução da investigação da pergunta central da pesquisa, foram procedidas pesquisas documentais e bibliográficas, além de levantamento de dados em órgãos públicos e privados, bem como levantamento de informações cientificamente relevantes junto as comunidades e aplicação de questionários.

Após a interpretação dos dados obtidos, constatou-se que o processo planejamento, identificação e delimitação dos territórios das comunidades quilombolas do município de Garanhuns se apresenta de modo fundamental no processo de reconhecimento territorial e de uma construção socioespacial, uma vez que contribui para a consolidação das comunidades enquanto entes sociais e fortalece a luta de resistência cultual, valorizando a ancestralidade e sentimento de pertencimento individual e coletivo.

\section{AS COMUNIDADES}

O universo escolhido para o desenvolvimento da pesquisa foram as comunidades quilombolas existentes no município de Garanhuns: Castainho, Caluete, Estivas, Estrela, Timbó e Tigre (mapa 01).

Estas comunidades se apresentam localizadas em áreas rurais desprovidas da maioria dos equipamentos de infraestrutura como: esgoto, iluminação pública, segurança, postos de saúde, escolas, entre outros. O acesso para todas estas comunidades é feito por estradas não asfaltadas, as populações vivem em precárias condições de vida, as comunidades não conseguem se manter economicamente sem os subsídios das diversas esferas governamentais, principalmente do Governo Federal.

É pelo reconhecimento dos seus territórios que as comunidades quilombolas de Garanhuns vem lutando para que elas possam ter a definição do seu espaço, e com isso, conseguirem, além da sua autoafirmação enquanto grupo social, demonstrar para o restante da sociedade que eles existem, e são membros atuantes na configuração de todo o complexo social existente. 
Mapa 01 - localização das comunidades quilombolas no município de Garanhuns
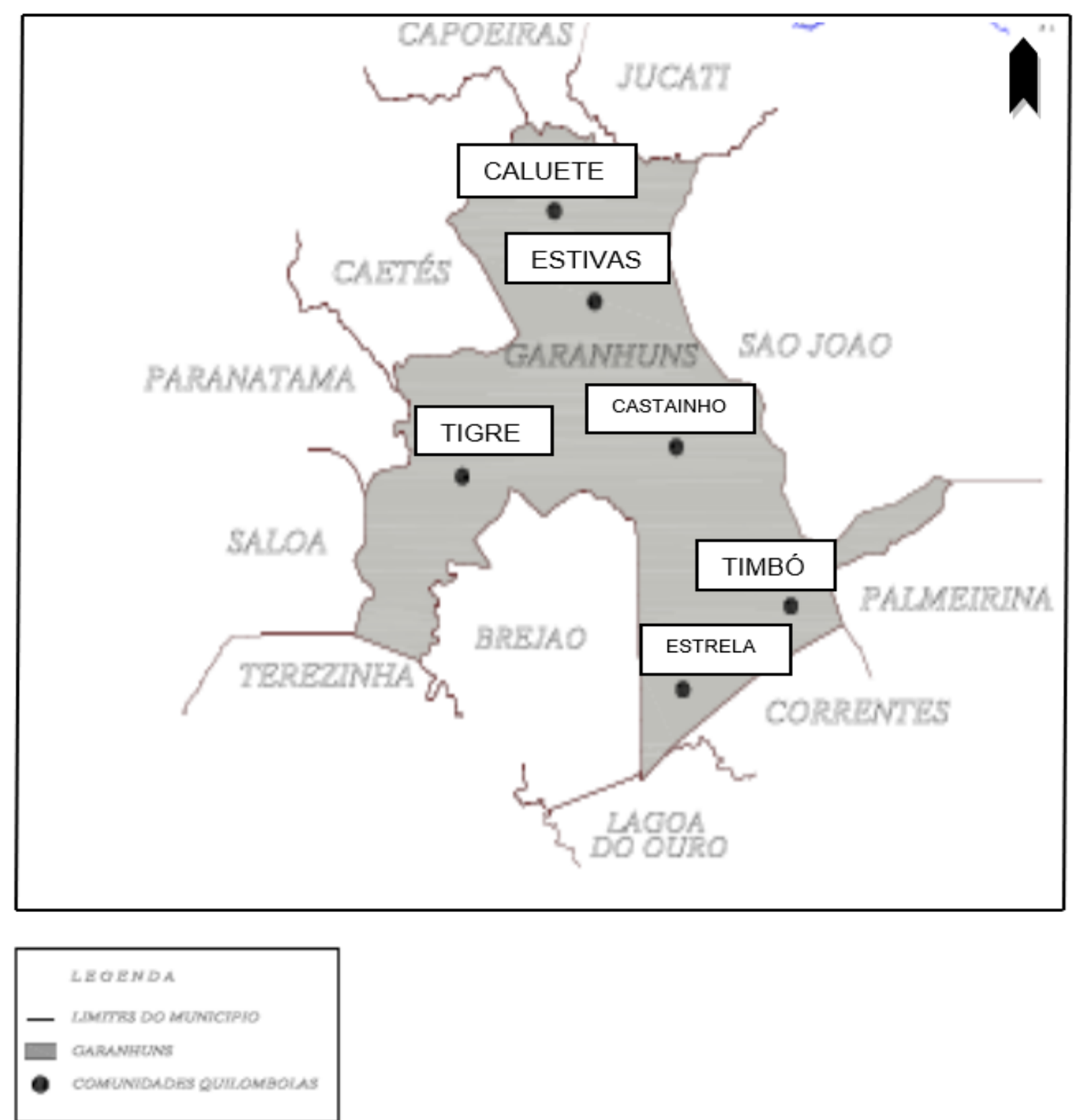

rsches: 1.200,000

Fonte: INCRA SR(03)/PE

\section{FUNDAMENTAÇÃO TEÓRICA}

A elaboração desta pesquisa se pautou em abordagens referentes ao território e a identidade, a fim de promover discussões sobre a formação de uma identidade socioterritorial. Ao utilizar o território como elemento vetorial para promoção de reflexões, faz-se necessário buscar um entendimento etimológico do mesmo. 
A QUESTÃO AGRÁRIA NO BRASIL: CAMPESINATO, AGRICULTURA FAMILIAR E AGRONEGÓCIO

A palavra território é derivada diretamente do vocábulo latino terra, que era utilizado pelo sistema jurídico romano dentro do chamado jus terrendi, como o pedaço de terra apropriado dentro dos limites de uma determinada jurisdição político-administrativa.

Apesar de ser um conceito para a Geografia, território, por fazer referência à espacialidade humana, tem certa tradição também em outras áreas, cada uma com enfoque centrado em uma determinada perspectiva. Enquanto o geógrafo tende a enfatizar a materialidade do território, em suas múltiplas dimensões; a Ciência Política enfatiza a sua construção a partir de relações de poder (na maioria das vezes ligada à concepção de Estado); a Economia, que prefere a noção de espaço à de território, percebe-o muitas vezes como um fator locacional ou como uma das bases da produção (enquanto força produtiva); a Antropologia destaca sua dimensão simbólica, principalmente no estudo das sociedades ditas tradicionais; a Sociologia o enfoca a partir de sua intervenção nas relações sociais, em sentido amplo; a Psicologia incorpora-o no debate sobre a construção da subjetividade ou da identidade pessoal, ampliando-o até a escala do indivíduo; para a Filosofia este se apresenta como conceito-chave atingindo uma noção muito ampla que atinge dimensões que vão do físico ao mental, do social ao psicológico.

Ao buscar uma conceituação para o território podemos identificar a existência de algumas dimensões que usualmente ele é focado, sendo estas realizadas a partir de uma contextualização política, econômica, cultural. Numa perspectiva política o território costuma possuir relações de espaço-poder, em geral, ou jurídico-política, relativas também a todas as relações espaço-poder institucionalizadas. A mais difundida, é aquela que trata o território como um espaço delimitado e controlado, através do qual se exerce um determinado poder, na maioria das vezes, mas não exclusivamente, relacionado ao poder político do Estado. Sobre o ponto de vista econômico, menos difundido, é dada ao território uma ênfase a sua dimensão espacial das relações econômicas, o território é entendido como 
A QUESTÃO AGRÁRIA NO BRASIL: CAMPESINATO, AGRICULTURA FAMILIAR E AGRONEGÓCIO

fonte de recursos e/ou incorporado no embate entre classes sociais e na relação capital-trabalho, como produto da divisão "territorial" do trabalho, por exemplo.

Numa perspectiva cultural e também simbólico-cultural, o território é priorizado com uma dimensão mais subjetiva, sendo visto como um produto da apropriação e valorização simbólica de um grupo em relação ao seu espaço vivido. É importante salientar a diferenciação existente entre essas três dimensões (política, cultural, econômica) com que usualmente o território é focalizado, mas é significativo também buscar uma discussão mais ampliada, levando em consideração que estas dimensões estão inseridas dentro de uma fundamentação filosófica, ficando evidente que uma resposta a estes referenciais irá depender da posição filosófica adotada pelo pesquisador.

Numa abordagem geográfica se podem identificar algumas posições que privilegiam a dimensão econômica na construção do conceito de território. A mais consistente e relevante vem de Santos (2000), que afirma que o uso, prioritariamente econômico, é o definidor por excelência do território, em defesa de uma abordagem geográfica integradora e totalizante. Santos (1994) utiliza a controvertida expressão "território usado" como correlato direto de espaço geográfico, objeto da disciplina geográfica.

Ao definir espaço geográfico como sendo sinônimo de território (território usado), como interação entre um sistema de objetos e um sistema de ações, Santos (1996) explicita a base materialista de fundamentação econômica em seu trabalho. Apesar de criticar as limitações da abordagem analítica em torno da dialética das forças de produção e das relações de produção, ele associa, ainda que de forma simplória, como ele próprio diz, sistema de objetos como um conjunto de forças produtivas e sistema de ações como um conjunto de relações sociais de produção.

Dessa maneira, busca-se uma reflexão que indica que o território não seja visto apenas como o lócus das relações de poder que se fortalecem através de mediações espaciais, mas como um meio de identificação e de reformulação de 
sentidos e de valores. É de acordo com esta concepção que se buscará também tratar a questão de identidade, fundamental para o diálogo com o território na busca de uma construção socioterritorial.

De modo genérico, a identidade será entendida como algo que pode tanto referenciar uma pessoa como um objeto, implicando numa relação de semelhança ou de igualdade. Entretanto, deve-se entender que esta busca do igual, do idêntico, pode ser trocada pela busca do verdadeiro, do autêntico. Para muitos autores a identidade não é vista de modo concreto, ficando restrita ao campo das representações, eminentemente simbólica. Não podemos, neste caso, tratar a identidade de modo imaterial, uma vez que se entende que a sua materialidade pode vir através do território. Assim, estamos buscando a construção de uma identidade socioterritorial. Identificar, no âmbito humano-social, é sempre um processo reflexivo, portanto, identificar-se é sempre um processo de identificar-se com, ou seja, é sempre um processo relacional, diálogo inserido numa relação social, não sendo definido de forma clara, mas como um movimento sempre em curso.

Algumas identidades podem se manifestar em função das condições espaço temporais em que o grupo está inserido buscando um reconhecimento que se faz frente à alteridade, pois é no encontro ou embate com o outro que se busca a afirmação e reconhecimento daquilo que os distinguem podendo, dessa forma, gerar um diálogo ou conflito. Uma das principais questões que envolvem a identidade é a dificuldade de reconhecer o outro, tendendo-se sempre por meio de um processo classificatório o qual padroniza e cria parâmetros únicos de comparação, hierarquizando ou "desigualizando" aquilo que deveria ser visto apenas como diferente. Neste sentido, a diferença identitária, cultural, se dissolve na desigualdade e o extremo desta transformação é o preconceito, onde a diferença do outro acaba se transformando na sua estigmatização, no seu rebaixamento, na sua depreciação. Na realidade, diferença ou alteridade e desigualdade ou comparabilidade não podem ser vistos de forma excludentes, nem de modo a 
que uma se dilua na outra, a fronteira entre o desigual e o diferente é sutil, e o que ora é visto como diferente pode ser visto em outra situação como desigual, ou vice-versa.

Ao buscar o entendimento de uma identidade socioterritorial pode-se também levantar uma discussão sobre símbolo. Uma vez que este mantém numa relação mais direta com a coisa nomeada e ao mesmo tempo mais carregado de subjetividade, possuindo uma abertura capaz de levar a outros sentidos.

Assim, uma das bases que pode dar mais consistência e eficácia ao poder simbólico da identidade são os referencias concretos aos quais se faz referência para ser construída, uma vez que o símbolo necessita sempre de algum referente concreto para se realizar, podendo ser este um recorte ou uma característica espacial, ou neste caso, pode-se ter a construção de uma identidade através do território, constituindo assim, uma identidade socioterritorial.

\section{RESULTADOS E DISCUSSÃO}

De acordo com os dados obtidos pode-se constatar que cada comunidade se reconhee e possui o entendimento de pertencimento ao grupo social ao qual está vinculado, exaltando sua ancestralidade. Entretanto, do ponto de vista de técnico e legal cada comunidade se apresenta em fases de modo distinto, merecendo destaque a comunidade de Castainho, a qual já se encontra na fase de definição do seu território bem como a desintrusão de pessoas não pertencentes à comunidade que estão ocupando terras dentro do território legalmente definido. Está sobre a responsabilidade da Superintendência Regional do INCRA em Pernambuco SR-03, realizar estas ações. De acordo com esta superintendência a fase de georreferenciamento e demarcação de todo o perímetro de Castainho já foi concluída, como demonstrado nas figuras 01 e 02. 
Figura 01 - Rastreamento do perímetro de Castainho

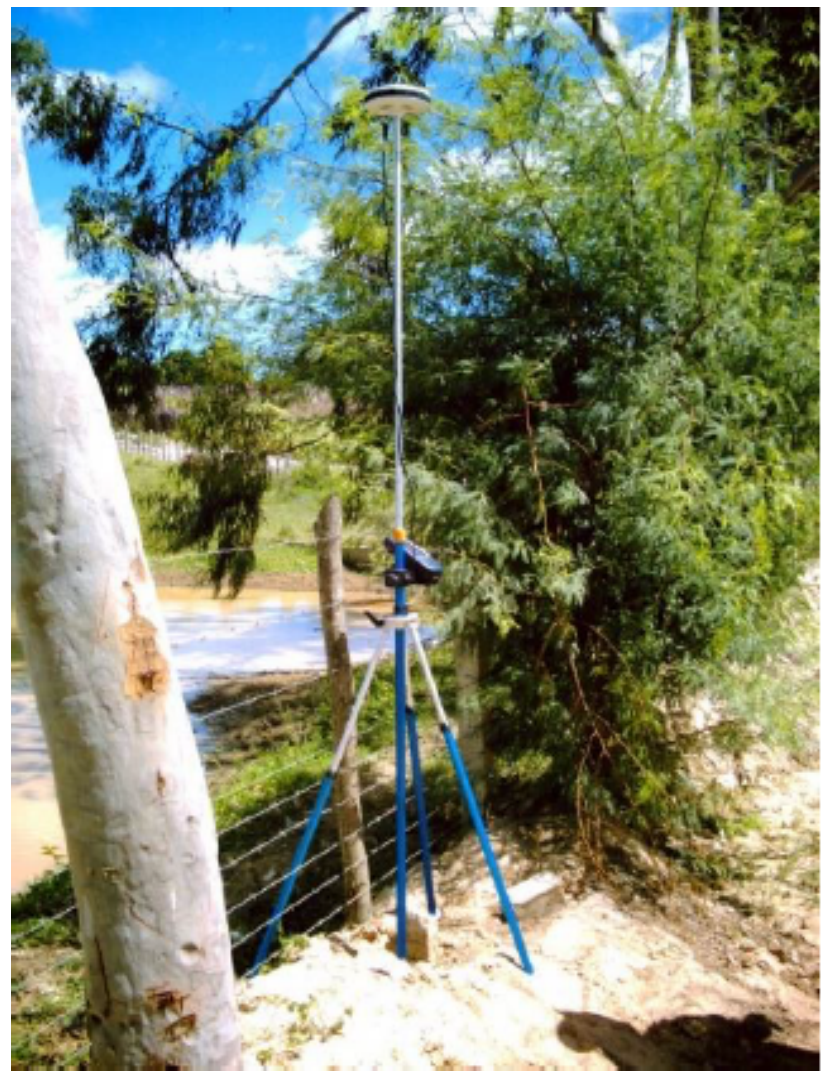

Fonte: Wellington Lira (2008)
Figura 02 - Levantamento das estradas internas

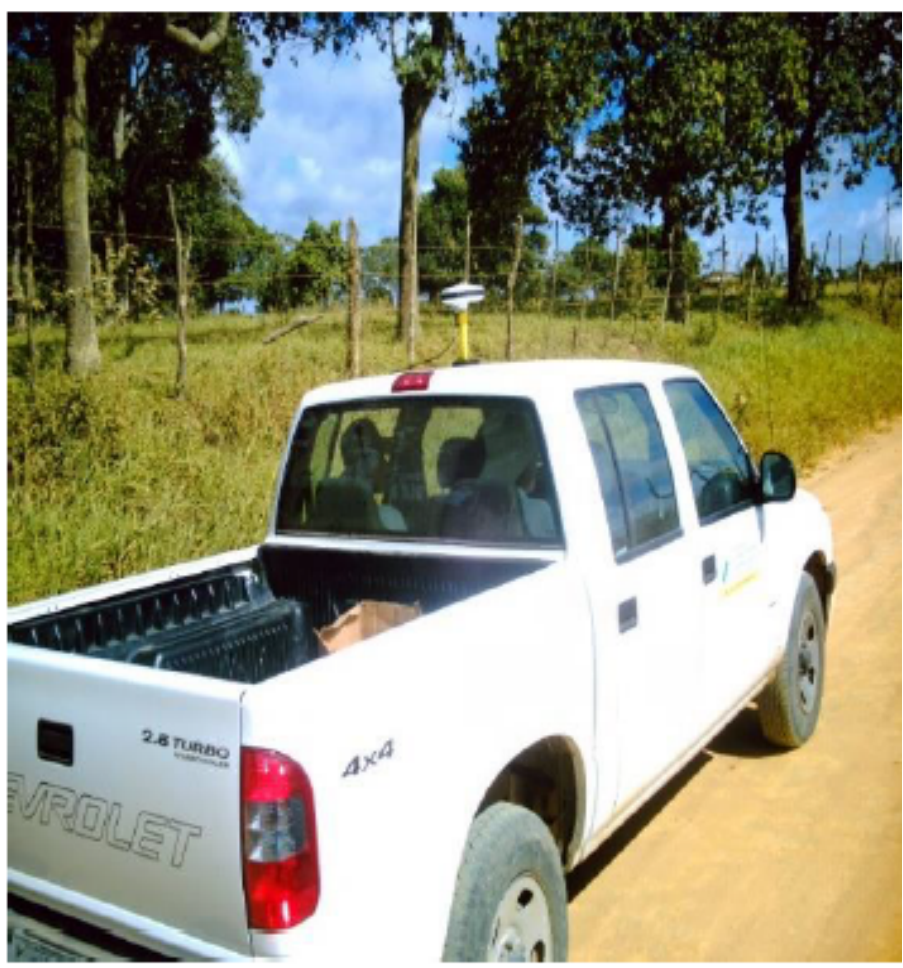

Fonte: Wellington Lira (2008)

De modo geral essas comunidades se caracterizam da seguinte maneira:

Castainho - Distante aproximadamente $3 \mathrm{~km}$ do centro do município de Garanhuns, encurralada pela expansão urbana da cidade que praticamente a reduz a uma periferia, encontra-se Castainho. Atualmente a população de Castainho é de 128 famílias, as quais sobrevivem, essencialmente, de atividades ligadas a agricultura, merecendo destaque ao cultivo da mandioca, onde há seu beneficiamento na casa de farinha da comunidade, além de serem atendidos pelos programas sociais do Governo Federal. No tocante a infraestrutura Castainho possui fornecimento de energia elétrica em todo o seu território, todas as estradas e vias de acesso não são asfaltadas, a comunidade não é atendida pela rede de abastecimento oficial de água (COMPESA), os moradores dispõem de apenas 01 escola de ensino fundamental, e não tem posto de saúde local, e a maioria das casas são de alvenaria. Nas figuras 03 e 04 abaixo, tem-se imagens da escola e sua casa de farinha. 
Figura 03 - vista da escola (esq) Casa de Farinha (dir)

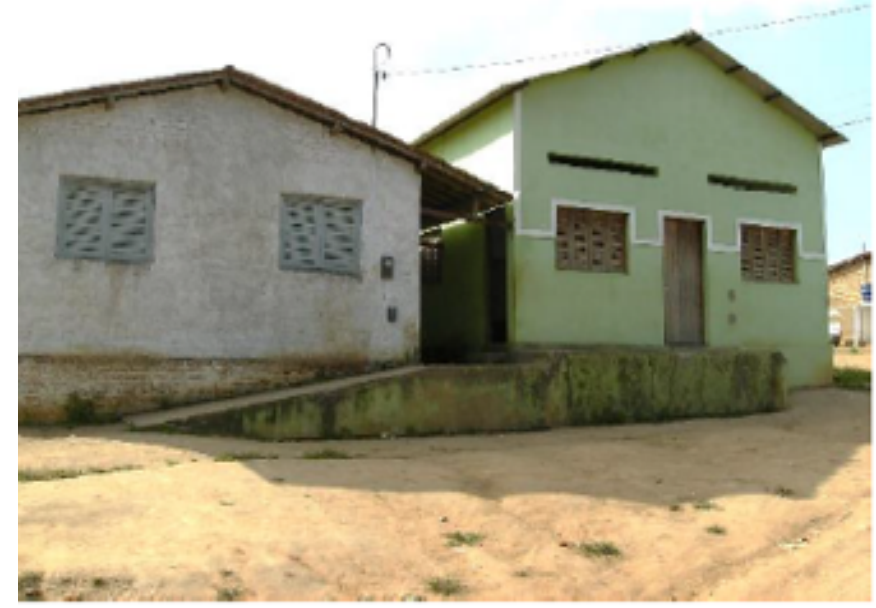

Fonte: Wellington Lira (2018)
Figura 04 - imagem interna da casa de farinha

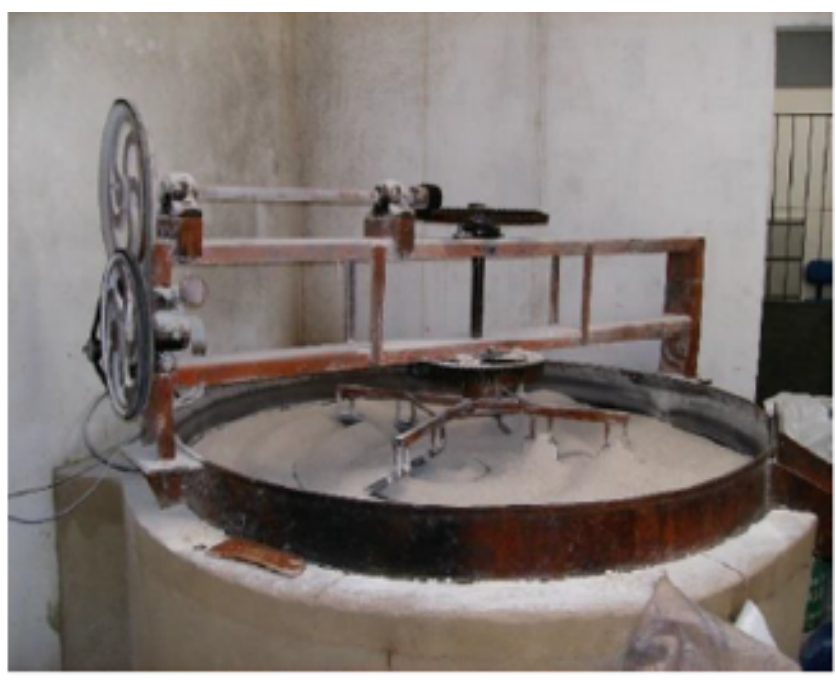

Fonte: Wellington Lira (2018)

Caluete - Distando aproximadamente $17 \mathrm{~km}$ do centro do município de Garanhuns, possuindo uma população aproximadamente de 100 famílias que sobrevivem, essencialmente, dos programas sociais do Governo Federal, da agricultura familiar de subsistência e de aposentadorias. Sua infraestrutura é bastante precária onde não possuem abastecimento de água potável, suas estradas e caminhos não são asfaltados, não possuem escolas nem postos de saúde, nas figuras 05 e 06 , tem-se imagens da comunidade.

Figura 05 - imagem de uma das estradas internas da comunidade

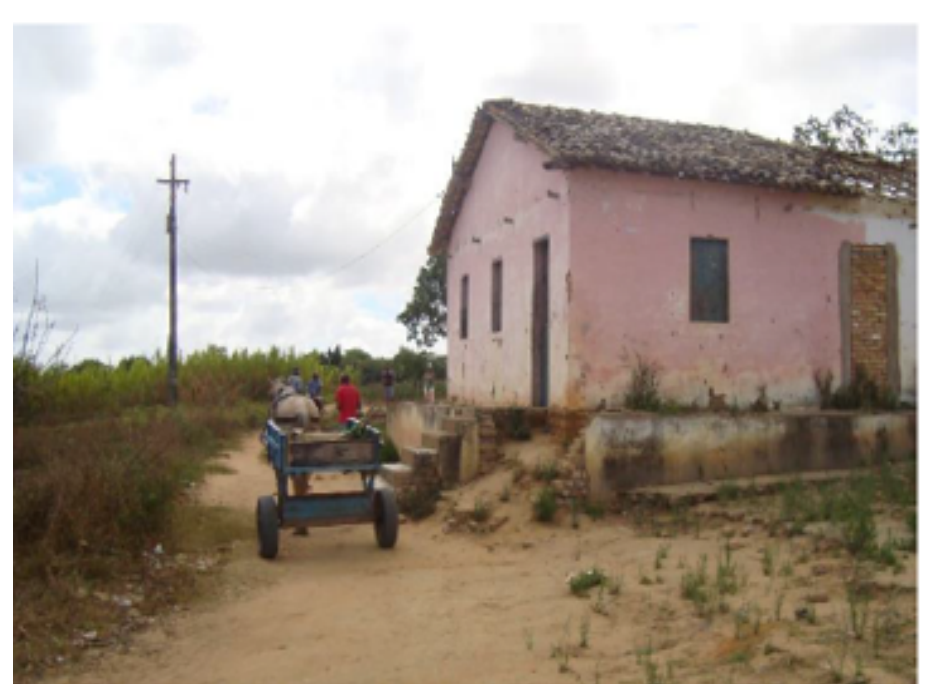

Fonte: Wellington Lira (2018)
Figura 06 - ponto de captação de água da comunidade

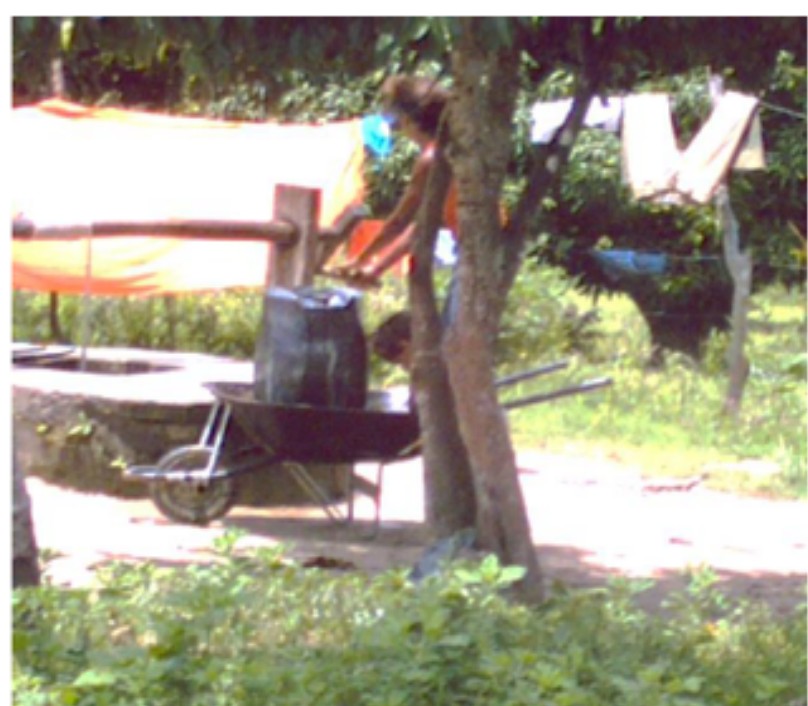

Fonte: Wellington Lira (2018) 
Timbó - Possuindo uma população de aproximadamente 130 famílias, localizada a aproximadamente $30 \mathrm{~km}$ do centro do município de Garanhuns, a comunidade do Timbó é marcada por possuir um núcleo central bem diversificado apresentando entre outros pontos um cemitério e uma área de produção dos tijolos para construção de suas moradias, conforme mostram as figuras 07 a 09. A população local também sobrevive, essencialmente, dos programas sociais do Governo Federal, da agricultura familiar de subsistência, com destaque para o cultivo da mandioca, sendo que sua casa de farinha ainda possui uma estrutura com maquinários muito rudimentar, como visto nas figuras 10 e 11 . Sua infraestrutura não foge ao perfil das outras comunidades onde não possuem abastecimento de água potável, suas estradas e caminhos não são calçados nem asfaltados (figura 12), não possuem postos de saúde.

Figura 07 - vista do núcleo central da comunidade

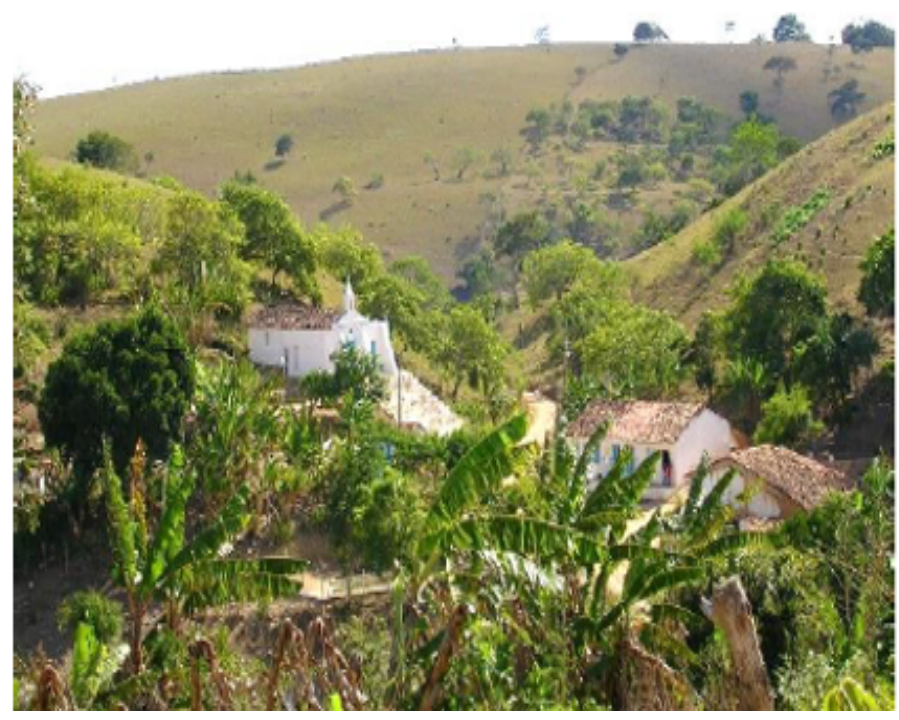

Fonte: Wellington Lira (2018)
Figura 08 - imagem do cemitério da comunidade

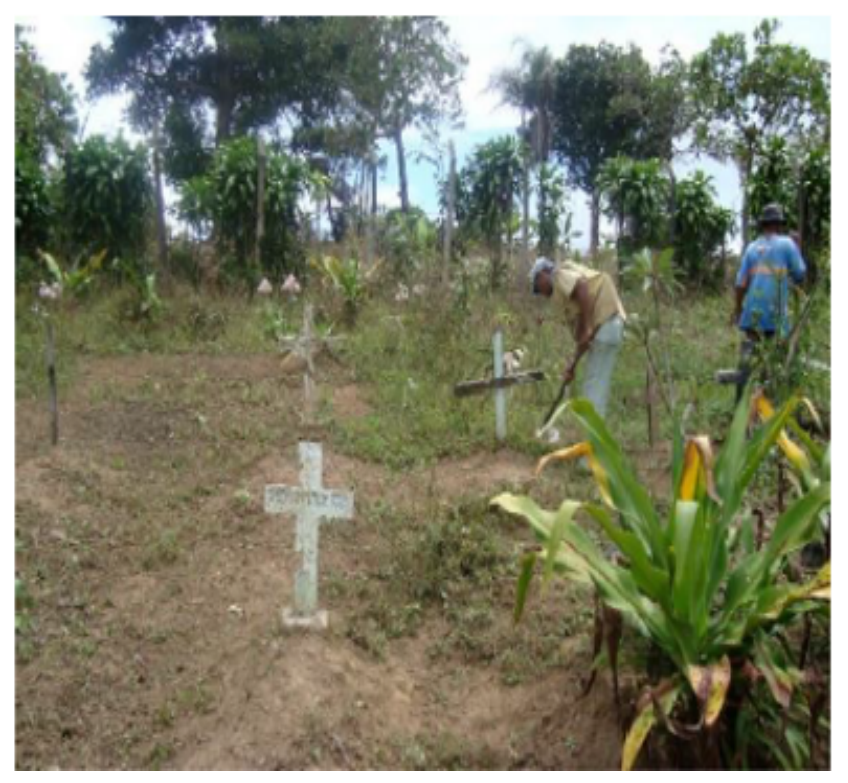

Fonte: Wellington Lira (2018) 
Figura 09 - membros da comunidade na Figura 10 - casa de farinha da comunidade produção artesanal de tijolos

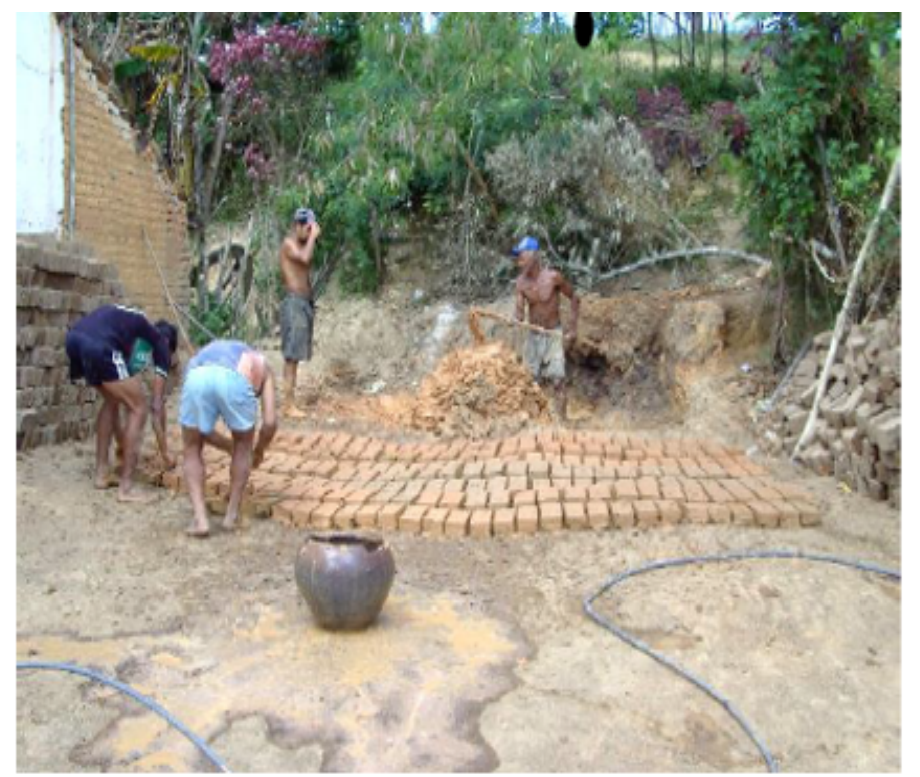

Fonte: Wellington Lira (2018)

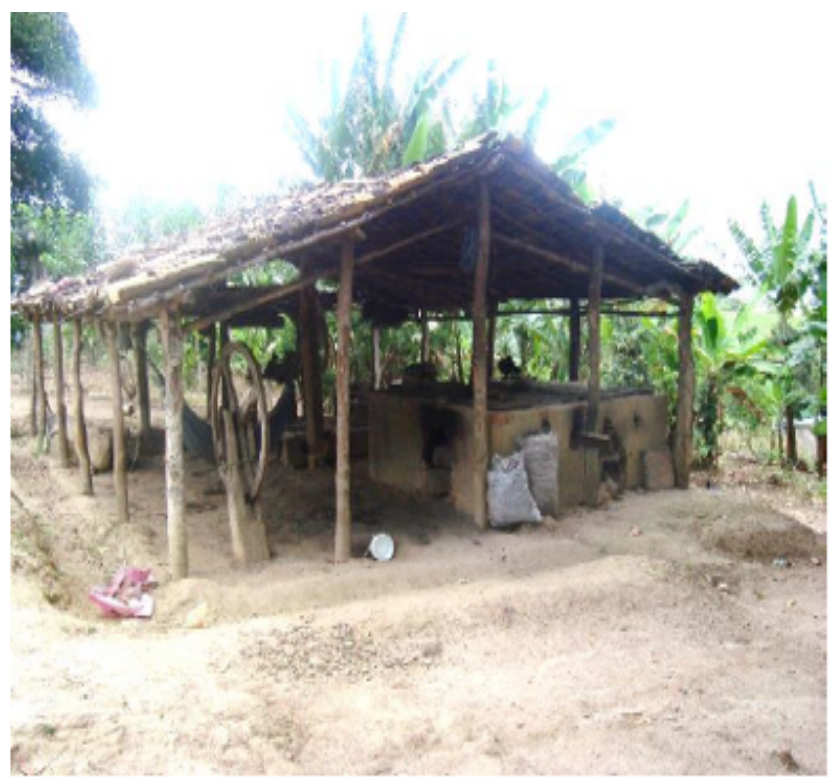

Fonte: Wellington Lira (2018)

Figura 11 - outra casa de farinha da Figura 12 - uma das estradas de acesso a comunidade comunidade

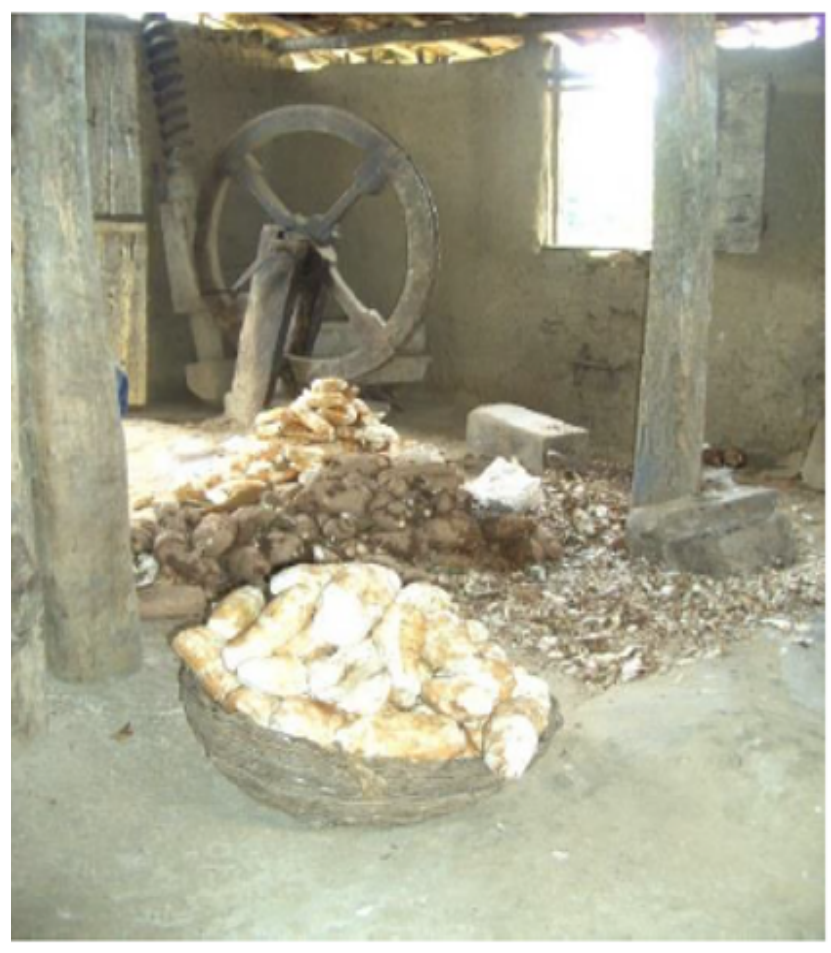

Fonte: Wellington Lira (2018)

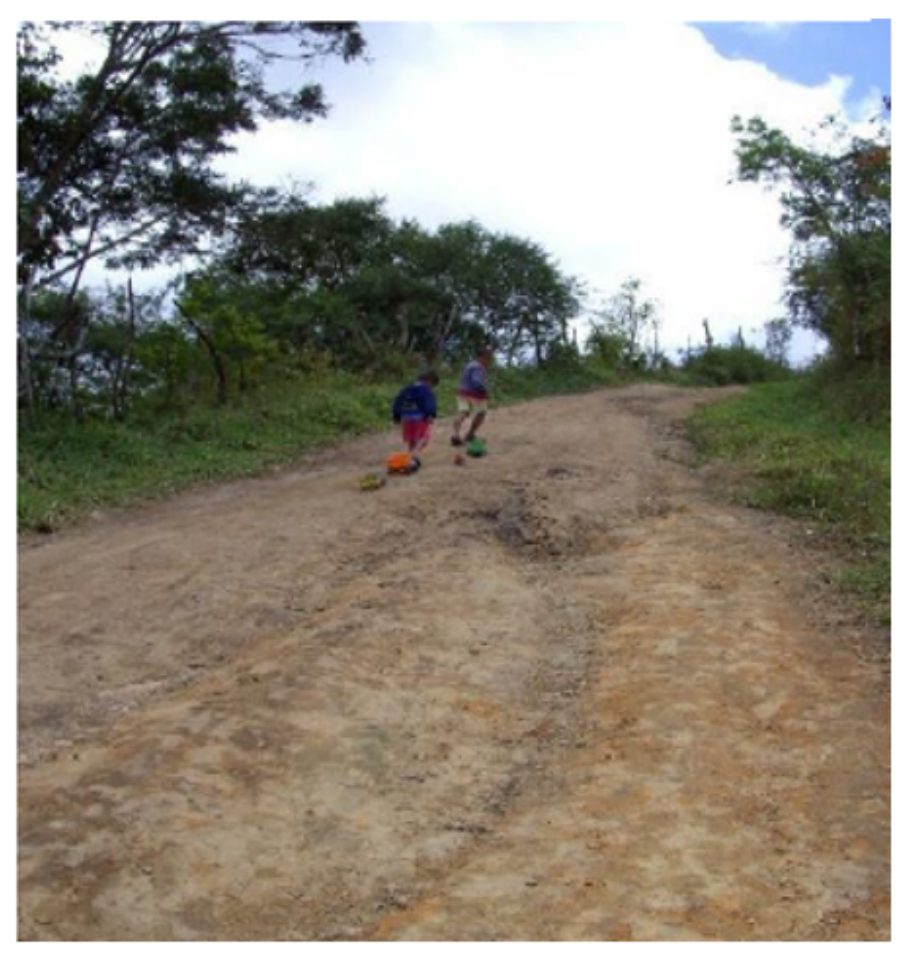

Fonte: Wellington Lira (2018) 
Estrela - localizada a aproximadamente $8 \mathrm{~km}$ do centro do município de Garanhuns, a comunidade de Estrela possuindo uma população entorno de 125 famílias. A sua população também sobrevive, essencialmente, dos programas sociais do Governo Federal, da agricultura familiar de subsistência, do trabalho alugado e de aposentadorias. A infraestrutura da comunidade não foge ao perfil das outras existentes, não possuem abastecimento de água potável, suas estradas e caminhos não são asfaltados, não possuem postos de saúde, mas são atendidos por uma escola municipal de ensino fundamental e pela rede de energia elétrica. Abaixo seguem imagens do núcleo central da comunidade (figura 13) e um "mapa" que eles produziram com a distribuição espacial de culturas e recursos naturais (figura 14).

Figura 13 - núcleo central da comunidade, é marcado pela presença de um templo católico

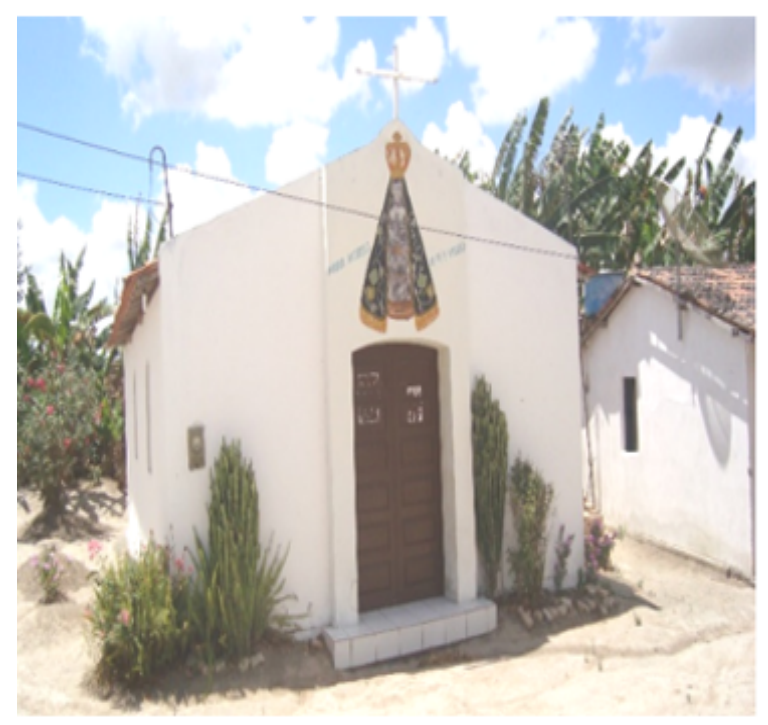

Fonte: Wellington Lira (2018)
Figura 14 - mapa temático produzido pela comunidade

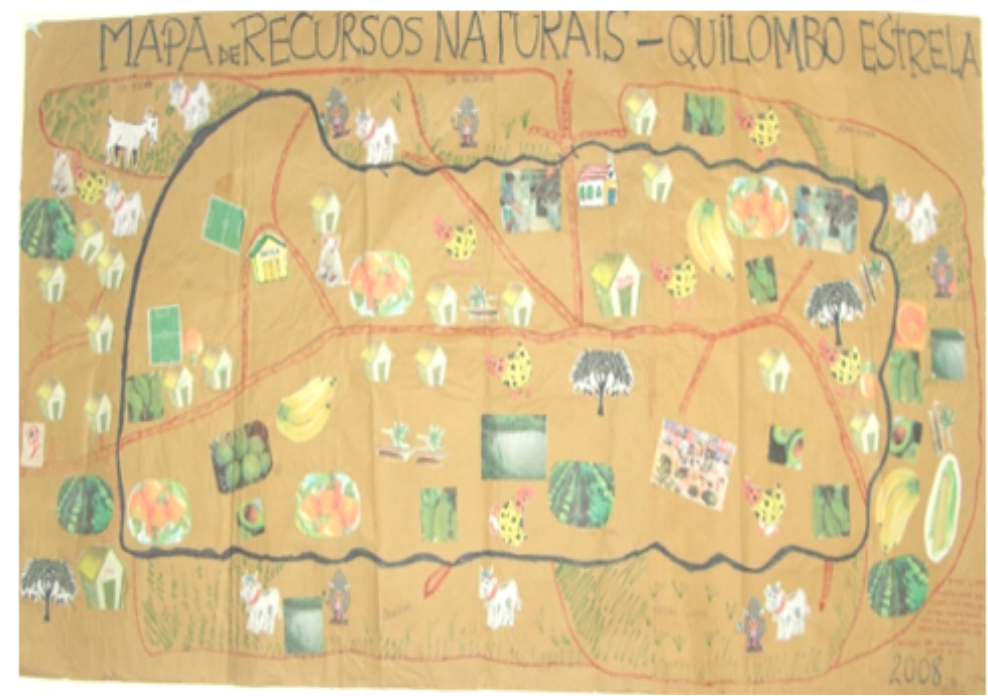

Fonte: Wellington Lira (2018)

Estivas - Distando aproximadamente $4 \mathrm{~km}$ do centro do município de Garanhuns, possuindo uma população aproximadamente de 100 famílias que sobrevivem, essencialmente, dos programas sociais do Governo Federal, da agricultura familiar de subsistência e de aposentadorias. Sua infraestrutura é comum as outras comunidades, não possuem abastecimento de água potável, suas estradas e caminhos não são asfaltados, não possuem postos de saúde e possuem apenas uma escola municipal de ensino fundamental. Nas figuras 15 e 16, a seguir, tem-se imagens da comunidade. 
Figura 15 - cultivo realizado pela comunidade

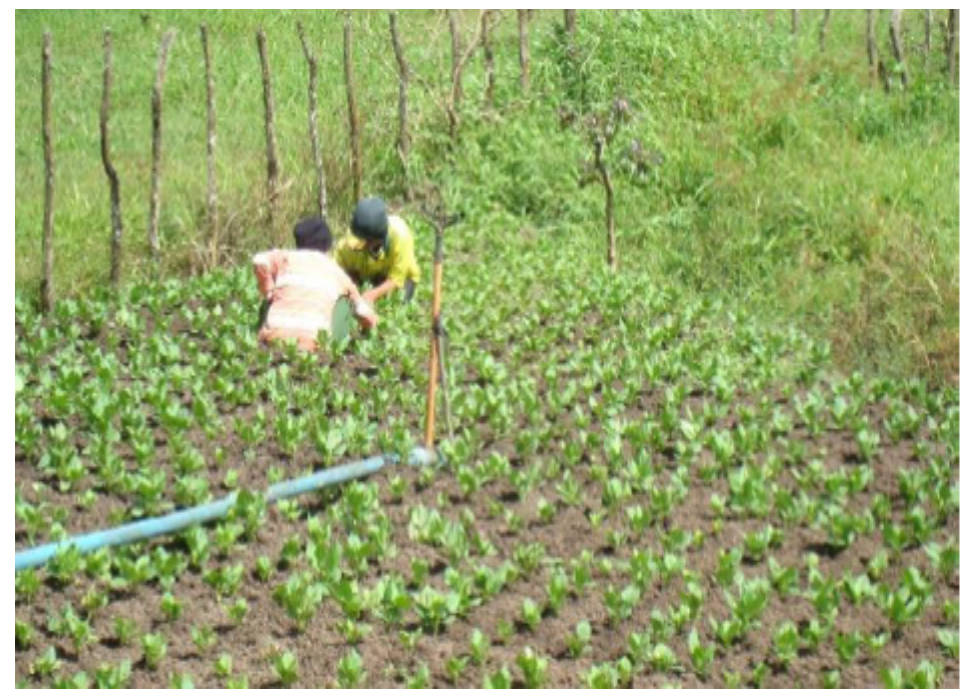

Fonte: Wellington Lira (2018)
Figura 16 - estrada local e meio de transporte comum na comunidade

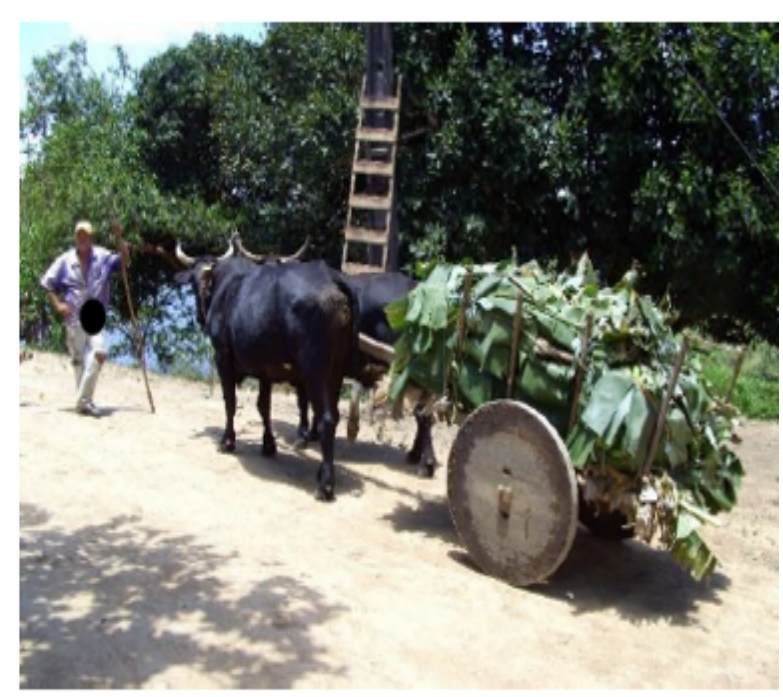

Fonte: Wellington Lira (2018)

Tigre - localizada a aproximadamente $6 \mathrm{~km}$ do centro do município de Garanhuns, a comunidade de Tigre possui uma população aproximadamente de 92 famílias que sobrevivem, essencialmente, dos programas sociais do Governo Federal, da agricultura familiar de subsistência e de aposentadorias. Sua infraestrutura é comum as outras comunidades, não possuem abastecimento de água potável, suas estradas e caminhos não são asfaltados, não possuem postos de saúde e possuem apenas uma escola municipal de ensino fundamental e são atendidos em todo o território pela rede de energia elétrica. Nas figuras 17 e 18, abaixo, tem-se algumas imagens da comunidade.

Figura 17- escola localizada no núcleo Figura 18- cultivo de mandioca em uma central da comunidade. propriedade da comunidade.

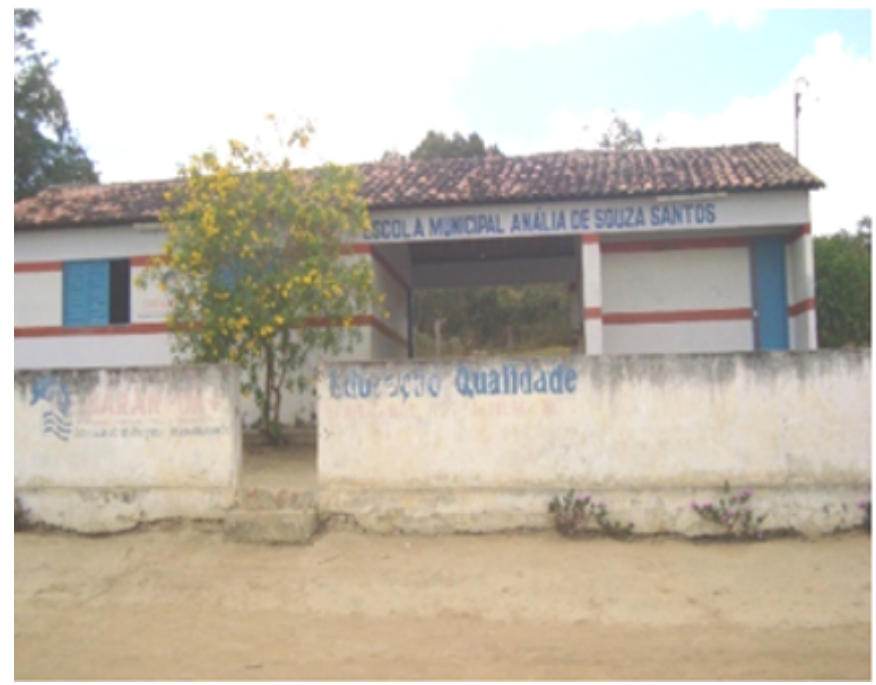

Fonte: Wellington Lira (2018)

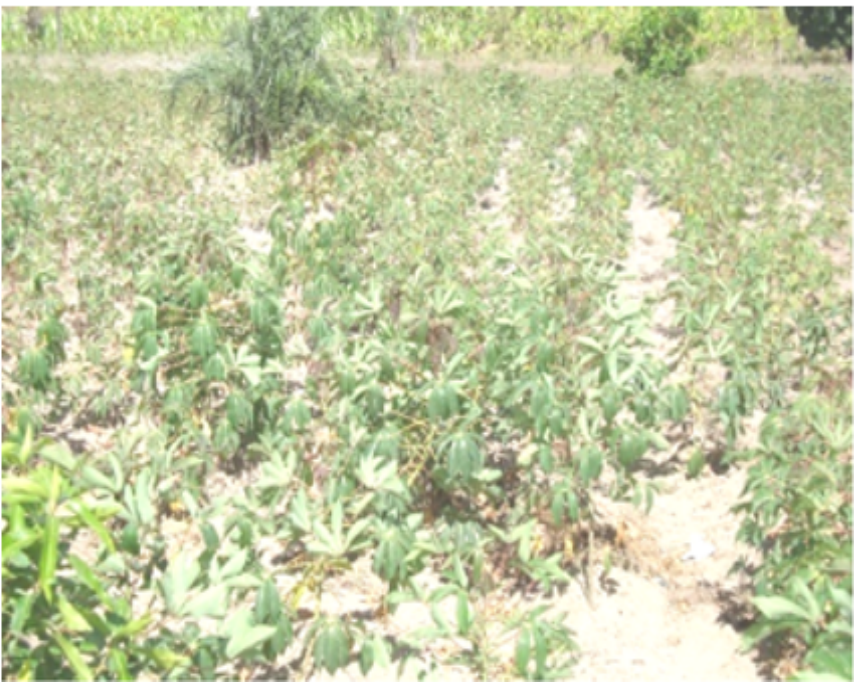

Fonte: Wellington Lira (2018) 
A partir das características gerais dessas comunidades o que mais se pode perceber é a precária condição de vida de suas populações, ficando sujeitas as poucas ações dos agentes governamentais.

Até bem pouco tempo o Governo Brasileiro possuía um hipotético conhecimento sobre a diversidade fundiária do país. Ao incluir os diversos grupos não-camponeses na problemática fundiária, o Governo vai além do tema da redistribuição de terras, envolvendo assim, uma temática centrada nos processos de ocupação e afirmação territorial, os quais remetem, dentro de um marco legal do Estado, as políticas de ordenamento e reconhecimento territorial.

Neste Sentido, é significativo para uma comunidade ter plenos domínios da sua área, uma vez que isto Ihe confere uma condição indispensável para a sua sobrevivência física e cultural.

\section{CONCLUSÃO}

Diante dos resultados apresentados, pode-se evidenciar a relevância do processo de planejamento, identificação e delimitação de territórios quilombolas realizados pela Fundação Cultural Palmares e pelo INCRA, nas comunidades existentes no município de Garanhuns-PE. Uma vez que, o questionamento central desta pesquisa: como o processo de identificação e delimitação de territórios quilombolas pode se relacionar com a questão identitária e a dinâmica socioterritorial? Nos põe a reflexão sobre isto.

Dessa forma, fica evidente que discussões sobre esta nova perspectiva da problemática fundiária nacional, que trata dos grupos não-camponeses, não se encerra aqui, devendo existir outros desdobramentos que possam trazer a luz todos os conflitos e entraves que impeçam uma profunda e equânime reforma agrária no Estado brasileiro. 


\section{REFERÊNCIAS}

AMADO, J. A formação em investigação qualitativa: Notas para a construção de um programa. In: Investigação Qualitativa: Inovação, Dilemas e Desafios. 3. ed. Ludomedia: Lisboa, 2015. pp. 39-68. Disponível em: https://ludomedia.org/a-formacao-em-investigacao-qualitativa-notas-para-a-construcao-de-um-programa/ Acesso em 25 de junho de 2021.

ANDRADE, M. C. A questão do território no Brasil. São Paulo: Hucitec; Recife: IPESPE, 1995.

BOBBIO, N. Estado, Governo, Sociedade: Para uma teoria geral da política. 13. ed. São Paulo: Paz e Terra. 2007.

BONAVIDES. P. Ciência Política. 10.ed. $9^{a}$ tiragem. São Paulo: Malheiros Editores. 2000.

BRADLEY, H. Fractured identities. Cambridge: Polity Press, 1996.

CUCHE, D. A noção de cultura nas ciências sociais. Bauru: Edusc, 1999.

GIL, A.C. Métodos e técnicas de pesquisa social. 5.ed. São Paulo: Atlas, 2007.

GOODE, W. J.; HATT, P. K. Métodos em pesquisa social. São Paulo: Nacional, 1975.

HAESBAERT, R. O mito da desterritorialização: do fim dos territórios a multiterritorialidade. Rio de Janeiro: Bertrand Brasil, 2004.

R. Des-territorialização e identidade: a rede "gaúcha" no Nordeste. Niterói: EdUFF, 1997.

LÜDKE, M.; ANDRÉ, M.E.D.A. Pesquisa em educação: abordagens qualitativas São Paulo: EPU. 2013.

MARCONI, M. D. A.; LAKATOS, E. M. Técnicas de pesquisa: planejamento e execução de pesquisas, amostragens e técnicas de pesquisas, elaboração, análise e interpretação de dados. 7.ed. São Paulo: Atlas, 2010. 
MEDEIROS, S. Bases epistemológicas do positivismo e do materialismo dialético: notas para reflexão. In. Itinerarius Reflectionis vol.6 no 22011 pp 1-16. Disponível em: https://www.revistas.ufg.br/rir/article/view/20360 Acesso em 04 de agosto de 2021.

MOSER, G. Introdução a Psicologia Ambiental:pessoa e ambiente. Campinas, SP: Alinea. 2018.

MUSSI, R.F.F. et al. Pesquisa Quantitativa e/ou qualitativa: distanciamentos, aproximações e possibilidades. Revista Sustinere, Rio de Janeiro, v. 7, n. 7, p. 414-430, jul./dez., 2019. Disponível em: https://www.e-publicacoes.uerj.br/index. php/sustinere/article/view/41193 Acesso em 30 julho de 2021.

RAFFESTIN, C. Por uma geografia do poder. Tradução de Maria Cecília França. São Paulo: Ática, 1993.

SANTOS, M. A natureza do espaço - técnica e tempo - razão e emoção. São Paulo: Hucitec, 1996.

, et al. O papel ativo da geografia: um manifesto. Florianópolis: XII Encontro Nacional de Geógrafos 2000.

, et al. (orgs.) Território: Globalização e fragmentação. São Paulo: Hucitec e ANPUR 1994.

SAQUET, M. A., BRISKIEVICZ, M. Territorialidade e identidade: um patrimônio no desenvolvimento territorial. In.: Caderno Prudentino de Geografia, n³1, vol.1, 2009. p. 03-16. Disponível em: https://revista.fct.unesp.br/index.php/cpg/article/ view/7437. Acesso em: 20 de março de 2021.

SCHNEIDER, D. R. Sartre e a psicologia clínica. Florianópolis: Editora da UFSC. 2011.

SILVA, FJ, ALCÂNTARA, N. Linguagem e pensamento na perspectiva de Vygotsky. IN. Revista Católica vol. 5 n 92013 Disponível em: http://revista.catolicaonline.com.br:81/revistadigital/index.php/revistadacatolica/article/viewFile/700/562 Acesso em 05 de julho de 2021.

SILVEIRA, D.T.; CÓRDOVA, F.P. A pesquisa Científica. In: Métodos de Pesquisa. Porto Alegre: Editora da UFRGS, p. 31-42, 2009. 
VERGARA, S. C. Projetos e relatórios de pesquisa em administração. 3.ed. Rio de Janeiro: Atlas, 2000.

WEEKS, J. The value of difference. In: Identity: community, culture, difference. London: Lawrence \& Wishart, 1990. p. 88-100.

YIN, R. K. Estudo de caso: planejamento e métodos. Porto Alegre: Bookman. 2005. 


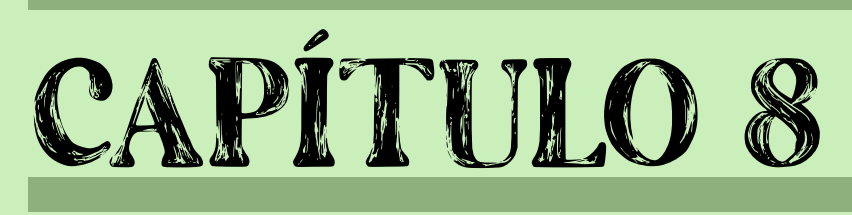

\section{DENDEICULTURA} E TRANSFORMAÇÃO DA PAISAGEM RURAL NA MICRORREGIÃO DE TOMÉ-AÇU

Leonardo de Sousa Santos João Santos Nahum 


\section{INTRODUÇÃO}

A ocupação da Amazônia setentrional tem características próprias, que se diferenciam de outros espaços geográficos, dentro e fora do seu território nacional, sobretudo porque o Estado foi um dos principais vetores que asseguraram à chegada dos atores a esta fronteira do capital natural, fonte colossal de riquezas do solo, do subsolo, dos rios, da fauna e flora, como esclarece Becker (1997) e Becker (2009).

O Estado e suas políticas públicas, associados à interesses diversos e externos, desenvolveram distintas fases da reprodução do capital, configuração territorial, reorganização espacial e dinâmicas sociais ao longo da história da Amazônia, sobretudo pela busca do crescimento econômico, por meio do aproveitamento da potencialidade florestal, da pecuária, da agricultura, mineração, e hoje, em algumas regiões, pelo agronegócio da palma de óleo (MEIRELLES FILHO, 1986; HOMMA; FURLAN JÚNIOR, 2011).

A Microrregião de Tomé Açu (MRGTA), assim como outros lugares da Amazônia paraense, recebeu desvelo do Estado, os quais impulsionaram diversos eventos (ciclos econômicos) que foram importantes construtores de novos mosaicos da paisagem, testemunhados pelas transformações nas formas, estruturas e funcionalidade dos objetos do lugar, a exemplo da derrubada das florestas, construções de estradas, surgimentos dos núcleos de ocupações, até a chegada da dendeicultura.

Nesse sentido, a MRGTA encontra-se bem diferente dos tempos passados, decorrente da lógica do dendê, que se transforma num evento "vivo", que pode ser percebido e investigado qualitativamente e quantitativamente, por meio dos milhares de talhões de cultivo dessa oleaginosa. Assim, objetivo é analisar as transformações da paisagem rural da MRGTA, proveniente da evolução da palma de óleo, ao longo de trinta anos, incentivados por ações e políticas de expansão da palma de óleo na Amazônia. 


\section{MATERIAIS E MÉTODOS}

\section{Área em estudo}

A área geográfica deste estudo é composta pelos municípios do Moju, Acará, Tailândia, Tomé-Açu e Concórdia do Pará, que juntos correspondem a Microrregião de Tomé-Açu (MRGTA), pertencente à mesorregião do nordeste paraense, com uma área total de 23.704,079 km² (IBGE, 2010), conforme Figura 1.

Figura 1 - Microrregião de Tomé-Açu (MRGTA).

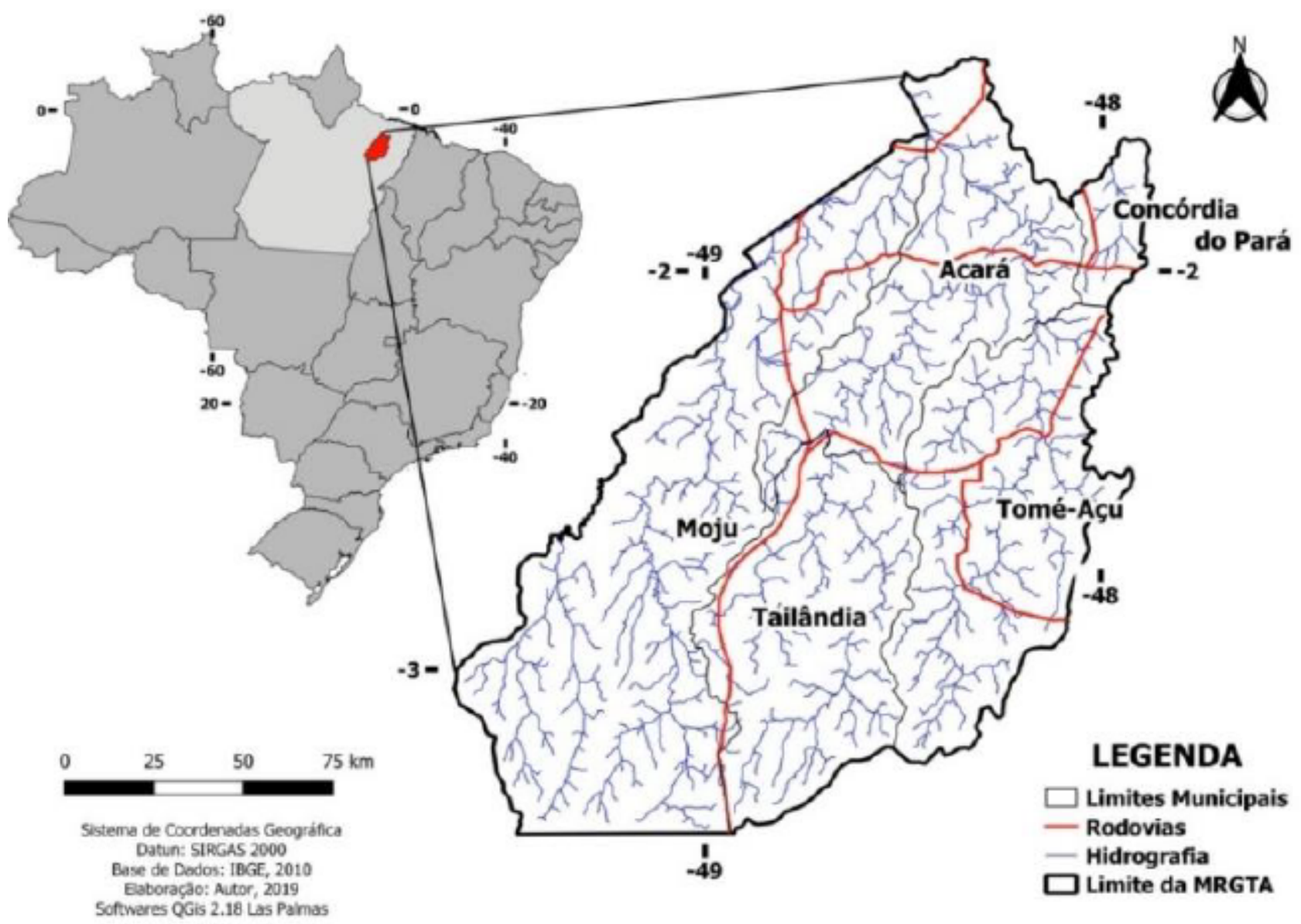

Fonte: Autor (2019).

\section{Procedimentos metodológicos}

Foram adotados dois procedimentos metodológicos complementares que são: 


\section{Metodologia analítica:}

Na primeira etapa foi realizado uma pesquisa bibliográfica qualitativa descritiva, sobre o tema, disponíveis em materiais publicados em livros, artigos, dissertações, teses, boletins e relatórios técnicos e resumos de eventos com os temas correlatos ao objetivo proposto. Ainda nesta fase, realizou-se um estudo da formação da dendeicultura na Amazônia, para acompanhar a trajetória da palma de óleo na região norte, em especial na Microrregião de Tomé-Açu (MRGTA).

\section{Metodologia operacional:}

A metodologia utilizada na análise envolveu cinco etapas: Na primeira fase, construiu-se a base de dados para este estudo por meio de imagens orbitais do satélite Landsat para anos de 1988, 1995, 2004, 2010 e 2018, fundamentada numa periodização dos marcos históricos da trajetória desta cultivar na Amazônia e em especial na MRGTA.

Na segunda fase, efetuou-se a interpretação visual e o comportamento espectral das culturas do dendê nas imagens Landsat, com base nos elementos de localização geográfica, tamanho, padrão, forma, textura, cor, tonalidade, sombra e valores de reflectância de superfície terrestre.

Na terceira etapa, realizou-se a classificação supervisionada para extração das áreas de cultivo de dendê na MRGTA entre os anos de 1988 a 2018. $\mathrm{Na}$ quarta fase, com arquivos vetoriais gerados, fez-se o mapeamento das áreas de cultivo, onde foi possível analisar a variação espaço temporal entre as diferentes classes de uso mapeadas por meio do Sistema de Informação Geográfica Q. Gis. Ainda nesta fase, fez-se trabalho de campo, para o reconhecimento das características das unidades de paisagem da MRGTA, através da correlação das classes temáticas nas imagens dos sensores orbitais. Ainda no campo definiram-se parâmetros relacionados ao histórico de uso de cobertura da terra e cultivo dos dendezeiros.

$\mathrm{Na}$ quinta fase, contabilizou-se as alterações na paisagem pela quantificação dos dados na calculadora digital do SIG/Gis e representados em tabela. A 
tolerância, a acuracidade e a exatidão dos dados, assim como, a precisão espacial requerida para a seleção das feições das áreas de cultivo de dendê, foi de 90,3\% e o índice de Kappa de 0,85, sendo satisfatório pelas amostras utilizadas e ao resultado que se pretende alcançar.

\section{FORMAÇÃO DA DENDEICULTURA NA AMAZÔNIA PARAENSE}

A formação da dendeicultura paraense corresponde aos processos que têm por fundamento empírico o cultivo do dendezeiro impulsionado e amparado por políticas de Estado, as quais criaram condições jurídicas e institucionais para o avanço do cultivo do dendezeiro com racionalidades empresariais no meio rural da Amazônia, em especial da microrregião de Tomé-Açu.

Entende-se por formação da dendeicultura, o conjunto de vertentes cronológicas que viabilizam a organização, no tempo e no espaço, da lavra do dendezeiro e, por conseguinte, da dendeicultura enquanto forma do agronegócio das commodities no meio rural, em especial no território amazônico. De forma geral, a constituição da dendeicultura é uma reconstituição das ações e dos processos de organização espacial da dendeicultura, sendo um pré-requisito para as análises e proposições do estudo da transformação da paisagem rural proveniente dessa agricultura empresarial.

Longe de contemplar todos os fatos e sem a pretensão de esgotar o tema, interpreta-se pelas vertentes visíveis e inteligíveis dos eventos inter-relacionados que contribuíram para expansão do dendezais na Amazônia, que a cultura do cultivo da palma de óleo (dendê), foi pensado, criado e organizado por meio de investimentos públicos e renúncias fiscais, os quais modificaram a configuração espacial, e as relações sociais, bem como a paisagem aonde se estabeleceu (NAHUM; DOS SANTOS, 2013).

A formação da dendeicultura na Amazônia Paraense, mesmo que distante de uma geografia do tempo, possibilita acompanhar a trajetória dos processos, pontuando marcos singulares que desencadearam a reverberação do cultivo do 
dendezeiro. O processo de reconstituição da origem, consolidação e expansão da dendeicultura na Amazônia paraense, é contada por uma vasta literatura, que vai desde o período da chegada dos dendezeiros, passando pelo surgimento das cooperativas e empresas pioneiras, bem como dos programas governamentais que desencadearam a expansão e consolidação no território paraense.

A formação da dendeicultura no norte do Brasil, é caracterizada por uma linha evolutiva da sua historicidade, que tem ajudado a entender sobre sua distribuição na Amazônia, predominantemente na região em análise, até seu período atual grifado pelos projetos de integração do agricultor rural na produção do óleo de dendê, tendo como discurso o desenvolvimento econômico sustentável, social e ambiental. Portanto, a cada período de desenvolvimento dos dendezais na Amazônia, houveram vertentes que possibilitaram sua expansão. As vertentes ou fases se misturam uma com as outras, e apesar de possuírem datas específicas, seus efeitos, somados a ligações exteriores, foram potencializadas interferindo na paisagem rural, e com transferência de mazelas e problemas para os períodos seguintes.

Hoje, a Microrregião de Tomé-Açu é marcada por extensas monoculturas de dendê (Figura 2), que produziram mudanças no mosaico da paisagem e na vida do camponês, nascendo a fronteira do biodiesel, que pode ser inventariada (quantificada) por técnicas consagradas de extração de informações de satélites artificiais que fotografam a terra de forma regular. Na Figura 2, visualiza-se uma extensa área de cultivo de dendê ( $2^{\circ} 38^{\prime} 28.10^{\prime \prime S}$; 4848'46.08”O), entre os municípios de Moju e Tailândia, que foram plantados, sob o projeto agroindustrial, com o pretexto da produção do biodiesel. 
Figura 2 - Dendezeiros ao longo da PA 252 e 475 (Moju - Tailândia)

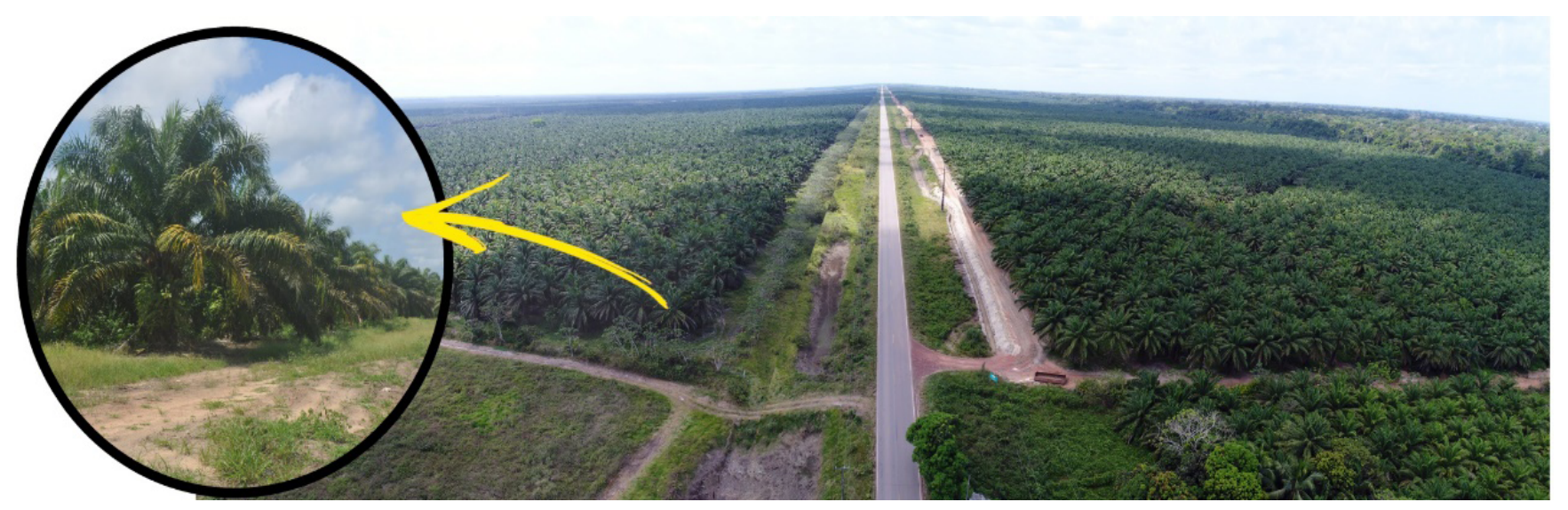

Fonte: Trabalho de campo (2019).

No cenário brasileiro, a Amazônia passa a ser recomendada para produção de óleos vegetais e seus derivados, pelo ponto de vista edafoclimático, acesso a mão-de-obra e ao mercado consumidor por meio de portos e rodovias, dentre outras vantagens importantes para a implantação de qualquer empreendimento econômico, como esclarece Nahum (2014, apud Cruz, 2006). Neste processo produtivo do dendezeiro, o Pará conta com empresas de diversos portes, além de áreas de cultivos que ressignificaram a categoria do agricultor familiar, tornando-o um empreendedor rural.

\section{PAISAGENS RURAIS DA MICRORREGIÃO DE TOMÉ-AÇU}

A interpretação da paisagem é fundamental para a análise de elementos que estão inter-relacionados e que buscam retratar uma dinâmica natural instável, que reagem com as atividades humanas, como explicam Pissinati e Archela (2009). Neste contexto, Bertrand (1971), traz à luz uma metodologia capaz de lidar com parte da complexidade indissociável da paisagem que está em perpétua evolução.

A análise da paisagem, sob a ótica bertrandiana, implica em ler a complexidade existente no dinamismo das paisagens para além das aparências das coisas, como um cenário ou vitrine, mas considerando as Unidades de Paisa- 
A QUESTÃO AGRÁRIA NO BRASIL: CAMPESINATO, AGRICULTURA FAMILIAR E AGRONEGÓCIO

gens (UPs) como entidades globais, composta por sociedade e natureza (BERTRAND, 1971 apud PISSINATI; ARCHELA, 2009).

Bertrand (1971), através das UPS, supera a ruptura entre sociedade e natureza no espaço geográfico e suas várias formas de relações construídas entre coletividade e ambiente (DE BRITTO; FERREIRA, 2011). A totalidade das formas de criações, reproduções e transformações das estruturas das paisagens é dado pela análise dos elementos físicos, biológicos e antrópicos, que reajam dialeticamente, uns com os outros (BERTRAND; BERTRAND, 2007).

Contudo, é necessário determinar uma porção do espaço geográfico para interpretação das UPs, pois o espaço geográfico é complexo, dinâmico e heterogêneo, pois é integrado pelos sistemas naturais, culturais e sociais, e ainda é reflexo da lógica local e mundial. Na prática, o estudo da paisagem rural, requer representações cartográficas em escala de apreensão adequada a cada nível hierárquico de classificação da paisagem, podendo variar de centenas de quilômetros quadrados, passando por metros quadrados, até centímetros quadrados.

Nessa proporcionalidade, Bertrand (1971) subdivide espaço em categorias espaciais, de componentes relativamente homogêneos nomeados de Mosaicos de Unidades Homogêneas (MUH), cujas estruturas e dinâmicas resultam das interações entre os potenciais ecológicos, biológicos e ações antrópicas. Os $\mathrm{MUH}$, materializam o conceito de escala de investigação do sistema tripolar bertrandiano, por meio dos eixos horizontal e vertical, destacando as diferenciações espaciais dos elementos naturais subdivididos como unidade de análise de UPs, as quais mais se aproximam da realidade geográfica e as que são mais modificadas pelo homem ao longo da história. Os Mosaicos MUH e suas extensões territoriais e limites, identificáveis em eixos, podem dar o mínimo de organização espacial de fenômenos corológicos sobre uma dada área que na maioria das vezes são construídas ou destruídas pela ação humana, sob a égide do grande capital.

Como Mosaico de Unidades Homogêneas (MUH), o uso e cobertura da terra da Microrregião de Tomé-Açu (MRGTA) que mais se destaca é a floresta primária, a pastagem e o cultivo do dendezeiro, em razão de suas áreas territoriais. 
Ou seja, a cada ano a floresta foi convertida em vegetação secundária ou solo exposto, após o uso temporário da terra, para exploração madeireira, pastagem, agricultura, hoje grande parcela da MRGTAé tomado pelo agronegócio do dendê.

\section{RESULTADO E DISCUSSÃO}

Com a interpretação histórica do processo de ocupação da dendeicultura na Microrregião de Tomé-Açu (MRGTA), a história revela que a chegada, implantação e consolidação do dendê, tem sua gênese num importante projeto do Estado de ocupação e de adequação ambiental deste território, por meio de políticas de "desmatamento zero" com a adição "sustentável" de uma nova MUH, socialmente aceita, em razão da inclusão do agricultor na cadeia de produção do dendezeiro.

Com a análise por período, entende-se que as mudanças na paisagem rural do nordeste paraense são oriundas, primeiro da exploração seletiva de madeiras, bem como implantação dos projetos pecuários, os quais provocaram a redução no MUH de floresta primária ao longo de mais de 30 anos. No caso da evolução da MUH do dendê, o discurso está associado ao progresso econômica e social do espaço, refletindo em uma dinâmica de plantio de milhares de $\mathrm{km}^{2}$ de dendezais, caracterizando a paisagem rural-local da MRGTA, associada a elementos advindos de uma lógica global do agronegócio.

Assim, entre 1988 a 1995 a perda de cobertura vegetal esteve diretamente ligada à agropecuária extensiva (TEIXEIRA JÚNIOR, 2017, p. 32). Só a pastagem entre 1988 a 1995 (7 anos) nessa microrregião cresceu 14,4\%. As plantações de dendezeiros em 1988 ocupavam uma área de 220,45 km², passando para 284,17 km² em 1995, crescendo em torno de 22,4\% em 7 anos. Contudo, é entre 1988 a 2004, que ocorre a intensa exploração seletiva da madeira, bem como, a implantação dos projetos pecuários, que vão gerar a crise do setor madeireiro, decorrente da exploração/degradação, provocado pelo fogo/extração da madeira/lavoura/carvoaria/pasto, o que vai desencadear uma intensa e extensa mudança na MUH de floresta. 
A QUESTÃO AGRÁRIA NO BRASIL: CAMPESINATO, AGRICULTURA FAMILIAR E AGRONEGÓCIO

Entre 1995 a 2004, na MRGTA, houve um aumento nas MUH de pastagens no sentido sul e leste da área em análise, principalmente nos municípios de Tailândia e Tomé-Açu (Figura 2). Neste período, as MUH de dendezais cresceram $73,9 \%$ (7 anos), passando a ocupar um espaço de mais de $244,96 \mathrm{~km}^{2}$ (Tabela 1) na MRGTA, o que equivale a 34 campos de futebol, aonde foram plantadas mais de 2 milhões de dendezeiros. Com os dados das imagens orbitais, a MUH de vegetação de floresta foi suprimida, entre 1995 a 2004, em mais de 200\%, e as MUH de pastagens evoluíram em 39\% (Tabela 1).

Ainda entre 1995 a 2004, as transformações e as mudanças na paisagem na MRGTA, também são decorrentes dos processos de ocupações espontâneas ou dirigidas incentivadas pelo Estado, que provocou a abertura dos ramais, vicinais, ruas marginais e rodovias para os novos núcleos de povoamentos (BARROS; VERÍSSIMO, 1996, p.12). Além disso, o lançamento de programas governamentais, como o de Incentivo à Produção de Biodiesel (Pará Biodiesel), foi responsável pelo aumento de $532,48 \mathrm{~km}^{2}$ nas $\mathrm{MUH}$ de cultivo do dendezeiro, perfazendo uma expansão de 54\% entre 1995 e 2004.

No final desse tempo, o Programa Nacional de Produção e Uso de Biodiesel (PNPB), garanti maior ousadia das grandes empresas dendeicultura para o crescimento das MUH de dendê da Região Norte, em especial da MRGTA, lastreado pela inclusão social e econômica, da agricultura familiar (CÉSAR; BATALHA, 2010).

Entre 2004 a 2010 houve uma crise do setor madeireiro da Amazônia, que teve como marco o ano de 2008, quando foi desencadeada a "Operação Arco de Fogo", que fechou uma série de madeireiras e carvoarias na região (VAN DEURSEN VARGA, 2017, p.230), sobre tudo no município de Tailândia (ARAÚJO, 2020; ARAÚJO, 2017; TEIXEIRA JÚNIOR, 2017). A expansão das MUH de dendê neste período, inscreve-se no movimento do controle do desmatamento, através da produção de biocombustíveis, iniciada em 2004, em razão da meta nacional de adição de 5\% de biodiesel ao petrodiesel, a ser atingida até 2013. 
De forma geral, entre 2004 a 2010, a MUH de vegetação nativa na MRGTA, cresceu $56,6 \%$, a MUH de pastagem evoluiu para 32,9\% e o MUH de dendezal acendeu apenas $36,6 \%$. A evolução na $\mathrm{MUH}$ de vegetação e o crescimento da MUH do cultivo do dendezeiro retrata o primeiro resultado do programa do desmatamento zero na região Amazônica, por meio da iniciativa de ocupação das MUH de pastagem por MUH de palma de óleo. Ou seja, o governo estadual e federal inicia em 2005 um trabalho de incentivo a ocupação da terra degradada por dendezeiros, o que vai ecoar mais uma vez no crescimento médio de $4,3 \%$ do cultivo, com relação ao período anterior (1995 a 2004), conforme Tabela 1.

Entre 2010 e 2018, inicia-se um período de especulação imobiliária na MRGTA, em razão dos grandes investimentos privados para expansão da produção de óleo de palma, após os lançamentos do Programa Nacional de Produção Sustentável de Palma de Óleo (PPSPO) e do Programa Nacional de Fortalecimento da Agricultura Familiar (Pronaf - ECO), ocasionando mudanças nos "modus operandi" de exploração, compra e venda de terras situadas na faixa preferencial de $55.000 \mathrm{~km}^{2}$, com condições edafoclimáticas para a implantação da cultura do dendezeiro em harmonia com a biodiversidade (RAMALHO FILHO; MOTTA, 2010). É neste intervalo de tempo que as MUH de dendezais crescem 63,3\% em 8 anos. A taxa de crescimento anual das áreas de cultivo do dendê foi de 7,9\% ao ano, equivalendo a uma expansão de mais de $181,42 \mathrm{~km}^{2}$ por ano (Tabela 1), alicerçados pelos Programas PPSPO e Pronaf - ECO.

Tabela 1 - Evolução dos principais usos e coberturas da Terra da MRGTA.

\begin{tabular}{c|c|c|c}
\hline $\begin{array}{c}\text { Uso e Cobertura } \\
\text { da Terra }\end{array}$ & Vegetação & $\begin{array}{c}\text { Solo Exposto / } \\
\text { Pastagem }\end{array}$ & Dendezais \\
\hline $\mathbf{1 9 8 8}$ & $20.795,82$ & $2.374,11$ & 220,45 \\
\hline$(\mathbf{1 9 9 5 - 1 9 8 8 )}$ & $-531,47$ & 400,27 & 63,72 \\
\hline$\%$ & $-2,6$ & 14,4 & 22,4 \\
\hline $\mathbf{1 9 9 5}$ & $20.264,35$ & $2.774,38$ & 284,17 \\
\hline$(\mathbf{2 0 0 4}-\mathbf{1 9 9 5 )}$ & $-13.724,92$ & $1.770,34$ & 248,31 \\
\hline
\end{tabular}


A QUESTÃO AGRÁRIA NO BRASIL: CAMPESINATO, AGRICULTURA FAMILIAR E AGRONEGÓCIO

\begin{tabular}{c|c|c|c}
\hline $\boldsymbol{\%}$ & $-209,9$ & 39 & 46,6 \\
\hline $\mathbf{2 0 0 4}$ & $6.539,43$ & $4.544,72$ & 532,48 \\
\hline $\mathbf{( 2 0 1 0 - 2 0 0 4 )}$ & $8.535,91$ & $2.225,49$ & 307,82 \\
\hline $\boldsymbol{2 0 1 0}$ & 56,6 & 32,9 & 36,6 \\
\hline $\mathbf{2 0 1 0}$ & $15.075,34$ & $6.770,21$ & 840,3 \\
\hline $\mathbf{( 2 0 1 8 - 2 0 1 0 )}$ & $-607,46$ & $-2.387,02$ & $1.451,36$ \\
\hline $\mathbf{2 0 1 8}$ & $-4,2$ & $-54,5$ & 63,3 \\
\hline & $14.467,88$ & $4.383,19$ & $2.291,66$ \\
\hline
\end{tabular}

Legenda: \% - Taxa de crescimento.

Fonte: Geoprocessado pelo autor (2019).

Com a quantificação das MUH de dendê, contabilizou-se que a MRGTA possuía 152 polígonos de área de cultivo em 2010, e após 8 anos passou a ter 808 polígonos de dendezais, totalizando respectivamente $840,99 \mathrm{~km}^{2}$ e 22.96,06 $\mathrm{km}^{2}$ em 2018. E é neste período, que temos as MUH de pasto dando lugar as MUH de dendê, sendo esta expansão, reconhecida pelo Estado como uma excelente alternativa para a recuperação do desequilíbrio ambiental na Amazônia, inaugurando-se um novo ciclo de crescimento econômico, com a justificativa de gerar trabalho, emprego e renda com sustentabilidade (NAHUM E DOS SANTOS, 2018; CRUZ; DE FARIAS, 2018).

Com os dados analisado, percebe-se que entre 2004 a 2018, que as $\mathrm{MUH}$ de dendê começam a desenhar uma nova paisagem na MRGTA, sobretudo incentivado por condições políticas e programas de expansão do cultivo (PNPB e PPSPO), em razão do mercado internacional de commodities e do combate ao "desmatamento zero". Neste cenário, a Dendeicultura aparece como um importante projeto de adequação ambiental e de produção sustentável a partir de 2004. (DE SOUSA, 2019).

Dizemos até certo ponto que, a paisagem rural dessa microrregião está bem diferente dos tempos passados, resultado da contribuição do Estado, inicialmente para os projetos de ocupação do Brasil e, por conseguinte, para o desen- 
volvimento econômico a qualquer custo, o que vai provocar as transformações da paisagem, no início em função da exploração dos recursos naturais e hoje advindo do agronegócio da dendeicultura, que têm avançado por saltos através de décadas, conduzida pela ação do Estado e de suas políticas públicas, bem como pelas corporações gigantescas ou firmas transnacionais.

Inicialmente, os MUH de dendê foram cultivados em latifúndios improdutivos ou subaproveitáveis degradados, criado pela pecuária, durante a época da abertura das vicinais, estradas e rodovias. Durante seu período de expansão o MUH de dendê, avançaram sobre as MUH de vegetação, e nos dias atuais, instalam-se sobre os minifúndios explorados por proprietários e sua família, tanto na área rural e urbana da MRGTA, reflexo do conjunto de financiamento do capital nacional e isenções fiscais para incentivar as empresas dendeicultoras.

Portanto, o cenário natural da MRGTA foi submetido a uma intensa transformação, que concebeu um mosaico com formas e cores, neste caso, proveniente da combinação singular de políticas públicas que desencadearam mudanças no cenário do passado ao futuro, considerando o uso da terra.

Na Figura 3, ilustra-se a transformação da paisagem da MRGTA, em razão das constantes modificações das $\mathrm{MUH}$, que viveram nesta região, momentos mais intensos que outros, geralmente após o lançamento de políticas e programas que subsidiam e legitimam o poder público-privado a realizarem a concentração e centralização de terras por meio da aquisição de imóveis, reforçando continuamente a estrutura agrária desigual na Amazônia, e hoje em razão do mercado internacional de commodities do dendê (DA SILVA, 2009; SANTOS NAHUM; DOS SANTOS, 2018). 
Figura 3 - Evolução e distribuição do uso e cobertura da terra na MRGTA de 1988 a 2018.

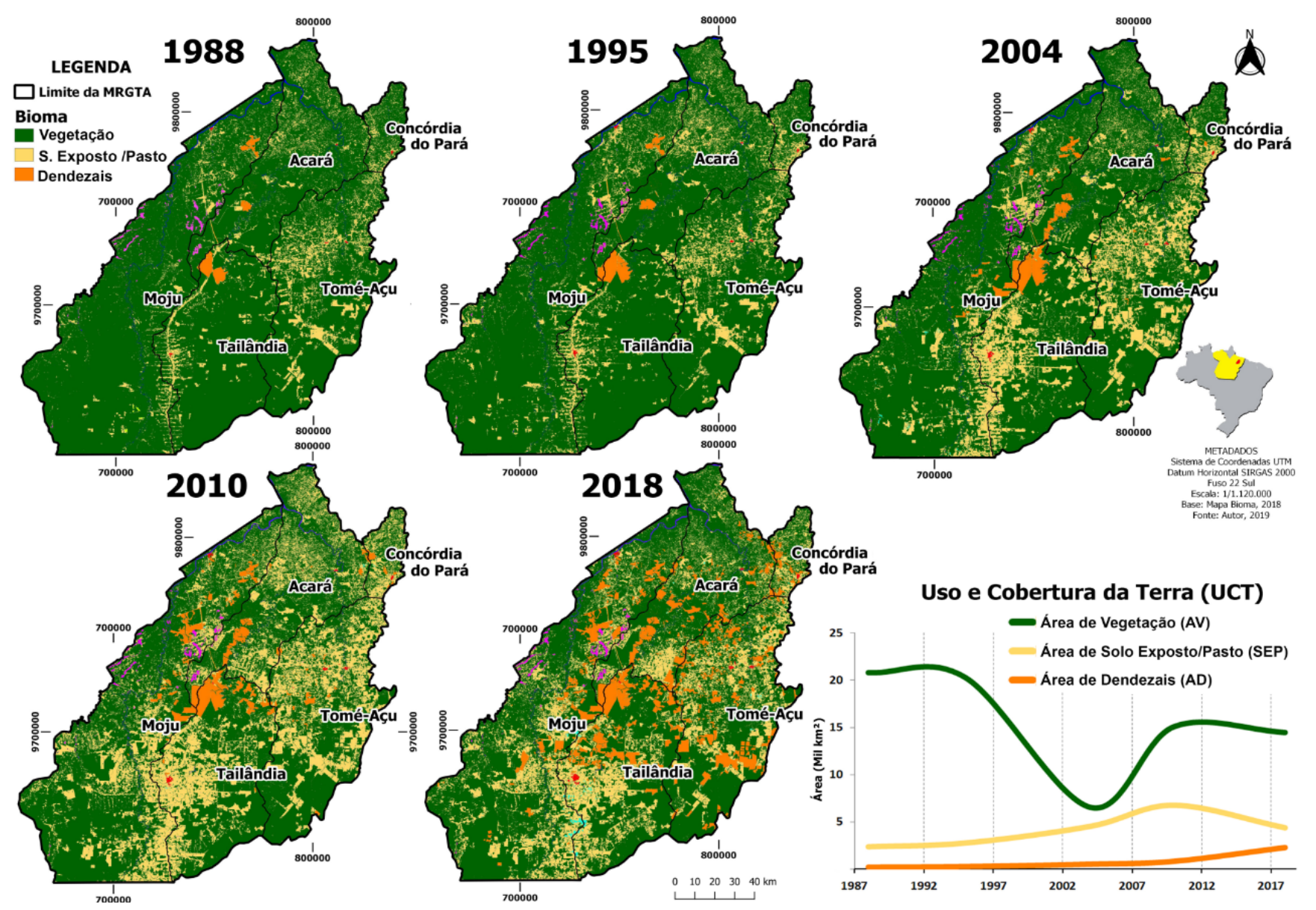

Fonte: MapBioma e Geoprocessado pelo Autor (2019)

É importante destacar, que com a expansão dos dendezais tem-se o aumento da MUH da cobertura vegetal da região, contudo mesmo sendo uma espécie fotossintetizante, trata-se de uma paisagem exótica, com baixa biodiversidade, e com pouca representatividade de aves e mamíferos, muito diferente do bioma florestal, devendo ser destacada como um mosaico homogêneo distinto, pois é única à paisagem proveniente dessa cultivar.

Hoje na MRGTA, presencia-se a modelagem e remodelagem da paisagem, como consequências das ações do Estado, que igualmente vai garantir a concentração e a exploração da terra pelo modelo agroexportador de grande escala, que tem desestimulado as atividades econômicas subsidiárias e complementares, como a produção de alimentos, para atender os interesses da economia capitalista (DOS SANTOS; NAHUM; DOS SANTOS, 2018). Assim, as MUH de 
agricultura familiar, até então isoladas, estão deixando de produzir a policultura e o excedente de alimentos.

\section{CONSIDERAÇÕES FINAIS}

Com resultado, revela-se que ocorreu um intenso processo de mudanças de paisagens natural da Microrregião de Tomé-Açu. Os mosaicos de unidades homogêneas, em especial de Florestas, ano após ano, deu lugar ao dendê, decorrentes das ações, planos e programas para o desenvolvimento econômico do lugar a qualquer custo, o que possibilitou as alterações no mosaico da paisagem da microrregião de Tomé-Açu,

Percebe-se que a formação da paisagem da microrregião de Tomé-Açu, caminha pari e passu com a reorganização e a configuração espacial do território do agronegócio, agrupando intencionalidades diversas, que introduzem nos lugares onde aportam, novas temporalidades e espacialidades segundo a lógica do mercado mundial, ou decorrente de uma lei, de uma portaria e/ou decretos, os quais não poupam esforços para consolidar seus lucros. As manifestações das relações entre políticas e dendeicultura deram o poder e as condições para chegada do mosaico de unidades homogêneas do dendê, por meio do agronegócio.

Alcança-se que na área em estudo, há uma relação entre política e dendeicultura, capaz de produzir mudanças no mosaico da paisagem rural, disfarçado de estratégia de preservação ambiental e redução do desmatamento, pois as antigas fazendas e áreas degradadas, foram sendo ocupadas pela palma de óleo, representando uma modificação no mosaico de unidades homogêneas da cobertura vegetal, mas que não corresponde à volta do equilíbrio natural dos elementos que "ainda" acham-se integrados.

Sublinha-se que a paisagem da microrregião de Tomé-Açu é uma vitrine dos planos e políticas públicas, que tem o poder de produzir alterações nas unidades de paisagens, e por conseguinte no meio ambiente e na vida dos agricul- 
tores familiares. Portanto, seu cenário não pode ser considerado apenas a aparência das coisas, mas receptáculo da história econômica associada ao capital internacional.

A lógica de produção do espaço da microrregião de Tomé-Açu, por meio da evolução das unidades de paisagens dos talhões de dendezeiros, revela como é essencial o entendimento dos padrões espaciais e as relações dialéticas entre processos históricos do uso transitório da terra por meio de políticas econômicas, que muitas das vezes estão atrelados ao discurso do desenvolvimento territorial, geração de trabalho, emprego, renda e inclusão social. Os resultados deste trabalho, representam um olhar sobre a expansão da dendeicultura e as transformações na paisagem, desencadeados por planos, programas e políticas públicas que deram as condições normativas, financeiras e espaciais, capazes de promover uma dinâmica no mosaico da paisagem.

\section{REFERENCIAS}

ARAÚJO, C. T. D. Mudanças na paisagem da região de Tailândia, estado do Pará, entre os anos de 1985 a 2015. 2017. xvii, 146 f., il. Dissertação (Mestrado em Ciências Florestais) - Universidade de Brasília, Brasília, 2017. Disponível em: <https://repositorio.unb.br/handle/10482/23648>. Acesso em: 15 ago. 2019.

ARAÚJO, M. J. Fundamentos de agronegócios. Editora Atlas SA, 2000.

BARROS, A. C.; VERRÍSIMO, A. Expansão da atividade madeireira na Amazônia: Impactos e perspectivas para o desenvolvimento do setor florestal no Pará. $1^{\mathrm{a}}$ edição, Belém: Imazon, 1996.

BARROS, A. C.; VERRÍSIMO, A. Expansão da atividade madeireira na Amazônia: Impactos e perspectivas para o desenvolvimento do setor florestal no Pará. $1^{\text {a }}$ edição, Belém: Imazon, 1996.

BECKER, B. Amazônia. São Paulo: Ática, 1997.

BECKER, B. K. Recuperação de áreas desflorestadas da Amazônia: será pertinente o cultivo da palma de óleo (Dendê)?. Confins. Revue franco-brésilienne de géographie/Revista franco-brasilera de geografia, n. 10, 2009. Disponível em:<https://journals.openedition.org/confins/6609> Acesso em: 24 ago. 2019. 
BERTRAND, G., BERTRAND, C. Uma geografia transversal e de travessias: o meio ambiente através dos territórios e das temporalidades. Maringá: Massoni, $p$. 290-291, 2007. Disponível em:< https://periodicos.ufrn.br/revistadoregne/article/ view/15244 >. Acesso em: 15 out. 2019.

CÉSAR, A. da S.; BATALHA, M. O. Biodiesel in Brazil: history and relevant policies. Journal of Agricultural Research, v.5, p.1147-1153. 2010. Disponível em: <https://www.researchgate.net/profile/Aldara_Cesar/publication/311680197_Biodiesel_no_Brasil_Uma_Perspectiva_Historica/links/58a48d05a6fdcc0e075a3b0d/ Biodiesel-no-Brasil-Uma-Perspectiva-Historica.pdf>. Acesso em: 12 ago. 2019.

CRUZ, R. H. R. R; DE FARIAS, A. L. A. Impactos Socioambientais de Produção de Palma de dendê na Amazônia Paraense: Uso de Agrotóxicos. Revista GeoAmazônia, v. 5, n. 10, p. 86-109, 2018. Disponível em: <http://www.geoamazonia.net/index.php/revista/article/view/153>. Acesso em: 12 set. 2019.

CRUZ, B. E. V. Territorialização e organização espacial do grupo Agropalma. 2006. 2006. Tese de Doutorado. Dissertação (Mestrado em Geografia)-Programa de Pós-graduação em Geografia, Universidade Federal do Pará, Belém. Disponível em: <http://ppgeo.propesp.ufpa.br/ARQUIVOS/dissertacoes/2004/ BENEDITO\%20ELY\%20VALENTE\%20DA\%20CRUZ\%20.pdf>. Acesso em: 12 out. 2019.

DA SILVA, C. N. Caminhos e Lugares da Amazônia. Clube de Autores, 2009.

DE BRITTO, M. C., FERREIRA, C. C. M. Paisagem e as diferentes abordagens geográficas. Revista de Geografia-PPGEO-UFJF, v. 1, n. 2, 2011. Disponível em:< https://periodicos.ufjf.br/index.php/geografia/article/view/17890>. Acesso em: 10 set. 2019 .

DE SOUSA, C. F. M. Projetos de desenvolvimento para a Amazônia e a expansão da dendeicultura. Papers do NAEA, v. 28, n. 1, 2019. Disponível em:< https://periodicos.ufpa.br/index.php/pnaea/article/view/7595>. Acesso em: 10 ago. 2019.

HOMMA, A. K. O.; FURLAN JÚNIOR, J. Desenvolvimento da dendeicultura na Amazônia: cronologia. In: MÜLLER, A. A.; FURLAN JÚNIOR, J. Agronegócio do dendê: uma alternativa social, econômica e ambiental para o desenvolvimento sustentável da Amazônia. Belém, PA: Embrapa Amazônia Oriental, 2011. p. 193207. 
MEIRELLES FILHO, J. Amazônia: o que fazer por ela?. São Paulo, Companhia Editora Nacional, 1986.

NAHUM, J. S. Dendeicultura de Energia e Agricultura Familiar na Amazônia Paraense: A Microrregião de Tomé-Açu. Revista Terceira Margem. v. 1, 2013. Disponível em: <http://www. revistaterceiramargem. com/index. php/terceiramargem/index>. Acesso em: 8 abr. 2017.

NAHUM, J. S.; DOS SANTOS, C. B. Agricultura familiar e dendeicultura no município de Moju, na Amazônia paraense. Cuadernos de Geografía: Revista Colombiana de Geografía, v. 27, n. 1, p. 50-66, 2018. Disponível em:<https://www. redalyc.org/jatsRepo/2818/281854495004/html/index.html>. Acesso em: 9 set. 2019.

PISSINATI, M. C., ARCHELA, R. S., Geossistema território e paisagem-método de estudo da paisagem rural sob a ótica bertrandiana. Geografia, v. 18, n. 1, p. 5-31, 2009. Disponível em:< https://www.uel.br/revistas/uel/index.php/geografia/ article/view/2445 >. Acesso em: 24 ago. 2019.

RAMALHO FILHO, A.; DA MOTTA, P.; FREITAS, P.; TEIXEIRA, W. Zoneamento agroecológico, produção e manejo para a cultura da palma de óleo na Amazônia. Rio de Janeiro: Embrapa Solos, 2010. Disponível em: <http://www. abrapalma.org/pt/wp-content/uploads/2015/01/ABRAPALMA-Tudo-Sobre-Palma.pdf>. Acesso em: 22 out. 2017.

TEXEIRA JÚNIOR, T. Fazendo as pazes com a natureza? Estudo sobre a implantação do Projeto "Município Verde" em Paragominas - PA. 1. ed. Curitiba: Editora Prisma, 2017. 


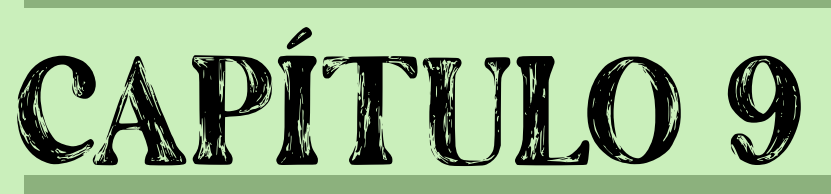

\section{A CESTA AGROECOLÓGICA CAMPO CIDADE (CURITIBA/PR) E A CONSTRUÇÃO DE TERRITÓRIOS AGROECOLÓGICOS 1}

Nathalie Vieira Lucion

1 Trabalho apresentado e publicado em Anais do III Congresso Internacional de Economia Solidária e Desenvolvimento Local: colhendo idéias para adiar o fim do mundo, 24 a 26 de maio de 2021, Feira de Santana / Incubadora de Iniciativas da Economia Popular e Solidária da UEFS.- Feira de Santana:UEFS, 2021. 


\section{INTRODUÇÃO}

Consumidores da cidade, preocupados com seus hábitos de consumo cotidianos, têm optado por alimentos alternativos àqueles ligados à agricultura convencional. Opondo-se aos modos de produção, distribuição e comercialização feitos de forma oligopolizada, desigual e que impactam negativamente o meio ambiente, muitos citadinos veem na Agroecologia uma resposta às suas preocupações com uma alimentação saudável e produzida de forma justa. Sendo uma ciência e movimento político, a Agroecologia têm ocupado muitos espaços de reflexão e discussão, principalmente em relação à produção e consumo, pensada no campo e na cidade.

Dessa forma, a busca por reconhecer como a Agroecologia está mais presente no campo e na cidade através de circuitos de comercialização baseados na economia solidária, constitui-se o objetivo principal desse trabalho. A partir do estudo da dinâmica da Cesta Agroecológica Campo Cidade, que tem suas ações no município de Curitiba/PR, pudemos ampliar reflexões acerca dos caminhos que a Agroecologia, nos processos de produção e consumo, percorre para chegar no público urbano. Esse trabalho é resultado de uma pesquisa de Iniciação Científica realizada de julho de 2019 a agosto de 2020, com o título "Debate sobre a alimentação no cotidiano: a importância da agricultura camponesa agroecológica”. Alguns avanços nessa pesquisa, selecionados para esse trabalho, permitiram que ampliássemos algumas reflexões, aqui compartilhadas.

A metodologia adotada consistiu em: a) revisão bibliográfica sobre as temáticas que envolvem Agroecologia, economia solidária e território; b) coleta de dados sobre a experiência da Cesta Agroecológica Campo Cidade de forma primária e secundária. Os dados coletados de origem primária foram retirados de conversas e situações observadas do grupo de Whatsapp de pedidos da Cesta, além de entrevistas semiestruturadas com dois membros do empreendimento de economia solidária Sinergia Alimentos Saudáveis, que articula o trabalho da 
Cesta. Os dados secundários foram coletados através do site oficial da Cesta Agroecológica Campo Cidade.

Assim, o texto organiza-se da seguinte maneira: primeiro, é apresentada a Cesta Agroecológica Campo Cidade e sua dinâmica de comercialização na cidade de Curitiba. Em seguida, a partir do conceito de território, evidenciamos como a agroecológica constrói territórios no campo e na cidade. Por fim, apresentamos as considerações finais, onde tecemos algumas lições sobre a Cesta Agroecológica Campo Cidade e destacamos como esses territórios agroecológicos no campo e na cidade encontram-se em rede.

\section{ALIMENTOS AGROECOLÓGICOS À MESA}

A Agroecologia surge como uma esperança a degradação ambiental e social causada pela agricultura convencional ou industrial. Feita por camponeses e baseada em conhecimentos ancestrais que derivam da observação da natureza, a Agroecologia é uma ciência definida pela integração de conhecimentos que procuram estabelecer uma produção de alimentos sem dependência de insumos químicos (ALTIERI, 2004; MOLINA, 2011; VÍA CAMPESINA, 2013). Sendo também um movimento político, coloca em pauta uma produção menos subordinada ao modelo agroalimentar, o qual controla os processos de produção, distribuição e consumo de alimentos numa escala mundial (CABEZA, 2010), bem como os debates acerca da soberania e segurança alimentar e nutricional ${ }^{8}$.

A Agroecologia, tendo como ponto de partida o campo, através dos produtores, reformula a forma que os consumidores, na cidade, veem o alimento.

8 Soberania alimentar está ligada a autonomia e poder de decisão em produzir e consumir alimentos culturalmente adequados e não dependentes do sistema agroalimentar das corporações, essencialmente marcado pela ideia de que o alimento é meramente uma mercadoria (NOBRE et al., 2014; GIORDANI; BEZERRA; ANJOS, 2017). Já a segurança alimentar e nutricional corresponde à situação em que é possível alimentar-se diariamente e consumir calorias e nutrientes necessários (NOBRE et al., 2014). O conceito de soberania e segurança alimentar e nutricional incorpora as dimensões da autonomia em relação a produção e consumo de alimentos, estabelecendo condições para uma situação alimentar segura, onde todos e todas possam se alimentar de uma forma saudável, não exploratória e não excludente. 
Opõe-se ao modelo convencional de produzir, caracterizado por ser predatório e destrutivo à natureza; ao uso exacerbado de agrotóxicos e outros insumos químicos; à concentração de terra e à fome. Inserida numa realidade marcada por conflitos que envolvem a questão alimentar, desde a produção até o consumo, a Agroecologia representa resistência perante lógicas de produção, distribuição e consumo do alimento que priorizam o lucro.

Tudo que é produzido agroecologicamente, resultante do trabalho na terra daqueles que estão no campo, tem como intuito alimentar a população. População esta que, de uma forma geral, encontra-se no meio urbano. No Brasil, cerca de $85 \%$ da população encontra-se nas cidades e na região Sul, a população vivendo nas cidades chega a 86\% (IBGE, 2010). É nesse contexto altamente urbano e repleto de desigualdades e contradições, que a Agroecologia e aquilo que é produzido por ela, vai ganhando mais visibilidade enquanto alternativa para abastecer os que vivem na cidade.

Além dos mercados institucionais, uma outra forma pela qual os alimentos agroecológicos chegam na mesa de quem está na cidade, é através da criação de mercados de proximidades. Mercados estes que fogem da lógica do sistema agroalimentar dominante, marcado por práticas oligopolizadas e excludentes (ENA, 2018), encontrando outros formatos alternativos de comercialização. Esses mercados são construídos principalmente por produtores agroecológicos, destacando os camponeses que se unem, formando uma cooperativa ou uma associação, por exemplo, de forma a somar sua produção e suas forças, comercializando com mais facilidade, ocupando espaços mais representativos na cidade e chegando com mais intensidade aos seus habitantes. A ideia de articulação entre os produtores entra na esfera da economia solidária ${ }^{9}$, que também possui um papel importante em muitas das iniciativas agroecológicas de comercializa-

$9 \quad$ A economia solidária representa uma resposta às carências que o sistema capitalista não é capaz de solucionar, tais como o desemprego e a pobreza, constituindo-se numa economia pautada sobre os pilares da inclusão, cooperação, autogestão, solidariedade e sustentabilidade (FBES, 2016; SINGER, 2001). Tem como objetivo principal propor um outro tipo de desenvolvimento, onde trabalhadores são remunerados de forma justa, transformando a realidade local e promovendo sustentabilidade. 
ção na cidade. O Fórum Brasileiro de Economia Solidária (FBES), ao destacar os empreendimentos econômicos solidários, aponta para o eixo de "Produção, comercialização e consumo". Este eixo está relacionado com a produção de alimentos agroecológicos, bem como sua comercialização, realizada em mercados mais justos e que revelam-se também espaços de troca e saberes (FBES, 2016).

É pensando na construção de mercados agroecológicos urbanos, através da união entre camponeses por meio da economia solidária, que damos enfoque neste trabalho à Cesta Agroecológica Campo Cidade. A Cesta Agroecológica Campo Cidade é uma iniciativa de comercialização de alimentos agroecológicos no município de Curitiba/PR, resultado da parceria entre uma rede de cooperativas e um empreendimento de economia solidária.

Surgindo oficialmente em 2016, a Cesta Agroecológica Campo Cidade é autogerida pelo empreendimento de economia solidária Sinergia Alimentos Saudáveis e pela Cooperativa Central da Reforma Agrária/PR (CCA-PR) ${ }^{10}$, tendo como missão "fortalecer o vínculo campo-cidade, conectando quem produz cooperativamente com quem consome conscientemente" (PRODUTOS DA TERRA, 2020f, sem página). A Cesta Agroecológica Campo Cidade é mais conhecida pela marca "Produtos da Terra" e possui como canais de comunicação um site (http://www.produtosdaterrapr.com.br/), oito grupos de Whatsapp e um Instagram (@produtos_da_terra), sendo possível fazer pedidos de alimentos e demais produtos pelos dois primeiros.

Esta iniciativa possui duas frentes relacionadas à comercialização de alimentos agroecológicos, sendo uma delas a entrega de cestas e a outra através das feiras. A entrega de cestas com alimentos agroecológicos é feita em oito pontos do município de Curitiba, cada um em um bairro diferente. Os consumidores fazem seus pedidos de alimentos agroecológicos e em determinado dia

10 O empreendimento de economia solidária Sinergia Alimentos Saudáveis trabalha em conjunto com a CCA/PR, contribuindo no processo operacional da Cesta Agroecológica Campo Cidade. É composta por quatro membros principais, que atuam nas frentes de comercialização (feiras e cestas) e de comunicação, além de contar com outros voluntários e apoiadores do projeto (PEQUENO, Luis. Curitiba, 24 mai. 2020. Informação verbal.). 
da semana, sexta-feira ou sábado (variando conforme o ponto de entrega), vão buscar seus pedidos. As feiras acontecem uma vez por semana, em dois pontos do município: no Centro, na Praça Osório (sexta-feira, das 8:00 às 14:00) e no bairro Rebouças, no estacionamento da Sindipetro (Sindicato dos Petroleiros do Paraná e Santa Catarina), todas os sábados, das 9:00 às 14:00 (PRODUTOS DA TERRA, 2020b).

A dinâmica de comercialização através da entrega de cestas, foi escolhida para ser estudada com mais profundidade. Isso porque constitui-se a frente mais forte de comercialização dentro do projeto e porque essa forma de comercialização tem uma espacialização maior dentro do município, como pode ser observado no Mapa 1.

Os consumidores têm acesso às listas de alimentos agroecológicos e outros produtos disponíveis, divulgadas através do site e através dos grupos de Whatsapp. Estas listas, atualizadas semanalmente, ficam disponíveis a partir de domingo e os consumidores devem fazer seus pedidos até segunda-feira à noite. O pagamento pode ser feito diretamente pelo site ou no momento da entrega do produto, através do cartão. Os consumidores possuem a opção de personalizar seu pedido, tendo a liberdade de escolher os alimentos e suas quantidades (a chamada "cesta aberta"), ou podem escolher uma cesta previamente montada, contendo opções e quantidades limitadas de diversas categorias de produtos, denominada "cesta fechada". Ainda, há a possibilidade de que a cesta seja entregue em casa, mediante consulta prévia e taxa de entrega. 
MAPA 1 - PONTOS DE ENTREGA DA CESTA E FEIRAS

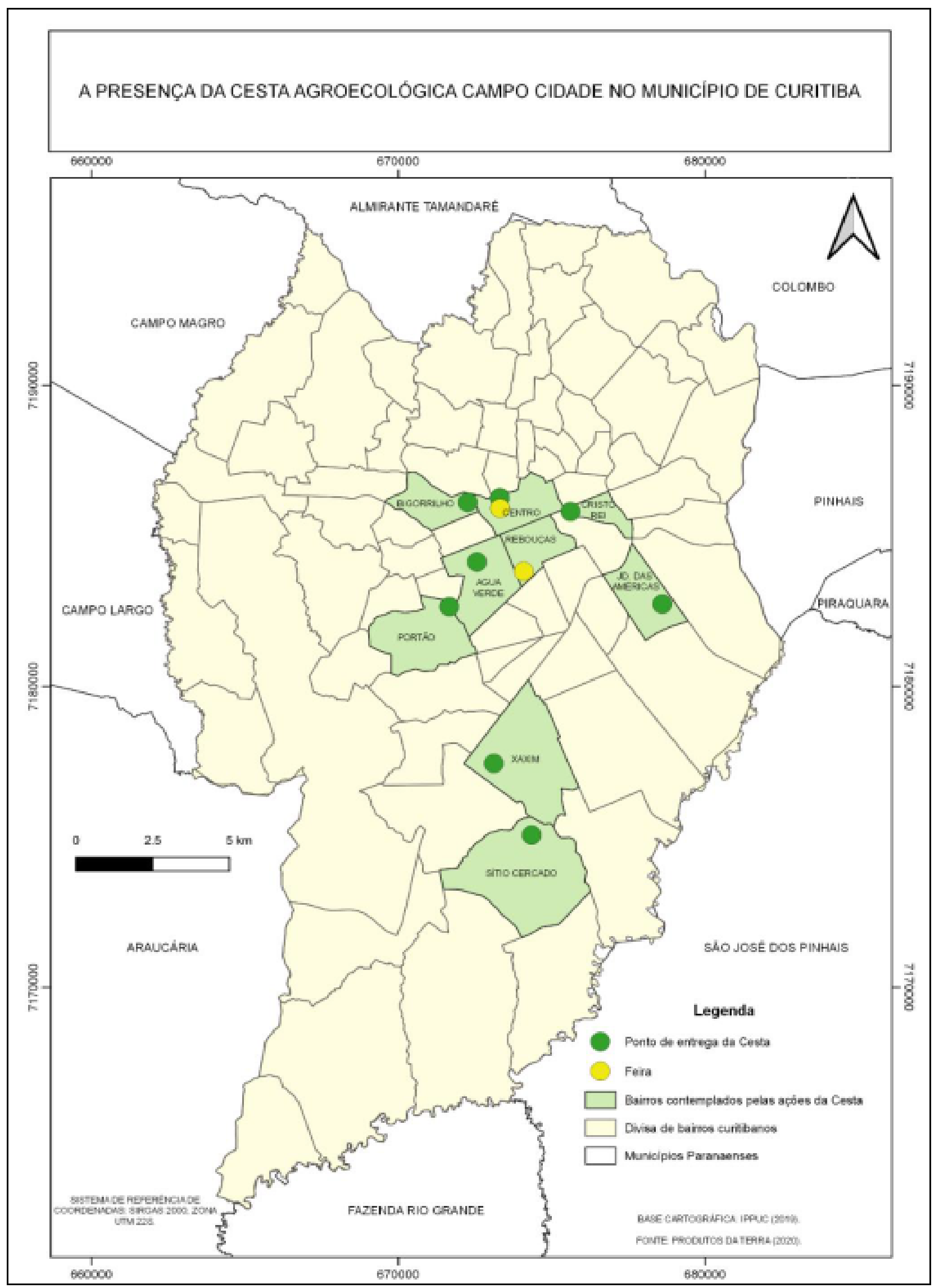

Fonte: A autora (2020). 
Os alimentos e produtos agroecológicos ofertados variam conforme a estação, período de cultivo, colheita e outros fatores que representam o respeito e equilíbrio da natureza, base da Agroecologia. As categorias de produtos disponíveis são: bebidas, cosméticos naturais, derivados de porco, ervas medicinais, foIhosas, frios, frutas, grãos e sementes, legumes e caules, mercearia, panificados, sementes agroecológicas, sucos naturais, temperos e tubérculos e raízes (PRODUTOS DA TERRA, 2020d). Alguns dos produtos, principalmente os embalados, possuem certificação de produto ecológico da Rede Ecovida ${ }^{11}$.

Estes alimentos e produtos vêm principalmente de camponeses assentados da reforma agrária, os quais estabelecem com a terra relações de produção e vivência cotidiana. Os camponeses estão vinculados à CCA/PR, uma grande rede de cooperativas no estado. Estas cooperativas têm origem em assentamentos da reforma agrária no âmbito paranaense. Entre as principais cooperativas que fazem parte desta rede, cabe destacar no âmbito do projeto da Cesta, a Cooperativa Terra Livre (representando produtores do assentamento Contestado, no município da Lapa, a 60 km de Curitiba), que fornece à Cesta Agroecológica Campo Cidade hortaliças, legumes e tubérculos (PRODUTOS DA TERRA, 2020e). É nesse sentido que a Cesta Agroecológica Campo Cidade constitui-se a ponte que possibilita que os camponeses comercializem sua produção agroecológica na cidade, ampliando o consumo desses alimentos. Prova disso é o número de cestas entregues semanalmente, conforme o quadro a seguir demonstra:

\section{QUADRO 1 - NÚMERO DE CESTAS ENTREGUES}

\begin{tabular}{|c|c|}
\hline Data da entrega & $\mathbf{N}^{\circ}$ de cestas entregues \\
\hline 16 e 17 de outubro & 111 \\
\hline 23 e 24 de outubro & 160 \\
\hline 30 e 31 de outubro & 104 \\
\hline
\end{tabular}

11 A Rede Ecovida, presente na região sul do país, busca fortalecer a produção e comercialização agroecológica. É responsável por certificar produtos agroecológicos através do Sistema Participativo de Garantia (SPG), no qual agricultores e técnicos responsabilizam-se coletivamente pela certificação daquele produto como agroecológico a partir de um sistema de vistorias (REDE ECOVIDA, 2020). 
A QUESTÃO AGRÁRIA NO BRASIL: CAMPESINATO, AGRICULTURA FAMILIAR E AGRONEGÓCIO

\begin{tabular}{|c|c|}
\hline 06 e 07 de novembro & 150 \\
\hline 13 e 14 de novembro & 113 \\
\hline 20 e 21 de novembro & 143 \\
\hline 27 e 28 de novembro & 109 \\
\hline 04 e 05 de dezembro & 159 \\
\hline 11 e 12 de dezembro & 108 \\
\hline 18 e 19 de dezembro & 153 \\
\hline TOTAL & 1.310 \\
\hline
\end{tabular}

Fonte: PRODUTOS DA TERRA (2020a). Acesso em 13 jan. 2021.

No entanto, apesar de fazer parte do cotidiano de vários consumidores curitibanos, os alimentos agroecológicos comercializados pela Cesta ainda não são tão representativos quando analisamos a população do município de Curitiba, estimada em 1.948.626 habitantes (IPARDES, 2021). Ainda que o número de cestas entregues seja considerado baixo quantitativamente, o fato de mais consumidores da cidade alimentarem-se do que vem da Agroecologia, constitui-se um grande passo perante as forças hegemônicas que rondam o alimento.

O papel dos consumidores frente à escolha do alimento agroecológico, revela um olhar mais crítico destes em relação ao sistema agroalimentar dominante. Ao optarem pela compra do alimento agroecológico, estes não o fazem apenas por conta da informação de que "agrotóxico faz mal à saúde". Analisando um pouco mais de dentro dos grupos de consumidores da Cesta Agroecológica no Whatsapp, pudemos constatar que estes consomem alimentos agroecológicos por diversas outras razões, sendo considerados, a partir de nossas interpretações, consumidores solidários.

Os consumidores solidários são caracterizados por serem aqueles que possuem uma visão mais crítica do consumo e seus impactos relacionados também à produção, situado no centro do ato de consumir questões sociais e ambientais (MANCE, 2013). Este consumidor escolhe comprar um produto que beneficie não apenas a ele mesmo, mas também àqueles que o comercializam: ou seja, para 
seu bem-estar próprio e bem-estar coletivo (MANCE, 2013). O consumo solidário deriva da economia solidária, pautada sobre ideais de cooperação, autogestão, sustentabilidade e, inclusive, empatia.

Muitos dos consumidores da Cesta Agroecológica Campo Cidade têm conhecimento (mesmo que sucinto) de quem produz esses alimentos e como eles são produzidos. Sabem que são produto do trabalho de camponeses, agricultores que dedicam sua vida a lidar com a natureza, com a terra, e dela tirar seu sustento $^{12}$. Sabem que são produzidos agroecologicamente, isto é, através de técnicas agrícolas que respeitam e não degradam o meio ambiente, e que consumindo esses alimentos, contribuem para as causas que acreditam. Isso se evidencia por meio de relatos dos próprios consumidores. Em abril de 2020, em plena pandemia de Covid-19, uma consumidora lamentou, através do grupo de Whatsapp, não poder comprar alimentos da Cesta por conta do isolamento social imposto. Ela relatou sentir falta da sensação de se alimentar de uma causa que acredita e que deposita muita fé.

É somado a estes relatos, trocas de informações e debates acerca da Agroecologia (envolvendo as temáticas da alimentação saudável, sustentabilidade, cooperação, economia solidária e esfera política) nos grupos de Whatsapp, que consideramos que os consumidores da Cesta Agroecológica Campo Cidade são solidários. Os consumidores possuem um papel ativo nessa dinâmica, construindo-a conjuntamente com todos aqueles que estão nos outros processos da Cesta (produtores e organização interna, como Sinergia Alimentos Saudáveis e CCA/ PR). Assim, o consumo deste alimento agroecológico está ligado a ideais e princípios, não sendo meramente apenas um ato econômico, mas também ético e político, como afirma Mance (2013).

12 Em janeiro de 2021, os consumidores da Cesta Agroecológica Campo Cidade foram convidados, através do grupo de Whatsapp, a se unirem ao Mutirão de Colheita do Feijão que realizou-se no Assentamento Contestado, no município da Lapa/PR. O feijão colhido seria doado para o projeto Marmitas da Terra, o qual voluntários distribuem marmitas para pessoas carentes e população de rua no período pandêmico. Outro objetivo era fazer com que os consumidores se aproximassem do cotidiano dos produtores de alimentos agroecológicos da Cesta, em especial da Cooperativa Terra Livre. 
Helena, uma das entrevistadas que faz parte da dinâmica da Cesta Agroecológica (representando o empreendimento de economia solidária Sinergia Alimentos Saudáveis), contou que grande parte dos consumidores que hoje adquirem alimentos agroecológicos, conheceram a iniciativa de comercialização através de indicações de amigos e familiares. São pessoas que compartilham suas impressões sobre a forma como consomem e incentivam outras a fazer parte deste círculo, possibilitando outros pensares sobre o alimento através do consumo. Porém, ainda que uma gama maior de pessoas venha a conhecer o projeto da Cesta Agroecológica, lembremos que há limites para a maior expansão da Agroecologia no nosso cotidiano alimentar. A hegemonia do sistema agroalimentar e da agricultura convencional dificultam que formas alternativas de produção de alimentos cheguem à mesa dos consumidores. Ainda que à passos lentos, a Cesta Agroecológica representa formas outras de fazer com que alimentos saudáveis e produzidos de forma socialmente justa, perpetrem esse sistema complexo de poder sob o alimento.

À medida que estes alimentos agroecológicos tomam conta de espaços da cidade, através da comercialização e pela sua presença na mesa dos consumidores, mais a Agroecologia evidencia sua importância para a construção de um novo modo de ver a produção e o consumo que não está apenas no campo, como também na cidade.

\section{CONSTRUÇÃO DE TERRITÓRIOS AGROECOLÓGICOS NO CAMPO E NA CIDADE}

A Agroecologia está ligada aos sujeitos do campo e da cidade, produzindo territórios em ambos os espaços. Território, de acordo com Saquet (2009), é um espaço apropriado e construído de forma coletiva, que gera identidades e heterogeneidades, além de ser marcado por relações sociais, conflitos, cooperações e outros. Chamamos, portanto, de territórios agroecológicos aqueles que tem por predominância práticas de produção e consumo de alimentos agroecológicos, 
A QUESTÃO AGRÁRIA NO BRASIL: CAMPESINATO, AGRICULTURA FAMILIAR E AGRONEGÓCIO

que constituem-se atos políticos e de resistência perante os modelos de produção hegemônicos.

O espaço apropriado pelo camponês que produz agroecologicamente é considerado um território agroecológico. O território agroecológico do camponês não é apenas um espaço de produção, mas também um espaço da experiência, do saber, do cotidiano e vivência. É um território onde a Agroecologia está no âmbito reprodutivo da vida. As práticas agroecológicas, por elas mesmas, são consideradas práticas camponesas, já que envolvem conhecimentos, técnicas, valorização do patrimônio ecológico da família (SAQUET, 2014).

A Cesta Agroecológica Campo Cidade permite que territórios agroecológicos também sejam construídos na cidade. Esses espaços, mesmo que por pouco tempo e apenas em um dia da semana, são apropriados por representantes do empreendimento de economia solidária Sinergia (responsáveis pela entrega e cobrança das cestas), bem como pelos consumidores. Esses pontos de entrega não são apenas um ponto de passagem, já que ali os consumidores compartiIham ideias, receitas, trocam informações, enfim, constroem relacionamentos. São criados laços, bem como identidades são (re)construídas, tendo como partida o consumo do alimento agroecológico. Esses territórios agroecológicos na cidade estão também nos lares, no cotidiano alimentar dos consumidores.

Os territórios agroecológicos podem ser ainda classificados como cotidianos, de acordo com a concepção de Raffestin (2003 apud SAQUET, 2008). O território do cotidiano é aquele em que realizamos nossas ações diárias, ligadas a satisfações de necessidades e às relações com os indivíduos e lugares (SAQUET, 2008). Nesse sentido, os territórios agroecológicos incitados pela Cesta Agroecológica Campo Cidade, tanto no âmbito da produção e vivência, como local de entrega das cestas ou nos lares, constituem-se também cotidianos.

Tanto o consumo como produção promovidos pela Agroecologia, revela-se uma resistência. São resistências aos modos de produção, à aquisição e consumo de alimentos que advém do sistema agroalimentar hegemônico; resistências 
perante modos de produção convencionais (com agrotóxicos, transgênicos, etc.); resistências na terra e, consequentemente, no território (referente a modos de vida específicos). Os territórios agroecológicos, cotidianos, são exemplos desses espaços de resistência, onde produzir, comercializar e consumir agroecologicamente constitui-se em um ato político. É nesse contexto que a Cesta Agroecológica Campo Cidade e seu projeto de comercialização constitui-se um exemplo do que é, em prática, a Agroecologia. Uma Agroecologia que está no campo - através da produção de camponeses assentados da reforma agrária e agricultores familiares no Paraná - e na cidade.

\section{CONSIDERAÇÕES FINAIS}

Este trabalho teve como objetivo estudar a dinâmica da Cesta Agroecológica Campo Cidade, procurando reconhecer como a Agroecologia está presente no campo e na cidade. Para isso, apresentamos inicialmente como funcionava a Cesta Agroecológica Campo Cidade e a espacialização dos pontos de entrega da cesta, mostrando que a Cesta representa a busca por alimentos produzidos e comercializados de forma não hegemônica na cidade. Depois, apresentamos os territórios construídos pela Agroecologia no campo e na cidade.

No campo, vemos que os camponeses que produzem agroecologicamente, conseguem comercializar sua produção com mais facilidade e sem atravessadores. Por meio da união desses camponeses com a CCA/PR, e pela parceria com o empreendimento de economia solidária, Sinergia Alimentos Saudáveis, mais facilitado fica seu acesso ao mercado. AAgroecologia e o trabalho da Cesta Agroecológica Campo Cidade contribuem também para que esses sujeitos, até então invisibilizados, possam fazer mais parte do cotidiano dos que estão na cidade através do alimento. A iniciativa da Cesta Agroecológica Campo Cidade mostra que a Agroecologia provê a cidade de alimento. Consumidores solidários e críticos passam a ver o consumo e o alimento de uma forma diferente com a qual estavam habituados - nos supermercados, em prateleiras, que distanciam 
produtor do consumidor. Há um despertar para o consumo de alimentos saudáveis, que não degradam o ambiente, que são produzidos por camponeses em terras de reforma agrária etc. O consumir alimentos cotidianamente, através da Agroecologia, passa a ser um ato mais reflexivo e político.

As práticas agroecológicas de produção e de consumo de alimentos agroecológicos, encontram-se materializados sobre o espaço. A Cesta Agroecológica é responsável por construir territórios agroecológicos cotidianos no campo e na cidade. Esses territórios são marcados pelo compartilhamento de ideais e modos de ver o mundo, onde se constroem-se (ou reconstroem-se) identidades. Os territórios agroecológicos cotidianos, tanto no campo, através do produzir, como na cidade, por meio da comercialização e do consumo cotidiano de alimentos agroecológicos, constituem-se em nossa análise, territórios em rede. Essas redes entre territórios, a conexão entre eles, se dá a partir das práticas objetivas, subjetivas e imateriais que ocorrem por meio de atores sociais em suas ações cotidianas (SAQUET, 2009).

Através da experiência com a Cesta Agroecológica Campo Cidade, pudemos perceber que ela aproxima campo e cidade em razão de sua forma de comercialização mais próxima e mais humana. Portanto, pudemos evidenciar a maior presença da Agroecologia no campo e na cidade, transformando espaços e pessoas. Essa presença física, fica mais visível nos territórios agroecológicos em rede, mas também é imaterial, ou seja, está nos diálogos, nas trocas cotidianas e na vivência de cada produtor e consumidor.

\section{REFERENCIAS}

ALTIERI, Miguel. Agroecologia: a dinâmica produtiva da agricultura sustentável. 4. ed. Porto Alegre: UFRGS, 2004.

CABEZA, Manuel Delgado. El sistema agroalimentario globalizado: impérios alimentarios y degradación social y ecologica. Revista de Economía Crítica, [s. I], n. 10, p. 32-61, 2010. 


\section{ENA. Carta política do IV ENA: Agroecologia e democracia unindo campo e} cidade. Rio de Janeiro: ASPTA; Articulação Nacional de Agroecologia - ANA, 2018.Disponível em: <http://enAgroecologia.org.br/files/2019/03/carta_politica_ web.pdf>. Acesso em: 20 set. 2020.

FBES. Boas práticas em economia solidária no Brasil. Brasília: CEA; FBES, 2016. Disponível em: <https://fbes.org.br/download/boas-praticas-em-economia-solidariano-brasil/> . Acesso em: 15 set. 2020.

GIORDANI, Rubia Carla Formighieri; BEZERRA, Islândia; ANJOS, Mônica da Caldas Rosa dos. Semeando Agroecologia e colhendo nutrição: rumo ao Bem e Bom Comer. In: SAMBUICHI, Regina Helena Rosa et al. (Orgs.). A política nacional de Agroecologia e produção orgânica no Brasil: uma trajetória de luta pelo desenvolvimento rural sustentável. Brasília: IPEA, 2017. p. 433-454.

IBGE. Sinopse do Censo Demográfico 2010: população residente, por situação do domicílio e sexo, segundo as grandes regiões e as unidades da federação 2010. População residente, por situação do domicílio e sexo, segundo as Grandes Regiões e as Unidades da Federação - 2010. 2010. Disponível em: https:// censo2010.ibge.gov.br/sinopse/index.php?dados=11\&uf=00. Acesso em: 03 set. 2020.

MANCE, Euclides André. Consumo Solidario.In: CATTANI, A.D.; CORAGGIO,J.L.; LAVILLE, J.L. (Orgs.). Diccionario de laotra economia. $2^{a}$ edição. Los Polvorines: Universidad Nacional de General Sarmiento, 2013. 86-92.

MOLINA, Manuel González de. Introducción a la Agroecología. SociedadEspañola de Agricultura Ecológica (SEAE), 2011. Disponível em: https://aba-agroecologia.org.br/download/introduccion-a-la-agroecologia-m-gonzalez-de-molina-seae-2011/. Acesso em: 14 set. 2020.

NOBRE, Miriam Nobre Pacheco et al. Economia Feminista e Soberania Alimentar. 2014. Disponível em: <http://www.sof.org.br/economia-feminista-esoberania-alimentar-avancos-e-desafios/>. Acesso em: 10 set. 2020.

PRODUTOS DA TERRA. Essa semana foram 153 cestas agroecológicas campo-cidade pedidas!. 2020a. Disponível em: < https://www.produtosdaterrapr.com.br/2020/12/17/essa-semana-foram-153-cestas-agroecologicas-campo-cidade-pedidas-2/>. Acesso em: 13 jan. 2021. 
PRODUTOS DA TERRA. Feiras. 2020b. Disponível em: <http://www.produtosdaterrapr.com.br/feiras/>. Acesso em: 01 set. 2020.

PRODUTOS DA TERRA. Pontos de entrega. 2020c. Disponível em:<http://www. produtosdaterrapr.com.br/entregas/>. Acesso em: 01 set. 2020.

PRODUTOS DA TERRA. Produtos. 2020d. Disponível em: <http://www.produtosdaterrapr.com.br/produtos/>. Acesso em: 01 set. 2020

PRODUTOS DA TERRA. Rede de Cooperativas da Reforma Agrária. 2020e. Disponível em: <http://www.produtosdaterrapr.com.br/ccapr-rede-de-cooperativas-da-reforma-agraria-do-parana/>. Acesso em: 03 set. 2020.

PRODUTOS DA TERRA. Quem Somos. 2020f. Disponível em: <http://www.produtosdaterrapr.com.br/apresentacao/>. Acesso em: 01 set. 2020.

REDE ECOVIDA. Como a Rede Funciona: certificação participativa. Certificação participativa. 2020. Disponível em: <http://ecovida.org.br/sobre/>. Acesso em: 15 set. 2020.

SAQUET, Marcos. Agricultura camponesa e práticas (agro)ecológicas. Abordagem territorial histórico-crítica, relacional e pluridimensional. Mercator, Fortaleza, v. 13, n. 02, p.125-143, 26 set. 2014. Mercator - Revista de Geografia da UFC. http://dx.doi.org/10.4215/rm2014.1302.0009. Disponível em:

SAQUET, Marcos Aurélio. Por uma abordagem territorial. In: SAQUET, Marcos Aurélio; SPOSITO, Eliseu Savério (Orgs.). Territórios e territorialidades: teorias, processos e conflitos. $1^{a}$ edição. São Paulo: Expressão popular: UNESP. Programa de Pós Graduação em Geografia, 2009. p. 73-94.

SINGER, Paul. Economia solidária versus economia capitalista. Sociedade e Estado, Brasília, v. 16, no 1-2, p.100-112, jun./dez. 2001. Disponível em: <https:// www.scielo.br/scielo.php?script=sci_arttext\&pid=S0102-69922001000100005>. Acesso em: 3 maio 2020.

VÍA CAMPESINA. De Maputo a Yakarta: 5 años de agroecologia en la vía campesina. 5 Años de agroecologia en La Vía Campesina. 2013. Disponível em: https://viacampesina.org/es/wp-content/uploads/sites/3/2013/07/De-Maputo-a-Yakarta-ES-web.pdf. Acesso em: 08 set. 2019. 
dol 10.48209/978-QR-89949-10-6

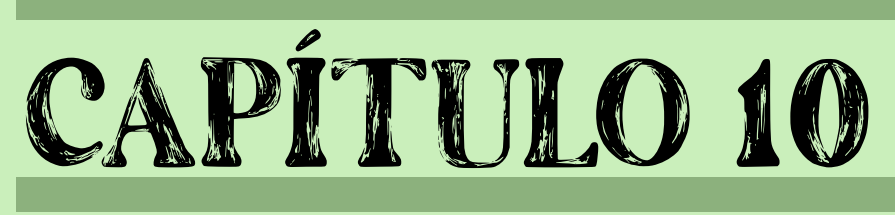

\section{DO CONSUMO SELETIVO À NECESSIDADE DE} UNIVERSALIZAÇÃO DOS PRODUTOS ORGÂNICOS

Geovânio Silva Santos

Josefa de Lisboa Santos Tiago Barreto Lima 


\section{INTRODUÇÃ ${ }^{13}$}

Nos últimos 30 anos o consumo de produtos transgênicos tem crescido consideravelmente. Associado a este processo, a utilização de agrotóxicos segue um movimento similar, visto a complementaridade dessas duas facetas do alto desenvolvimento das forças produtivas capitalistas, sobretudo no agronegócio.

Esse quadro despertou para que algumas perguntas emergissem, tais como: por que o Brasil é o segundo maior consumidor de transgênicos do mundo? Por que é também o maior consumidor de agrotóxicos do planeta? Por que a espacialização desse mercado é tão promissora nos países periféricos? Por que não optar pela produção de orgânicos? Qual o papel do Estado perante a intrusão massiva de agrotóxicos e transgênicos? O orgânico é mais caro? Quais as facetas do seu consumo? O modelo de agricultura vigente busca produzir alimentos ou commodities?

Foi a partir desses pressupostos que buscamos respostas ao movimento real e desigual da produção do espaço, que tem na difusão de alimentos envenenados e geneticamente transformados o carro chefe do agronegócio brasileiro.

Como rebatimento, temos a produção agrícola e as terras agricultáveis majoritariamente destinadas a esse tipo de atividade em detrimento da produção saudável voltada para a mesa do trabalhador-consumidor. Essa última ainda é pequena e tem no consumo seletivo sua expressão concreta. Sendo o capitalismo um sistema movido por contradições genéticas, a conflitualidade de classes na produção de commodities, tem seu par dialético na produção de alimentos orgânicos, produzidos quase que em sua totalidade pelo campesinato.

A agricultura orgânica camponesa se propõe de forma necessária como expressão da soberania alimentar, por ser uma alternativa potencial para reprodução humana através de uma alimentação saudável. Com princípios próximos

13 Artigo apresentado no IX Simpósio Internacional de Geografia Agrária e X Simpósio Nacional de Geografia Agrária, na cidade de Recife, Pernambuco, em 2019. 
da agroecologia, esse tipo de agricultura tem na relação de respeito à natureza uma das suas principais características.

Porém, observamos que apesar de considerável crescimento na produção, o consumo se dá de forma seletiva, obedecendo a critérios muito específicos, como renda e nível de escolaridade ${ }^{14}$. E ao contrário do que dizem os apologistas do agronegócio, a produção camponesa demonstra melhores índices de produtividade.

É neste sentido que nossa pesquisa se faz relevante. Objetivamos demonstrar a necessidade de universalização dos produtos orgânicos. Para tanto, partimos da leitura da realidade a partir da perspectiva da dialética materialista, a fim de apreender as determinações que compõem a dinâmica do objeto em questão.

Nos atentaremos então ao consumo de orgânicos no município de Itabaiana/SE, propiciado pela Associação de Produtores Orgânicos do Agreste - ASPOAGRE. Nela, camponeses dos municípios de Malhador, Itabaiana, Areia Branca e Frei Paulo, se organizaram para comercializar sua produção, ampliando seu acesso.

Metodologicamente, somamos à leitura teórica, trabalhos de campo direcionados à Associação, entrevista com o presidente, e aplicação de questionários aos consumidores. Através dos questionários percebemos, então, que o consumo de produtos orgânicos em Itabaiana/SE se dá de forma seletiva, visto a tímida produção no município e arredores, fazendo dos mesmos, alimentos de luxo.

Assim, a necessidade de universalização dos produtos orgânicos deve ser apontada como horizonte a ser alcançado, sem descolar-se da necessidade de democratização do acesso à terra.

De forma sucinta, abordaremos então como o agronegócio, enquanto expressão da agricultura moderna capitalista, tem nas sementes transgênicas e

14 Critérios expostos nos questionários aplicados aos consumidores. O objetivo era identificar o perfil social dos sujeitos. 
nos agrotóxicos a materialização do capital no campo, incidindo sobre as relações sociais contraditórias do sociometabolismo do capital.

\section{O AGRONEGÓCIO, AS SEMENTES TRANSGÊNICAS E A (AGRO) TOXIDADE PRODUTIVA}

Antes de falarmos sobre o agronegócio, achamos pertinente abordar o processo histórico de consolidação do mercado de transgênicos e de agrotóxicos.

O Brasil ser o maior consumidor de agrotóxicos e o segundo maior consumidor de transgênicos do mundo, não é por acaso. O processo histórico tem seus alicerces na própria formação territorial brasileira, assentada na exploração do trabalho e degradação da natureza. Ao institucionalizar a propriedade privada, a Lei de Terras de 1850 (BORGES, 2011) propiciou o alastramento do domínio da classe latifundiária, e ao mesmo tempo a posição do Brasil na divisão internacional do trabalho.

Mesmo com uma agricultura quase que exclusivamente voltada para exportação, o momento histórico não condicionava o desenvolvimento das forças produtivas no campo, como veremos de fato no século $X X$, sobretudo na segunda metade. Além do mais, o país era dominado por uma paisagem rural, com relações sociais de produção arcaicas, que perduram em conteúdo até os dias de hoje.

No século XX, sobretudo após as duas Grandes Guerras, as forças produtivas se desenvolvem em um patamar nunca visto antes. Simultaneamente, a agricultura vai aos poucos tendo uma base técnica mais eficiente, ao passo que a própria ciência seguiu potencializando a capacidade de transformação da natureza segundo as necessidades do capital.

O ponto de congruência entre o processo de formação territorial brasileira e o agronegócio se dá em dois aspectos. De um lado, a manutenção da subserviência ao capital estrangeiro, de modo a fornecer matéria-prima a ser transformada. 
Do outro, como condição necessária para o primeiro, avançando na concentração de terra para expandir cada vez mais os (mono)cultivos de commodities.

Assim, na contramão do que deveria ser uma agricultura voltada para a "reprodução da vida" (LIMA, 2016, p.10), as terras voltadas para a produção de milho, soja e cana-de-açúcar ${ }^{15}$, sobretudo, para exportação, são espaços pelos quais se dão o uso intensivo de agrotóxicos e a disseminação das sementes transgênicas.

Existe então um processo de espacialização de uma agricultura cada vez mais em mundialização, e que resulta das transformações decorrentes da tendência aos investimentos em capital constante ${ }^{16}$. A chamada Revolução Verde é um exemplo concreto. Iniciada entre as décadas de 1960/1970, propagava como solução para a fome maior investimento em ciência e tecnologia, como as sementes híbridas. Além disso, segundo Lima (2016) a investida do capital financeiro tem bases na própria Revolução Verde.

Pois, como afirma o autor

através da mesma, o capital financeiro - por meio do capital portador de juros - ofereceu várias modalidades de crédito para o aumento da produtividade e para melhoria das técnicas de cultivo e pesquisas de sementes (o processo de hibridização genética) (LIMA, 2016, p. 4).

A biotecnologia dos transgênicos é resultante dessas pesquisas realizadas no preâmbulo da reestruturação produtiva e daquelas anteriormente realizadas na fabricação das armas da Segunda Guerra Mundial. E a Revolução Verde representou então o avanço da agricultura capitalista, de base técnica, e, citando Porto-Gonçalves (2011) de esvaziamento do caráter político que a fome possui.

Assim, o aumento da composição orgânica do capital, representado pela introdução de mais trabalho morto no campo, resulta dos altos investimentos nas

15 (HESPANHOL, 2013; GAMA, 2016; OLIVEIRA, 2016).

16 Designa-se como capital constante a parte em que o capitalista investe em trabalho morto, em meios de produção, tais como máquinas. Essa porção de capital [...] "não altera sua grandeza de valor no processo de produção" (MARX, 1983, I apud NETTO; BRAZ, 2012, p. 114). Ou seja, se mantém constante. 
forças produtivas capitalistas, com a relação simbiótica entre ciência-saúde-agricultura (PORTO-GONÇALVES, 2011). O corolário foi a criação de conglomerados do ramo de sementes e fertilizantes, formados através da concentração e centralização de capitais na era do capital monopolista.

Da tendência à elevação das forças produtivas, intensificam-se as pesquisas em biotecnologia ${ }^{17}$, face da ampla e complexa divisão internacional do trabaIho, materializando-se no surgimento de empresas na década de 90, ligadas ao complexo produtivo de sementes transgênicas e de fertilizantes.

Este mercado que hoje movimenta bilhões, inclusive no mercado financeiro, é alicerçado pela descoberta dos transgênicos. Logo os transgênicos ocuparam posição de destaque nos oligopólios, sendo a soja um exemplo emblemático, chegando a dominar quase que por completo o mercado, em detrimento das convencionais.

Para o mesmo autor, seis empresas possuem o monopólio dessas sementes no mundo, dentre elas estão a DuPont, a Pioneer, Syngenta e a Monsanto ${ }^{18}$. Porém, algo para se pensar é que em duas décadas o consumo desses produtos aumentou cem vezes, enquanto que na Europa teve seu uso proibido.

As influências na saúde são de dimensões consideráveis. E como os casos de intoxicação acompanham os de disseminação, a tentativa/concretização do suicídio é uma das suas mais violentas facetas. As transformações no mercado dos agrotóxicos - e de transgênicos -, contribuem não só para a territorialização do capital, mas também enquanto expressões da perca da soberania alimentar.

17 Isto faz com que aumente a rapina das transnacionais, sobretudo, estadunidenses e europeias, na rica biodiversidade dos países de economia periférica. Ao mesmo tempo, a mutação artificial das espécies provoca o desequilíbrio ecológico ameaçando a própria reprodução da espécie humana, que acaba sofrendo com as alterações na natureza.

18 "Sendo a maior multinacional na elaboração de sementes transgênicas, a empresa dedica-se a buscar controlar a reprodução da vida, por meio de mercadorias que empobrecem os solos e tornam os camponeses dependentes de suas invenções patenteadas - a exemplo do famigerado Roundup - e por meio da proposital contaminação de campos cultivados com semente crioula" [...] (LIMA, 2016, p. 10). 
Quanto ao conceito de soberania alimentar, o mesmo é entendido pelos movimentos sociais, como o envolvimento "da necessidade da autonomia para a produção e comercialização de alimentos básicos e diversificados, acesso aos mercados locais, à terra e à água" (ROSA; SERGIO, 2016, p. 02). Ou seja, envolve um conjunto de necessidades sociais básicas do campesinato.

É importante ressaltar que dos agrotóxicos mais utilizados, grande parte são proibidos na União Europeia, e o seu uso ilegal é corriqueiro no Brasil, visto as flexíveis e neoliberais leis de fiscalização. E esta é apenas uma das formas pelas quais o agronegócio é beneficiado pelo Estado.

Na natureza, a relação dialética entre variedade e eficácia dos agrotóxicos, e a perca de biodiversidade, nega a sua necessária manutenção para o equilíbrio ecológico, favorecendo a manutenção do capital. Este, que avança sem limites mínimos, não poupa recursos para consolidar sua potência no campo.

Por isso, seu avanço predatório altera radicalmente a dinâmica ecológica, contribuindo para o surgimento de doenças, como a própria Covid-19. O potencial destrutivo do agronegócio está produzindo o processo de extinção global em massa, e a pandemia de Covid-19 pode ser colocada como sua expressão mais fenomênica.

Apesar de optarmos, para fins didáticos, por trazer a discussão da toxidade que envolve a produção monocultora capitalista, o agronegócio não esgota sua essência na agropecuária. Assim, a confluência entre os diferentes tipos de capitais - agrário, industrial e financeiro - no campo é característica própria do agronegócio.

O termo agronegócio surge da então necessidade de conceituação das transformações que ocorriam no espaço agrário tanto em escala nacional, quanto internacional.

Lima (2016) citando Campos (2011) esclarece

que o agronegócio não pode ser confundido como uma mera produção agrícola capitalista, uma vez que se trata de uma agricultura capitalista plasmada num contexto de singular mobilidade do capital e forte atuação 
dos conglomerados multinacionais. É uma complexa relação que associa os conglomerados multinacionais, as instituições financeiras (bancos, fundos de investimento, fundos de pensão entre outros), os grandes proprietários de terras, os laboratórios de investigação em biotecnologia/ engenharia genética e o suporte do Estado, irmanados no objetivo de garantir a reprodução ampliada do capital, sobretudo fictícia, por meio da mercantilização do bem indispensável à vida - a terra - e de tudo que a envolve (CAMPOS, 2011 apud LIMA, 2016, p. 05).

Sua evolução conceitual remonta, a uma análise sistêmica da agricultura, procurando abordar não só a produção em si, como também a distribuição, circulação e consumo das mercadorias. "Enfim, articulações à montante e à jusante do processo agrícola propriamente dito" (CAMPOS, 2011, p. 102).

A perspectiva sistêmica passa a ser adotada para explicar como se dá a cadeia produtiva dos diferentes tipos de produtos. Nos Estados Unidos, na década de 1950, David e Goldberg embasaram-se na matriz insumo-produto, proposta por Leontief (1941), articulando a agricultura com as interferências externas a ela. Um pouco mais tarde, na França, Louis Malassis elabora o conceito de filière, ou sistema agroindustrial. No Brasil, Guimarães (1978), foi o primeiro autor a utilizar essa perspectiva. Posteriormente a noção de Complexo Agroindustrial (CAI) é usada por autores como Graziano da Silva (1981;1996) e Delgado (1985). Enfim, criada em 1993, objetivando representar, sobretudo, os interesses da burguesia industrial, a Associação Brasileira de Agrobussiness (ABAG) passa a adotar o termo agronegócio, traduzido em meados da década de 1990 (HESPANHOL, 2013).

Apontando para uma perspectiva crítica, Campos (2011) argumenta que no Brasil o termo não se esgota apenas na tradução mecânica dos termos filière ou Agrobussiness. No país, o conceito se confunde com a estrutura social marcada pela concentração de terra, e com a irresoluta questão agrária.

Ao surgir no contexto do Estado neoliberal, o agronegócio apoia as políticas dessa forma de Estado, pautado nas privatizações, terceirizações e parcerias público-privadas. Outrossim, também atua legitimando o arrefecimento do 
investimento estatal em políticas sociais como saúde, previdência, educação, proteção aos recursos naturais e regulação do mercado de trabalho.

Contraditoriamente, defende "políticas protecionistas, créditos subsidiados e investimentos estatais para viabilizar maior capacidade produtiva e rentabilidade aos setores do agronegócio" (CAMPOS, 2011, p. 108). Isto demonstra a quem serve o "Estado mínimo", que os defensores do neoliberalismo reivindicam. Sua atuação tem na flexibilização das leis ambientais, além da ação no sentido de perdoar dívidas bilionárias ${ }^{19}$ a expressão de quão perene é a ação do Estado no subsídio ao Agronegócio.

Ressalta-se que a toxidade produtiva ${ }^{20}$ do agronegócio se dá não só através da intrusão massiva de transgênicos e agrotóxicos. Socialmente, tem na concentração de terra expressão concreta. Assim, traz como impossibilidade que impede, por exemplo, que se coma bem no campo e na cidade. Uma vez que mesmo sendo o campesinato o responsável por alimentar ${ }^{21}$ o trabalhador, através da monopolização do território, o capital subjuga o camponês através de seu assalariamento, ou não, ocasionando um processo de subjugação diferencial, singular em cada fração do território.

Logo, temos no Brasil uma relação simbiótica entre concentração fundiária-agronegócio-Estado, como bem nos lembra Campos (2011). O primeiro, como componente do processo histórico e da não ruptura da hegemonia do poder ma-

19 O governo Bolsonaro quer perdoar 17 bilhões de reais dos ruralistas relacionado ao Funrural, imposto ligado a contribuição previdenciária. Disponível em: <https://www.brasildefato.com.br/2019/04/12/previdencia-governo-propoe-reforma-mas-quer-perdoar-divida-bilionaria-de-ruralistas/>. Acesso em: 27 de out. de 2019. Entidades atuam no sentido de pressionar o governo a seu benefício. Disponível em: <https://www.brasildefato.com.br/2020/11/11/ruralistas-se-articulam-para-obter-perdao-bilionario-das-dividas-do-funrural>. Acesso em: 20 nov. 2021.

20 É produtiva do ponto de vista do envolvimento na dinâmica sociometabólica do capital, do lucro imediato. Em termos de produtividade, a nota seguinte aponta um pouco de como se dá a contradição com a produção camponesa.

21 Apesar de ficarem com menor parte da riqueza produzida, os camponeses "são responsáveis pela produção de $70 \%$ do feijão, $87 \%$ da mandioca, $38 \%$ do café, $46 \%$ do milho e $34 \%$ do arroz no país. Na pecuária garantiram $59 \%$ dos suínos, $50 \%$ das aves, $30 \%$ da carne bovina e 58\% do leite" (FERNANDES; WELCH; GONÇALVES, 2014, p. 19). Assim, o campesinato é responsável por boa parte da produção dos bens de consumo do trabalhador. 
terial, que é a propriedade da terra. Possui representantes no Legislativo, Executivo e Judiciário. Buscam a ampliação da concentração de terra/riqueza através da interferência direta nas decisões políticas do país.

Coerentemente, concordando em concepção teórico-metodológica com Lima (2016), reforçaremos o significado do agronegócio conforme Campos (2011)

O agronegócio deve ser compreendido como uma complexa articulação de capitais direta e indiretamente vinculados com os processos produtivos agropecuários, que se consolida no contexto neoliberal sob a hegemonia de grupos multinacionais e que, em aliança com o latifúndio e o Estado, tem transformado o interior do Brasil em um lócus privilegiado de acumulação capitalista, produzindo, simultaneamente, riqueza para poucos e pobreza para muitos e, por conseguinte, intensificando as múltiplas desigualdades socioespaciais (CAMPOS, 2011, p. 109).

Compreendemos que o agronegócio, como bloco articulado de capitais, revela sua face bárbara (CAMPOS, 2011), no aumento da insegurança alimentar no Brasil. Isso especialmente nesse contexto de pandemia, com aumento da fome no país, concomitante ao aumento exportações do agronegócio. Percebe-se então que esta forma de produção, pautada na reprodução ampliada do capital, não produz alimentos, mas sim fome.

Contudo, alternativas em potencial são colocadas em relevo contra a (agro) toxidade do agronegócio. Dentre elas, destacam-se a "Agricultura Biodinâmica, Agricultura Orgânica, Agricultura Natural e Agroecologia, Agricultura Biológica, tecnologia apropriada e agricultura ecológica" (MATOS, 2010, p. 8).

Baseadas em relações mais íntimas e diversificadas com a natureza, essas formas de produzir são geralmente atreladas a comunidades indígenas, quilombolas, camponeses que assumem uma postura de crítica à estrutura, além dos movimentos sociais e povos tradicionais.

No presente trabalho nos atentaremos à agricultura orgânica, e sua espacialização no município de Itabaiana, refletindo sobre a organização dos camponeses na Associação de Produtores Orgânicos do Agreste - ASPOAGRE, tal como o consumo seletivo que se dá na localidade imersa na totalidade. 
A QUESTÃO AGRARIA NO BRASIL: CAMPESINATO, AGRICULTURA FAMILIAR E AGRONEGÓCIO

\section{APONTANDO PARA NOVOS HORIZONTES: A ASSOCIAÇÃO DE PRODUTORES ORGÂNICOS DO AGRESTE E A SELETIVIDADE DO CONSUMO}

Ressalta-se mais uma vez que a produção dominada pela lógica destrutiva do capital, na busca pela reprodução ampliada, incessantemente prioriza a produção de commodities, ao invés de alimentos. Neste sentido, afeta não só a vida do trabalhador através da alimentação - ou da falta dela -, como também destrói seu corpo orgânico/inorgânico, a natureza.

Na contramão deste processo, o campesinato tem buscado na produção de orgânicos resistir na terra e produzir voltado para mercados locais. A Agricultura Orgânica se desenvolve, segundo Matos (2010) ainda em meados do século XX, e remonta às suas primeiras décadas. Através de pesquisas feitas na Índia, e de observar os agricultores que não utilizavam compostos químicos e possuíam resultados melhores na produção, como a menor incidência de doenças, o inglês Albert Howard, foi pioneiro no estudo de desse tipo de produção.

Compreendida como um sistema, a abordagem de aplicação da Agricultura Orgânica tem nas (agri)culturas, a utilização dos próprios restos orgânicos de animais e plantas, fazendo com que a matéria e energia permaneçam em um ciclo constante de reprodução. Desse modo, o equilíbrio ecológico se mantém, e faz com que as possibilidades de eficiência na produção sejam concretas.

O uso de componentes autóctones são também formas de manutenção do equilíbrio ecológico. Além disso, um outro aspecto crucial é a policultura. Esta forma de produzir faz com que o solo não seja exaurido através do uso intensivo e predatório de seus nutrientes. Assim como a rotação de culturas, contribuindo para que a riqueza natural do solo esteja sempre se renovando.

A prática de produção orgânica tem destaque no Brasil e uma característica é a organização dos produtores em associações ${ }^{22}$. Além disso, a socialização das práticas e a criação de mecanismos de certificação, são comumente pre-

22 Em Sergipe temos o exemplo concreto da ASPOAGRE. 
A QUESTÃO AGRÁRIA NO BRASIL: CAMPESINATO, AGRICULTURA FAMILIAR E AGRONEGÓCIO

sentes nessa forma de produzir. Sabe-se que muitos produtores se voltam para o mercado na busca de autonomia para poder produzir como desejam. Mas se deparam com dificuldades como a falta de infraestrutura, em relação a irrigação e transporte, sobretudo.

O Brasil vem registrando aumento no número de produtores orgânicos, tal como de unidades de produção. E a pressão para o aumento envolve a busca de uma alimentação mais saudável. Dados do Ministério da Agricultura, Pecuária e Abastecimento registraram um salto de 5,9 mil produtores registrados em 2012, para mais de 17 mil em 2019. Concomitantemente, as unidades de produção registraram um crescimento de em média 5,5 mil em 2010, para mais de 20 mil em 2018.

Entende-se que comercialização de orgânicos em Sergipe, acompanha o movimento similar ao que se dá por todo o país. Assim, tem crescido consideravelmente (SANTOS e SOUZA, 2012 apud ROSA; SERGIO, 2016). E sua qualidade é confirmada por instâncias deliberativas como a "Certificação, os Sistemas Participativos de Garantia e o Controle Social para a venda direta sem certificação" (ROSA; SERGIO, 2016, p. 05).

Iniciada no povoado Junco, no município de Areia Branca/SE, a produção de orgânicos em Sergipe se dá em meio a negação da adoção de práticas "modernas", influenciadas pela já citada, Revolução Verde. Conforme Rosa e Sergio (2016), o ponto de partida se deu em 1986, pela iniciativa de um camponês do Agreste, na época sapateiro, mas que usou as terras, herança de família, para produzir em consumo próprio e para comercialização.

Ao fazer um curso sobre as práticas de produção orgânica, o mesmo foi se convencendo da necessidade de produzir nesse sistema. Entretanto, uma das grandes questões que impedia seu avanço, eram os caros investimentos na certificação dos produtos, uma vez que a pouca renda gerada pela comercialização seria em boa parte direcionada para a certificação. 
A Associação de Produtores Orgânicos do Agreste surgiu há mais ou menos 20 anos, da necessidade de organização dos camponeses comercializarem seus produtos, podendo aumentar sua renda. Com culturas de expressão local, os principais alimentos produzidos são macaxeira, inhame, vagem, mamão, repolho, batata-doce, beterraba, tomate cereja, mandioca, banana, cenoura e hortaliças, como coentro, cebolinha, couve, alface ${ }^{23}$, etc... Além disso, comercializam produtos transformados como doces de leite, goiaba, banana e vinho artesanal, que poderiam ser potencializados através da agroindústria da associação, que possui alguns equipamentos, mas que está fechada por conta da falta de recursos.

Diariamente chegam alimentos, sendo o sábado o dia de maior abrangência, mesmo dia em que ocorre uma das feiras ${ }^{24}$ do município. Embasada em quase que sua totalidade no conhecimento tradicional, a agricultura orgânica, no caso da ASPOAGRE, tem sua certificação garantida rigidamente pela Associação de Certificação Instituto Biodinâmico - IBD. Apesar das dificuldades na certificação, a garantia dos produtos certificados provoca confiança por parte dos consumidores.

Voltados em parte para comercialização nas lojas localizadas em Itabaiana e Aracaju ${ }^{25}$, há uma divisão do trabalho da qual cada agricultor produz o que mais é propício em suas respectivas localidades. Mesmo se dando conta do preço um pouco mais elevado que nas feiras, os consumidores, a fim de comer de forma saudável, compram da mesma forma.

Percebemos que a produção de orgânicos, assim como o seu consumo, ainda são restritos, sendo uma opção por quem produz e um privilégio para quem consome. Como há ainda pouca produção, há rápida comercialização, e os con-

23 Dados obtidos através dos trabalhos de campo, e de entrevista com o presidente da associação.

$24 \quad$ Na feira são comercializados produtos resultantes da agricultura convencional. Além da ASPOAGRE, há a comercialização de orgânicos através da Cooperativa de Produção Sustentável de Sergipe (Coopersus).

25 "01 no calçadão da Rua Treze de maio, Itabaiana. E 03, em bairros da Zona Sul de Aracaju" (ROSA, SERGIO, 2016, p. 08). 
A QUESTÃO AGRÁRIA NO BRASIL: CAMPESINATO, AGRICULTURA FAMILIAR E AGRONEGÓCIO

sumidores chegam muito cedo para comprar nos locais de venda, no nosso caso, na associação. E através de trabalhos de campos realizados no ponto de venda, e de entrevista com o presidente, vimos que há uma visão da terra com valor de uso que extrapola as relações capitalistas de produção.

É importante que tenhamos em mente que a produção e comercialização de orgânicos no município se apresenta enquanto forma de resistência à ofensiva do agronegócio. Basta um curto passeio no centro da cidade para notar o número de lojas que vendem fertilizantes, sementes transgênicas, agrotóxicos e demais produtos que visam a produtividade, mesmo que ela venha a degradar tanto as terras, quanto os trabalhadores. Representantes da alemã Bayer e da Suíça Syngenta, podem ser facilmente vistas nas ruas supracitadas.

Em escala nacional, o Conselho Brasileiro da Produção Orgânica e Sustentável (Organis), vem desenvolvendo pesquisas relativas ao consumo de orgânicos e segundo a organização, este consumo - assim como na ASPOAGRE - é elitista e denota a práticas individualistas, nas quais a preocupação com a saúde é o principal motivo da procura dos orgânicos. No ano de 2019 , foram aplicados questionários e elaborou-se um relatório que envolve critérios diversos, que tinha como um dos objetivos identificar e registrar o perfil social dos consumidores. Observou-se que nem $20 \%$ dos brasileiros consome orgânicos, o que é um tanto grave, não só do ponto de vista individual, quando público, uma vez que o consumo de alimentos envenenados afeta substancialmente a saúde pública.

Dito isso, percebemos que dentre as motivações que mais levam ao consumo de orgânicos, a preocupação com a saúde é a que predomina, visto a onda de agrotóxicos que transgrede no país. A seletividade do consumo se mostra muito clara. Uma das perguntas questionava os motivos para não haver aumento do consumo ou por não optar por orgânicos, constatando-se que se dá em predominância por conta do preço. Das principais dificuldades, este critério específico é um divisor de águas, pois é o que acaba ocorrendo de forma análoga em Itabaiana. 
No decorrer da pesquisa propomos questões que demarcassem o perfil social dos consumidores quais são direcionados os alimentos orgânicos. Na aplicação dos questionários, vimos que a grande parte residia na cidade. O que chamou atenção foi a presença de pessoas que residem no campo e se direcionavam à associação para comprarem. Uma das clientes afirmou que apesar de também cultivar orgânicos, precisa consumir alguns que não são plantados por ela.

Em outra questão buscamos compreender qual a profissão da comunidade, destacando sua variedade. Além de uma boa quantidade de aposentados, destacam-se os servidores públicos como a grande maioria dos compradores. $E$ desses, boa parte eram professoras. Este fato já aponta para um papel crucial da educação alimentar.

A busca por uma alimentação saudável decorre da compreensão de quão danoso é o consumo de produtos geneticamente modificados e dos agrotóxicos a eles associados. Por isso, envolve condições subjetivas e que demonstram critérios de clivagem social por aqueles que consomem, uma vez que o acesso à educação de qualidade é ainda seletivo no país. Dentre os clientes, a maior parte possui o ensino médio e ensino superior completos, respectivamente.

Em termos mais precisos, 35\% deles possuíam o ensino médio completo. Somando-se aqueles com ensino superior, totalizam-se $70 \%$ dos consumidores. Consideramos este um critério essencial para se compreender o consumo seletivo de produtos orgânicos, uma vez que boa parte da população parece estar a par da toxidade que o agronegócio produz. E não seria para menos. Os mecanismos de manipulação ideológica utilizados pelo agronegócio, envolvem o bombardeio de propagandas enganosas igual ou em maior grau à disseminação de agrotóxicos.

Outrossim, a educação envolve também as possibilidades de aumento de renda, o que pode ser comprovado cruzando os dados. Aqueles que possuíam um maior nível de escolaridade, possuíam também a maior faixa de renda. So- 
A QUESTÃO AGRÁRIA NO BRASIL: CAMPESINATO, AGRICULTURA FAMILIAR E AGRONEGÓCIO

mando-se os critérios de renda e nível de escolaridade concluímos que o consumo de orgânicos ocorre de forma precisamente determinada pelas condições materiais. $\mathrm{O}$ envolvimento com a pesquisa conseguiu colher dados necessários à comprovação da natureza um tanto elitista do consumo.

Isto materializa-se na faixa de renda dos sujeitos. Cerca de $35 \%$ estão na faixa dos que recebem entre 2 e 5 salários mínimos. Quando se soma os que possuem uma renda mensal superior a 5 salários mínimos, esse número sobe para quase $60 \%$. A concretização de uma alimentação saudável envolve um privilégio, obedecendo a critérios como renda e nível de escolaridade.

Assim, a produção objetivada pelo campesinato, organizado na ASPOAGRE, no município de Itabaiana, possui no consumo condições subjetivas e que é, portanto, elitizado, especialmente num período em que a fome aumenta no país. E o acréscimo de valor no preço dos produtos evidencia isto. Ressalta-se mais uma vez que o valor mais alto não se dá pelo custo na produção, e sim pela pouca produção existente. Este fato não é diferente no resto do país, uma vez que as populações mais pobres, em sua maioria, não podem escolher qual comida irá consumir, pois seu consumo é regulado pelas relações sociais de produção das quais estão inseridos.

\section{CONCLUSÃO}

Compreendemos que o agronegócio enquanto movimento articulado de capitais, tem, no caso brasileiro, uma relação que envolve terra e Estado, formando uma tríplice aliança. No que tange à classe camponesa, a mesma segue resistindo das mais variadas formas para se reproduzir socialmente, caso dos agricultores organizados na ASPOAGRE. Para produção de alimentos, a luta dos camponeses vem se dando no campo de práticas próximas a agroecologia, que envolvem uma relação simbiótica com a natureza, em oposição ao parasitismo.

A Agricultura orgânica é uma das alternativas para uma alimentação saudável, e um equilíbrio ecológico necessário. Mas é preciso ir mais além. É pre- 
ciso fazer a crítica radical, no sentido de ir a raiz, à base material em que está assentada a sociedade brasileira. É preciso envolver na produção de alimentos saudáveis a democratização do acesso à terra.

Assim, a produção de orgânicos é um tanto escassa, visto as poucas condições de infraestrutura em que se encontra o campesinato. O Estado, que possui um recorte de classe muito específico, mostra sua função ao ausentar-se de forma bastante presente do aporte técnico aos produtores orgânicos. Nesse sentido, o consumo acaba sendo seletivo mesmo, pois a demanda envolve uma produção ínfima, comparada às toneladas de commodities produzidas pelo agronegócio todos os anos.

Evidentemente que o consumo seletivo não se dá apenas por isso. As condições de renda e nível de escolaridade, acabam sendo divisores de água para um consumo alternativo, pois a opção de comer orgânicos não passa pela mesa de todos brasileiros, mas sim daqueles que podem ter acesso a esses alimentos. Por isso, a necessidade de universalização dos produtos orgânicos, no âmbito da soberania alimentar, envolve os diferentes setores da sociedade.

E neste sentido, concluímos com a pesquisa que o consumo de orgânicos tem natureza contraditória, assim como as contradições presentes no capitalismo. $E$ que as contradições envolvem interesses determinados, ligados ao processo de reprodução desse modo de produção. As mesmas são explicitadas no acesso desigual aos produtos orgânicos e na própria opção pela produção deles.

Portanto, enfatizamos que, enquanto projeto de negação do agronegócio, potencializar a produção de orgânicos e democratizar o acesso à terra são meios para se chegar ao fim não só possível, como também necessário, de universalização de alimentos de qualidade, garantindo a reprodução da vida saudável para toda classe trabalhadora. 


\section{REFERENCIAS}

BORGES, Carlos Fragmon. Origens Históricas da propriedade da terra - 1958. In: STEDILE, João Pedro. (org.). A questão agrária no Brasil: o debate tradicional - 1500 - 1960. 2a ed. São Paulo: Expressão Popular, 2011. p. 259-291.

BRASIL. Em 7 anos, triplica o número de produtores orgânicos cadastrados no ministério. 2019. Disponível em: http://www.agricultura.gov.br/noticias/ em-sete-anos-triplica-o-numero-de-produtores-organicos-cadastrados-no-mapa. Acesso em: 29 outubro de 2019.

CAMPOS, Christiane Senhorinha Soares. A territorialização do agronegócio no Brasil. In: CAMPOS, C. S. S. A face feminina da pobreza em meio à riqueza do agronegócio: trabalho e pobreza das mulheres em territórios do agronegócio no Brasil: o caso de Cruz Alta/RS. $1^{a}$ ed. Buenos Aires: CLACSO, 2011. p. 101-132.

FERNANDES, Bernardo Mançano; WELCH, Clifford Andrew; GONÇALVES, Elienai Constantino. Os usos da terra no Brasil: debates sobre políticas fundiárias. $1^{\text {a }}$ ed. São Paulo: Cultura Acadêmica, 2014.

HESPANHOL, Antonio Nivaldo. Origem, magnitude e expansão territorial do agronegócio no Brasil. In: MEDEIROS, Rosa Maria Vieira; FALCADE, Ivanira (orgs.). Expressões da re-territorizalização do campo brasileiro. $1^{\text {a }}$ ed. Porto Alegre: Compasso Lugar-Cultura, 2013. p. 37-66.

LIMA, Lucas Gama. O processo de financeirização na agricultura: o perigo do agronegócio. In: Anais do XXIII Encontro Nacional de Geografia Agrária. São Cristóvão, 2016, p. 23-44.

MATOS, Alan Kardec Veloso de. Revolução verde, biotecnologia e tecnologias alternativas. In: Revista Cadernos da FUCAMP, Monte Carmelo/MG, 2010, v. 10, n. 12, p. 1-17, 2010.

NETTO, José Paulo; BRAZ, Marcelo. Economia política: uma introdução crítica. $8^{a}$ ed. São Paulo: Cortez, 2012.

OLIVEIRA, Ariovaldo Umbelino de. A mundialização da agricultura brasileira. $1^{\text {a }}$ ed. São Paulo: lãnde Editorial, 2016. ISBN 978-85-7506-145-9. 
ORGANIS. Panorama do consumo de orgânicos no Brasil 2019. Disponível em: http://organis.org.br/pesquisa-consumidor-organico-2019/. Acesso em: 29 outubro de 2019.

PINA, Rute. Previdência: governo propões reforma, mas quer perdoar dívida bilionária de ruralistas: Bolsonaro vai retomar projeto de 2017 que anistia $R \$ 17$ bilhões de sonegações de empresários rurais com o Funrural. Brasil de Fato: uma visão popular do Brasil e do mundo, São Paulo, 12 abr. 2019. Disponível em: https://www.brasildefato.com.br/2019/04/12/previdencia-governo-propoe-reforma-mas-quer-perdoar-divida-bilionaria-de-ruralistas/. Acesso em: 29 out. 2019.

PORTO-GONÇALVES, Carlos Walter. A globalização da natureza e a natureza da globalização. Rio de Janeiro: Civilização Brasileira, 2011.

ROSA, Fernanda Lima; SERGIO, Marleide Maria Santos. A realidade da produção orgânica em Areia Banca-se: desafio para o campesinato. In: Anais do XXIII Encontro Nacional de Geografia Agrária. São Cristóvão, 2016, p. 44-62. 


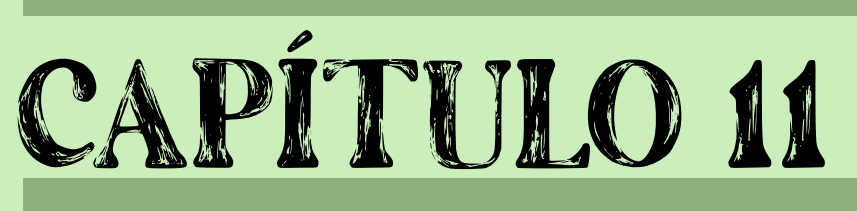

\section{TRANSFORMANDO A TERRA} EM HORTA ESCOLAR: A APLICAÇÃO DOS SABERES DOS JOVENS DO CAMPO NA ESCOLA ESTADUAL JOSÉ DE MATOS TELES EM JAPARATUBA - SERGIPE

Handresha da Rocha Santos Hádrian George da Rocha Santos 


\section{INTRODUÇÃO}

Percebendo que a Geografia no ensino médio tem um papel importante na construção de referências para os alunos, é preciso repensar de que maneira o profissional ensina essa disciplina. Esse profissional deve compreender que a escola deve ser um lugar de encontro e confronto entre as diferentes formas de concepções e práticas cotidianas e científicas. Assim, é possível pensar uma educação próxima à realidade dos alunos e, mais importante, pensar uma educação politizada, sem esquecer a experiência social, a formação, as crenças, a cultura e as opiniões políticas no processo educativo.

Justifica-se a importância desse artigo como meio para disseminação de conectividade da disciplina geografia, cotidiano escolar e de vida. É importante destacar que todo o conhecimento científico possui conexão com as vivências de um ser, basta apenas interligar essas informações, partindo da realidade vivida por essas pessoas. Despertar o interesse de crianças, jovens e adolescentes para o conhecimento empírico não é uma tarefa fácil, principalmente com as novidades tecnológicas que insistem em tirar a atenção deles.

Assim, destaca-se a necessidade da elaboração e desenvolvimento da atividade pedagógica horta escolar como complementação curricular, pois a implantação dessa na escola torna se um espaço educador sustentável e estimula a incorporação, percepção e a valorização da dimensão educativa a partir do meio ambiente.

A horta escolar se insere também como atividade produtora de aprendizagens múltiplas e significativas buscando através de metodologias diferenciadas despertar nos educandos o interesse pelo conhecimento, bem como uma melhor interação do aluno com a disciplina em sala de aula e a comunidade, potencializando as aprendizagens significativas.

Portanto, o artigo aborda a criação e implementação da horta escolar explorando a produção de produtos primários, produção e uso de adubo orgânico, se valendo da tecnologia de produção orgânica e sustentável sendo utilizado na 
complementação da merenda escolar, fornecendo subsídios para a implantação de hortas nas residências dos educandos, melhorando a qualidade da alimentação e o respeito ao meio ambiente. Por meio da iniciativa dos alunos do campo que estudam no Colégio Estadual José de Matos Teles localizado no município de Japaratuba no estado de Sergipe.

O objetivo desse texto, é mostrar a importância de como atividades integradoras a exemplo da horta escolar pode despertar o pensamento crítico no aluno para que ele se reconheça enquanto parte do meio ambiente, e também por isso, sendo necessário respeitá lo e preservá-lo. Bem como, salientar a relevância da produção de alimentos orgânicos que promova uma maior qualidade de vida e a discussão sobre expandir hortas nas casas dos alunos a partir dos conhecimentos e práticas realizadas na escola.

\section{CONTRIBUIÇÕES PARA UMA ALIMENTAÇÃO SAUdÁVEL E PRESERVAÇÃO AO MEIO AMBIENTE}

Este artigo apresenta a importância da horta na escola e suas contribuições para o desenvolvimento do hábito da alimentação saudável e a sensibilização para preservação e respeito ao meio ambiente com os alunos do Colégio Estadual José de Matos Teles. Portanto, foi desenvolvido o projeto "Horta na Escola" com o objetivo de promover a interação entre escola, familiares e a comunidade local através atividades pedagógicas interdisciplinares envolvendo a todos de forma interativa e prazerosa.

A horta foi implantada ao lado da escola, nas áreas que ficavam abandonadas, trazendo vários transtornos para o interior da escola como: mosquitos, ratos, baratas algo que incomodava a todos os alunos e funcionários. Esse artigo também aborda uma construção de práticas escolares no qual, a equipe escolar se empenhou em buscar soluções para mudar essa realidade. Esse projeto envolveu alunos, as famílias e a comunidade impactando a todos com mudanças de hábitos alimentares saudáveis e o despertamento de um novo olhar para os problemas de devastação do meio ambiente. 
Os impactos das ações humanas sobre o meio ambiente, afetando os ecossistemas e pondo em cheque o bem estar e a segurança das gerações futuras motivou pesquisadores e políticos ao redor do mundo à promover debates acerca da sustentabilidade, demandando um sistema de desenvolvimento que tivesse respaldo social, ambiental e econômico. As conferências e os relatórios internacionais do Meio Ambiente, entre elas a Declaração de Estocolmo, o Relatório Brundtland, a Conferência das Nações Unidas sobre Meio Ambiente e Desenvolvimento (Eco 92), a Declaração de Johanesburgo e a Conferência das Nações Unidas sobre Desenvolvimento Sustentável (Rio+20), contribuíram significativamente para a promoção e difusão dos debates internacionais acerca da sustentabilidade e as medidas viabilizadoras deste processo.

As Conferências Internacionais sobre o Meio Ambiente surgiram, inicialmente, através da preocupação dos países desenvolvidos em rever seu modelo de produção, e buscar alternativas econômicas para se alcançar uma harmonização com o meio ambiente.

Jacobi (2003) aborda a questão da produção do conhecimento e o papel dos diversos atores na perspectiva de um desenvolvimento menos desigual.

A produção de conhecimento deve necessariamente contemplar as inter-relações do meio natural com o social, incluindo a análise dos determinantes do processo, o papel dos diversos atores envolvidos e as formas de organização social que aumentam o poder das ações alternativas de um novo desenvolvimento, numa perspectiva que priorize novo perfil de desenvolvimento, com ênfase na sustentabilidade socioambiental. (JACOBI, 2003, p. 190).

Com o passar do tempo, o entendimento de que o subdesenvolvimento estava no cerne da problemática ambiental, o enfoque e a abordagem das Conferências foram se transformando, passando a valorizar novos meios de difusão socioambiental, ampliando as responsabilidades ao redor do globo, inserindo novos conceitos, diretrizes e acordos no cenário internacional que passou a vislumbrar a criação de um Regime Internacional Ambiental. 
De acordo com o relatório O Futuro que Queremos (2012), é essencial que a economia verde seja implementada globalmente, em acordo com as declarações finais das demais conferencias mundiais sobre os aspectos fundamentos do desenvolvimento sustentável (econômico, social e ambiental), convergindo esforços internacionais para consolidar um desenvolvimento sustentável e equitativo em todo mundo (BRASIL, 2012).

Dessa forma, pensando na educação ambiental como parte essencial de educação de todos os cidadãos e na escola como um espaço de interação, socialização, aprendizagem atrativa e inclusiva foi desenvolvido o projeto Horta escolar, contemplando em suas atividades pedagógicas interdisciplinares os temas meio ambiente, saúde e alimentação saudável, levando os alunos a participarem de forma prazerosa das atividades que levam a sensibilização sobre a importância do cuidado e respeito ao meio ambiente.

O objetivo principal do projeto foi apresentar a realidade atual e estimular o hábito da alimentação saudável e promoção da saúde por meio de atividades lúdicas como músicas, e a prática ou seja construção da horta, nas instituições de ensino, além disso, mostrando as mudanças nos hábitos alimentares, a importância da alimentação saudável e os perigos da utilização dos agrotóxicos tanto para a saúde como para o meio ambiente, proporcionando aos jovens o senso de responsabilidade de seu dia a dia, com valores e compromissos estabelecendo relações saudáveis com a meio ambiente tomando para si a consciência da necessidade do respeito, do cuidado e da preservação.

Nesse contexto Freire, (2000, p. 66-67) diz:

"Nosso compromisso, enquanto cidadão nesta sociedade globalizada é o de uma visão mais clara e ampla com a qualidade ambiental para um presente e futuro próximo, onde o homem terá oportunidade a sua vez e voz, tendo como vista não o espaço próximo de ação, mas também o horizonte planetário."

Assim, sabe-se que a Lei $n^{\circ}$. 9.394/96 (LDB), orienta para o enriquecimento e formulação de propostas educacionais, a inclusão de estudos relacionados 
ao desenvolvimento socioeconômico, ambiental e regional. Se o ato de ensinar traz como consequência o aprendizado, muito provavelmente a educação ambiental, se inserida nos níveis educacionais, traria mudanças de fato, no estilo de vida e conscientizaria socialmente os educandos.

Inquestionalmente, a importância da educação ambiental e o esclarecimento sobre as leis ambientais é a base inicial de toda a formação ambiental, onde o educando deve ser preparado para administrar os problemas ambientais.

A educação ambiental não se preocupa apenas com a aquisição de conhecimento, mas também, fundamentalmente, visa possibilitar um processo de mudança de comportamento e aquisição de novos valores e conceitos convergentes às necessidades do mundo atual, com as inter-relações e interdependências que se estabelecem entre o ambiente social, cultural, econômico, psicológico, humano.

Destarte, faz-se necessário incorporar a dimensão ambiental da educação no currículo escolar por ser de fundamental importância à sua atualização, modernização e realidade local, bem como trabalhar a educação ambiental, de forma a utilizar-se do conhecimento popular para o resgate de bases fortes do meio ambiente equilibrado, para a conservação e manutenção desse.

\section{MATERIAIS E MÉTODOS}

O projeto teve início em Abril de 2019 nas dependências do Colégio Estadual José de Matos Teles, com duas turmas do terceiro ano do ensino médio (3B e 3C). Iniciando se com aulas teóricas, aliadas ao reconhecimento da área disponível para plantio. Após estudo iniciou se a preparação da Terra com limpeza de terreno, adubação, forragem e demarcação. Na sequência foi feito o plantio e os cuidados com as culturas desenvolvidas. Na fase da colheita os produtos serão incrementados a merenda escolar e o excedente se houver, será dividido entre os alunos para o incremento da alimentação em casa.

A metodologia utilizada foi a atividade experimental que propicia o resga- 
te dos saberes dos alunos, em relação ao conteúdo que se pretende trabalhar, constituindo-se o ponto de partida para o processo de ensino/aprendizagem. Assim, foi proposto que através da investigação e a divulgação científica os conteúdos desenvolvidos sejam encaminhados por meio de uma metodologia crítica e histórica, de modo a articular os conhecimentos práticos (campo), através de pesquisas bibliográficas, leitura de artigos e textos científicos, realização de experimentos, CD ROM, softwares educativos e sites da internet. Os estudos culminaram na implantação e na manutenção da horta mantendo-a em constante produção, abastecendo a cozinha da escola para incrementação da merenda e o excedente rateado entre os alunos participantes.

Diante dos objetivos propostos, optou-se também por um resgate do estudo das conferências ambientais, uso do solo sob forma bibliográfica e empírica considerando ser a mais apropriada à realização deste trabalho. Para tanto, realizou-se uma revisão teórica em artigos, livros, textos complementares sobre a complexidade do assunto em questão. Também foram coletadas informações diante de questionários e relatos dos atores sociais para que corroborassem com os resultados do projeto.

O projeto horta na escola foi desenvolvido pelos alunos do PIBID (programa institucional de bolsa de iniciação à docência) da educação á distância do curso de geografia da Universidade Federal de Sergipe, com suporte pedagógico das supervisoras PIBID, no Colégio Estadual José de Matos teles em Japaratuba, juntamente com a equipe de professores dos turnos matutino e vespertino. Contudo, foi utilizado o terreno da escola que era esquecido e depósito de ervas daninhas.

O sonho da horta escolar iniciou se a partir da reunião com a coordenadora PIBID a qual, pediu para realizar um projeto maior que onde pudéssemos aplicar os conhecimentos teóricos e práticos da geografia, a partir daí realizou-se uma reunião com os estagiários do PIBID e com as comunidades escolares para apresentar o projeto e informar sobre os benefícios da horta para a saúde, escola e ao meio ambiente. Com a aprovação foi iniciado as atividades de limpeza do ter- 
A QUESTÃO AGRÁRIA NO BRASIL: CAMPESINATO, AGRICULTURA FAMILIAR E AGRONEGÓCIO

reno e todas as turmas onde estão sendo desenvolvidas as atividades do PIBID prontamente se propuseram ajudar a retirar o lixo do local de plantio, e participar cuidando e preservando.

Assim, foi realizada a construção dos canteiros, é necessário ressaltar o suporte e auxílio que os técnicos agrícolas da prefeitura municipal ou EMDAGRO (Empresa de desenvolvimento agropecuário de Sergipe) realizaram, orientando sobre as formas corretas de plantio, adubos orgânicos, cuidados e o manejo correto, facilidade de plantio, a resistência às "pragas", e os aspectos que influenciam no desenvolvimento das plantas. Os materiais para implantação da horta escolar foi doado pela prefeitura municiapal de Japaratuba, como sementes e estercos e também doados pelas famílias dos alunos.

A proposta destaca a inserção da educação ambiental por meio da implantação da horta, pela qual pode-se trabalhar alternativas de manejo de solo-água, a importância das hortaliças na alimentação, técnicas de produção, o trabalho cooperado e participativo, e a reciclagem- pois alguns canteiros forram confeccionados com garrafas pet.

Cabe ressaltar, que antes da implantação da horta os alunos tiveram a oportunidade de discutir a educação ambiental e como esta poderia contribuir para o desenvolvimento de uma sociedade, realizaram pesquisas sobre hortaliças, recursos hídricos, solo e técnicas de manejo.

Finalizada as pesquisas e discussões que antecedem a implantação da horta os educandos partiram para a intervenção e confecção dos canteiros iniciando com a escolha da área para introdução do projeto, em seguida realizaram a limpeza da área e marcação dos canteiros e, posteriormente, realizaram em grupo uma catação de garrafas pets para confecciona-los.

No primeiro ciclo de produção foram plantados coentro, cebolinha, tomate, pimenta de cheiro e cebola . No sentido de demonstrar alternativas de controle de pragas que venham a prejudicar o desenvolvimento das culturas, fez se uso de algumas técnicas de manejo como uso do adubo natural NPK (casca de banana, ovos, borra de café e água), rico em cálcio, magnésio e fósforo. 


\section{RESULTADOS E DISCUSSÕES}

Com a implantação da horta na escola os educandos tiveram a possibilidade de realizar pesquisas em diversas áreas do conhecimento, pois este espaço pode ser considerado um laboratório a céu aberto, contribuindo para estimular os alunos a realizar pesquisas científicas e para promoção de um ensino de qualidade dentro do ambiente escolar.

As imagens abaixo mostram o processo de implantação do projeto " Horta escolar", no qual todo o conhecimento e vivência dos alunos que residem no campo, filhos de agricultores puderam ser aplicados num laboratóio a céu aberto ,partilhando com os jovens residentes no ambiente urbano saberes e técnicas milenares. Destarte, é pertinente afirmar que a proposta inicial de trocas de conhecimentos entte os jovens,conscientização ambiental e alimentar e aproveitamento de espaços para produção orgânica de alimentos saudáveis foi alcançada.

\section{Aspectos da Horta escolar no Colégio Estadual José de Matos Teles}

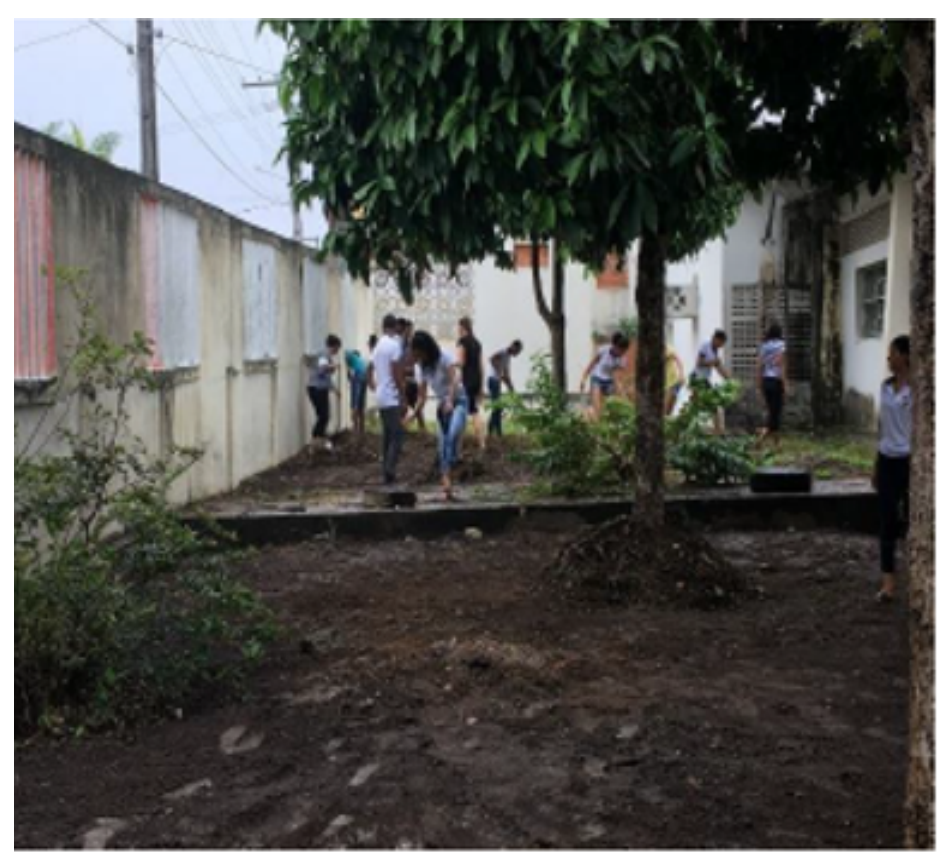

Imagem 1: Limpeza do local

Fonte: Handresha Rocha 2019

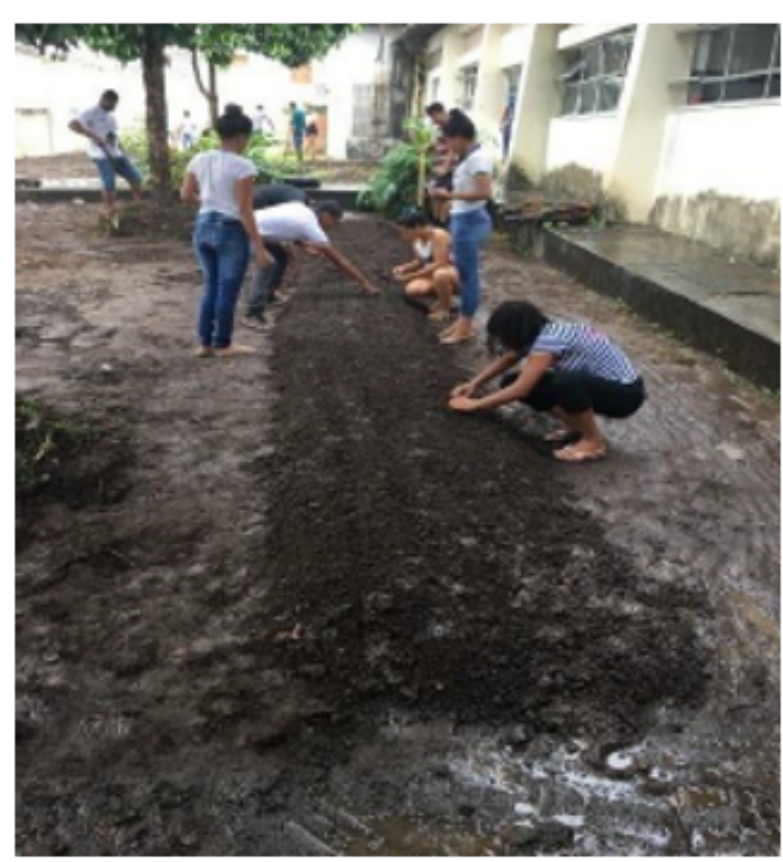

Imagem 2: Construção dos canteiros

Fonte: Handresha Rocha 2019 


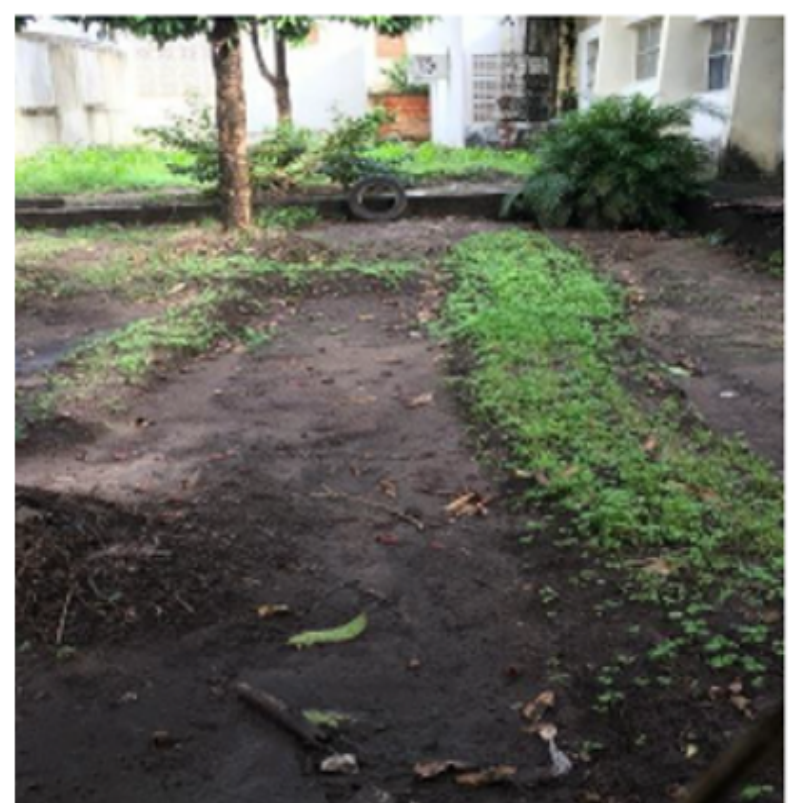

Imagem 3: Crescimento das hortaliças

Fonte: Handresha Rocha 2019

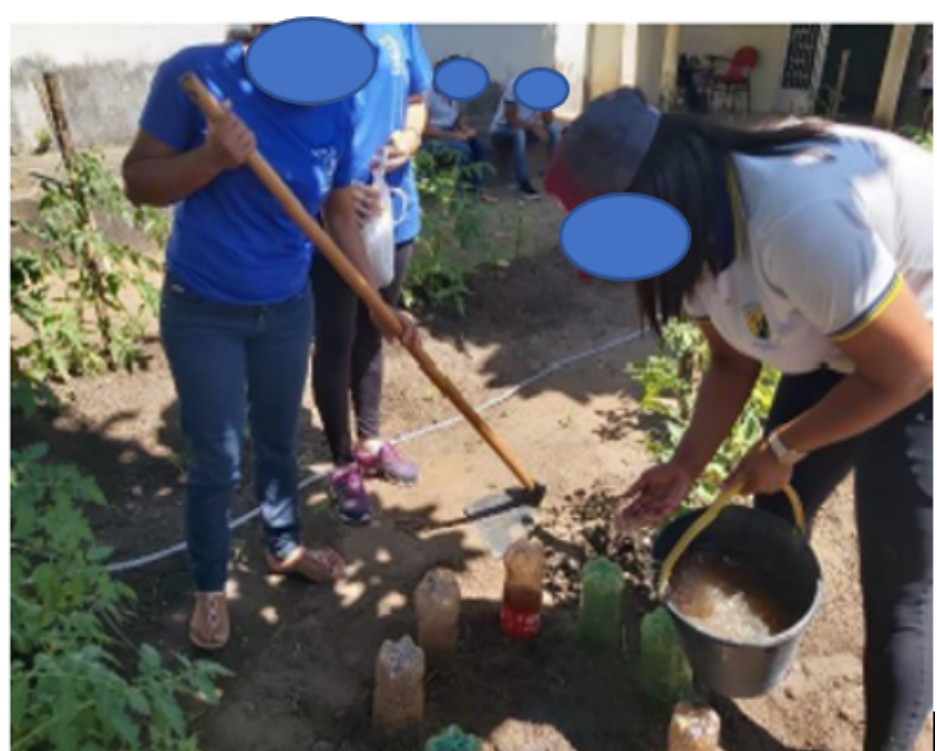

Imagem 4: Canteiros feitos com garrafas Pets Fonte: Handresha Rocha 2019

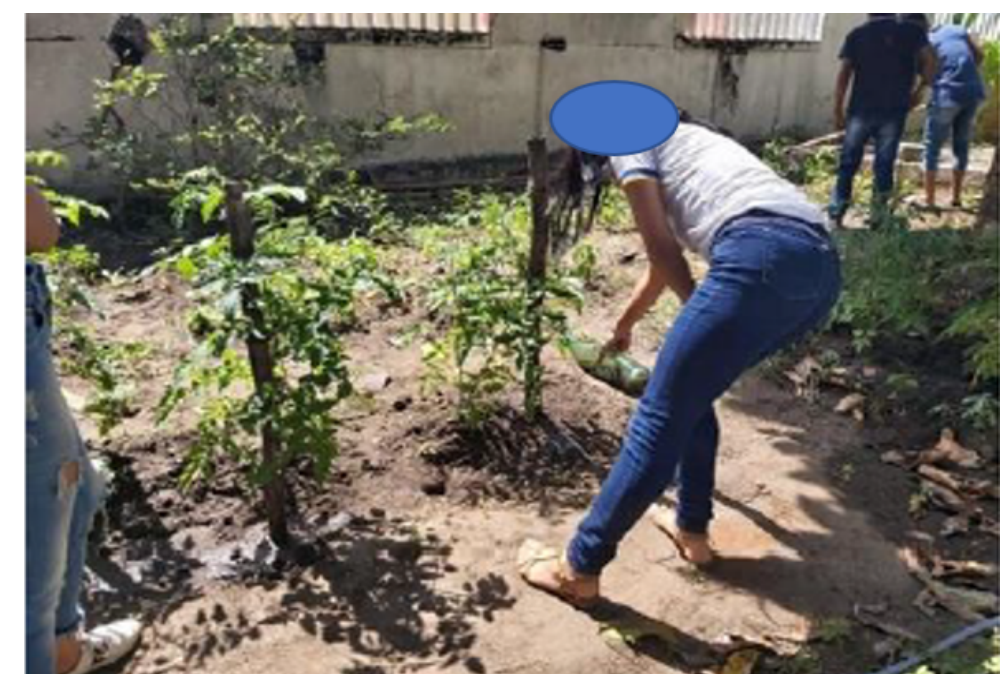

Imagem 5: Uso do adubo NPK orgânico

Fonte: Handresha Rocha 2019

Posteriormente, foi aplicado questionários com os alunos envolvidos no projeto para diagnosticar a efetividade desse, com relação aos resultados os alunos afirmaram que aprenderam a ter uma maior sensibilidade para com as questões ambientais e também com a segurança alimentar. Como também foi importante para melhoria do trabalho coletivo e participativo entre os mesmos, sendo a escola um ambiente privilegiado para se discutir atividades á essas questões. 


\section{CONCLUSÃO}

Destarte, pensando na educação ambiental como parte essencial de educação de todos os cidadãos e na escola como um espaço de interação, socialização, aprendizagem atrativa e inclusiva foi desenvolvido o projeto Horta escolar, contemplando em suas atividades pedagógicas interdisciplinares os temas meio ambiente, saúde e alimentação saudável, levando os alunos a participarem de forma prazerosa das atividades que levam a sensibilização sobre a importância do cuidado e respeito ao meio ambiente. Respeitando o modo de vida dos alunos que são jovens do campo, filhos de agricultores familiares onde puderam dividir seus conhecimentos com a comunidade escolar do Colégio estadual José de Matos Teles.

O objetivo principal do projeto foi apresentar a realidade atual e estimular o hábito da alimentação saudável e promoção da saúde por meio de atividades lúdicas como a prática ou seja construção da horta, na instituição de ensino, além disso, mostrando as mudanças nos hábitos alimentares, a importância da alimentação saudável e os perigos da utilização dos agrotóxicos tanto para a saúde como para o meio ambiente, proporcionando aos jovens o senso de responsabilidade de seu dia a dia, com valores e compromissos estabelecendo relações saudáveis com a meio ambiente tomando para si a consciência da necessidade do respeito, do cuidado e da preservação.

\section{REFERENCIAS}

BARBOSA, Najla Veloso Sampaio A horta escolar - Dinamizando o currículo daescola. FNDE,2017

BRASIL. MINISTÉRIO DO MEIO AMBIENTE. Agenda 21 Brasileira: Resultado daConsulta Nacional. 2004. Disponível em: . Acessado em Agosto 2019.

Alimentação e nutrição: Caminhos para uma vida saudável. FNDE,2017 
CALLAI, Helena Copetti. A Geografia ensinada: Os desafios de uma educação geográfica. Formação de professores: conteúdos e metodologias no ensino de geografia. 1ed.Goiânia: Editora Vieira, 2010.

CASTELLAR, S.M.V. A formação de professores e o ensino da geografia. As transformações no mundo da educação, Geografia, Ensino e responsabilidade social,1999, AGB, Terra livre (pág 51-59)

JACOBI, P. Educação ambiental, cidadania e sustentabilidade. Cadernos de pesquisa,v.118. n. 3, p. 189-205, 2003.

FERNANDES, Maria do Carmo Araújo Orientações para implantação da horta escolar. FNDE2017

FREIRE, Paulo. Pedagogia da indignação. São Paulo: Editora UNESP, 2000.

Lei de Diretrizes e Bases da Educação Nacional - Planalto www.planalto.gov. br >ccivil_03 > LEIS Acessado em agosto de 2019

LEFF, E. Saber Ambiental: sustentabilidade, racionalidade, complexidade, poder.Petrópolis: Vozes, 2001.

PONTUSCHKA, N.N; PAGANELLI, T.I; CACETE, N.H. Para ensinar e aprender Geografia. Cortez Editora, 2007. 
dol 10.48209/978-QR-89949-12-6

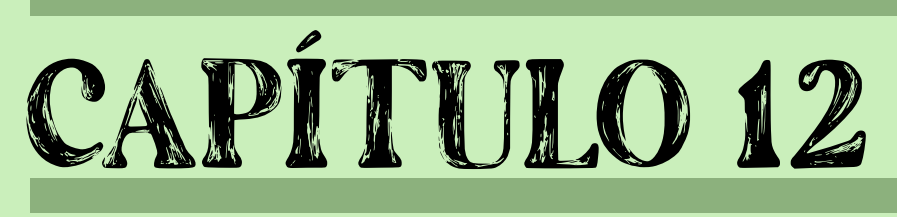

\section{TERRAS DEVOLUTAS E} DISCRICIONARIEDADE ADMINISTRATIVA: ANÁLISE CRÍTICA DA SUPREMACIA DO INTERESSE PÚBLICO SOBRE O PRIVADO A LUZ DO CONSTITUCIONALISMO CONTEMPORÂNEO

Walder Araújo de Oliveira 


\section{INTRODUÇÃO}

No Brasil, as ocupações de terras públicas, em particular as devolutas, foram historicamente reconhecidas como posse, mas no transcorrer dos séculos esse reconhecimento foi questionado e restringido, seja pela previsão normativa ou pelo entendimento doutrinário e jurisprudencial. Atualmente, apesar das controvérsias dos tribunais superiores, há o posicionamento firmado de não haver a posse de terras públicas, mas sim detenção, por ato de mera permissão ou tolerância do poder público.

O instituto da detenção, tratado no vigente código civil brasileiro, constitui a relação material do sujeito com o bem, que possui os mesmos elementos da posse (corpus e animus), mas se diferencia desta à medida que a lei retira da detenção os seus efeitos, quais sejam: os interditos possessórios, o direito de retenção e indenização pelas benfeitorias construídas, bem como a aquisição da propriedade através da usucapião. Ao detentor é permitido apenas o uso do desforço imediato, que consiste no direito de autoproteção da posse, exercida em nome do possuidor ou proprietário. Todavia, a negativa da posse, centra-se nas disposições constitucionais, que tratam da vedação à usucapião de terras públicas, implicando na proibição dos efeitos da posse para as ocupações de terras públicas.

Por outro lado, o Estado moderno, foi instituído em um ambiente de afirmações de valores individuais, que influencia tanto o espaço privado, como também o espaço público. Desta forma, o interesse público passou a assumir uma postura intervencionista, haja vista, que a satisfação dos interesses coletivos, desenvolve-se com a doutrina do princípio da supremacia do interesse público sobre o privado. Tal princípio merece uma análise crítica, já que na atual ordem constitucional, o mesmo se apresenta com status de supremacia na atuação direta, imediata e concreta da administração pública, devendo assegurar a efetivação dos direitos e garantias fundamentais. 
A QUESTÃO AGRÁRIA NO BRASIL: CAMPESINATO, AGRICULTURA FAMILIAR E AGRONEGÓCIO

O Estado democrático de direito, deve pautar-se, pela busca da satisfação dos interesses públicos, condizentes com a vontade da coletividade. Diante desse entendimento, questiona-se a sua aplicabilidade, para as ocupações rurais de terras devolutas agroextrativistas, sobre tudo, diante da diversidade social e fundiária brasileira. Propomos responder o seguinte questionamento: será que de fato a posse de terras devolutas, foi efetivamente vedada aos territórios de comunidades agroextrativistas, tendo em vista, há aplicabilidade da convenção 169 da OIT, com as ocupações de povos tradicionais quilombolas, no atual contexto contemporâneo?

Seu objetivo geral é analisar a decisão proferida no TRF4a ${ }^{a}$, que reconheceu a aplicação da Convenção 169 da OIT, para os quilombolas no Agravo de Instrumento 200804.00.010160-5/PR do Relator Desembargadora Maria Lúcia Luz Leira, julgado em 01/07/2008, analisar a decisão do STF que julgou improcedente a ADI 3.239, proferida pelo Relator Ministro Cezar Peluso em 08.02.2018, admitindo a aplicação da Convenção 169 da OIT, para os quilombolas. E ainda, analisar a Apelação Cível 70081566853/RS do Relator Gelson Rolim Stocker, julgado em 22/08/2019 pela $17^{\text {a }}$ Câmara Cível e Publicado em 09/09/2019, sobre usucapião de terras devolutas, proferida pelo TJRS.

A metodologia utilizada fora feita, por meio de estudo de casos, através de legislações e jurisprudências, com a temática de ocupação de terras devolutas. Pesquisa bibliográfica, doutrinária, com ênfase em artigos científicos, proporcionando uma análise qualitativa e descritiva. Dentre os principais resultados alcançados deste estudo, temos a decisão do STF que julgou improcedente a ADI 3.239, reconhecendo a aplicação da convenção 169 da OIT, para as comunidades quilombolas e a decisão da $17^{\text {a }}$ câmara cível em apelação cível 70081566853/RS do TJRS, onde o Estado do Rio Grande do Sul, questionava arbitrariamente a (in) suscetibilidade da prescrição aquisitiva, considerando tais terras como devolutas. 


\section{O PRINCÍPIO DA SUPREMACIA DO INTERESSE PÚBLICO NO CONTEXTO CONTEMPORÂNEO}

O direito administrativo, como os demais ramos do direito, sofreu uma profunda mutação em seus alicerces teóricos, devido a uma crescente complexidade das relações humanas. A princípio, entendia-se como fundamento do direito administrativo a noção de serviço público. Tal construção teórica deve-se à doutrina francesa de León Duguit, denominado de pai da escola do serviço público, aglutinando em torno de toda a estrutura do direito administrativo, que passou a ser conceituado, como o conjunto de regras aplicadas ao funcionamento dos serviços públicos, sendo responsável por organizar um estado de direito prestacional (GABARDO, 2017), colocando o serviço público, como fundamento do direito público. Por sua vez, Aragão (2017) ao comentar a teoria de León Duguit, afirma que:

[...] É o estado de consciência da massa dos indivíduos que compõem em um determinado grupo social a força criadora do direito, que eclode quando o grupo social entende e admite que possa ser socialmente organizada uma reação contra os violadores da regra, momento em que a simples norma social, fundada sobre a solidariedade e interdependência dos indivíduos que compõe a sociedade, se transforma em norma jurídi$\mathrm{ca}$, que é originariamente um fato social, não uma criação do estado ou expressão da sua soberania. Essas normas se impõem objetivamente ao estado, assim como a todos os indivíduos (ARAGÃO, 2017, p. 82).

A atual constituição tratou da propriedade urbana e rural, pública e privada, estabelecendo diretrizes, que passaram a guiar as normas infraconstitucionais, editadas antes de sua promulgação. Embora a propriedade esteja definida na legislação civil. É importante frisar que, esta garantia constitucional abrange não apenas os bens imóveis e móveis, mas outros valores. Estes valores podem ser descritos como, "direito fundamental a moradia, dignidade da pessoa humana e a valorização do trabalho", todos consubstanciados na magna carta (MENDES e BRANCO, 2020).

Antes o sistema jurídico nacional, estabelecia duas principais formas de reconhecimento da propriedade particular sobre terras públicas, em especial as 
devolutas. A primeira seria "por ato administrativo do poder público" e a segunda seria "por iniciativa do particular", que poderia levar a usucapião. Compreende-se que "[...] a propriedade privada no Brasil originou-se por duas vias distintas: I por ato do Poder Público, por via das sesmarias, concessões, cessões ou venda; II - por ato ou iniciativa do próprio particular, com a ocupação ou a posse da terra e dos recursos naturais, amparado ou não por um título" (BENATTI, 2003). Estes títulos, geralmente, estão com o segundo ocupante, que os adquiriram, através de compra e venda ou partilha dos primeiros ocupantes de terras devolutas, para a construção de suas benfeitorias, titularizadas sem o devido aval governamental.

Diante dessas duas vias, uma vez não reconhecida à posse de terras por ato do Poder público, o particular pode utilizar-se da via judicial, para este reconhecimento, através da ação de usucapião, caso preenchidos os requisitos legais. Assim, duas correntes surgiram a partir da interpretação do presente art. 67 do CC de 1916, que possuía a seguinte redação: Os bens de que trata o artigo antecedente só perderão a inalienabilidade, que lhes é particular, nos casos e forma que a lei prescrever. A primeira corrente entende que a prescrição aquisitiva estava vedada, sob o fundamento de que ao proclamar a inalienabilidade dos bens públicos, estava também, prevendo a imprescritibilidade, à medida que condicionava a alienação a uma lei específica que não tinha sido editada. A segunda corrente, em sentido contrário, propugnava que o código civil não dispunha nada de novo a respeito da prescrição dos bens públicos, de modo que permaneciam em vigor os princípios, até então adotados para o Direito Público (BARRETO, 2019).

Desta forma, surge a possibilidade de usucapir terras públicas, o que se daria no caso de bens dominicais, pois tal dispositivo, teria se referido à inalienabilidade dos bens públicos de uso comum e aos especiais. Por outro lado, não podemos nos esquecer, que graças ao plano nacional de reforma agrária, entre outros aspectos, a atuação contemporânea estatal, visa garantir o acesso aos trabalhadores rurais às terras disponíveis, com garantia de permanência e 
desenvolvimento da atividade agrária, sempre priorizando a alienação e a concessão, fazendo menção a aplicabilidade do princípio da privatização das terras públicas (OLIVEIRA, 2015).

Todavia, os mecanismos para a garantia da habitação ao trabalhador rural, está prevista no art. 187, inciso VIII, $\S 2^{\circ}$ da CF/88, que visa dentre outros aspectos, assegurar a cidadania, a dignidade da pessoa humana, os valores sociais do trabalhador, na busca de construir uma sociedade mais justa, reduzindo a pobreza e as desigualdades sociais. Por sua vez, Di Pietro, nos esclarece que:

[...] O Direito Administrativo nasceu e desenvolveu-se baseado em duas ideias opostas: de um lado, a proteção aos direitos individuais frente ao Estado, que serve de fundamento ao princípio da legalidade, um dos esteios do Estado de Direito; de outro lado, a de necessidade de satisfação dos interesses coletivos, que conduz à outorga de prerrogativas e privilégios para a Administração Pública, quer para limitar o exercício dos direitos individuais em benefício do bem-estar coletivo. [...]

Ao mesmo tempo em que as prerrogativas colocam a Administração Pública em posição de supremacia perante o particular, sempre com objetivo de atingir o benefício da coletividade, as restrições a que está sujeita limitam a sua atividade a determinados fins e princípios que, se não observados, implicam desvio de poder e consequentemente nulidade dos atos da Administração (DI PIETRO, 2020, p. 223).

Portanto, muito se crítica no que diz a respeito, há contradição latente no Direito Administrativo, concebido como provedor da defesa do indivíduo contra o Estado, mas que no presente momento, se apresenta como princípio fundamental, supremo e de interesse público, entretanto a ausência de tratamento crítico na doutrina administrativa tradicional vigente aponta uma das características do paradigma da supremacia do interesse público.

\section{INTERESSE PÚBLICO PRIMÁRIO E SECUNDÁRIO}

A doutrina de Direito Administrativo Brasileiro fora influenciada pelo Direito Italiano clássico, desta forma, ao analisarmos a supremacia jurídica, que goza a administração pública, percebe-se a grande necessidade de impor limites a sua soberania, através do interesse público primário e secundário (ALESSI, 1953). 
Ressalta ainda, que tais limites supramencionados, impõe a norma jurídica ao legitimar o comando administrativo a fim de oferecer, certa tutela aos indivíduos, contra a possibilidade de arbitramento e opressão por parte dos governantes. Outro limitador, seria a função administrativa, compreendida como encargo concretizador dos interesses públicos da coletividade (HACHEM, 2011). Sendo assim, os interesses primários decorrem da dimensão pública dos direitos dos indivíduos inseridos em um dado contexto social, enquanto que os interesses secundários de toda manifestação de vontade do Estado enquanto pessoa jurídica. Barroso apresenta relevante síntese, ao afirmar que:

O interesse público primário é a razão de ser do Estado e sintetiza-se nos fins que cabe a ele promover: justiça, segurança e bem-estar social. Estes são interesses de toda a sociedade. O interesse público secundário que seja parte da União, do Estado-membro, do Município ou das suas autarquias. Em ampla medida, pode ser identificado como o interesse do erário, que é o de maximizar a arrecadação e minimizar as despesas (BARROSO, 2005, p. 13).

No entanto, entende-se que tal posicionamento doutrinário, que considera o interesse público em primário e secundário, ensejou no Brasil, uma grande desvirtuação da incidência do princípio da supremacia da satisfação dos direitos e garantias fundamentais, constitucionalmente determinados em observância obrigatória por parte do Estado.

A formação social e política do Brasil fora marcada sobremaneira, por práticas coronelísticas e clientelistas, no que diz a respeito do trato da coisa pública, como propriedade privada do governante, que ainda é tão presente no exercício da política. Desta forma, o interesse secundário como interesse público é algo que, se utilizado de forma incoerente com os ditames legais que vinculam à Administração Pública, importará no exercício de autoritarismo (GABARDO, 2017).

Neste aspecto, os direitos fundamentais compreendem o atual constitucionalismo, que consagram o reconhecimento dos direitos inalienáveis dos indivíduos, para os direitos fundamentais, são considerados como núcleo de todo o constitucionalismo moderno, assim como os direitos do homem, que possuem 
uma estreita relação. De todo modo, os direitos do homem, possui como características os seguintes aspectos: são universais, fundamentais, preferenciais, abstratos e morais. Já os direitos fundamentais, por outro lado, são os direitos que foram acolhidos em uma constituição com o intuito de positivar os direitos do homem. A positivação mão anula os direitos do homem, mas confere validade jurídica a eles (ALEXY, 2003). Nesse sentido, Canotilho (2003) nos ensina que:

[...] A positivação de direitos fundamentais significa a incorporação na ordem jurídica positiva dos direitos considerados "naturais" e "inalienáveis" do indivíduo. Não basta qualquer positivação. É necessário assinalar-Ihes a dimensão de Fundamental Rights colocados no lugar cimeiro das fontes de direito: as normas constitucionais. Sem esta positivação jurídica, os direitos do homem são esperanças, aspirações, ideias, impulsos, ou até, por vezes, mera retórica política, mas não direitos protegidos sob a forma de normas (regras e princípios) de direito constitucional [...] (CANOTILHO, 2003, p. 327).

Desta forma, fica evidente a força vinculante, que os direitos e garantias fundamentais, exercem sobre toda atuação estatal e sobre todos os poderes do Estado, pois uma vez positivados no corpo constitucional, impõem a observância obrigatória, por todos os poderes, legislativo, judiciário e executivo. Em razão da superioridade, que as normas constitucionais, asseguradoras de direitos fundamentais, possuem em nosso ordenamento jurídico.

\section{TERRAS OCUPADAS PELAS POPULAÇÕES TRADICIONAIS E A POSSE AGROECOLÓGICA}

Dentre as populações tradicionais, tais como ribeirinhos, caboclos e remanescentes de quilombos, onde sua economia é fundamentada no agroextrativismo, sob a ótica jurídica e fundiária, podemos considera-los como "posseiros", quando não tiveram o seu direito à terra reconhecida, pois ocupam terras devolutas, sem consentimento de terceiro, consequentemente, não possuem títulos legais, que lhes garantam o domínio da terra, que estão de posse. Os únicos títulos que detêm, são o seu trabalho e as atividades agroextrativistas, que realizam na terra para dar sustento a si e às suas famílias. 
A QUESTÃO AGRÁRIA NO BRASIL: CAMPESINATO, AGRICULTURA FAMILIAR E AGRONEGÓCIO

Na posse agroecológica das populações tradicionais estão presentes todas as características da posse agrária ou da posse originária, previstas, respectivamente, na legislação agrária e no Código Civil, respeitando-se as particularidades do apossamento das populações tradicionais (BENATTI, 2003).

Quando valorizamos o trabalho na posse, como forma de adquirir a terra, estamos admitindo também que a atividade agrária (pecuária, agricultura, extrativismos vegetal e animal) tenha um valor econômico, pois o possuidor se dedica com a finalidade de suprir as suas necessidades e vender o excedente. Logo, a posse agroecológica segundo é essencialmente para as populações tradicionais, pois o uso e manejo dos recursos naturais, seja no seu aspecto de produção agroextrativista, sejam no uso racional dos recursos naturais (ROCHA, 2019).

É importante salutar ainda, que a posse agroecológica só pode ocorrer sobre um bem ou coisa, não sobre um direito, por se tratar de uma relação fática, ou seja, um fenômeno que se manifesta ostensivamente e que surge da relação social de atos possessórios agroambientais, que são exercidos sobre bens e não sobre direitos, a posse agroecológica não é um elemento factual puro, pois para ser considerada como tal, ela deverá ter, além do elemento econômico, um fim social, ou seja, também contribuir para a melhor distribuição do solo e dos recursos naturais renováveis. Ao mesmo tempo, respeitará o meio ambiente, utilizando-o de forma sustentável, segundo a posse pode ser transmitida por herança, venda ou qualquer outra causa e somente se perde quando deixa de existir a relação direta, imediata e agroambiental com a terra, possuem também elementos da composse, previsto no art. 1.119 do CC, em particular o uso dos recursos comuns dos quais podemos citar: o pasto, o lago, a caça e a coleta de produtos não madeireiros.

Por sua vez, as populações tradicionais em suas relações com solo e os recursos naturais podem ser divididos em três espaços ecológicos e sociais distintos, que estão interligados entre si, onde desenvolvem suas formas particulares de vida, todavia, a casa, a roça e a mata no espaço geográfico, estão incluídas também, os rios, igarapés, lagos e campos naturais. O Decreto $n^{\circ} 4.340$, de 22 de 
agosto de 2002, regulamenta os artigos da Lei n 9.985, de 18 de julho de 2000, que dispõe sobre o Sistema Nacional de Unidades de Conservação da Natureza (SNUC). Todavia, o presente art. 35 da mesma lei, trata do reassentamento das populações tradicionais e o processo indenizatório, sempre respeitando o modo de vida e as fontes de subsistência das populações tradicionais. Nesta perspectiva, a Lei 9.985 , de 18 de julho de 2000, define a compensação pelas benfeitorias construídas e devidamente realocadas pelo Poder Público no local acordados entre as partes (BRASIL, 2002).

Portanto, para o Código Civil Brasileiro o presente art. 96 da Lei 10.406, de 10 de janeiro de 2002, reforça o entendimento de que as benfeitorias, úteis e necessárias, são as culturas anuais e temporárias, as culturas perenes, as pastagens, os semoventes, as construções, os equipamentos, as ferragens e qualquer atividade humana que requeira trabalho objetivando a conservação da natureza. Da mesma forma, são consideradas benfeitorias na área da comunidade, a igreja, o campo de futebol, a casa de farinha, a sede da comunidade, a escola e o porto.

\section{DIREITO TERRITORIAL DAS POPULAÇÕES TRADICIONAIS}

A diversidade de reivindicação do reconhecimento das populações tradicionais acabou levando à elaboração de diversos procedimentos legais e administrativos de reconhecimento dos territórios das populações tradicionais, assim diversos órgãos foram criados ou reestruturados, como por exemplo, o INCRA, ICMBio e a FUNAI, para receberem e instrumentalizarem as demandas sociais, sob a influência dos direitos territoriais garantidos aos indígenas ${ }^{26}$ e quilombo$\operatorname{las}^{27}$, aliados aos movimentos ambientalistas, seringueiros lograram êxito com a criação das reservas extrativistas.

$\overline{26}$ O art. 231 da Constituição Federal de 1988 reconhece o direito originário indígena, sobre suas terras tradicionais ocupadas, competindo a União, proteger e respeitar todos os seus bens.

$27 \quad \mathrm{O}$ art. 68 da ADCT reconhece a propriedade definitiva, aos remanescentes das comunidades quilombolas, devendo o Estado emitir títulos. 
A QUESTÃO AGRÁRIA NO BRASIL: CAMPESINATO, AGRICULTURA FAMILIAR E AGRONEGÓCIO

Outras populações tradicionais, como ribeirinhos, castanheiros e quebradeiras de coco babaçu ${ }^{28}$, puderam se valer de instrumentos de regularização fundiária específicos, como os projetos de assentamento agroextrativistas. $\mathrm{Na}$ prática, cada estrutura burocrática, acabou por criar processos administrativos de territorialização, entretanto a diversidade de categorias fundiárias, não pode introduzir restrições de direitos, criando situações em que uma determinada prática de atividade agroextrativista, seja permitida em uma unidade fundiária e em outra não, sendo do mesmo grupo social (BOCKER, 2010).

Para solucionar tal problemática, foi-se criado a IN n 9/2020-FUNAI, com o intuito de corrigir as diversas inconstitucionalidades, detectadas em estudos pela Procuradoria Federal Especializada em Matéria Indígena, onde a mesma explica, por meio de parecer técnico (Parecer n. 00007/2020/COAF/PFE/PFE-FUNAI/ PGF/AGU) que, há IN n 3/2012 da FUNAI, revogada pela IN nº 9/2020, permitia que antes do Decreto Homologatório Presidencial, fosse possível ao Estado, interferir por prazo indeterminado em face de procedimentos demarcatórios em curso. Tendo em vista, que o Direito Fundamental a posse e propriedade está positivado no art. $5^{\circ}$, inciso XXII da CF/88. Propriedades privadas incidentes em terras sob estudo de identificação e delimitação (fase do rito demarcatório que pode durar décadas, eis que normalmente judicializada), passavam a ser inscritas em bancos de dados públicos restritivos da posse (SIGEF), o que impedia a emissão de atestados administrativos aos respectivos proprietários, impedindo o usufruto pleno sobre as glebas.

Essa inconstitucionalidade é reconhecida pela MS 8032/DF-STJ, por meio da Relatora Ministra Eliana Calmon, publicada em 02/12/2002, onde a mesma aduz que: "A identificação das áreas de ocupação tradicionalmente indígena depende de demarcação que compete à União, conforme dispõe o próprio art. 231, caput, da Constituição da República. Não basta o laudo antropológico que, em-

28 A Lei 231/2007 proíbe a derrubada de palmeiras de babaçu nos Estados do Maranhão, Piauí, Tocantins, Pará, Goiás e Mato Grosso, criando regras para a exploração da espécie nativa. 
bora traduza estudo científico e detalhado, não é apto a gerar, por si só, efeitos demarcatórios, que dependem de processo administrativo previsto no Decreto 1.775, de 08 de janeiro de 1996, que qualifica tal estudo apenas como fase inicial. Ausente, no caso, demarcação advinda de procedimento regular. Imperiosa a observância dos procedimentos normativos para que ninguém seja privado de seus bens sem o devido processo legal (art. $5^{\circ}$, inc. LIV, CR), impondo-se o resguardo da segurança jurídica". Por outro lado, o TRF da $3^{a}$ Região, por meio de Al 0002512-14.2012.4.03.0000/MS, Relatora Desembargadora Federal Ana Pezarini, publicada em 08/05//2013, aduz que: "O Decreto $n^{0}$ 1.775/96 estabelece que a demarcação não traz nenhuma restrição aos proprietários, que poderão continuar utilizando suas terras para fins produtivos, sem qualquer prejuízo material ou de outra ordem e que esta deve ser baseada e fundamentada em trabaIhos antropológicos de identificação".

\section{EFEITOS JURÍDICOS DA POSSE AGROECOLÓGICA}

O principal efeito da posse agroecológica, diz a respeito do poder de invocação dos interditos possessórios em sua defesa ${ }^{29}$. Neste caso o possuidor pode recorrer ao Poder Judiciário a fim de assegurar o seu direito a terra e ao uso dos recursos naturais ${ }^{30}$. Uma segunda possibilidade ocorre quando o próprio possuidor realiza a proteção pessoal da posse, mas a reação do possuidor tem que ser efetivada através do uso dos meios necessários e proporcionais à agressão ${ }^{31}$.

Como se trata de posse agroecológica, ou seja, um apossamento que congrega posses familiares e áreas de uso comum, não é necessário que o grupo social como um todo tenha a posse esbulhada ou turbada para que ocorra a sua

29 A posse agrária é mencionada no art. 102 do Estatuto da Terra, no art. $3^{\circ}$, inciso $\mathrm{VI}$ do Código Florestal e no art. 184 a 191 da Constituição Federal de 1988. Já a posse civil é mencionada nos arts. 1.091 a 1.196 do Código Civil e ainda, nos arts. 554 a 556 do Código de Processo Civil.

30 A proteção da posse está prevista nos arts. 1.210 e 1.211 do Código Civil, em quanto que as ações possessórias estão regulamentadas nos arts. 554 a 568 do Código de Processo Civil.

$31 \quad \mathrm{O} \S 1^{\circ}$ do art. 1.210 do Código Civil, assegura ao possuidor turbado ou esbulhado de manter-se ou de restituir a posse por sua própria força. 
proteção. Basta que uma das posses familiares e/ou a área de uso comum seja agredida para que um ou mais membros do grupo social saiam em sua defesa, seja pela via judicial, seja pessoalmente (MARQUES, 2017).

A transmissão da posse agroecológica acontece com as mesmas características com que foi adquirida, desta forma, se um dos membros do grupo social pretende vender a sua posse familiar, o mesmo só poderá realizá-la com a parte que demandou seu trabalho pessoal ou familiar, ou seja, a casa, a roça, a capoeira, a estrada de seringa ou castanha.

Ha área de uso comum, não pode ser adquirida pela compra, doação ou por herança, sendo comum, ela é indisponível e indivisível, logo o que um ou mais membros do grupo podem vender é a sua posse familiar, pois a posse agroecológica é composta pelo conjunto de famílias de camponeses e a área comum, sendo assim, o que é herdado na posse agroecológica é a parte do apossamento familiar, o mesmo ocorre no caso de venda, ou seja, todas as famílias que compõem a posse agroecológica têm direito de receber os frutos produzidos (ROCHA, 2019). Contudo, é importante mencionar, que deve ser respeitando, ainda a deliberação dos mesmos, em consonância com o princípio da autonomia, previsto no art. $7^{\circ}$ da Convenção 169 da OIT.

\section{DIREITO A REGULARIZAÇÃO FUNDIÁRIA DE TERRAS DEVOLUTAS}

O Estado brasileiro admite a posse de particulares em terras devolutas, dando preferência aos posseiros familiares para adquiri-las, respeitando os parâmetros legais. Entretanto, o art. 13 da Lei $n^{\circ}$ 8.629/93, determinam que as terras rurais de domínio da União, dos Estados e dos Municípios, sejam destinadas preferencialmente à execução de planos de reforma agrária. A partir dessas determinações, os critérios para destinação de terra, para a ocupação familiar se dá de forma individual ou coletiva. Os arts. 24 e 99 do Estatuto da Terra, afirmam que: "deve ser respeitada a ocupação de terras devolutas federais, manifestada em cultura efetiva e moradia habitual". 
Logo, é condição sine qua non que a área esteja sendo ocupada, pois o art. 26 do mesmo diploma legal orienta que: "o imóvel rural não é divisível em áreas de dimensão inferior à constitutiva do módulo de propriedade rural", desta forma, terá preferência para adquirir um lote da dimensão do módulo de propriedade rural, aquele que ocupar a terra devoluta por pelo menos um ano, esta é a redação do presente art. 97, inciso II do Estatuto da Terra, onde este dispositivo deve ser aplicado, quando se tratar de ocupação familiar individual, pois a posse coletiva não está ligada a uma relação temporal. As terras para proteção ambiental possuem uma sistemática própria, prevista na Lei de $n^{\circ}$ 9.985/2000, determinando que quando houver sobreposição de interesses, a destinação ambiental acaba se sobrepondo às demais destinações agrárias de acordo com o presente art. 225, § $5^{\circ}$ da CF/88 (ROCHA, 2019).

É neste sentido, que o Tribunal de Justiça do Rio Grande do Sul, vem entendido de forma célere, por meio da Apelação Civil 70081566853/RS do Relator Gelson Rolim Stocker, julgado em 22/08/2019, pela $17^{\text {a }}$ Câmara Cível e Publicado em 09/09/2019, vejamos a ementa do egrégio TJRS:

APELAÇÃO CÍVEL. USUCAPIÃO (BENS IMÓVEIS). USUCAPIÃO EXTRAORDINÁRIO. CONTESTAÇÃO DO ESTADO DO RIO GRANDE DO SUL. TERRAS DEVOLUTAS. COMPROVAÇÃO DA POSSE QUALIFICADA EXERCIDA PELA PARTE AUTORA DURANTE VINTE ANOS. NÃO DEMONSTRAÇÃO DE FORMA SATISFATÓRIA DA CONDIÇÃO DE TERRA DEVOLUTA. SENTENÇA DE PROCEDÊNCIA MANTIDA. Trata-se de ação de usucapião extraordinário em que comprova a parte autora que ocupa a área de terras rurais há vinte anos, sem qualquer oposição ou interrupção, tendo estabelecido residência e realizado plantações e criação de animais no local- Estado do Rio Grande do Sul que pretende a declaração de insuscetibilidade de prescrição aquisitiva, por ser considerada terra devoluta, no entanto, não logra êxito em comprovar tal situação, encargo probatório que Ihe compete - Conjunto de provas que demonstra a posse qualificada pela parte autora, ao longo de mais de duas décadas, ao passo que o Estado do Rio Grande do Sul não comprova a caracterização da área como devoluta, não bastando a juntada de documentação unilateral, sem qualquer registro - A inexistência de matrícula registral do imóvel não o torna, por si só, terra devoluta, especialmente quando comprovada a posse qualificada por particular, necessitando de procedimento discriminatório, extrajudicial ou judicial, realizado pelo ente Público que assim qualifique a área de terras, o que 
A QUESTÃO AGRÁRIA NO BRASIL: CAMPESINATO, AGRICULTURA FAMILIAR E AGRONEGÓCIO

inexiste no caso em comento. APELAÇÃO DESPROVIDA. UNÂNIME. (TJ-RS - AC: 70081566853 RS, Relator: Gelson Rolim Stocker, Data de Julgamento: 22/08/2019, Décima Sétima Câmara Cível, Data de Publicação: 09/09/2019).

Contudo, se houver conflito de interesses em uma mesma área, os que têm direito de preferência na regularização fundiária em terras públicas, conforme prevê os princípios e normas constitucionais. Em primeiro lugar, as posses tradicionalmente ocupadas pelos índios e pelas comunidades quilombolas. Em segundo lugar, as áreas necessárias à proteção dos ecossistemas naturais e as ocupadas pelas populações tradicionais. Em terceiro lugar, as terras destinadas à reforma agrária e propriedade familiar e por último, as terras de atividades agroambientais, pecuária e extrativismo para imóveis (ROCHA, 2019).

\section{CONSIDERAÇÕES FINAIS}

As ocupações de terras devolutas foram historicamente reconhecidas como posse, mas no transcorrer dos séculos esse reconhecimento foi questionado e restringido, seja pela previsão normativa ou pelo entendimento doutrinário e jurisprudencial.

Desta forma, não prospera a tese de que com a vedação à usucapião, houve a proibição da posse de terras públicas, uma vez que, este reconhecimento pode ocorrer com ou sem a concordância do Poder Público. Nessa perspectiva, os povos indígenas, quilombolas e populações tradicionais agroextrativistas, possuem o reconhecimento da posse independentemente da concordância do Poder Público, pois para estes sujeitos a recusa do Estado em reconhecer a posse ou a propriedade pode ser suprida pelo Poder Judiciário, mesmo diante da oposição do ente público.

No caso de interesse privado em conflito com o interesse público, onde ambos pertencerem ao amplo rol de direitos fundamentais, a Administração Pública deve apenas se sobrepor ao interesse privado se houver a satisfação do interesse público primário e secundário, que como visto são aqueles direcionado 
para a satisfação dos interesses da coletividade, pois a partir da interpretação da Constituição de forma sistêmica, nem os interesses públicos são superiores aos privados, tão pouco os privados são superiores aos públicos.

Contudo, o uso da analogia é fundamental para dar tratamento igualitário a casos semelhantes, sob o ponto de vista de seus efeitos jurídicos. Por isso, as coincidências dos casos proferidos pelo TRF4a em seu Agravo de Instrumento 200804.00.010160-5/PR, que reconheceu a aplicabilidade da convenção 169 da OIT para as comunidades quilombolas e a Apelação Cível 70081566853/RS da $17^{\text {a }}$ Câmara Cível, sobre usucapião de terras devolutas, proferida pelo TJRS, demonstra a possibilidade de aplicação para as comunidades agroextrativistas, visto que não há norma regulamentadora, cabendo ao legislador interprete aplicar o presente art. $4^{\circ}$ da LINDB por analogia, buscando o preenchimento de lacunas normativas.

\section{REFERÊNCIAS}

ARAGÃO, Alexandre Santos de. Direito dos Serviços Públicos. $4^{\mathrm{a}}$ ed. Belo Horizonte: Fórum, 2017, p.82.

ALESSI, Renato. Sistema Istituzionale Del Diritto Amministrativo Italiano. Milano: Giuffrè, 1953, p.151.

ALEXY, Robert. Direitos Fundamentais, Balanceamento e Racionalidade. Tradução de Menelick de Carvalho Netto. Faculdade de Direito da Universidade Federal de Minas Gerais. Ratio Juris. Vol. 16, n. 2, junho de 2003. Disponível em: $<$ https://edisciplinas.usp.br/pluginfile.php/4191688/mod_resource/content/1/Leitura\%200brigat\%C3\%B3ria\%20Semin \%C3\%A1rio\%2007\%20\%28texto1\%29. pdf>. Acesso em: 03 de maio 2019.

BARROSO, Luís Roberto. O Estado contemporâneo, os direitos fundamentais e a definição da supremacia do interesse público. In: SARMENTO, Daniel (Org.). Interesses públicos versus interesses privados: desconstruindo o princípio da supremacia do interesse público. $2^{a}$ Tiragem. Rio de Janeiro: Lumen Juris, 2007. p.13. 
BARRETO, Andreia Macedo. Território de Águas na Amazônia: Ribeirinhos e o Direito à Propriedade Coletiva da Terra. $1^{\text {a }}$ ed. Curitiba: Juruá, 2019, p. 29.

BENATTI, José Heder. Estrutura Agroambiental e seu Regime Jurídico. XIV Congresso Nacional do Conselho Nacional de Pesquisa e Pós-Graduação em Direito (CONPEDI). Disponível em: <https://www.researchgate.net/publication/331207981_ESTRUTURA_DA_PROPRIEDADE_AGROAMBIENTAL_E_ SEU_REGIME_JURIDICO>. Acesso em: 05 de abril de 2019.

BENATTI, José Heder. Direito de propriedade e proteção ambiental no Brasil: Apropriação e uso dos recursos naturais. Tese de Doutorado do Núcleo de Altos Estudos Amazônicos da Universidade Federal do Pará. Belém do Pará, 2003. Disponível em: <https://www.cjf.jus.br/ojs2/index.php/revcej/article/ view/126/169?rewrite491=1\&reas>. Acesso em: 04 de maio de 2019.

BECKER, Bertha Koiffmann. Novas territorialidades na Amazônia: desafio às políticas públicas. Boletim do Museu Paraense Emílio Goeldi; Ciências Humanas, Belém, v. 5, 1, jan. - abr. de 2010; Disponível em: <https://www.scielo.br/pdf/ bgoeldi/v5n1/a03v5n1.pdf>. Acesso em: 06 de agosto de 2019.

CANOTILHO, José Joaquim Gomes. Direito constitucional e teoria da constituição. $7^{a}$ ed. Rio de Janeiro: Almeida, 2003, p. 327.

DI PIETRO, Maria Sylvia Zanella. Direito Administrativo. $33^{a}$ ed. São Paulo: Forense. 2020, p. 223.

MENDES, Gilmar Ferreira. BRANCO, Paulo Gustavo Gonet. Curso de Direito Constitucional. $15^{\mathrm{a}}$ ed. São Paulo: Saraiva, 2020, p. 426.

GABARDO, Emerson. Princípio da Supremacia do Interesse Público sobre o Interesse Privado como Fundamento do Direito Administrativo Social. Revista de Investigações Constitucionais. Vol. 4, n.2, maio/agosto de 2017. Disponível em: <https://www.researchgate.net/publication/319257716_O_principio_da_supremacia_do_interesse_publico_sobre_o_interesse_privado_como_fundamento_do_Direito_Administrativo_Social>.Acesso em: 02 de março de 2019.

ROCHA, Ibraim. TRECCANI, Girolamo Domenico. BENATTI, José Heder. HABER, Lilian Mendes. CHAVES, Rogério Arthur Friza. Manual de Direito Agrário-Constitucional: Lições de Direito Agroambiental. $3^{a}$ ed. Belo Horizonte: Fórum, 2019, p. 161 e p. 257. 
HACHEM, Daniel Wunder. A discricionariedade administrativa entre as dimensões objetiva e subjetiva dos direitos fundamentais sociais. Direitos Fundamentais \& Justiça. Belo Horizonte. ano 10 n. 35, p. 313-343. Jul./dez. 2016. Disponível em: <http://www.danielwunderhachem.com.br/artigos_detail.php?id_ artigo=29>. Acesso em: 05 de julho de 2019.

OLIVEIRA, Rafael Carvalho Rezende. Novo perfil da Regulação Estatal: Administração Pública de Resultado e Análise de Impacto Regulatório. $1^{a}$ ed. São Paulo: Forense, 2015, p. 203.

SCHIER, Paulo Ricardo. Ensaio sobre a supremacia do interesse público sobre o privado e o regime jurídico dos direitos fundamentais. In: SARMENTO, Daniel (Org.). Interesses públicos versus interesses privados: desconstruindo o princípio da supremacia do interesse público. $2^{\mathrm{a}}$ Tiragem. Rio de Janeiro: Lumen Juris, 2007.

JÚNIOR, Cláudio Grande. Usucapião sobre Terras Públicas e Devolutas. $1^{\text {a }}$ ed. Rio de Janeiro: Lumen Juris, 2020.

TARTUCE, Flávio. Direito Civil - Direito das Coisas - Vol. 4. 12 ed. São Paulo: Forense. 2020. 


\section{SOBRE OS ORGANIZADORES}

\section{ADILSON TADEU BASQUEROTE}

Doutor em Geografia pela Universidade Federal de Santa Catarina (UFSC/2020), com estágio de Doutoramento Sanduíche no Instituto de Ordenamento do Território da Universidade de Lisboa (IGOT/UL). Mestre em Planejamento Territorial e Desenvolvimento Socioambiental pela Universidade do Estado de Santa Catarina (UDESC) (2015). Graduado em Pedagogia pelo Centro Universitário Internacional (2017) e em Estudos Sociais- Geografia pela Universidade de Santa Cruz do Sul (2004). Atualmente é professor no Centro Universitário para o Desenvolvimento do Alto Vale do Itajaí (UNIDAVI). Compõe o corpo editorial, científico e de pareceristas de revistas científicas na área de Ensino e de Educação Geográfica. Possui experiência na Educação Geográfica, dedicando-se em especial ao uso das TIC no Ensino e na aprendizagem, Ensino e Aprendizagem, Recursos didáticos. Paralelamente, pesquisa os seguintes temas: Agroecologia, Agricultura Familiar, Gênero em contextos rurais, Associações agrícolas familiares e Segurança alimentar.

\section{$\triangle N E$ CARINE MEURER}

Possui graduação em Pedagogia pela Faculdade de Filosofia Ciências e Letras Dom Bosco (1987), mestrado em Educação Nas Ciências pela Universidade Regional do Noroeste do Estado do Rio Grande do Sul (1997) e doutorado em Educação pela Universidade Federal da Bahia (2003). É professora da Universidade Federal de Santa Maria, Centro de Educação, Departamento de Fundamentos da Educação para as licenciaturas da UFSM e do Programa de Pós-Graduação em Geografia. Foi vicediretora do centro de educação da Universidade Federal de Santa Maria (2009-2017); Diretora do Centro de Educação (2017-2021). Tem experiência na área de Educação, com ênfase em Educação e Movimentos Sociais, atuando principalmente nos seguintes temas: educação do campo, educação, projeto político-pedagógico da escola, formação de professores e Base Nacional Comum Curricular (BNCC). 


\section{EDUARDO PIMENTEL MENEZES}

Licenciado em Geografia pela Universidade Federal Fluminense, Bacharel em Geografia pela Universidade Federal Fluminense, Especialista em Planejamento e Técnicas de Ensino pela UNIGRANRIO, Mestre em Educação pela Universidade Salgado de Oliveira, Mestre em Geografia pela Universidade Federal Fluminense, Doutor em Educação pela Universidade Federal Fluminense, Doutor em Geografia pela Universidade Federal Fluminense, Pós doutor em Políticas Públicas pela Universidade Federal Fluminense, Consultor Institucional do MEC, Consultor ad hoc da Revista Brasileira de Estudos Pedagógicos (Rbep), Parecerista da Revista Brasileira de Aprendizagem Aberta e a Distância (RBAAD), Integrante do Conselho Editorial Permanente e do Conselho Científico Permanente da Editora CRV, Professor Adjunto da UERJ (Universidade Estadual do Rio de Janeiro) e Professor Adjunto do curso de Geografia da PUC-RJ. 


\section{SOBRE AS AUTORAS E OS AUTORES}

\section{Antonio Eusébio de Sousa}

Professor de Geografia da rede pública municipal de Picos - PI e da Secretaria Estadual de Educação do Piauí - SEDUC - PI. Mestre em Geografia pela UNESP - Programa Desenvolvimento Territorial na América Latina e Caribe. Doutorando em Geografia pela UNESP - Campus de Presidente Prudente. E-mail: sousa.eusebio1@gmail.com.

\section{Antonio Nivaldo Hespanhol}

Professor do Departamento de Geografia e do Programa de Pós Graduação em Geografia da Universidade Estadual Paulista (UNESP), Faculdade de Ciências e Tecnologia, Campus de Presidente Prudente - SP.

E-mail: nivaldo.hespanhol@unesp.br.

\section{Bruno Andrade Ribeiro}

Doutorando do Programa de Pós-graduação em Geografia da Universidade Federal de Sergipe (PPGEO//UFS). Mestre em Geografia (2020); pesquisador do Grupo de Pesquisa Relação Sociedade Natureza e Produção do Espaço Geográfico - PROGEO e do Laboratório de Estudos Territoriais - LATER. Membro associado da Associação de Geógrafos Brasileiros (AGB - Seção Aracaju).

E-mail: ribeiro.pensador@gmail.com

Lattes: http://lattes.cnpq.br/3068631627993366

Orcid: https://orcid.org/0000-0002-7787-7682

\section{Geovânio Silva Santos}

Graduando do Curso de Licenciatura em Geografia pela Universidade Federal de Sergipe, Campus Prof. Alberto Carvalho em Itabaiana/Sergipe. Bolsista no Programa de Educação Tutorial - PET sob tutoria do Prof. Dr. José Hunaldo Lima. Integrante do Grupo de Pesquisa Relação Sociedade- Natureza e Produção do Espaço Geográfico (PROGEO/UFS/CNPq).

E-mail: geovaniogeoufs@gmail.com

\section{Hádrian George da Rocha Santos}

Graduando em Engenharia Mecânica pela Universidade Federal de Sergipe. Integrante do Núcleo de Tecnologia Social do Departamento de Engenharia Mecânica/NTS/UFS. Universidade Federal de Sergipe.

Email: hadrianrocha@hotmail.com 


\section{Handresha da Rocha Santos}

Graduada em Geografia pela Universidade Federal de Sergipe, Especialista em Gestão Ambiental, Mestre em Geografia pelo Programa de Pós-Graduação em Geografia da Universidade Federal de Sergipe. Membro do Grupo de Pesquisa sobre Transformações no Mundo Rural.

E-mail: handresharocha@yahoo.com.br

\section{Josefa de Lisboa Santos}

Professora dos cursos de Graduação e Pós-Graduação em Geografia da Universidade Federal de Sergipe e líder do Grupo de Pesquisa Relação Sociedade Natureza e Produção do Espaço Geográfico - PROGEO e do Laboratório de Estudos Territoriais - LATER.

E-mail: josefalisufs@gmail.com

Lattes: http://lattes.cnpq.br/7908218920423607

Orcid: https://orcid.org/0000-0002-5862-4428

\section{João Santos Nahum}

Doutor em geografia UNESP-Rio Claro, Docente da FGC/PPGEO-UFPA. Coordenador do Grupo de Pesquisa GDEA - Dinâmicas Territoriais do Espaço Agrário na Amazônia e do Observatório do dendê.

E-mail: prof.joaonahum@gmail.com.

ORcid: https://orcid.org/0000-0001-7791-9240.

\section{Leonardo de Sousa Santos}

Universidade Federal do Pará (UFPA): Doutor em Geografia (UFPA). Pesquisador do Grupo de Pesquisa GDEA - Dinâmicas Territoriais do Espaço Agrário na Amazônia e Secretário do Observatório do dendê.

ORcid: https://orcid.org/0000-0003-1912-7100.

E-mail: leonardodrgeo@gmail.com.

\section{Larissa Oliveira Dionisio}

Mestre em Geografia pela Universidade Estadual Paulista (UNESP), Faculdade de Ciências e Tecnologia, Campus de Presidente Prudente - SP.

E-mail:1_ltc@hotmail.com 


\section{Mílvio da Silva Ribeiro}

Doutorando do Curso de Pós-Graduação em Geografia-PPGEO da Universidade Federal do Pará - UFPA. E-mail: milvio.geo@gmail.com.

\section{Mara Íris Barreto Lima}

Mestranda do Programa de Pós-graduação em Geografia da Universidade Federal de Sergipe (PPGEO/UFS/CAPES), sob orientação da Profa. Dra. Josefa de Lisboa Santos. Pesquisadora do Grupo de Pesquisa Relação Sociedade Natureza e Produção do Espaço Geográfico - PROGEO/UFS/CNPq e do Laboratório de Estudos Territoriais - LATER.

E-mail: mara21iris@gmail.com

\section{Nathalie Vieira Lucion}

Graduanda em Geografia pela Universidade Federal do Paraná.

E-mail: nathiluci@gmail.com.

\section{Rodrigo Simão Camacho}

Possui Pós-doutorado em Geografia. Docente no Curso de Graduação de Licenciatura em Educação do Campo (LEDUC) e no Programa de Pós-Graduação em Educação e Territorialidade (PPGET), Faculdade Intercultural Indígena (FAIND/UFGD). Nos Programas de Pós-Graduação em Geografia na UFGD e na UFMS. É Coordenador do Grupo de Pesquisa do CNPq: Geografia, Educação do Campo e Questão Agrária (GeoEduQA) e membro da Rede DATALUTA. E-mail: rodrigocamacho@ufgd.edu.br.

\section{Tiago Barreto Lima}

Graduando do Curso de Licenciatura em Geografia pela Universidade Federal de Sergipe, Campus Prof. Alberto Carvalho em Itabaiana/Sergipe. Bolsista no Projeto de Monitoria das disciplinas Formação Territorial e Econômica do Brasil e, Produção e Organização do Espaço Mundial (DGEI/UFS), sob coordenação da Profa. Dra. Vanessa Dias de Oliveira. Integrante do Grupo de Pesquisa Relação Sociedade-Natureza e Produção do Espaço Geográfico (PROGEO/UFS/CNPq). Membro associado da Associação de Geógrafos Brasileiros - AGB: Seção Local Aracaju - SE.

E-mail: thiagobarreto824@gmail.com

Lattes: http://lattes.cnpq.br/7650511872154497

Orcid: https://orcid.org/0000-0003-1360-2302 


\section{Wellington Cesar Barbosa de Lira}

Professor universitário, geógrafo do INCRA SR(03)/PE, Me. em geografia pela UFPE.

E-mail: wellingtonlira@yahoo.com.br

Lattes: http://lattes.cnpq.br/2352186019081828

Linkedin: https://www.linkedin.com/in/wellington-lira-08137a57/

\section{Walder Araújo de Oliveira}

Graduado no Curso de Bacharelado em Direito pela Faculdade Estácio-Unidade de Castanhal-PA. Pós-Graduado no Curso de Especialização em Direito Administrativo pela Pontifícia Universidade Católica de Minas Gerais. Controlador Interno do Município de Santa Luzia do Pará.

E-mail: walder21araujo@gmail.com 
www.arcoeditores.com
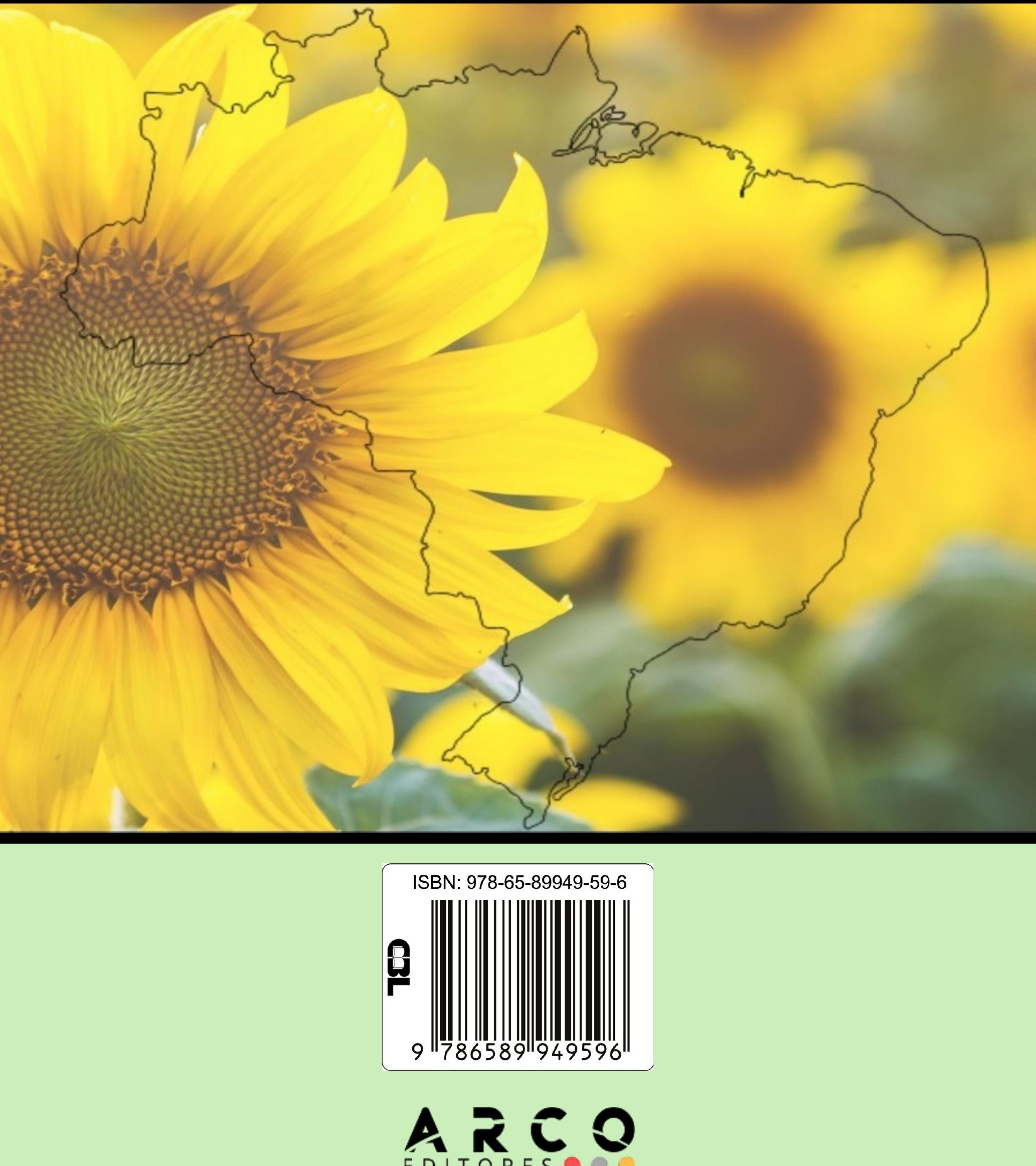